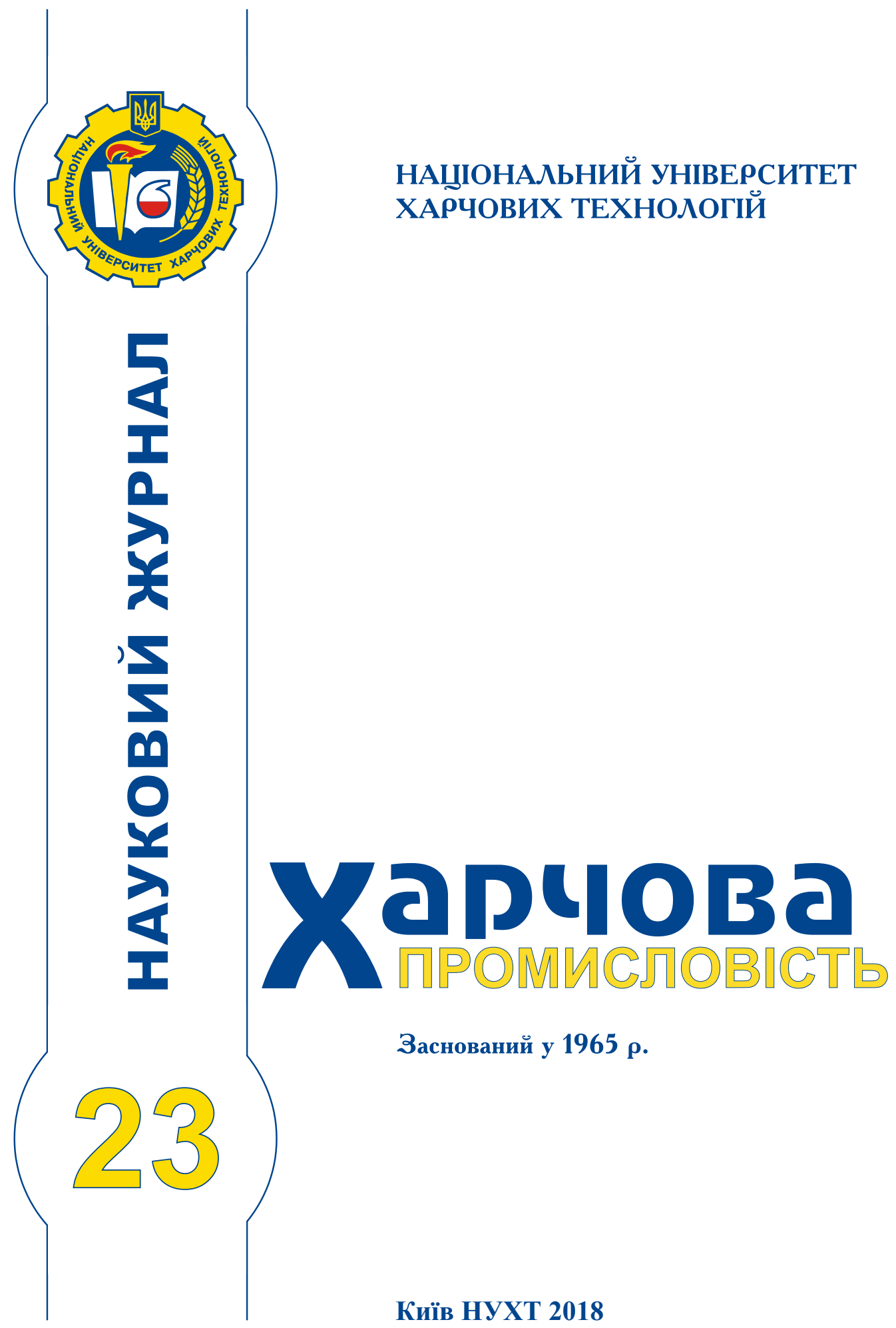


Results of research and development operations on technology of foodstuff, chemical, biochemical, microbiological processes, devices, the equipment, automation of food productions and economy of the food industry are provided.

The journal was designed for scientists, engineers and technical personnel of the food industry

Journal "Food Industry" is included into the list of professional editions of Ukraine of technical sciences (Decree of MES of Ukraine \# 241 from March 9, 2016), where the results of dissertations for scientific degrees of $\mathrm{PhD}$ and candidate of science can be published.

The Journal "Food Industry" is indexed by the following scientometric databases:

- Google Scholar

- Index Copernicus edition.

Publications are represented in authoring

\section{Editorial office address:}

National University of

Food Technologies

Volodymyrska str., 68,

01601 Kyiv, Ukraine

(044) 287-92-45, 287-94-21

E-mail: tmipt_xp@ukr.net

Recommended for publication by the

Academic Council of the National University of

Food Technologies.

Minutes of meeting № 12

from 21st of June, 2018
Висвітлені результати науково-дослідних робіт з технології харчових продуктів, хімічних, біохімічних, мікробіологічних процесів, апаратів, обладнання, автоматизації харчових виробництв та економіки харчової промисловості.

Розрахований на наукових та інженернотехнічних працівників харчової промисловості.

Журнал «Харчова промисловість» включено в перелік наукових фахових видань України 3 технічних наук (Наказ МОН України № 241 від 09.03.2016), у яких можуть публікуватися результати дисер-таційних робіт на здобуття наукових ступенів доктора i кандидата наук.

Журнал «Харчова промисловість» індексується такими наукометричними базами:

- Google Scholar

- Index Copernicus

Статті друкуються в авторській редакції.

\section{Адреса редакції:}

Національний університет харчових технологій вул. Володимирська, 68, м. Київ, 01601 (044) 287-92-45, 287-94-21 E-mail: tmipt_xp@ukr.net

Рекомендовано вченою радою Національного університету харчових технологій.

Протокол № 12 від 21 червня 2018 року 
Редакційна колегія

Склад редакційної колегії журналу «Харчова промисловість»

Головний редактор

Editor-in-Chief

Анатолій Соколенко

Anatoliy Sokolenko

д-р техн. наук, проф., Україна

Відповідальний секретар

Accountable secretary

Сергій Токарчук

Serhiy Tokarchuk

Члени редакційної колегії:

Іван Шило

Ivan Shylo

Станка Дамянова

Stanka Damyanova

Стефан Стефанова

Stefan Stefanov

Анатолій Ладанюк

Anatoly Ladanyuk

Олександр Серьогін

Oleksandr Ser'ohin

Тетяна Пирог

Tetyana Pyroh

Олександр Шевченко

Olexander Shevchenko

Лариса Арсеньсва

Larysa Arsen'yeva

Тамара Носенко

Tamara Nosenko

Віра Оболкіна

Vera Obolkina

Віктор Ємцев

Viktor Yemtsev

Віра Юрчак

Vira Yurchak

Людмила Пешук

Lyudmyla Peshuk

Віктор Доценко

Victor Dotsenko

Віталій Прибильський

Vitaliy Prybyl's'kyy

Галина Сімахіна

Halyna Simakhina

Олена Грабовська

Olena Hrabovs'ka

Олександр Гавва

Oleksandr Gavva

Микола Якимчук

Mykola Yakymchuk

канд. техн. наук, доц., Україна

$\mathrm{Ph}$. D. As., Prof., National University of Food Technologies, Ukraine

д-р техн. наук, проф., Білорусь

Ph. D. Hab., Prof., Belarusian State Agrarian Technical University, Republic of Belarus

д-р техн. наук, доц., Болгарія

DSc, Assoc. Prof., Razgrad Branch of the University of Ruse, Bulgaria

д-р инж., проф., Болгарія

DSc, Prof., University of Food Technologies — Plovdiv, Bulgaria

д-р техн. наук, проф., Україна

Ph. D. Hab., Prof., National University of Food Technologies, Ukraine

д-р техн. наук, проф., Україна

Ph. D. Hab., Prof., National University of Food Technologies, Ukraine

д-р біол. наук, проф., Україна

Ph. D. Hab., Prof., National University of Food Technologies, Ukraine

д-р техн. наук, проф., Україна

Ph. D. Hab., Prof., National University of Food Technologies, Ukraine

д-р техн. наук, проф., Україна

Ph. D. Hab., Prof., National University of Food Technologies, Ukraine

д-р техн. наук, доц., Україна

Ph. D. Hab., Prof., National University of Food Technologies, Ukraine

д-р техн. наук, Україна

Ph. D. Hab., Prof., National University of Food Technologies, Ukraine

д-р екон. наук, проф., Україна

Ph. D. Hab., Prof., National University of Food Technologies, Ukraine

д-р техн. наук, Україна

Ph. D. Hab., Prof., National University of Food Technologies, Ukraine

д-р с-г. наук, проф., Україна

Ph. D. Hab., Prof., National University of Food Technologies, Ukraine

д-р техн. наук, проф., Україна

Ph. D. Hab., Prof., National University of Food Technologies, Ukraine

д-р техн. наук, проф., Україна

Ph. D. Hab., Prof., National University of Food Technologies, Ukraine

д-р техн. наук, проф., Україна

Ph. D. Hab., Prof., National University of Food Technologies, Ukraine

д-р техн. наук, проф., Україна

Ph. D. Hab., Prof., National University of Food Technologies, Ukraine

д-р техн. наук, проф., Україна

Ph. D. Hab., Prof., National University of Food Technologies, Ukraine

д-р техн. наук, проф., Україна

Ph. D. Hab., Prof., National University of Food Technologies, Ukraine 
3MICT

\section{РОЗДІЛ 1. ТЕХНОЛОГІЯ}

Сировина та матеріали

Однорог М.Р., Полішук Г.С. Застосування концентрату сироваткових білків для стабілізації структури сметани

Сімахіна Г.О., Камінська С.В., Мартиненко T.A. Оцінка втрат клітинного соку та зміни органолептичних показників заморожених плодів при тривалому зберіганні і дефростації

Махинько В.М., Шаран А.В., Шаран Л.О., Черниш Л.М. Вплив ізолятів рослинних білків на клейковинний комплекс пшеничного тіста Ющенко Н.М., Кузьлик У.Г., Миколів І.М. Використання прянощів як джерела антоціанів

Технології: дослідження, застосування та впровадження

Бендерська О.В., Бессараб О.С. Дослідження жирокислотного складу томатного насіння Подковко О.А., Полішук Г.С. Дослідження технологічно-функціональних властивостей порошків із буряка

РОЗДІЛ 2. ПРОЦЕСИ ТА ОБЛАДНАННЯ

Процеси харчових виробництв

Дорохович В.В., Літвинчук С.I., Носенко В.С. Одержання безглютенових вафельних листів iз гречаного борошна шляхом мікрохвильового оброблення

Никитюк Т.В., Олішевський В.В., С.М. Бабко, Украйнеиь А.I., Башта А.В., Прокопюк О.М. Методика визначення структурно-механічних властивостей бурякової тканини

Бабанов І.Г., Михайлов В.М., Шевченко А.О., Михайлова С.B. Перспективи способу жарення кулінарних виробів з електроконтактним тепловим впливом

Дударєв I.М. Моделювання процесу змішування сипких матеріалів у гравітаційному змішувачі

Обладнання та устаткування Захаров В.В., Змієвський Ю.Г., Мирончук В.Г., Дзязько Ю.С. Розроблення схеми переробки нанофільтраційного пермеату молочної сироватки

Ощипок I.M. Застосування багатолезного інструменту для подрібнення заморожених м'ясних блоків

\section{Пакування: розробка, дослідження, переробка}

Пасічний B.M., Храпачов О.В., Маринін А.I., Святненко Р.С., Гередчук А.М. Пакування під вакуумом як спосіб подовження термінів зберігання охолодженого м'яса та напівфабрикатів 3 нього

Якимчук М.В., Костюк В.С. Іванова Л.І., Якимчук B.M. Дослідження раціональних

\section{CONTENTS}

\section{SECTION 1. TECHNOLOGY \\ Raw Materials and Materials}

6 Odnorog M., Polischuk G. Application of the synthesis protein concentrate as a stabilizer of the structure of sour cream

13 Simakhina G., Kamins'ka S., Martynenko T. Estimation of cellular juice losses and shifts of organoleptic indices in frozen fruit during their prolonged storage and defrostation

21 Makhynko V., Sharan A., Sharan L., Chernish L. Influence of vegetable protein isolates on gluten complex of wheat dough

27 Yushchenko N., Kuzmyk U., Mykoliv I. Use of spices as a source of anthocyanins

Technologies: Researches, Application and Introduction

32 Benderska O., Bessarab A. Research of fatty acids tomato seeds

39 Podkovko O., Polishchuk H. Investigation of technologically-functional properties of red beet powders

SECTION 2. PROCESSES AND EQUIPMENT Processes of Food Industries

48 Dorokhovych V., Litvynchuk S., Nosenko V. Obtaining of gluten free waffle sheets with buckwheat flour by microwave treatment

55 Nykytiuk T., Olishevskyi V., Babko E., Ukrainets A., Bashta A., Prokopiuk O. Methodology of the determining of structural and mechanical properties of sugar beet tissue

62 Babanov I., Mikhaylov V., Shevchenko A., Mikhaylova $S$. Perspective of roasting method of culinary products with electro-contact heat treatment

67 Dudarev I. Simulation of bulk materials mixing process in gravitational mixer

\section{Machinery and Equipment}

74 Zakharov V., Zmievskii Yu., Myronchuk V., Dzya$z k o Y u$. Development of a scheme for processing of nanofiltration permeate

81 Oshchypok I. Application of the manyblades tool for milling of frozen meat blocks

\section{Packing: Development, Researches, Processing}

88 Pasichnyi V., Khrapachov O., Marynin A., Svyatnenko R., Geredchuk A. Shelf life extension of chilled meat and semi-finished meat products by vacuum packaging

95 Yakymchuk M., Ivanova L., Kostyuk V., Yakymchuk V. Research of scientific rational 
характеристик шредера для подрібнення полімерних виробів

Кривопляс-Володіна Л.О. Обгрунтування вибору ежекторів для пакувального обладнання Горчакова О.М., Якимчук М.В. Дослідження пневматичних шлангових затворів у мехатронних системах дозування рідких харчових продуктів

Керування виробничими процесами

Киченько В.Д., Крищенко Д.О., Кучер А.Є. Дослідження поведінки брагоректифікаційної установки методами вейлет-аналізу Лобок О.П., Гончаренко Б.М., Сич М.А. Чисельне моделювання $d$-області стійкості дробових лінійних динамічних систем

\section{Енергетика та виробничі процеси}

Соколенко A.I., Васильківський К.В., Cтепанець О.I., Юхно М.I. Пропозиції до використання замкнутих енергоматеріальних контурів characteristics for the extraction of polymeric articles

102 Kryvoplias-Volodina L. Advantages in the choice of ejectors for packaging equipment

109 Gorchakova O., Iakymchuk M. Research of the pneumatic hose shutter in mechatronic systems of the dosage of liquid foodstuffs

\section{Control of Production Processes}

116 Kyshenko V., Kryschenko D., Kycher A. Research of behavior of bragorectifying installation by wavelet analysis methods

122 Lobok O., Goncharenko B., Sych M., Vihrova L. Numerical simulation of the $d$-domain of stability of linear dynamical systems with fractional order

\section{Power engineering and productions}

131 Sokolenko A., Vasylkivsky K., Stepanets O., Juhno M. Proposals for use of closed energymaterial contours 
УДК 637.146.3

\title{
APPLICATION OF THE SYNTHESIS PROTEIN CONCENTRATE AS A STABILIZER OF THE STRUCTURE OF SOUR CREAM
}

\author{
M. Odnorog, G. Polischuk \\ National University of Food Technologies
}

\begin{tabular}{|c|c|}
\hline & ABSTRACT \\
\hline $\begin{array}{l}\text { milk-protein concentrates, } \\
\text { serum proteins, } \\
\text { sour cream }\end{array}$ & $\begin{array}{l}\text { The article presents the results of the study of the functional } \\
\text { and technological properties of milk-protein concentrate in the } \\
\text { composition of sour cream. The object of the study is samples }\end{array}$ \\
\hline $\begin{array}{l}\quad \text { Article history: } \\
\text { Received 27.03.2018 } \\
\text { Received in revised form } \\
\text { 10.05.2018 } \\
\text { Accepted } 04.06 .2018\end{array}$ & $\begin{array}{l}\text { of sour cream enriched with serum protein concentrate, obtained } \\
\text { by ultrafiltration (KSB-UV). Technological efficiency of KSB- } \\
\text { UV in the composition of sour cream was determined by the } \\
\text { organoleptic and physico-chemical parameters (titrated and } \\
\text { active acidity, degree of syneresis, microstructure), and also by }\end{array}$ \\
\hline $\begin{array}{l}\text { Corresponding author: } \\
\text { marinaodnorog95@ } \\
\text { gmail.com }\end{array}$ & $\begin{array}{l}\text { the degree of influence on the course of lactic fermentation. The } \\
\text { main results of the work consist in the substantiation of the } \\
\text { rational content of KSB-UV in the composition of low-fat sour } \\
\text { cream }(0.6 \%) \text { on the basis of the analysis of the complex of } \\
\text { organoleptic and physico-chemical parameters of the finished } \\
\text { product, as well as in the explanation of the mechanism of } \\
\text { starch formation in the presence of serum proteins. It is proved } \\
\text { that protein concentrate due to effective water binding affects } \\
\text { the activity of lactic acidity in proportion to its content, which } \\
\text { makes it possible to regulate the acidity of low-fat sour cream. } \\
\text { KSB-UV promotes the formation of a tender and saturated fine- } \\
\text { dispersed damp clot, characterized by a lack of syneresis. It has } \\
\text { been established that in order to achieve the acidity of sour } \\
\text { cream with serum protein concentrate not lower than } 60^{\circ} \mathrm{T} \text {, the } \\
\text { duration of the fermentation should be extended to } 1.5 \text { hours, } \\
\text { compared with the quenching of cream without concentrate. } \\
\text { Based on the results of the study, basic recipes of sour cream } \\
\text { from KSB-UV were developed. Industry recommendations for } \\
\text { the introduction of a new type of product at dairy enterprises are } \\
\text { that sour cream of high nutritional value can be made in a reserve } \\
\text { way, pumped through pipelines without the risk of fracture of the } \\
\text { structure and packaged in all types of consumer packaging. }\end{array}$ \\
\hline
\end{tabular}

\section{ЗАСТОСУВАННЯ КОНЦЕНТРАТУ СИРОВАТКОВИХ БІЛКІВ ДЛЯ СТАБІЛІЗАЦІЇ СТРУКТУРИ СМЕТАНИ}

\author{
М.Р. Однорог \\ Г.Є. Поліщук, д-р техн. наук \\ Національний університет харчових технологій \\ У статті наведено результати дослідження функціонально-технологічних \\ властивостей молочно-білкового концентрату у складі сметани. Основні
}

(C) М.Р. Однорог, Г.Є. Поліщук, 2018 
результати дослідження полягають в обгрунтуванні раціонального вмісту КСБУФ у складі сметани з низьким вмістом жиру (0,6\%) на основі аналізу комплексу органолептичних і фрізико-хімічних показників готового продукту, а також у поясненні механізму структурування кисловершкових згустків за наявності сироваткових білків. Доведено, що білковий концентрат за рахунок ефективного зв'язування води впливає на активність молочнокислої мікрофрлори пропориійно його вмісту, що дає змогу регулювати кислотність низькожирної сметанної основи. КСБ-УФ сприяє утворенню ніжного та насиченого дрібнодиспергованою вологою згустка, який характеризується відсутністю синерезису. Встановлено, що для досягнення кислотності сквашених вершків із концентратом сироваткових білків не нижче $60^{\circ} \mathrm{T}$ тривалість сквашування слід подовжувати до 1,5 год., порівняно зі сквашуванням вершків без концентрату.

Ключові слова: молочно-білкові концентрати, сироваткові білки, сметана.

Постановка проблеми. Сметана $є$ традиційним слов'янським кисломолочним продуктом, який користується високим попитом в Україні. У той же час формування глянсуватої і густої, притаманної сметані консистенції для продукту низької жирності без застосування спеціальних заквасок і термостатного способу є доволі складним завданням. Для зміцнення кисломолочного сметанного згустку у складі сметанних виробів застосовують загущувачі рослинного і тваринного походження. Вченими доведено ефективність використання молочнобілкових концентратів для покращення структури та реологічних властивостей продуктів [1]. В Україні виготовляють біологічно повноцінні білкові концентрати (казеїнати, сухе знежирене молоко, концентрати сироваткових білків, одержані методом ультрафільтрації), які мають здатність до ефективного зв'язуваня вологи та зміцнення кисломолочного згустку [2]. Тому розробка нового виду низькожирної сметани 3 молочно-білковим концентратом $\epsilon$ перспективним напрямком наукового дослідження.

На сьогодні застосування саме концентратів сироваткових білків набуло широкої популярності.

Їх застосовують у технологіях:

- продуктів спеціального харчування (дитячого, лікувального, спортивного) для збагачення їх необхідними нутрієнтами;

- кондитерських продуктів, кетчупів, соусів, майонезу для формування густої консистенції, а також як натуральний емульгатор, дешевший за яєчний порошок;

- кисломолочних продуктів, морозива та багатьох інших продуктів як стабілізуючий інгредієнт, а також для збільшення виходу готового продукту при виробництві сиру і як структуроутворювач при виробництві плавлених сирів [3].

Концентрат сироваткових білків, виготовлений методом ультрафільтрації (КСБ-УФ), добре розчиняється у воді, містить більше, ніж $80 \%$ біологічно цінних сироваткових білків, має високі емульгуючі властивості тощо [4]. КСБ-УФ застосовують як білковий збагачувач для підвищення біологічної цінності молочних, м'ясних, кондитерських, хлібобулочних та інших продуктів. Також він може використовуватися як стабілізатор структури морозива, низькожирної сметани і кефіру, як емульгатор у складі харчових емульсій.

Якість концентратів сироваткових білків (змочуваність, розчинність, емульгуючі властивості тощо) визначається розмірами, формою і властивостями сухих часток. Вони залежать від якості вихідного інгредієнта, температури його розчинення, режимів отримання концентрату і сушіння отриманих розчинів, а також від умов і тривалості збереження готових продуктів [5]. 
Українські науковці провели змістовні дослідження і довели користь концентрату сироваткових білків, отриманого методом ультрафільтрації, порівняно 3 сухою підсирною сироваткою. Доведено, що за вмістом незамінних амінокислот концентрати сироваткових білків переважають біологічну цінність сухої підсирної сироватки. Так, біологічна цінність сухої молочної підсирної сироватки становить 34,51\%, КСБ-70 з підсирної сироватки - 49,6\%, КСБ-70 з казеїнової сироватки $-47,5 \%[6 ; 7]$.

Біологічна цінність концентратів сироваткових білків обумовлена високим вмістом незамінних амінокислот [8]. Тому доцільним $є$ застосування КСБ-УФ не тільки як функціонально-технологічного інгредієнта, але й як функціональнобіологічного.

Оскільки сучасні споживачі переходять на раціональне харчування, доцільним і перспективним $\epsilon$ виробництво низькожирних молочних продуктів зі стабільними фізико-хімічними й органолептичними властивостями та збагачених повноцінними харчовими нутрієнтами.

Отже, КСБ-УФ є повноцінним молочно-білковим концентратом, який володіє технологічно-функціональними властивостями і може бути застосований у складі більшості молочних продуктів, у тому числі сметани з низьким вмістом жиру.

Мета дослідження: наукове обгрунтування доцільності застосування концентрату сироваткових білків як функціонально-технологічного інгредієнта у складі сметани низької жирності.

Сметана, збагачена КСБ-УФ, за існуючою термінологією у сфері виробництва молочних продуктів може бути віднесена до сметани, а не до сметанного виробу, оскільки у її складі не застосовані інгредієнти немолочного походження.

Концентрат сироваткових білків може суттєво покращувати консистенцію, запобігати синерезису (відділенню сироватки), що дасть змогу виготовляти сметану низької жирності гарантовано високої якості більш економічно вигідним резервуарним способом.

Матеріали і методи. Дослідні зразки сметани з масовою часткою жиру $10 \%$ виготовляли 3 вмістом концентрату сироваткових білків (КСБ-УФ) в діапазоні від 0,4 до $0,8 \%$ та визначали їхні органолептичні та фізико-хімічні показники якості для встановлення раціонального вмісту у готовому продукті сироваткових білків як стабілізуючого ігредієнта.

Для проведення дослідження використовували таку сировину і матеріали: вершки 3 масовою часткою жиру $10 \%$, одержані сепаруванням молока-сировини, що відповідає вимогам ДСТУ 3662; концентрат сироваткових білків, виготовлений відповідно до ТУ У 15.5-35293993-002:2011 «Концентрати сироваткові білкові «КСБ-УФ». Технічні умови»; заквашувальний препарат (Сметана «Vivo»), виготовлений за ТУ У 15.5-3060300036-001:2009 «Закваски бактеріальні «Vivo». Технічні умови»

Відбір проб і підготовку їх до аналізу здійснювали відповідно до ДСТУ ISO 707:2002; масову частку жиру — згідно з ГОСТ 5867-90; загальний вміст сухих речовин - за ДСТУ ISO 3728:2005; органолептичну оцінку готового продукту за ГОСТ 28283-95; густину - за ГОСТ 3625-92; титровану кислотність - за ГОСТ 3624-92; температуру сумішей — за ГОСТ 3622-68.

Органолептичні показники сметани визначали за 10-бальною шкалою, відповідно до вимог ДСТУ 4418:2005 «Сметана. Загальні технічні умови». 
Синерезис кисломолочних згустків визначали методом центрифужних пробірок за об'ємом сироватки, що відділяється під час центрифугування 3 проби об'ємом $10 \mathrm{~cm}^{3}$ упродовж 10 хв за частоти обертів $1000 \mathrm{xB}^{-1}$.

Мікроструктуру кисломолочних згустків вивчали мікроскопіюванням препаратів за допомогою світлового мікроскопа за збільшення $4 \times 15$ та 10×15.

Результати досліджень. На першому етапі наукового дослідження вивчали вплив КСБ-УФ на динаміку процесу сквашування вершків 3 масовою часткою жиру $10 \%$ та сенсорні характеристики сметани.

Білковий концентрат попередньо розчиняли у вершках жирністю $10 \%$ за гідромодуля $1: 10$ при початковій температурі $40^{\circ} \mathrm{C}$ з витримуванням впродовж $30-40$ хв для попереднього набухання 3 подальшою тепловою обробкою при температурі $85-90^{\circ} \mathrm{C}$ впродовж $2-3$ хв для забезпечення мікробіологічної чистоти та ефективного розчинення концентрату. Розчини фільтрували, охолоджували та вносили під час перемішування до пастеризованих і охолоджених до температури $\left(25-28^{\circ} \mathrm{C}\right)$ вершків після заквашування. Досліджували динаміку процесу сквашування за показником титрованої кислотності (рис. 1).

Відповідно до результатів дослідження встановлено, що концентрати сироваткових білків за рахунок ефективного зв'язування води впливають на активність молочнокислої мікрофлори пропорційно їх вмісту, що дає змогу регулювати кислотність низькожирної сметанної основи. Це $є$ важливим чинником, оскільки саме сметана з низьким вмістом жиру найчастіше має ваду - надмірна кислотність.

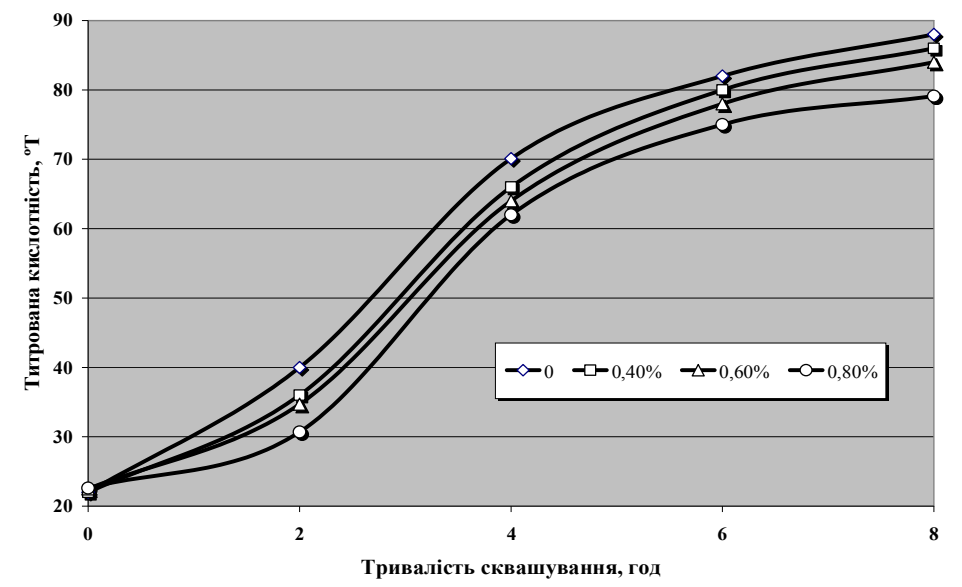

Рис. 1. Динаміка зміни титрованої кислотності заквашених вершків 3 різним вмістом КСБ-УФ

Також виявлено можливість стабілізації кислотності готового продукту впродовж зберігання терміном до п'яти діб.

Найвища кислотність спостерігалася у контрольному зразку, а з підвищенням вмісту концентрату іiі заростання все більш уповільнювалося (рис. 2). Цей ефект також пояснюється тим, що молочно-білкові концентрати зв'язують вільну вологу і за рахунок цього швидкість зростання кислотності зменшується. Тому для досягнення мінімально необхідної кислотності $\left(60^{\circ} \mathrm{T}\right)$ тривалість сквашування $з$ підвищенням вмісту концентрату сироваткових білків від 0,4 до $0,8 \%$ слід подовжувати від 0,5 до 1,5 год. 


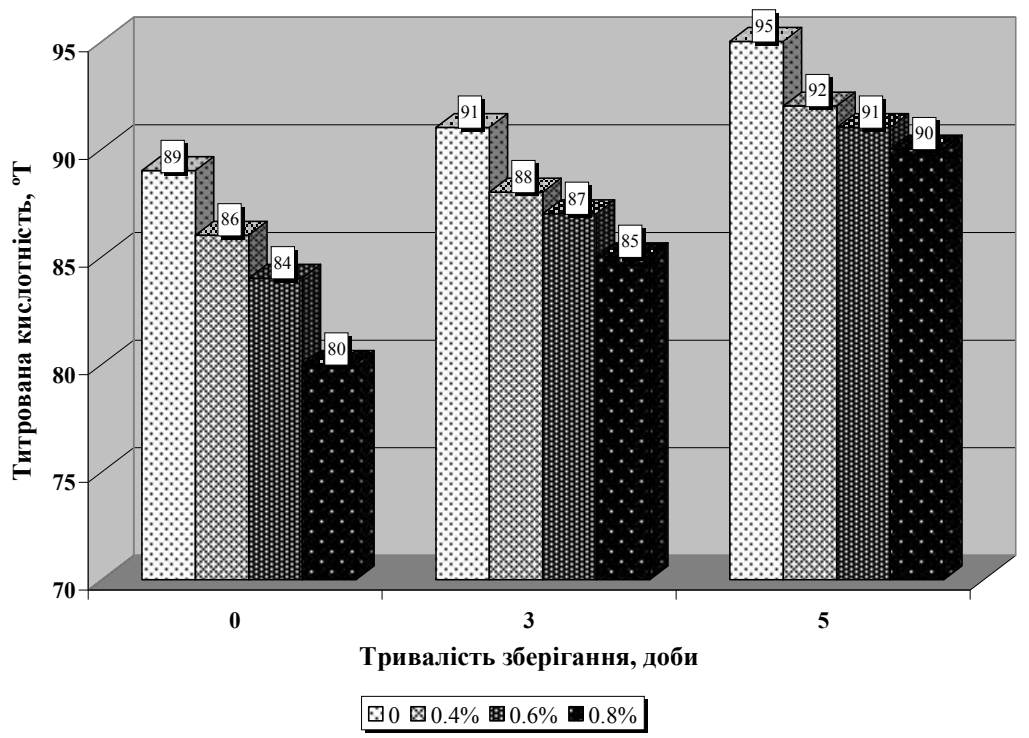

Рис. 2. Титрована кислотність зразків сметани з КСБ-УФ впродовж зберігання

У готових продуктах 3 концентратом сироваткових білків досліджено мікроструктуру, яку наведено на рис. 3.

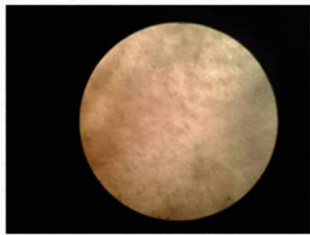

$4 \times 15$

Контроль

$10 \times 15$

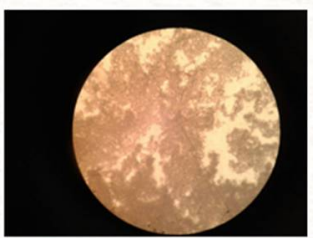

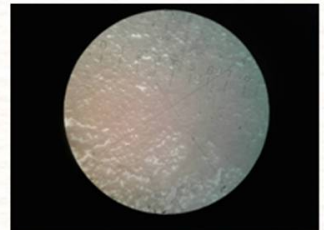

$4 \times 15$

$0,4 \%$

$10 \times 15$

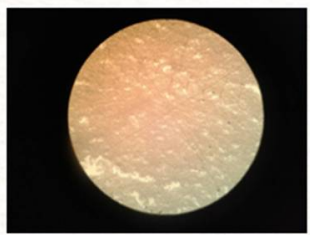

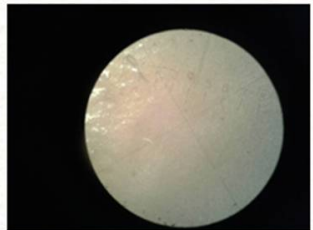

$4 \times 15$

$0,6 \%$

$10 \times 15$

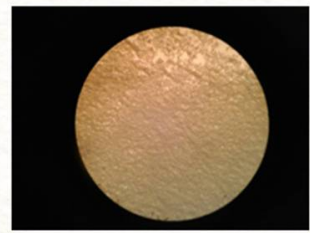

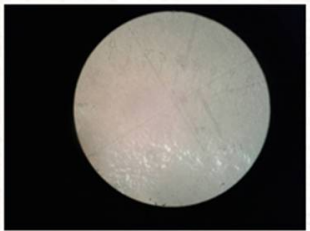

$4 \times 15$

$0,8 \%$

$10 \times 15$

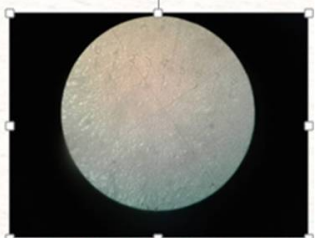

Рис. 3. Мікроструктура зразків сметани з КСБ-УФ

Порівняльний аналіз мікроструктури сметани вказує на поступове ущільнення їх структури із формуванням дрібних чарунок білкового гелю за підвищення вмісту КСБ-УФ. Концентрат сироваткових білків додатково зв'язує вільну вологу в готовому продукті. Це свідчить про те, що КСБ-УФ сприяє утворенню ніжного, насиченого дрібнодиспергованою вологою згустку.

Також слід відмітити, що за додавання до сметани концентратів сироваткових білків у встановленому діапазоні $(0,4 \ldots .0,8 \%)$ синерезис виявлено у зразку 3 концентрацією 0,4\%. Це вказує на те, що за вказаної кількості концентрат не повністю втримує вологу.

Органолептичні показники досліджуваних зразків наведено в таблиці. 
Таблиця. Органолептичні показники сметани з КСБ-УФ

\begin{tabular}{|c|c|c|c|c|}
\hline \multirow{2}{*}{ Показник } & \multicolumn{4}{|c|}{ Зразки сметанних виробів з КСБ-УФ } \\
\hline & Контроль & $0,4 \%$ & $0,6 \%$ & $0,8 \%$ \\
\hline \multirow[b]{2}{*}{ Смак і запах } & \multicolumn{4}{|c|}{$\begin{array}{l}\text { Чистий, кисломолочний, приємний, з ароматом властивим пастеризованому } \\
\text { продукту. }\end{array}$} \\
\hline & \multicolumn{2}{|c|}{ Без сторонніх присмаків і запахів } & $\begin{array}{c}\text { 3'являється ледь } \\
\text { відчутний } \\
\text { в'яжучий після } \\
\text { смак }\end{array}$ & $\begin{array}{c}\text { Яскраво виражений } \\
\text { в'яжучий після } \\
\text { смак }\end{array}$ \\
\hline \multirow{2}{*}{$\begin{array}{l}\text { Зовнішній } \\
\text { вигляд }\end{array}$} & \multicolumn{4}{|c|}{$\begin{array}{c}\text { Однорідна маса з глянцевою поверхнею, в’язка, наявність поодиноких } \\
\text { пухирців повітря. }\end{array}$} \\
\hline & Недостатньо густа & Недостатньо густа & Густа & $\begin{array}{l}\text { Найгустіша з усіх } \\
\text { зразків }\end{array}$ \\
\hline Колір & \multicolumn{4}{|c|}{ Білий з кремовим відтінком, рівномірний за всією масою } \\
\hline
\end{tabular}

Органолептичні дослідження модельних зразків (табл. 1) свідчать про те, що вміст концентрату сироваткових білків у кількості 0,8\% надає сметані в'яжучого післясмаку. Натомість масова частка концентратів сироваткових білків 0,4\% $є$ недостатньою, призводить до недостатньо щільного згустку та виділення вологи зі сметани. Тому для промислового впровадження рекомедовано рецептуру сметани 3 масовою часткою жиру 10\%, до складу якої входить 0,6 \% концентрату сироваткових білків.

Зміцнення структури кисловершкового згустку дасть змогу виготовляти сметану з масовою часткою жиру $10 \%$ резервуарним способом без зниження іiі органолептичних показників якості.

Перспектива подальших досліджень полягає у вивченні структурно-механічних характеристик сметани 3 молочно-білковим концентратом та розрахунку біологічної цінності нового виду продукту.

Висновки. Доведено технологічну доцільність застосування концентрату сироваткових білків у складі сметани з масовою часткою жиру $10 \%$.

За комплексом органолептичних і фізико-хімічних показників якості встановлено раціональний вміст концентрату сироваткових білків у складі сметани у кількості $0,6 \%$.

Сметану 3 концентратом сироваткових білків у кількості 0,6 \% можна виготовляти резервуварним способом, перекачувати по трубопроводам без ризику руйнування структури та фасувати у всі види споживчої тари.

\section{ЛІТЕРАТУРА}

1. Гнічевич В.A. Реологічні властивості молочно-білкових концентратів / В.А. Гніцевич, Л.Г. Дейниченко, А.Б. Горальчук // Наукові праці Національного університету харчових технологій. — Київ : НУХТ, 2017. — Том 23, № 2. - С. 182-190.

2. Грек $O$. Вплив концентрату білка - регулятора в'язкісних характеристик на консистенцію кисломолочного напою / О. Грек, О. Красуля, Т. Пшенична // Продовольча індустрія АПК. - 2016. - № 4. - С. 27-31.

3. Дідух Г.В. Отримання мікропартикуляту з концентрату білків молочної сироватки / Г.В. Дідух // Хімія харчових продуктів і матеріалів. Нові види сировини. - 2015. C. $52-56$.

4. Просеков А.Ю. Молочно-белковые концентраты с пенообразной структурой / А.Ю. Просеков, С.А. Иванова, В. С. Сметанин // Молочная промышленность. - 2011 . № 5. - C. $64-65$. 
5. Мінорова А.В. Дослідження мікроструктури та поверхнево-активних властивостей сухих концентратів сироваткових білків, отриманих метедом ультрафільтрації / А.В. Мінорова, І.О. Романчук, Н.Л. Крушельницька, Л.М. Мацько // Збірник наукових праць Вінницького національного аграрного університету. — 2015. - С. 89-93.

6. Мінорова А.В. Біологічна цінність сухих концентратів сироваткових білків, бібліографія / А. Мінорова // Продовольча індустрія АПК. - 2015. — № 5. - С. 25-28.

7. Luck P.J. Comparison of functional properties of $34 \%$ and $80 \%$ whey protein and milk serum protein concentrates / P.J. Luc, B. Vardhanabhuti, Y.H. Yong, T. Laundon, D.M. Barbano, E.A. Foegeding. — September 2013 Volume 96, Issue 9, Pages 5522 - 5531.

8. Моісеєва Л.О. Підвищення біологічної цінності кисломолочних продуктів для харчування дітей / Л.О. Моісеєва, І.О. Романчук, Т.В. Рудакова // Збірник наукових праць Вінницького національного аграрного університету. — 2015. - С. $94-97$.

\title{
ИСПОЛЬЗОВАНИЕ КОНЦЕНТРАТА СЫВОРОТОЧНЫХ БЕЛКОВ ДЛЯ СТАБИЛИЗАЦИИ СТРУКТУРЫ СМЕТАНЫ
}

\author{
М.Р. Однорог, Г.Е. Полищук \\ Национальный университет пищевых технологий
}

В статье приведены результаты исследования фрункционально-технологических свойств молочно-белкового концентрата в составе сметаны. Основные результаты работы заключаются в обосновании рационального содержания КСБ-УФ в составе сметаны с низким содержанием жира $(0,6 \%)$ на основе анализа комплекса органолептических и фризико-химических показателей готового продукта, а также в объяснении механизма структурирования кислосливочного сгустка в присутствии сывороточных белков. Доказано, что белковый конценmрат за счет эфрфективного связывания воды влияет на активность молочнокислой микрофрлоры пропорционально его содержания, что позволяет регулировать кислотность низкожирной сметанной основы. КСБ-УФ способствует образованию нежного и насыщенного мелкодиспергованой влагой сгусток, который характеризуется отсутствием синерезиса. Установлено, что для достижения кислотности сквашенных сливок с концентратом сывороточных белков не ниже $60^{\circ} \mathrm{T}$ продолжительность сквашивания следует удлинять до 1,5 ч по сравнению с сквашиванием сливок без концентрата.

Ключевые слова: молочно-белковые концентраты, сывороточные белки, сметана. 


\title{
УДК 664.045-5
}

\section{ESTIMATION OF CELLULAR JUICE LOSSES AND SHIFTS OF ORGANOLEPTIC INDICES IN FROZEN FRUIT DURING THEIR PROLONGED STORAGE AND DEFROSTATION}

\author{
G. Simakhina, S. Kamins'ka, T. Martynenko \\ National University of Food Technologies
}

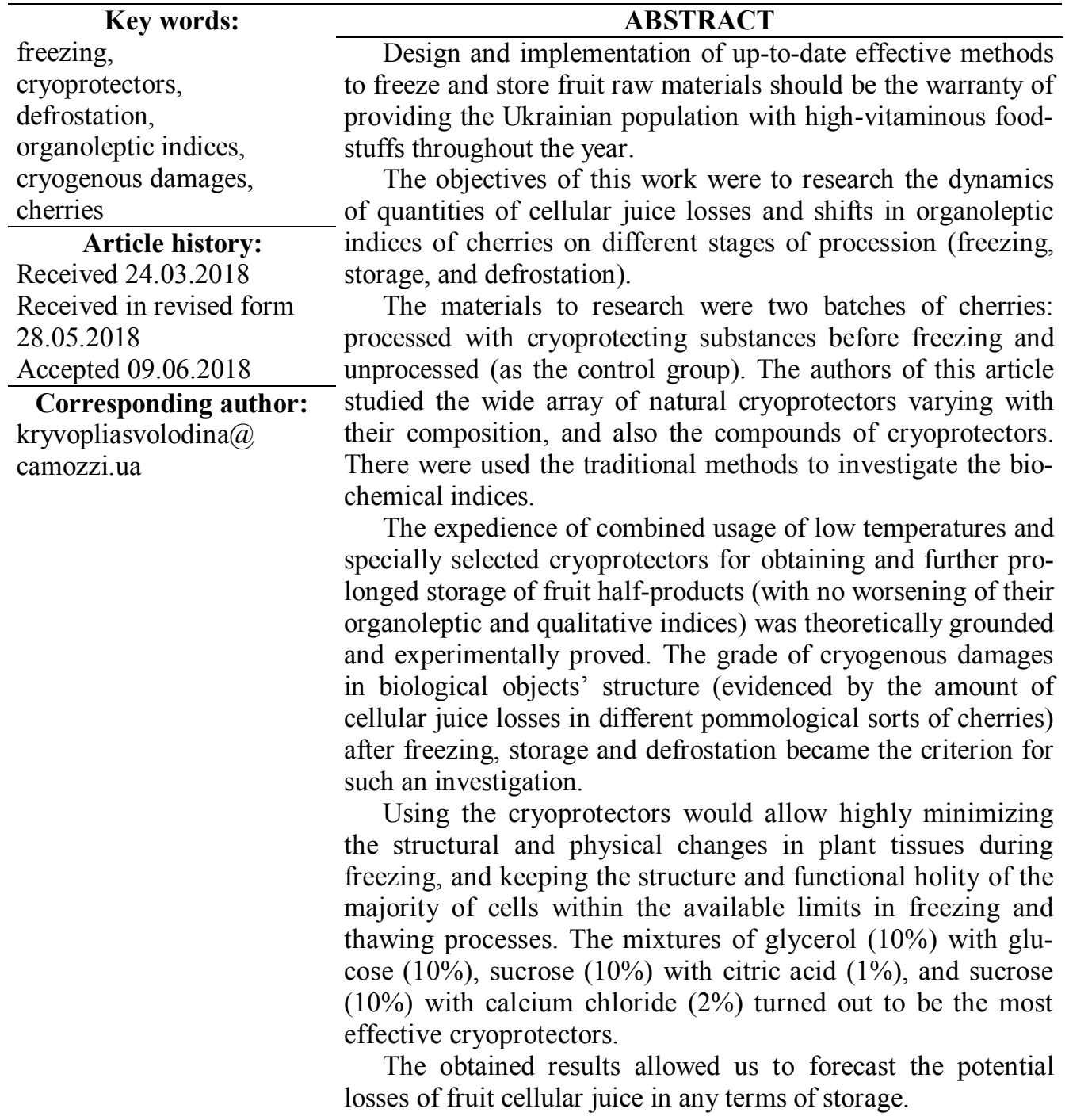

DOI: $10.24263 / 2225-2916-2018-23-4$ 


\title{
ОЦІНКА ВТРАТ КЛІТИННОГО СОКУ \\ ТА ЗМІНИ ОРГАНОЛЕПТИЧНИХ ПОКАЗНИКІВ \\ ЗАМОРОЖЕНИХ ПЛОДІВ \\ ПРИ ТРИВАЛОМУ ЗБЕРІГАННІ І ДЕФРОСТАЦІЇ
}

\author{
Г.О. Сімахіна, д-р техн. наук \\ С.В. Камінська, аспірант \\ Т.А. Мартиненко, асистент \\ Національний університет харчових технологій
}

Теоретично обгрунтовано, експериментально підтверджено доцільність поєднаного використання низьких температур і спеціально підібраних кріопротекторів при отриманні й тривалому зберіганні плодових напівфабрикатів без погіршення їхніх органолептичних та якісних показників. Критерій такої оцінки - ступінь кріоушкоджень структури біооб'єктів, непрямим свідченням якого є величина втрат клітинного соку плодів вишні різних помологічних сортів після заморожування, зберігання, дефрростації.

Ключові слова: заморожування, кріопротектори, дефростація, органолептичні властивості, кріоушкодження, плоди вишні.

Постановка проблеми. Реальний і потенційний попит на швидкозаморожену плодово-ягідну продукцію визначається сукупністю чинників, серед яких пріоритетного значення набирає іï біологічна цінність (що характеризується вмістом вітамінів, мінорних сполук, мінеральних елементів тощо), ефективність, безпека, відповідність принципам здорового харчування, органолептичні показники, на які передусім звертають увагу споживачі. Такі запити мотивують виробників до впровадження сучасних способів заморожування та зберігання рослинної сировини $[1 ; 2]$.

Результати виконаних досліджень та літературні дані свідчать про те, що подовжити термін зберігання плодово-ягідної продукції без погіршення якісних та органолептичних показників на рівні вихідної сировини найбільш реально 3 використанням низькотемпературних технологій i консервування та попереднього оброблення кріопротекторами [3].

Особливої уваги потребують ті біооб'єкти, які в свіжому вигляді мають невеликий термін зберігання. Наприклад, ягоди вишні при температурі $-1 \ldots 0^{\circ} \mathrm{C}$ та відносній вологості повітря 95\% втрачають свої якісні та кількісні показники уже через 15 діб [4], а в модифікованому газовому середовищі за тих же умов - 2 місяці [5]. Однак i цього недостатньо для забезпечення населення України високовітамінною продукцією впродовж року, тому необхідно продовжувати дослідження в цьому напрямі, вдосконалюючи сучасні технології заморожування сировини [6].

Оцінюючи ефективність результатів різних способів заморожування, ми зазначали, що одним із найважливіших показників є створення умов, за яких плоди та ягоди майже не деформуються і їхня структура не руйнується при дефростації, що забезпечує мінімальні втрати соку, практично повне збереження вмісту БАР на рівні вихідної сировини, високі органолептичні показники розморожених напівфабрикатів.

Мета статті: дослідження динаміки величин втрат клітинного соку та зміни органолептичних показників ягід вишні після заморожування, зберігання та дефростації. 
Матеріали і методи. Ягоди вишні перед заморожуванням обробляли розчинами кріопротекторів, ефективність яких було попередньо встановлено. Контролем служили зразки, необроблені кріопротекторами. Підготовка ягід вишні передбачала сортування, інспекцію, миття, видалення залишку вологи, витримування в розчині кріопротекторів протягом $30 . .60$ хв за кімнатної температури.

Літературні дані з використання кріопротекторів при заморожуванні свідчать про те, що для низькотемпературного консервування різних біологічних об’єктів використовують різноманітні за своєю природою і складом композиції, що містять власне кріопротектори (гліцерин, диметилсульфоксид тощо) та інші сполуки, біокатіони, метаболіти та інгібітори метаболізму, що дають можливість покращувати стан фізіологічних і метаболічних систем клітин, які піддаються заморожуванню й відігріванню [7].

Також індивідуальними є способи попереднього оброблення матеріалів розчинами кріопротекторів, створення їх композицій та час оброблення сировини. На підставі виконаних попередніх досліджень було підібрано оптимальні концентрації кріопротекторів та їх композиції для досліджуваних видів ягід.

Результати досліджень. Відомо, що не всі види і не всі помологічні сорти плодів і ягід придатні до заморожування й тривалого зберігання. Аналіз літературних даних, результати власних досліджень показали, що 3 сортів вишні придатні до заморожування плоди 3 достатньою кислотністю та цукристістю, красивим темним або рожевим забарвленням. Цим вимогам відповідають такі сорти вишні: Володимирська, Шубинка, Мічуріна плодюча, Шпанка, Мономах. Тому вони й обрані як предмети досліджень.

Після оброблення кріопротекторами досліджувані зразки заморожували в камері розсипом при достатніх швидкостях руху холодоносія $(2 \ldots 5$ об/хв) i температурі $-30 \ldots-35^{\circ} \mathrm{C}$. Таке зниження температури відповідає параметрам шокового заморожування, яке, як уже зазначали, є одним із сучасних популярних методів консервування рослинної сировини [8]. Він практично не викликає змін структури та хімічного складу біооб'єктів, оскільки при цьому спостерігається ефект мікрокристалізації вологи, що міститься в них. Заморожування проводили до досягнення в центрі плодів температури $-18 \pm 1^{\circ} \mathrm{C}$, і при цій же температурі їх зберігали протягом 6 місяців.

Дефростацію проводили при температурі $37 . .40^{\circ} \mathrm{C}$ на водяній бані. Технологія заморожування, зберігання, дефростації відповідала вимогам чинних інструкцій. Оцінювали втрати клітинного соку плодів вишні свіжої, після заморожування і протягом 1, 3, 6 місяців зберігання. Результати наведено в табл. 1.

Таблиия 1. Залежність втрат клітинного соку плодів вишні сорту Володимирська при заморожуванні і дефростації від виду кріопротектора, \%

\begin{tabular}{|c|c|c|c|c|}
\hline \multirow{2}{*}{ Вид кріопротектора } & \multicolumn{4}{|c|}{ Втрати клітинного соку, \% } \\
\cline { 2 - 5 } & \multirow{2}{*}{ Заморожених } & \multicolumn{3}{|c|}{ Після зберігання, міс. } \\
\cline { 3 - 5 } & & 1 & 3 & 6 \\
\hline Контроль & 28,8 & 27,8 & 28,6 & 36,0 \\
\hline Гліцерин, $10 \%$ & 18,4 & 19,6 & 21,2 & 18,4 \\
\hline Гліцерин, $10 \%+$ глюкоза, $10 \%$ & 11,8 & 12,2 & 13,4 & 12,8 \\
\hline Глюкоза, $10 \%$ & 19,6 & 20,8 & 22,5 & 18,2 \\
\hline Сахароза, $10 \%$ & 22,4 & 24,0 & 24,8 & 23,6 \\
\hline Сахароза, $10 \%+\mathrm{CaC1}_{2}, 2 \%$ & 16,2 & 17,8 & 19,4 & 19,8 \\
\hline Сахароза, $10 \%+$ лимонна к-та, $1 \%$ & 13,0 & 13,4 & 14,2 & 13,5 \\
\hline
\end{tabular}


Аналіз даних табл. 1 дає змогу зробити ряд висновків:

- максимальна величина втрат клітинного соку спостерігається відразу після заморожування сировини і складає 23,1\% (контроль) і від 7,1 до 17,7 \% при використанні кріопротекторів;

- у процесі зберіганні навіть протягом шести місяців втрати клітинного соку після дефростації ягід, заморожених 3 використанням кріопротекторів, практично не збільшились;

- втрати клітинного соку при дефростації є результатом кріоушкоджуючих виявів у клітині, які визначаються фазовим переходом води в лід та наявністю кріопротекторів.

Біологічні системи піддаються найбільш сильному впливові комплексу цих ушкоджуючих чинників (внутрішньоклітинна кристалізація, рекристалізація, гіперконцентрація солей тощо), яким не вдається повністю запобігти навіть із використання композицій ефективних кріопротекторів, саме на етапі виморожування води. Тому щойно заморожені ягоди при дефростації втрачають найбільше клітинного соку, а подальше зберігання при низьких температурах майже не поглиблює цей процес;

- разом $з$ тим використання кріопротекторів дає можливість значно нівелювати структурно-фізичні зміни рослинних тканин при заморожуванні і в реально доступних межах зберігати структуру i функціональну цілісність більшості клітин у процесах заморожування-відігрівання;

- аналіз втрат клітинного соку при дефростації швидкозаморожених ягід через шість місяців їх зберігання дає можливість припустити, що температура зберігання нижче нуля $\left(-18^{\circ} \mathrm{C}\right)$ також відіграє роль захисного чинника, який підтримує цілісність тих клітин, які залишились незруйнованими після заморожування;

- із досліджених кріопротекторів найбільш ефективними виявились суміші гліцерин (10\%) спільно з глюкозою (10\%); сахароза (10\%) спільно з лимонною кислотою (1\%); сахароза (10\%) спільно з $\mathrm{CaCl}_{2}(2 \%)$.

Отримані дані добре узгоджуються $з$ результатами досліджень авторів [9; 10], виконаних в Одеській національній академії харчових технологій.

Вишні, оброблені кріопротекторами перед заморожуванням і через шість місяців зберігання, після дефростації втрачають, порівняно зі свіжою сировиною, лише на $8,1 \ldots 18,9 \%$ більше клітинного соку; водночас ягоди, не оброблені кріопротекторами, втрачають при дефростації 31,3\% соку.

Вишні, заморожені з використанням кріопротекторів, протягом усіх шести місяців зберігання мають приємний смак, аромат, природне забарвлення i свіжий вигляд; заморожені без кріопротекторів ягоди менш стійкі; при тривалому зберіганні, а також при нерівномірній температурі повітря в камерах вони під впливом оксидазних ферментів і кисню повітря починають швидко змінювати забарвлення, набирають бурого кольору, втрачаюсь смак і аромат.

Про це свідчать результати дегустаційної оцінки заморожених плодів вишні після шести місяців зберігання (табл. 2).

3 даних, наведених у табл. 2, видно, що плоди вишні всіх досліджених сортів, оброблені перед заморожуванням кріопротекторами оцінюються досить високо, причому зниження бальної оцінки плодів після заморожування і тривалого зберігання не перевищує 0,5 бала за зовнішнім виглядом; 0,3 бала - за консистенцією; 0,4 бала — за ароматом; 0,1 бала — за показником смаку (за винятком 
вишні сорту Мономах). А показник кольору залишився майже на рівні вихідної сировини. Це особливо характерно для плодів сорту Мічуріна плодюча та Володимирська, які отримали найвищі дегустаційні бали за всіма показниками, зокрема, зміна кольору після заморожування не змінилась (5,0 балів).

Таблиця 2. Дегустаційна оцінка плодів вишні при заморожуванні 3 кріопротекторами і зберіганні протягом шести місяців

\begin{tabular}{|c|c|c|c|c|c|c|c|}
\hline \multirow[b]{2}{*}{ Сорт вишні } & \multirow[b]{2}{*}{ Вид продукції } & \multicolumn{6}{|c|}{ Оцінка за 5-бальною системою } \\
\hline & & $\begin{array}{c}\text { Зовнішній } \\
\text { вигляд }\end{array}$ & $\begin{array}{c}\text { Консис- } \\
\text { тенція }\end{array}$ & Аромат & Колір & $\begin{array}{c}\text { Показник } \\
\text { смаку }\end{array}$ & $\begin{array}{c}\text { Загальна } \\
\text { оцінка }\end{array}$ \\
\hline \multirow{3}{*}{ Мономах } & до заморожування & 4,4 & 4,3 & 4,2 & 4,8 & 4,4 & 4,42 \\
\hline & після заморожування & 4,5 & 4,4 & 4,5 & 4,8 & 4,4 & 4,52 \\
\hline & через 6 місяців & 4,2 & 4,0 & 3,8 & 4,6 & 3,4 & 4 \\
\hline \multirow{3}{*}{ Шубина } & до заморожування & 4,5 & 4,4 & 4,6 & 4,45 & 4,4 & 4,47 \\
\hline & після заморожування & 4,5 & 4,2 & 4,7 & 4,3 & 4,3 & 4,4 \\
\hline & через 6 місяців & 4,0 & 4,2 & 4,2 & 4,2 & 4,3 & 4,18 \\
\hline \multirow{3}{*}{ Шпанка } & до заморожування & 4,6 & 4,7 & 4,7 & 4,7 & 4,5 & 4,64 \\
\hline & після заморожування & 4,4 & 4,3 & 4,5 & 4,7 & 4,4 & 4,46 \\
\hline & через 6 місяців & 4,5 & 4,6 & 4,5 & 4,4 & 4,4 & 4,48 \\
\hline \multirow{3}{*}{$\begin{array}{l}\text { Мічуріна } \\
\text { плодюча }\end{array}$} & до заморожування & 5 & 4,7 & 4,8 & 5 & 4,6 & 4,82 \\
\hline & після заморожування & 5 & 4,8 & 4,8 & 5 & 4,5 & 4,82 \\
\hline & через 6 місяців & 5 & 4,6 & 4,7 & 4,9 & 4,6 & 4,76 \\
\hline \multirow{3}{*}{$\begin{array}{l}\text { Володи- } \\
\text { мирська }\end{array}$} & до заморожування & 5 & 4,8 & 4,8 & 5 & 4,6 & 4,84 \\
\hline & після заморожування & 5 & 4,7 & 4,6 & 5 & 4,7 & 4,8 \\
\hline & через 6 місяців & 5 & 4,7 & 4,6 & 4,9 & 4,8 & 4,8 \\
\hline \multirow{3}{*}{$\begin{array}{c}\text { Володи- } \\
\text { мирська (без } \\
\text { кріопро- } \\
\text { тектора) }\end{array}$} & до заморожування & 5 & 4,8 & 4,8 & 5 & 4,6 & 4,84 \\
\hline & після заморожування & 4,2 & 4,0 & 4,6 & 4,1 & 4,6 & 4,3 \\
\hline & через 6 місяців & 3,6 & 3,3 & 3,8 & 2,6 & 4,0 & 3,46 \\
\hline
\end{tabular}

На відміну від цих результатів, оцінка плодів, заморожених без кріопротекторів, різко знижується відразу після дії низьких температур, а особливо після тривалого зберігання. Так, сорт вишні Володимирська, який відзначається чудовими вихідними даними, після дефростації оцінено за зовнішній вигляд всього в 3,6 бала, а за показником кольору - 2,6 бала.

Пояснення цьому можна знайти, виходячи з теорії кріоушкоджень біооб'єктів, сформульованих відомими вченими Е. Алмаші, Я. Подольськи, 3. Груби, М. Головкіним, Г. Чижовим та іншими. На особливу уваги заслуговують праці О. Білоуса, Е. Гордієнко, Л. Розанової, М. Пушкаря, присвячені питанням заморожування та кріопротекції в медицині. 3 цих досліджень випливає, що для всіх біологічних об'єктів, до яких відноситься і плодово-ягідна сировина, існує одна закономірність - при охолодженні до $0^{\circ} \mathrm{C}$ і під впливом негативних температур клітини можуть руйнуватись. У цьому явищі варто розрізняти як ушкодження, пов'язані 3 комплексом процесів у мембрані і клітині при розвитку температурного шоку, так і руйнування клітин, пов'язані з дією негативних температур. В останньому випадку це відбувається, коли кристалізується поза- або внутрішньоклітинний розчин і клітини руйнуються утвореними кристалами [11].

Для нас важливим є саме цей випадок, оскільки в зруйнованих клітинах інтенсивно діють пероксидази (що підтверджено попередніми дослідженнями). 
Найголовніше полягає в тому, що заморожені продукти перед вживанням або подальшим переробленням піддаються розморожуванню (дефростації). I якщо вони міститимуть багато зруйнованих клітин, то при дефростації втрачається клітинний сік, якість продукту погіршується, його біологічна цінність різко падає. I навіть із найбільш якісної сировини неможливо отримати ідентичні продукти, що і підтверджується результатами таблиць 1 і 2.

Зважаючи на високий вміст у досліджуваній сировині біофлавоноїдів та аскорбінової кислоти, у технології заморожування слід передбачити інактивацію ферментів, насамперед поліфенолоксидази, що містять як кофермент іони міді і викликають окислення фенольних сполук 3 однією чи кількома фенольними групами молекулярним киснем.

У результаті окислені тканини набирають темно-коричневого забарвлення, неприємного смаку і запаху. Ці реакції спостерігаються не лише у фруктах та ягодах, а й в овочевих культурах.

Для того, щоб установити закономірності ступеня кріоушкоджень структури біооб'єктів і пов'язаних із цим втрат клітинного соку після дефростації, аналогічні дослідження провели із плодами вишні різних сортів (табл. 3-6).

Таблиия 3. Залежність втрат клітинного соку плодів вишні сорту Шубинка при заморожуванні і дефростації від виду кріопротектора, \%

\begin{tabular}{|c|c|c|c|c|}
\hline \multirow{2}{*}{ Вид кріопротектора } & \multicolumn{4}{|c|}{ Втрати клітинного соку, \% } \\
\cline { 2 - 4 } & \multirow{2}{*}{ Заморожених } & \multicolumn{3}{|c|}{ Після зберігання, міс } \\
\cline { 3 - 5 } & & 1 & 3 & 6 \\
\hline Контроль & 34,2 & 35,8 & 36,2 & 35,6 \\
\hline Гліцерин, $10 \%$ & 28,8 & 27,9 & 26,2 & 28,0 \\
\hline Гліцерин, $10 \%+$ глюкоза, $10 \%$ & 22,0 & 24,6 & 23,4 & 23,8 \\
\hline Глюкоза, $10 \%$ & 24,6 & 26,0 & 24,5 & 25,6 \\
\hline Сахароза, $10 \%$ & 26,8 & 24,8 & 26,0 & 27,2 \\
\hline Сахароза, $10 \%+\mathrm{CaC1}_{2}, 2 \%$ & 23,2 & 25,4 & 24,2 & 24,8 \\
\hline Сахароза, $10 \%+$ лимонна к-та, $1 \%$ & 22,4 & 25,8 & 23,0 & 24,0 \\
\hline
\end{tabular}

Таблиия 4. Залежність втрат клітинного соку плодів вишні сорту Мічуріна плодюча при заморожуванні і дефростації від виду кріопротектора, \%

\begin{tabular}{|c|c|c|c|c|}
\hline \multirow{2}{*}{ Вид кріопротектора } & \multicolumn{4}{|c|}{ Втрати клітинного соку, \% } \\
\cline { 2 - 5 } & \multirow{2}{*}{ Заморожених } & \multicolumn{3}{|c|}{ Після зберігання, міс } \\
\cline { 3 - 5 } & & 1 & 3 & 6 \\
\hline Контроль & 28,4 & 31,4 & 32,8 & 30,0 \\
\hline Гліцерин, $10 \%$ & 22,5 & 24,6 & 25,4 & 24,2 \\
\hline Гліцерин, 10\%+ глюкоза, $10 \%$ & 18,2 & 17,8 & 19,0 & 18,6 \\
\hline Глюкоза, $10 \%$ & 21,8 & 22,4 & 23,0 & 22,0 \\
\hline Сахароза, $10 \%$ & 24,4 & 24,4 & 24,2 & 25,6 \\
\hline Сахароза, $10 \%+\mathrm{CaC}_{2}, 2 \%$ & 21,6 & 19,6 & 20,6 & 22,4 \\
\hline Сахароза, $10 \%+$ лимонна к-та, $1 \%$ & 18,8 & 18,4 & 19,2 & 19,8 \\
\hline
\end{tabular}

Таблиця 5. Залежність втрат клітинного соку плодів вишні сорту Мономах при заморожуванні і дефростації від виду кріопротектора, \%

\begin{tabular}{|c|c|c|c|c|}
\hline \multirow{2}{*}{ Вид кріопротектора } & \multicolumn{4}{|c|}{ Втрати клітинного соку, \% } \\
\cline { 2 - 5 } & \multirow{2}{*}{ Заморожених } & \multicolumn{3}{|c|}{ Після зберігання, міс } \\
\cline { 3 - 5 } & & 1 & 3 & 6 \\
\hline 1 & 2 & 3 & 4 & 5 \\
\hline Контроль & 35,6 & 36,6 & 35,2 & 36,2 \\
\hline
\end{tabular}




\begin{tabular}{|c|c|c|c|c|}
\hline \multicolumn{5}{c|}{ Продовження табл. 5 } \\
\hline 1 & 2 & 3 & 4 & 5 \\
\hline Гліцерин, $10 \%$ & 30,0 & 32,0 & 33,2 & 31,4 \\
\hline Гліцерин, $10 \%+$ глюкоза, $10 \%$ & 24,8 & 25,4 & 25,0 & 24,2 \\
\hline Глюкоза, $10 \%$ & 26,6 & 27,8 & 29,0 & 27,0 \\
\hline Сахароза, $10 \%$ & 27,0 & 27,0 & 28,4 & 28,8 \\
\hline Сахароза, $10 \%+\mathrm{CaC1}_{2}, 2 \%$ & 25,4 & 24,4 & 24,8 & 26,2 \\
\hline Сахароза, $10 \%+$ лимонна к-та, $1 \%$ & 25,2 & 22,8 & 20,6 & 24,8 \\
\hline
\end{tabular}

Таблиия 6. Залежність втрат клітинного соку плодів вишні сорту Шпанка при заморожуванні і дефростації від виду кріопротектора, \%

\begin{tabular}{|c|c|c|c|c|}
\hline \multirow{2}{*}{ Вид кріопротектора } & \multicolumn{4}{|c|}{ Втрати клітинного соку, \% } \\
\cline { 2 - 5 } & \multirow{2}{*}{ Заморожених } & \multicolumn{3}{|c|}{ Після зберіганн, міс } \\
\cline { 3 - 5 } & & 1 & 3 & 6 \\
\hline Контроль & 41,4 & 42,8 & 40,6 & 44,4 \\
\hline Гліцерин, $10 \%$ & 36,2 & 35,6 & 37,0 & 38,2 \\
\hline Гліцерин, $10 \%+$ глюкоза, 10\% & 36,0 & 34,8 & 36,6 & 37,8 \\
\hline Глюкоза, $10 \%$ & 32,8 & 34,0 & 32,0 & 34,2 \\
\hline Сахароза, $10 \%$ & 32,8 & 34,6 & 33,4 & 34,8 \\
\hline Сахароза, $10 \%+\mathrm{CaC1}_{2}, 2 \%$ & 30,6 & 32,4 & 33,6 & 31,4 \\
\hline Сахароза, $10 \%+$ лимонна к-та, $1 \%$ & 31,4 & 32,8 & 33,0 & 30,6 \\
\hline
\end{tabular}

Порівняльний аналіз даних табл. 1-6 показує, шо погіршення якості вишні, викликане заморожуванням і тривалим зберіганням, залежить від їх сорту. Причому це погіршення виявлялось незалежно від виду кріопротектора i швидкості заморожування. Такі результати є особливо характерними для сорту вишень Шпанка: якщо при дефростування плодів вишні сорту Володимирська втрати клітинного соку у контрольному зразку становлять $31,3 \%$, то для плодів сорту Шпанка цей показник зріс до $38,4 \%$, а у зразках, оброблених композицією кріопротекторів - сахарози і лимонної кислоти, ці показники складають, відповідно, $8,8 \%$ та 24,6\%.

Висновки. Сортові особливості сировини значною мірою визначають ступінь кріоушкодження структури тканин і клітин при заморожуванні, і це ще раз підкреслює необхідність індивідуального підбору кріопротекторів для кожного виду продукції, що підлягає заморожуванню.

За ступенем кріоушкоджень структури і величиною втрат клітинного соку досліджені сорти плодів вишні складають такий ряд (за зростанням зазначених показників):

\section{Володимирська $<$ Мічуріна плодюча $<$ Шубнка $<$ Мономах $<$ Шпанка.}

Це пояснюється, очевидно, різним якісним складом клітинних оболонок плодів вишні різних сортів, передусім вмістом пектинових речовин, геміцелюлоз тощо, які можуть впливати на ступінь проникності кріопротекторів всередину клітин і викликаних ними позитивних змін. Тобто найбільш придатними до заморожування, тривалого зберігання й отримання високоякісних напівфабрикатів є перші три сорти плодів вишні.

Отримані порівняльні дані величини втрат соку після заморожування та в процесі зберігання для кожного дослідженого сорту вишень дають можливість прогнозувати потенційні втрати клітинного соку при будь-яких термінах збері- 
гання за значенням цього показника у дефростованих плодах відразу після розморожування.

\title{
ЛІТЕРАТУРА
}

1. Белінська С.О. Наукові і практичні засади розроблення рецептур і формування якості швидкозаморожених плодоовочевих продуктів / С.О. Белінська // Харч. і перероб. промисловість. - 2009. - №11-12. - С. 26-28.

2. Хариевич Ю.Т. Хранение плодов и овощей / Ю.Т. Харцевич. - М. : Харвест, 2003. $-356 \mathrm{c}$.

3. Сімахіна Г.О. Ефективність використання кріопротекторів при заморожуванні дикорослих і культивованих ягід / Г.О. Сімахіна, С.В. Халапсіна // Наукові праці Національного університету харчових технологій. — 2017. — Т. 23, № 3. — С. 179-185. $264 \mathrm{c}$.

4. Барабаш А. Косточковые культуры / А. Барабаш. - М. : Агропромиздат, 1987. —

5. Найченко В.M. О возможности хранения свежих плодов вишни / В.М. Найченко, Н.М. Осокина // Холодильная техника. - 1984. - № 9. - С. 31-33.

6. Орлова Н.Я. Заморожені плодоовочеві продукти: проблеми формування асортименту та якості : монографія / Н.Я. Орлова, С.О. Белінська. — К. : Київ. нац. торг.-екон. ун-т, 2005. - $335 \mathrm{c}$.

7. Белоус А.М. Биохимия мембран. Книга 3. Замораживание и криопротекция / А.М. Белоус, Е.А. Гордиенко, Л.Ф. Розанов. - М. : Высшая школа, 1987. - 80 с.

8. Павлюк Р.Ю. Нове в технології отримання заморожених ягід та пюре з рекордними характеристиками / Р.Ю. Павлюк, В.В. Погарська та ін. // Прогресивні техніка та технології харчових виробництв ресторанного господарства і торгівлі. - 2013. Вип. 1(1). - С. 3-9.

9. Доценко Н.В. Проблеми захисту рослинної сировини за допомогою кріопротекції / Н.В. Доценко // Зб. наук. праць ОДАХТ. - 1998. - Вип. 18. - С. 38-41.

10. Доценко Н.В. Кріозахист айви при заморожуванні / Н.В. Доценко, Є.Г. Кротов, А.А. Бровченко // Харч. і перероб. промисловість. - 1997. — № 12. — С. $24-25$.

11. Пушкарь Н.С. Низкотемпературная кристаллизация в биологических системах / Н.С. Пушкарь, А.М. Белоус, Ю.А. Иткин и др. - К. : Наук. думка, 1997. - 238 с.

\section{ОЦЕНКА ПОТЕРЬ КЛЕТОЧНОГО СОКА И ИЗМЕНЕНИЯ ОРГАНОЛЕПТИЧЕСКИХ ПОКАЗАТЕЛЕЙ ЗАМОРОЖЕННЫХ ПЛОДОВ ПРИ ДЛИТЕЛЬНОМ ХРАНЕНИИ И ДЕФРОСТАЦИИ}

\author{
Г.А. Симахина, С.В. Каминская, Т.А. Мартыненко \\ Национальний университет пищевых технологій
}

Теоретически обоснована, экспериментально подтверждена целесообразность комбинированного использования низких температур и специально подобранных криопротекторов при получении и длительном хранении плодовых полуфабрикатов без ухудшения их органолептических и качественных показателей. Критерий такой оценки - степень криоповреждений структуры биообъектов, косвенным свидетельством которого является величина потерь клеточного сока плодов вишни разных помологических сортов после замораживания, хранения, дефростации.

Ключевые слова: замораживание, криопротекторы, дефростация, органолептические свойства, криоповреждения, плоды вишни. 


\title{
удк 664.64.016.8
}

\section{INFLUENCE OF VEGETABLE PROTEIN ISOLATES ON GLUTEN COMPLEX OF WHEAT DOUGH}

\author{
V. Makhynko, A. Sharan, L. Sharan, L. Chernish \\ National University of Food Technologies
}

\begin{tabular}{|c|c|}
\hline & ABSTRACT \\
\hline $\begin{array}{l}\text { protein, } \\
\text { gluten, } \\
\text { soybeans, } \\
\text { peas, } \\
\text { rice, } \\
\text { dough, } \\
\text { factions }\end{array}$ & $\begin{array}{l}\text { Chemical composition of traditional bakeries good are high un- } \\
\text { balanced: content of over quantity of carbohydrates and not enough } \\
\text { amount of protein. As the main part of carbohydrates is added by } \\
\text { flour and can't be significantly reduced, above indicated problem } \\
\text { could be solved by adding an additional portion of protein to the } \\
\text { goods made of wheat flour. More desirable should be plant raw } \\
\text { material. Also should be taken into account that wheat protein con- }\end{array}$ \\
\hline $\begin{array}{l}\quad \text { Article history: } \\
\text { Received 20.03.2018 } \\
\text { Received in revised form } \\
\text { 10.04.2018 } \\
\text { Accepted } 31.05 .2018 \\
\end{array}$ & $\begin{array}{l}\text { tains not enough quantity of lysine, therefore best protein fortifiers } \\
\text { based on parameter of amino acids complementarity are products } \\
\text { of beans processing which contains certain amount of lysine } \\
\text { overbalance (soy beans, peas, nut). The isolates should be more } \\
\text { preferable as during its production process main amount of beans }\end{array}$ \\
\hline $\begin{array}{l}\text { Corresponding author: } \\
\text { mavam78@gmail.com }\end{array}$ & $\begin{array}{l}\text { antinutrients were inactivated. High content of protein in isolates } \\
\text { (appr. 90\%) gives the opportunity to use it in small amounts that } \\
\text { significantly increase food and biological value of goods. To avoid } \\
\text { deterioration of consumer's properties of the fortified goods, we } \\
\text { proposed to use together with isolates also dry wheat gluten (as } \\
\text { protein and technological additive). The purpose of this work was } \\
\text { to study how adding high-protein vegetable supplements (isolates } \\
\text { and dry wheat gluten) influence gluten complex of first grade flour } \\
\text { dough. Soy, pea and rice protein isolates were used. Highly water- } \\
\text { absorbing vegetable protein isolates were found to worsen gluten } \\
\text { formation. Estimated and experimental data on wet and dry gluten } \\
\text { quantity were compared. In both cases, the experimental data were } \\
\text { found to be less than the estimated data. In addition, in all samples } \\
\text { gluten's ability to hydrate decreases and its elasticity increases. To } \\
\text { explain these changes, we studied fractional composition of protein } \\
\text { substances of raw materials being examined. Protein fractions of } \\
\text { grain and bean supplements are found to be similar, however rice } \\
\text { protein isolate contains no prolamins which are present in flour. }\end{array}$ \\
\hline
\end{tabular}

\section{ВПЛИВ ІЗОЛЯТІВ РОСЛИННИХ БІЛКІВ НА КЛЕЙКОВИННИЙ КОМПЛЕКС ПШЕНИЧНОГО ТІСТА}

\author{
В.М. Махинько, канд. техн. наук \\ А.В. Шаран, канд. техн. наук \\ Л.О. Шаран, канд. техн. наук \\ Л.М. Черниш, аспірант \\ Національний університет харчових технологій \\ У статті вивчено вплив високобілкових рослинних добавок (ізолятів і сухої \\ пшеничної клейковини) на клейковинний комплекс тіста з пшеничного борошна
}

(C) В.М. Махинько, А.В. Шаран, Л.О. Шаран, Л.М. Черниш, 2018 
першого сорту. Використовували білкові ізоляти сої, гороху та рису. Встановлено, що ізоляти рослинних білків, які мають високу водопоглинальну здатність, погіршують процес утворення клейковини. Порівнювали розрахункові та експериментальні дані щодо кількості сирої та сухої клейковини. Виявили, що в обох випадках дослідні значення менші за розрахункові. Також в усіх зразках знижується гідратаційна здатність клейковини та підвищується її пружність. Для пояснення цих змін було вивчено фрракційний склад білкових речовин досліджуваної сировини. Встановлено подібність білкових фракцій добавок із зернової та бобової сировини, однак ізолят рисового білка не містить проламінів, які наявні в пшеничному борошні.

Ключові слова: білок, клейковина, соя, горох, рис, тісто, фрракції.

Постановка проблеми. Більшість видів хлібобулочних виробів характеризуються незбалансованістю хімічного складу — надлишком вуглеводів та недостатньою кількістю білків. До того ж цей білок має низьку біологічну цінність, зумовлену його амінокислотним складом: для виробів 3 пшеничного борошна скор лімітуючої амінокислоти лізину не перевищує 60 \%. Оскільки хліб займає чільне місце в раціоні харчування більшості українців, підвищення його біологічної цінності та збалансування хімічного складу є актуальним завданням фахівців харчової науки та виробництва. Вирішенню цих питань присвячено праці В.І. Дробот, Л.Ю. Арсеньєвої, В.Ф. Доценка, Л.І. Карнаушенко, Н.Т. Козьміної, Н.П. Бондар, Л.І. Пучкової, Р.Д. Поландової., С.Я. Корячкіної, Л.П. Пащенко, I.В. Матвєєвої, Т.Б. Циганової [1]. У більшості 3 цих праць зазначається, що внесення білкових добавок у кількості понад 10\% негативно впливає на перебіг технологічного процесу та якість кінцевої продукції.

Для подолання вказаних недоліків пропонуються різноманітні технологічні заходи та використання добавок-поліпшувачів. Однак більшість цих добавок має хімічну природу, а їх безпечність для організму людини остаточно не підтверджена [2]. До того ж сучасний споживач $з$ пересторогою ставиться до наявності у складі хлібобулочних виробів будь-яких хімічних речовин. Тому для підвищення біологічної цінності хліба доцільно використовувати насамперед природну сировину. Фахівцями харчової галузі проводиться активний пошук нових джерел харчового білка і вже переконливо доведено перспективність використання $з$ цією метою саме рослинної сировини [3]. Соя є однією з найпоширеніших культур, що використовується для одержання харчового білка. За обсягами вирощування сої Україна посідає перше місце у Європі, за останні роки збільшивши кількість вирощеної сої на 50\% - до 4,2 млн. т/рік. За цей же час у 3,5 раза зросла частка переробленої сої [4]. Оскільки соєвий білок можна отримувати як супутній продукт виробництва соєвої олії, використання білкових продуктів 3 сої набуває в Україні все більшого поширення. Однак при цьому слід зважати на наявність у сої певної кількості антипоживних речовин - інгібіторів травних ферментів, рафінози, стахіози тощо. Тож доцільним є використання високоочищених форм білкової сировини, наприклад, ізолятів, технологія одержання яких передбачає майже повне видалення всіх супутніх речовин. За рахунок високого ступеня очищення вміст білка в ізолятах сягає $90 \%$, що дає змогу, навіть за невеликих дозувань, суттєво впливати на харчову і біологічну цінність кінцевої продукції $[5 ; 6]$.

Зважаючи на вказані переваги ізолятів, фахівцями проводиться робота щодо ïх отримання 3 інших рослинних джерел. Насамперед розглядаються бобові культури, які містять велику кількість білка, багатого дефіцитною амінокисло- 
тою лізином [7]. Постійне удосконалення технології концентрування білкового компоненту дає змогу одержувати ізоляти рослинних білків навіть із зернових культур (наприклад, рису).

Відомо, що внесення високобілкової рослинної сировини (ВРС) може суттєво впливати на стан білкового комплексу пшеничного тіста, оскільки білок цієї сировини має інший амінокислотний склад та функціональні властивості. Зазвичай цей вплив має негативний характер, що може викликати погіршення основних фізико-хімічних показників та органолептичних характеристик готової продукції.

Метою дослідження $є$ вивчення і порівняння впливу ізолятів рослинних білків (сої, гороху та рису) та сухої пшеничної клейковини на основні характеристики клейковинного комплексу тіста з пшеничного борошна.

Матеріали і методи. У дослідженні використовували суху пшеничну клейковину виробництва «Cargill» (Польща), ізолят соєвого білка ISOPRO 900 EMUPI виробництва Shandong Sinoglory Group Co., Ltd (Китай), ізолят рисового білка виробництва Growing Naturals, LLC (США) та ізолят горохового білка виробництва Cosucra Groupe Warcoing S. А. (Бельгія). Об'єктом досліджень була нативна та висушена клейковина, характеристики якої визначали за загальноприйнятими методиками [8]. Для можливого пояснення впливу ізолятів на клейковинний комплекс тіста визначали фракційний склад білків досліджуваної сировини методом вибіркової розчинності за Осборном [9].

Результати досліджень. Утворення тіста 3 необхідними структурно-механічними властивостями можливе лише за умови наявності у борошні достатньої кількості клейковини високої якості. Внесення додаткової сировини (особливо високобілкової) буде призводити до утворення білок-білкових комплексів, що позначиться як на кількості відмитої (сирої) і висушеної клейковини, так і на іiі основних характеристиках. На першому етапі роботи аналізували зміну кількості сирої та сухої клейковини у контрольному зразку та тісті з ВРС. Оскільки попередніми дослідженнями встановлено, що вироби високої якості можна одержати лише за умови сумісного внесення ізолятів та СПК, визначення проводили для обраних співвідношень: ІСБ/СПК - 10/17, ІГБ/СПК - 10/11, ІРБ/СПК 9/12. За контроль обрали хліб пшеничний з борошна першого сорту та наявний на ринку України хліб білковий київський, до рецептури якого входить 21\% СПК. Встановлені показники водопоглинальної здатності СПК та ізолятів дають змогу порівняти розрахункові (прогнозовані) та експериментальні дані. Результати визначення кількості сирої клейковини представлено на рис. 1.

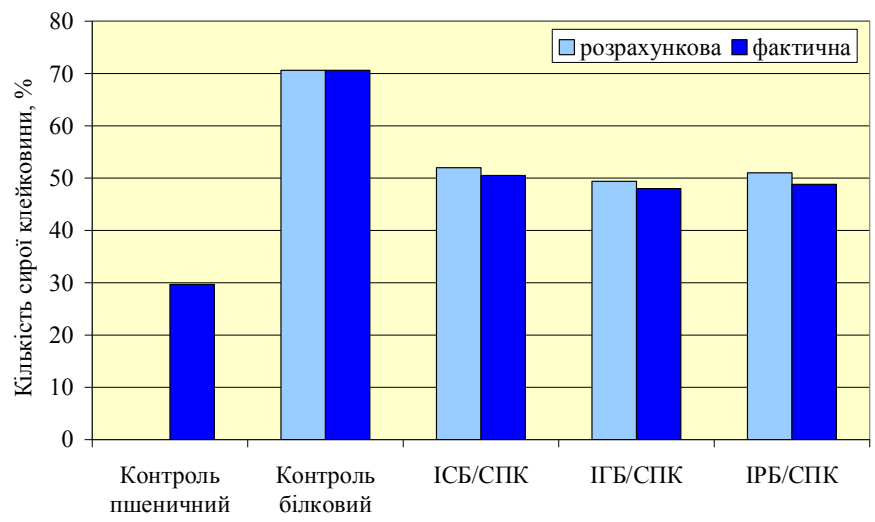

Рис. 1. Зміна кількості сирої клейковини у тісті з різною ВРС 
Як бачимо, розрахункові й експериментальні дані щодо вмісту сирої клейковини досить близькі, що дає можливість використовувати відомі коефіцієнти водопоглинальної здатності ВРС для прогнозування зміни кількості клейковини навіть за інших співвідношень рецептурних компонентів. Водночас для зразків 3 ізолятами можемо спостерігати зниження на $1,5 \ldots 2,2 \%$ фактичного вмісту сирої клейковини. Найсуттєвіші відхилення спостерігаємо у зразку з ІРБ, у той час як два інших зразки мають практично однакові величини зниження вмісту сирої клейковини. Це можна пояснити насамперед високою водопоглинальною здатністю ізолятів, що погіршує гідратацію клейковинних білків та їх агрегацію у єдиний клейковинний комплекс. Також слід зважати на можливу часткову денатурацію білків СПК, що відбулася на стадії ії промислового одержання, погіршивши здатність до об'єднання 3 нативними клейковинними білками пшеничного тіста. Для перевірки цього припущення було визначено кількість сухої клейковини (рис. 2).

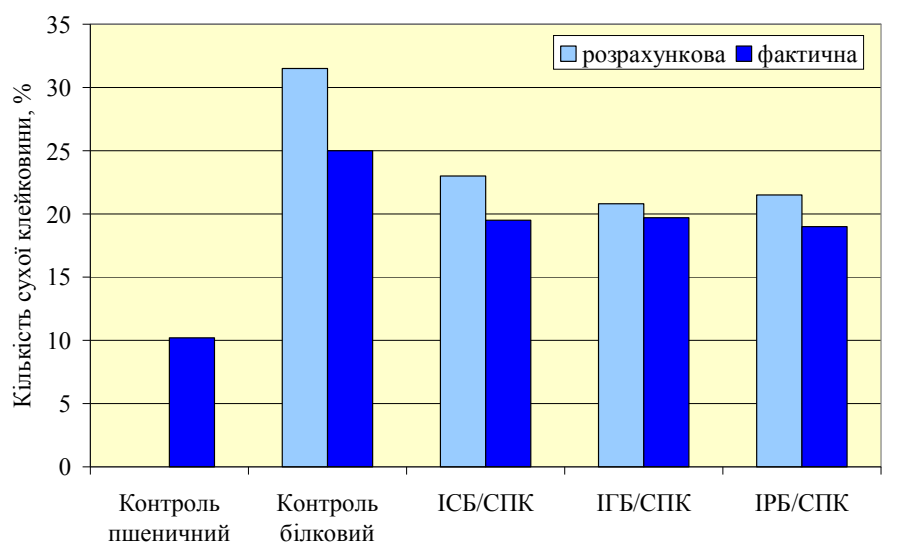

Рис. 2. Зміна кількості сухої клейковини у тісті з внесенням ВРС

Одержані дані підтверджують наше припущення щодо часткової денатурації клейковинних фракцій білків промислового виготовленої СПК. Для хліба білкового, що містить лише СПК, зниження частки фактичного вмісту сухої клейковини відносно розрахункового становить 6,5\% ( 31,5 до 25\%), для інших зразків це зменшення пропорційне загальному вмісту СПК у суміші. Найбільшим воно $€$ у зразку з ІСБ (зниження з 23 до 19,5\%).

Крім загального вмісту клейковини, важливе значення у технології хлібопечення відіграють також показники якості утвореного клейковинного комплексу. Було визначено основні характеристики одержаних зразків клейковини (табл. 1).

Аналіз одержаних даних показав, що внесення всіх видів ВРС значно погіршує гідратаційну здатність клейковини, що можна пояснити утворенням білокбілкових комплексів, в результаті чого частково блокуються гідрофільні групи та змінюється агрегатний стан макромолекул нативного клейковинного білка. Водночас спостерігається зміцнення клейковини, визначене за показником ИДК.

Таблиия 1. Зміна якості клейковини у зразках з ВРС

\begin{tabular}{|c|c|c|c|c|c|}
\hline Показники & $\begin{array}{c}\text { Контроль } \\
\text { пшеничний }\end{array}$ & $\begin{array}{c}\text { Контроль } \\
\text { білковий }\end{array}$ & ІСБ/СПК & ІГБ/СПК & ІРБ/СПК \\
\hline Гідратаційна здатність клейковини, \% & 190,7 & 153,1 & 156,4 & 168,8 & 170,3 \\
\hline Показник ИДК, од. прил. & 70 & 60,4 & 61,5 & 68,0 & 65,5 \\
\hline
\end{tabular}


Найсуттєвіші зміни відбуваються у зразку з внесенням лише СПК (показник ИДК знижується майже на 10 од. приладу), що в подальшому може суттєво вплинути на структуру м'якушки готового хліба. Інші види ВРС спричиняють дещо менший негативний вплив, однак прямої залежності між досліджуваними показниками немає. Зважаючи на відомий факт, що функціональні властивості білків зумовлені насамперед їх амінокислотним і фракційним складом, можна зробити припущення, що вказані зміни будуть зумовлені вмістом та співвідношенням різних фракцій білкової складової ВРС. Для перевірки цієї гіпотези було проведено фракціонування білків досліджуваної сировини методом вибіркової розчинності за Осборном (табл. 2).

Таблиия 2. Фракційний склад білків досліджуваної сировини

\begin{tabular}{|c|c|c|c|c|c|}
\hline Сировина & Альбуміни & Глобуліни & Проламіни & Глютеліни & $\begin{array}{c}\text { Нерозчинний } \\
\text { осад }\end{array}$ \\
\hline $\begin{array}{c}\text { Борошно } \\
\text { пшеничне в/с }\end{array}$ & 5,7 & 12,1 & 38,0 & 26,9 & 17,3 \\
\hline СПК & 5,3 & 6,0 & 16,3 & 48,3 & 24,1 \\
\hline ІСБ & 16,0 & 47,1 & - & 20,6 & 16,3 \\
\hline ІГБ & 19,1 & 55,2 & - & 18,1 & 7,6 \\
\hline ІРБ & 11,9 & 36,1 & - & 33,2 & 18,8 \\
\hline
\end{tabular}

Наведені у таблиці дані свідчать про суттєві відмінності у фракційному складі білків пшеничного борошна, СПК (одержаної з пшениці) та бобових культур (гороху і сої). Останні не містять проламінів і мають удвічі менший вміст глютелінів $(18,1 . .20,6 \%)$, але до складу їх білків входить утричі більше водорозчинної фракції (альбумінів) та у п'ять разів $(47,1 . .55,2 \%)$ більше солерозчинної фракції (глобулінів). Рисовий білок займає проміжне місце, також не містячи проламінів, але вміст інших фракцій наближається до білка пшениці. Саме відсутністю проламінової фракції та внесенням додаткової кількості глютелінів можна пояснити підвищення міцності клейковинного каркасу тіста. В подальшому це може негативно вплинути на структурно-механічні властивості замішаного тіста, що потребуватиме внесення відповідних змін у хід технологічного процесу та вибору необхідних технологічних параметрів.

Висновки. Використання ВРС $є$ перспективним шляхом підвищення харчової та біологічної цінності хлібобулочних виробів. Однак при цьому слід обов'язково враховувати особливості фракційного складу білків обраної сировини та їх вплив на клейковинний каркас тіста. Одним із можливих варіантів зниження негативного впливу ізолятів рослинних білків на структурно-механічні властивості тіста та якість готових виробів $є$ сумісне внесення ізолятів і СПК. Вивчення впливу запропонованих двокомпонентних композиції ВРС на кількість і якість клейковини показало, що кількість як нативної (сирої), так і сухої клейковини знижується на 1,5...3,5\% порівняно з передбачуваними (розрахунковими) значеннями: Також на $25 . .40 \%$ знижується гідратаційна здатність відмитої клейковини. Водночас спостерігається їі зміцнення за показниками ИДК (на 3...13 од. прил.). Поясненням цьому може бути особливість фракційного складу білків обраних ізолятів, які не містять проламінової фракції, але до складу яких входить значна кількість альбумінів (12...19\%) і глобулінів (у ВРС 3 бобових вони становлять близько половини усіх білків). 


\title{
ЛІТЕРАТУРА
}

1. Повноцінне харчування : інноваційні аспекти технологій, енергоефективного виробництва, зберігання та маркетингу : кол. моногр. / за ред. В.В. Свлаш, В.О. Потапова, Н. Л. Савицької ; Харк. держ. ун-т харч. та торг. — Х. : ХДУХТ, 2015. - 580 с.

2. Байрамов E.E. Поліпшувачі , що підвищують еластичність і знижують розтяжність клейковини і тіста // Харчова промисловість. - 2015. - № 18. - С. 13-18.

3. Simakhina $G$. New non-traditional sources of food protein / G. Simakhina, N. Naumenko, K. Yarosh // Ukrainian food journal. — 2015. — Vol. 4. Issue 3. - P. 453 - 459.

4. Омельченко К.Ю. Вирішення основних проблем вирощування сої як шлях забезпечення продовольчої безпеки країни // Наукові праці Національного університету харчових технологій. - 2016. - Т. 22, № 4. - С. 76-82.

5. Пащенко Л.П. Соя: состав, свойства и рациональное применение в АПК. Воронеж, 2007. - $200 \mathrm{c}$.

6. Карнаушенко Л.И. Практическое применение изолятов белка в хлебопечении / Л.И. Карнаушенко, Р.И. Шевченко // Хлебопродукты. — 2000. — № 9. - С. 19-20.

7. Хрулев А.А. Тенденции развития и экономические аспекты производства горохового протеина / А. А. Хрулев, Н. И. Бесчетникова, И. А. Федотов // Пищевая промышленность. - 2016. - № 4. - С. $24-29$.

8. Технохімічний контроль сировини та хлібобулочних і макаронних виробів : навчальний посібник / за ред. чл.-кор. В. І. Дробот. - К.: Кондор-Видавництво, 2015. - 958 с.

9. Дробот В.І., Арсеньєва Л.Ю., Білик О.А. Лабораторний практикум з технології хлібопекарського та макаронного виробництв: навч. посіб. - К. : Центр навчальної літератури, 2006. - 341 с.

\section{ВЛИЯНИЕ ИЗОЛЯТОВ РАСТИТЕЛЬНОГО БЕЛКА НА КЛЕЙКОВИННЫЙ КОМПЛЕКС ПШЕНИЧНОГО ТЕСТА}

\author{
В.Н. Махинько, А.В. Шаран, Л.А. Шаран, Л.Н. Черниш \\ Национальный университет пищевых технологий
}

В статье изучено влияние высокобелковых растительных добавок (изолятов и сухой пшеничной клейковины) на клейковинный комплекс теста из пшеничной муки первого сорта. Использованы белковые изоляты сои, гороха и риса. Установлено, что изоляты растительных белков, которые имеют высокую водопоглотительную способность, ухудшают процесс образования клейковины. Сравнивая расчетные и экспериментальные данные относительно количества сырой и сухой клейковины, обнаружили, что в обеих случаях опытные значения меньше расчетных. Также во всех образцах снижается гидратационная способность клейковины и повышается ее упругость. Для объяснения этих изменений был изучен фрракционный состав белковых веществ исследуемого сырья. Установлено сходство белковых фракций добавок из зернового и бобового сырья, однако изолят рисового белка не содержит проламинов, имеющихся в пшеничной муке.

Ключевые слова: белок, клейковина, соя, горох, рис, тесто, фракции. 


\title{
УДК 637.146
}

\section{USE OF SPICES AS A SOURCE OF ANTHOCYANINS}

\author{
N. Yushchenko, U. Kuzmyk, I. Mykoliv \\ National University of Food Technologies
}

\begin{tabular}{|c|c|}
\hline Key words: & ABSTRACT \\
\hline $\begin{array}{l}\text { spicy aromatic raw } \\
\text { materials, } \\
\text { sumach, } \\
\text { anthocyanins, } \\
\text { color extract }\end{array}$ & $\begin{array}{l}\text { Anthocyanins are a wide group of water-soluble vegetable } \\
\text { pigments that cause red, blue and violet coloration of fruits, } \\
\text { flowers, leaves and other parts of plants. The purpose of } \\
\text { research is to study the effect of extraction temperature on the } \\
\text { content of anthocyanins and color index of Sumachu extract. }\end{array}$ \\
\hline Article history: & Determination of the content of anthocyanins and the color \\
\hline Received 27.03.2018 & index were determined using an electrophotocolymer KFK-2MP. \\
\hline $\begin{array}{l}\text { Received in revised form } \\
21.04 .2018\end{array}$ & $\begin{array}{l}\text { The active acidity of the samples was measured using a } \mathrm{pH}-\mathrm{me}- \\
\text { ter/millivoltmeter, with a measurement range of } 0-14 \text { units. } \mathrm{pH} \text {. }\end{array}$ \\
\hline Accepted 31.05.2018 & The total dry matter content was determined by a refractometric \\
\hline $\begin{array}{l}\text { Corresponding author: } \\
\text { ukuzmik@gmail.com }\end{array}$ & $\begin{array}{l}\text { method based on the determination of the refractive index of light. } \\
\text { The expediency of using the sumach of spices in the form of } \\
\text { an extract on milk whey derived from the production of cheese } \\
\text { dairy products has been proved. The highest degree of extrac- } \\
\text { tion of extractives is achieved at a temperature of }(80 \pm 2)^{\circ} \mathrm{C} \text { with } \\
\text { a duration of } 5 \ldots 10 \text { minutes, with a hydromodule of } 1: 10 \text {. Con- } \\
\text { tent of extractive substances - } 5 \% \text {. } \\
\text { The influence of temperature of extraction on the content of } \\
\text { anthocyanins and the color of extract of dried fruits of sumachu } \\
\text { are investigated. It has been established that, under certain } \\
\text { extraction conditions, the anthocyanin content increases and } \\
\text { amounts to } 11.4 \mathrm{mg} / 100 \mathrm{~g} \text {, which causes a rich color of the } \\
\text { extract, the color index increased by approximately } 5 \text { times } \\
\text { compared with extraction at } 20^{\circ} \mathrm{C} \text {. } \\
\text { The change of color and the content of anthocyanins in the } \\
\text { extraction extract was studied in the process of extraction at } \\
\text { temperatures from } 20 \text { to } 95^{\circ} \mathrm{C} \text { : the effect of extraction tempe- } \\
\text { rature on the efficiency of extraction of anthocyanins has been } \\
\text { investigated; for maximal extraction and storage of anthocyanins, } \\
\text { the extraction temperature should not exceed } 80^{\circ} \mathrm{C} \text {; it is deter- } \\
\text { mined that the color of the extract does not depend on the active } \\
\text { acidity of the medium within the limits inherent to the dairy } \\
\text { products, and increases with the increase in the temperature of } \\
\text { extraction and the extra extraction of colorants. }\end{array}$ \\
\hline
\end{tabular}

DOI: $10.24263 / 2225-2916-2018-23-6$

\section{ВИКОРИСТАННЯ ПРЯНОЩІВ ЯК ДЖЕРЕЛА АНТОЦІАНІВ}

\author{
Н.М. Ющенко, канд. техн. наук \\ У.Г. Кузьмик, асистент \\ І.М. Миколів, канд. техн. наук \\ Національний університет харчових технологій
}

У статті доведено доцільність використання пряності сумах у вигляді екстракту на молочній сироватиі, отриманої від виробництва сиру кисломо-

(C) Н.М. Ющенко, У.Г. Кузьмик, І.М. Миколів, 2018 
лочного. Найбільший ступінь вилучення екстрактивних речовин досягається за температури $(80 \pm 2)^{\circ} \mathrm{C}$ з тривалістю процесу 5...10 хвилин при гідромодулі 1:10. Вміст екстрактивних речовин - 5\%. Досліджено вплив температури екстрагування на вміст антоціанів і кольоровість екстракту сухих плодів сумаху. Встановлено, за визначених умов екстрагування вміст антоціанів збільшується і складає 11,4 мг/100 г, що обумовлює насичений колір екстракту, показник кольоровості збільшився приблизно в 5 разів порівняно з екстрагуванням при температурі $20^{\circ} \mathrm{C}$.

Ключові слова: пряно-ароматична сировина, сумах, антоціани, кольоровість, екстракт.

Постановка проблеми. Велике значення при використанні пряно-ароматичної сировини в продуктах харчування $є$ те, що вони містять антоціани $[1 ; 2]$.

Антоціани або антоціаніни - широка група водорозчинних рослинних пігментів, що обумовлюють червоне, синє й фіолетове забарвлення плодів, квіток, листя та інших частин рослин. Антоціани, антоціанідіни та їхні глюкозидні форми є сильними антиоксидантами. Інтерес до антоціанів обумовлюється тим, що більшість із них зменшують ризик серцево-судинних захворювань. Завдяки своїй біологічній активності ці сполуки досить широко застосовуються у харчовій промисловості як натуральний барвник Е163 [3-5].

Одним із джерел антоціанів $є$ пряність сумах, плоди якого свій рубіновий колір отримали завдяки антоціаніновим пігментам. Сумах (Rhus) містить яблучну, лимонну, винну, янтарну, малеїнову, фумаролу та аскорбінову кислоти. До складу сумаху також входить ефірна олія, альдегіди, терпеноїди. Листя сумаху містить велику кількість дубильних речовин, основний відсоток з яких займає танін, а решта - похідні галової кислоти. Вміст ефірної олії до 3\%, головний компонент якої мірцен (до 52\%). Хоча сумах і містить доволі високу кількість ефірної олії, іiі компоненти мають слабковиражений аромат і не є домінуючими у формуванні смако-ароматичного профілю продукту [6].

Мета дослідження: вивчення впливу температури екстрагування на вміст антоціанів і показник кольоровості екстракту сумаху.

Матеріали і методи. Вміст антоціанів визначали за допомогою електрофотоколориметра КФК-2МП за довжини хвилі 530 нм. Покази оптичної густини множили на перерахунковий коефіцієнт $(K=1056,7)$ і отримували вміст забарвлюючих речовин [7;8].

Визначення кольоровості в екстракті сумаху здійснювали за допомогою електрофотоколориметра КФК-2МП за довжини хвилі 560 нм. Кольоровість (Кл) в одиницях оптичної густини обчислювали за формулою:

$$
\text { Кл }=(10 \cdot Д 560) /(\mathrm{CP} \cdot d \cdot b),
$$

де Д560 - величина оптичної густини розчину, яку виміряли приладом за довжини хвилі 560 нм, од. опт. густ.; СР - масова частка сухих речовин у

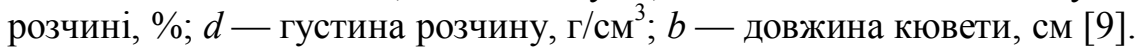

Активну кислотність зразків вимірювали із використанням $\mathrm{pH}-м е т р /$ мілівольтметра, 3 діапазоном вимірювання 0-14 од. $\mathrm{pH}$.

Загальний вміст сухих речовин визначали рефрактометричним методом, що грунтується на визначенні показника заломлення світла.

Результати досліджень. Попередніми дослідженнями визначено оптимальні технологічні параметри отримання екстракту сумаху: гідромодуль - 
$1: 10$, екстрагент - молочна сироватка; температура екстрагування $-(80 \pm 2)^{\circ} \mathrm{C}$; тривалість процесу 5-10 хв; розмір частинок до 2 мм.

Встановлено, що з підвищенням температури масова частка екстрактивних речовин підвищувалась, при цьому вагоме значення мала тривалість процесу за обраної температури. Тривалість екстрагування за температури $20^{\circ} \mathrm{C}$ протягом 10 хв давала такий же вихід екстрактивних речовин, як і нагрівання системи «сировина/розчиник» до температури $80^{\circ} \mathrm{C}$ без витримки. Найбільша масова частка екстрактивних речовин спостерігалась за таких параметрів процесу: температура $(80 \pm 2)^{\circ} \mathrm{C}$, тривалість екстрагування - протягом 5-10 хв.

3 огляду на те, що природні забарвлюючи сполуки сумаху формуватимуть органолептичні характеристики готового продукту, подальшими дослідженнями доцільно було визначити їх стійкість у процесі виробництва екстракту. Спочатку визначили вплив температури екстрагування на вміст антоціанів.

Встановлено, що вміст антоціанів 3 підвищенням температури до $80^{\circ} \mathrm{C}$ зростає і екстракт набуває насиченого малинового кольору (рис. 1), за температури $20^{\circ} \mathrm{C}$ вміст становить $4,2 \mathrm{мг} / 100$ г, за температури $80^{\circ} \mathrm{C}-11,4 \mathrm{мг} / 100$ г. При подальшому нагріванні до $95^{\circ} \mathrm{C}$ вміст антоціанів знижується, що можна пояснити їх частковою тепловою деструкцією.

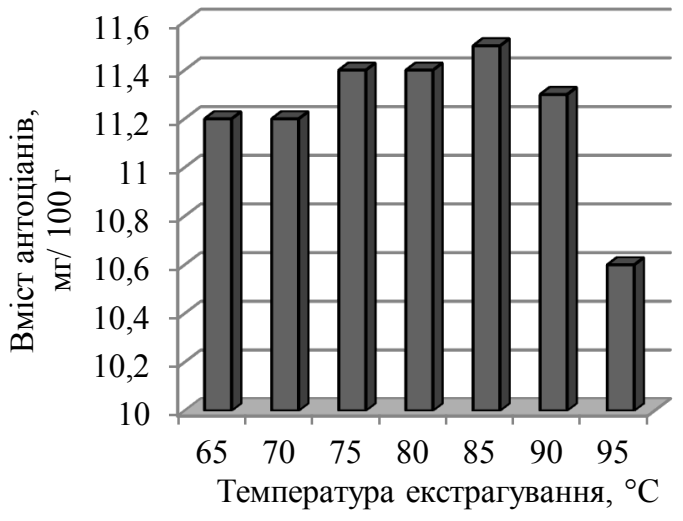

Рис. 1. Вплив температури екстрагування на ефективність вилучення антоціанів

Отже, не рекомендовано підвищувати температуру екстрагування вище $80^{\circ} \mathrm{C}$. Екстрагування слід проводити у діапазоні температур $65 \ldots 80^{\circ} \mathrm{C}$.

Підвищення температури й тривалий процес екстрагування за цих температур може також негативно позначатися на технологічних характеристиках екстракту та супроводжуватись втратою кольору.

Стійкість кольору в кислому середовищі також має значення, оскільки екстракт пропонується використовувати в технологіях паст кисломолочних. Тому на наступному етапі вирішено дослідити залежність показника кольоровості екстракту від температури екстрагування та кислотності середовища (рис. 2).

Для створення кислого середовища в межах активної кислотності 4,53,9 од.рН використовували харчову концентровану молочну кислоту.

Дані $з$ рис. 2 свідчать, що колір екстракту стає більш насиченим при підвищенні температури до $95^{\circ} \mathrm{C}$, показник збільшився приблизно в 5 разів, $30,2 * 10^{-3}$ до $1,0 * 10^{-3}$ одиниць оптичної густини. 


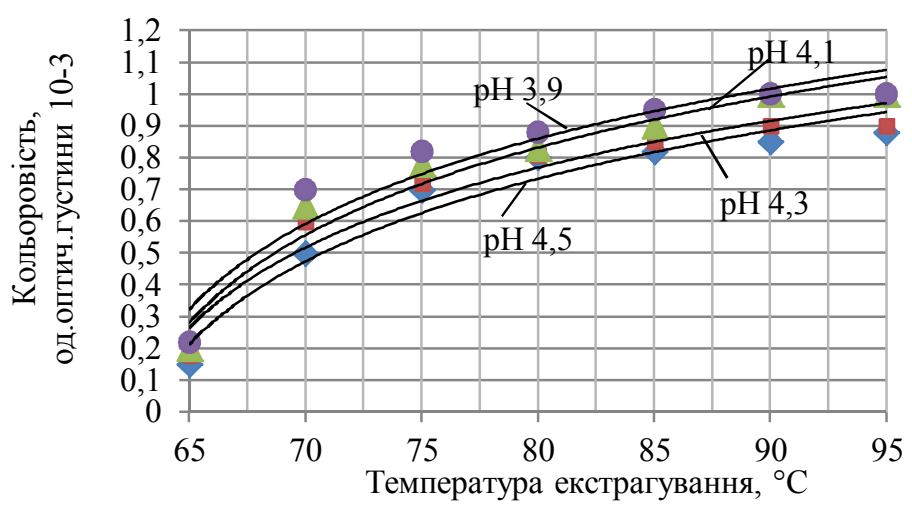

Рис. 2. Вплив температури екстрагування сумаху на показник кольоровості за різної активної кислотності

При знижені активної кислотності з 4,5 до 4,1 од.рН, що є в межах чинних нормативних документів для кисломолочних продуктів, показник кольоровості залишається без змін.

Тож сумах вирішено вводити до паст кисломолочних у вигляді екстракту за температури $(80 \pm 2)^{\circ} \mathrm{C} 3$ тривалістю екстрагування від 5 хв до 10 хв за гідромодуля 1:10, що забезпечить максимальне вилучення екстрактивних речовин $\mathrm{i}$ мінімальні втрати, у тому числі антоціанів.

Висновки. Вивчено зміну забарвлення та вміст антоціанів в екстракті сумаху в процесі екстрагування за температур від 20 до $95^{\circ} \mathrm{C}$ :

- досліджено вплив температури екстрагування на ефективність вилучення антоціанів, для максимального вилучення та збереження антоціанів температура екстрагування не повинна перевищувати $80^{\circ} \mathrm{C}$;

- визначено, що показник кольоровості екстракту не залежить від активної кислотності середовища в межах, властивих для кисломолочних продуктів, i збільшується із підвищенням температури екстрагування та за рахунок додаткового вилучення забарвлюючих речовин.

\section{ЛІТЕРАТУРА}

1. Кальченко Я.А. Дослідження антоціанів у траві чини посівної / Я.А. Кальченко, O.I. Павлій // Товарознавчий аналіз товарів обмеженого аптечного асортименту : матеріали III наук.-практ. Internet-конф. з міжнар. участю, 15 квіт. 2016 р. — Х. : Вид-во НФаУ, 2016. - C. 12.

2. Примак P. Антоціани відкривають свої таємниці / Р. Примак // Фармацевт практик. - 2014. - № 3. - С. 16-17.

3. Семенченко O.M. Дослідження якісного складу антоціанів суцвіть рослин роду Salvia L. / O.M. Семенченко, О.О. Цуркан, О.А. Коробльова, О.В. Бурмака // Фармакологія та лікарська токсикологія. - 2013. — № 3(34). - С. 63-66.

4. Ломова Т.С. Цветометрическое количественное определение антоциановых пигментов в спиртовых и водных растворах / Т.С. Ломова // Пиво и напитки. - 2008. № $1 .-$ C. $42-44$.

5. Гостинцев Д.А. Антоцианы плодов некоторых видов рода бузина / Д.А. Гостинцев, В.И. Дейнека, В.И. Сорокопудов // Научные ведомости Белгородского государственого университета. Серия: Медицина. Фармация. — 2011. — №16. - С. 21-26.

6. Дудченко Л.Г. Некоторые аспекты использования аромотерапии в практике врача / Л.Г. Дудченко, Т.П. Гарник, М.П. Данова. — К., 2007. — 46 с. 
7. Бондакова М.В. Разработка рецептуры и технологии производства косметических изделий с использованием экстракта винограда : дис. на соискание ученой степени канд. техн. наук: спец. 05.18 .06 «Технология жиров, эфирных масел ипарфюмерно-косметических продуктов» (технические науки) / М.В. Бондакова - Москва : МГУПП, 2014. - 171с.

8. Ignat I. A critical review of methodsfor characterisation of polyphenolic compounds in fruits andvegetables / I. Ignat, I. Volf, V. Popa // Food Chem. — 2011. — \# 4. — C. 1821-1835.

9. Кривовоз А.Г. Цветность - показатель качества продуктов / А. Г. Кривовоз, Ю.И. Сидоренко // Пищевая промышленность. — 2009. —№ 11. — С. 14.

\title{
ИСПОЛЬЗОВАНИЕ ПРЯНОСТЕЙ КАК ИСТОЧНИКА АНТОЦИАНОВ
}

\author{
Н.М. Ющенко, У.Г. Кузьмик, И.М. Мыколив \\ Национальный университет пищевых технологий
}

В статье доказана целесообразность использования пряности в виде экстракта на молочной сыворотке, полученной от производства творога. Наибольшая степень извлечения экстрактивных веществ достигается при температуре $(80 \pm 2)^{\circ} \mathrm{C}$ с выдержкой 5..10 минут при гидромодуле 1:10. Содержание экстрактивных веществ - 5\%. Исследовано влияние температуры на содержание антоцианов и показателя цветности экстракта сухих плодов сумаха. Установлено, что при определенных условиях экстрагирования содержание антоцианов увеличивается и составляет 11,4 ма/100 2, что обуславливает насыщенный цвет экстракта, показатель цветности увеличился примерно в 5 раз по сравнению с экстрагированием при температуре $20^{\circ} \mathrm{C}$.

Ключевые слова: пряно-ароматическое сырье, сумах, антоцианы, цветность, экстракт. 
УДК 664.314

\title{
RESEARCH OF FATTY ACIDS TOMATO SEEDS
}

\author{
O. Benderska, A. Bessarab \\ National University of Food Technologies
}

\begin{tabular}{|c|c|}
\hline & $\begin{array}{r}\text { ABSTRACT } \\
\end{array}$ \\
\hline $\begin{array}{l}\text { tomatoes, } \\
\text { seeds, } \\
\text { canning, } \\
\text { fatty acids, } \\
\text { chromatography, } \\
\text { food technology }\end{array}$ & $\begin{array}{l}\text { The article analyzes the state of the tomato-processing } \\
\text { industry and found that tomatoes are a promising raw material } \\
\text { for industrial processing due to their chemical and biological } \\
\text { value and the possibility of cultivation in all regions of Ukraine. } \\
\text { The value of waste of tomato production is determined and the } \\
\text { world experience in tomato shredder processing and seeds has }\end{array}$ \\
\hline $\begin{array}{l}\quad \text { Article history: } \\
\text { Received 03.04.2018 } \\
\text { Received in revised form } \\
\text { 05.05.2018 } \\
\text { Accepted } 04.06 .2018\end{array}$ & $\begin{array}{l}\text { been analyzed. The analytical review found that tomato seed } \\
\text { contains a wide range of biologically active substances, there- } \\
\text { fore, it is inappropriate to use classical tomato processing, } \\
\text { which does not involve the use of the potential of secondary } \\
\text { tomato raw materials. }\end{array}$ \\
\hline $\begin{array}{l}\text { Corresponding author: } \\
\text { olga_benderska@ukr.net }\end{array}$ & $\begin{array}{l}\text { The object of further researches is the seeds of tomatoes of } \\
\text { technical and biological maturity remaining after the production } \\
\text { of tomato products. For the analysis of the potential of tomato } \\
\text { seed use in food technology, the content of the main nutrients of } \\
\text { the seeds is determined and its fatty acid composition is } \\
\text { analyzed. Studies have shown that tomato seeds are an excellent } \\
\text { source of ingredients such as carotenoids, proteins, sugars, fi- } \\
\text { bers, waxes and oils. At the same time, trans isomers are absent } \\
\text { among fatty acids, and the ratio between unsaturated omega-3 } \\
\text { and omega- } 6 \text { acids in the seeds corresponds to the latest } \\
\text { recommendations regarding the compliance of diets with the } \\
\text { principles of balanced nutrition. } \\
\text { As a result of research in tomato seeds, } 21 \text { fatty acids were } \\
\text { identified. In the analyzed samples contained } 47,72 \% \text { polyunsa- } \\
\text { turated tomato seeds of technical maturity and } 50,96 \%- \\
\text { biological maturity. In the lipophilic fraction of the seed among } \\
\text { the saturated acids, palmitic acid prevailed, its content from the } \\
\text { amount of } 21.56 \% \text { for tomatoes of technical maturity, and } \\
20.75 \% \text { for tomatoes of biotic maturation. Linoleic acid predo- } \\
\text { minated among polyunsaturated acids. }\end{array}$ \\
\hline
\end{tabular}

DOI: $10.24263 / 2225-2916-2018-23-7$

\section{ДОСЛІДЖЕННЯ ЖИРОКИСЛОТНОГО СКЛАДУ ТОМАТНОГО НАСІННЯ}

\author{
О.В. Бендерська, аспірант \\ О.С. Бессараб, канд. техн. наук \\ Національний університет харчових технологій
}

У статті проаналізовано стан томатопереробної галузі та встановлено, що томати є перспективною сировиною для промислової переробки завдяки вмісту

(C) О.В.Бендерська, О.С. Бессараб, 2018 
біологічно активних речовин та можливості вирощування у всіх регіонах України. Встановлено, що томатне насіння містить широкий спектр біологічно активних речовин, які можуть бути придатними для використання в технологіях харчових продуктів. Крім того, насіння томатів є прекрасним джерелом таких компонентів, як каротиноїди, протеїни, иукри, волокна, воски та олії. При цьому серед жирних кислот відсутні транс-ізомери, а співвідношення між ненасиченими омега-3 та омега-6 кислотами в насінні відповідає останнім рекомендаціям щодо харчування населення зәідно з принципами нутріциології.

Ключові слова: томатопродукти, насіння томатів, консервування, поліненасичені жирні кислоти, хроматографрія, харчові технології.

Постановка проблеми. На сьогодні існує широкий асортимент харчових продуктів, що здатні задовольнити фізіологічні та біологічні потреби організму споживача. Останні дослідження харчових раціонів різних верств населення свідчать про те, що споживання найбільш цінних біологічно активних продуктів харчування за останні 10-15 років знизилось майже на 50\%. За даними медичних обстежень тільки 20\% населення можна вважати умовно здоровими; $40 \%$ в результаті харчових дефіцитів знаходиться в стані малоадаптації; $20 \%$ - в граничному стані між хворобою та здоров'ям. Тож більше половини населення потребує значного корегування харчування через зміну умов праці та побуту (гіподинамія і екологія) [1]. До шляхів подолання ситуації, що склалася, можна віднести використання біологічно цінної сировини для отримання продуктів, збалансованих за біохімічним складом та харчовою цінністю.

Грунтово-кліматичні умови України є досить сприятливими для вирощування багатьох видів овочевих культур, зокрема томатів відкритого грунту. Цікаво відмітити, що відповідно до рішення продовольчої і сільськогосподарської коміciї ООН (ФАО) Україну віднесено до числа держав, як потенційного експортера цієї продукції. Наразі Україна входить до 20 світових лідерів: Китай виробляє понад 34 млн т. томатів, США - 13 т, Туреччина і Індія - до 11 т, Сгипет понад 9 і Україна понад 1,5 млн т $[1 ; 2]$.

В Україні районовано більше 150 сортів і гібридів томатів, що відрізняються строками дозрівання, продуктивністю, типом, формою, забарвленням плодів, стійкістю проти хвороб, що дає змогу забезпечити придатними сортами і гібридами різні грунтово-кліматичні зони [3].

Причиною нарощування потужностей з вирощування є багатоцільове використання томатів як для споживання у свіжому вигляді, так і у різних продуктах переробки, а також наявності цінних нутрієнтів. Плоди томатів містять вітаміни B1, B2, B3, РP, K, C, а також каротиноїди (провітамін А), мінеральні речовини в доступній формі $\mathrm{Fe}, \mathrm{K}, \mathrm{Na}, \mathrm{Ca}, \mathrm{Mg}, \mathrm{S}$, I. Завдяки високому та збалансованому вмісту біологічно активних речовин щоденне вживання томатів сприяє м'якому регулювання обмінних процесів і діяльності шлунково-кишкового тракту, підсилюючи роботу інших залоз. До складу плодів томату входять яблучна і лимонна кислоти, які збуджують апетит, активізують процеси травлення та пригнічують шкідливу мікрофлору кишечника. У сучасних ринкових умовах для споживання у свіжому вигляді та для переробки доцільно відбирати сорти, які характеризуються високою врожайністю, стійкістю проти хвороб, придатністю до переробки і мають високі показники збалансованості хімічного складу [4].

При промисловій переробці томатної сировини для виробництва соків, томатної пасти та соусів утворюється велика кількість твердих відходів у вигля- 
ді вичавок, насіння, некондиційної сировини, які містять безліч корисних компонентів. Харчова та біологічна цінність вторинних томатних ресурсів, до яких відносять і томатне насіння, вивчалась українськими та зарубіжними дослідниками Б.В. Сгоровим, Г.І. Касьяновим, Н.І. Мосоловою, М.В. Ксенз та ін. [5-7]. Дослідниками рекомендується розглядати такі відходи, як побічний продукт харчового виробництва або сировину для переробки з метою використання в тваринництві, але перспективи отримання біологічно активних речовин (БАР) 3 подальшим використанням їх в якості інгредієнтів їжі залишаються недостатньо дослідженими.

Метою статті $є$ вивчення можливості використання вторинної сировини при розробці комплексної технології переробки томатів. Для цього на кафедрі технології консервування Національного університету харчових технологій спільно з Інститутом біохімії ім. О.В. Палладіна авторами було визначено вміст основних нутрієнтів томатного насіння, проаналізовано жирокислотний склад насіння томатів технічної та біологічної зрілості, досліджено перспективи його використання в технологіях харчових виробництв i, зокрема, при розробці технології комплексної переробки томатів.

Матеріали і методи. Об'єктом досліджень обрано насіння томатів технічної та біологічної зрілості. Хімічний склад томатного насіння встановлювали за допомогою загальновідомих методів: масова частка вуглеводів за допомогою поляриметричного методу, крохмаль за методом Еверса; клітковина — по Kurisner i Hanek; мінеральний склад - атомно-емісійною спектрометрією; вміст органічних кислот шляхом титрування [3-5; 8].

Досліджували ліпофільну фракцію насіння, отриману вичерпною екстракцією гексаном. Метод визначення жирнокислотного складу заснований на перетворенні тригліцеридів жирних кислот у метилові естери жирних кислот та газохроматографічному аналізі останніх [9]. Аналіз жирнокислотного складу ліпофільних фракцій здійснювали хроматографуванням метилових естерів жирних кислот на газовому хроматографі HRGC 5300 (Італія).

На хроматографі встановлювали такі параметри роботи: температура колонок термостата $-180^{\circ} \mathrm{C}$, температура випарника $-230^{\circ} \mathrm{C}$, температура детектора $-220^{\circ} \mathrm{C}$, швидкість потоку газу носія (азот) - $30 \mathrm{~cm}^{3} / \mathrm{xв,} \mathrm{об'єм}$ проби 2 мл ${ }^{3}$ розчину метилових естерів кислот у гексані. Ідентифікацію метилових естерів жирних кислот проводили за часом утримання піків порівняно зі стандартною сумішшю. Розрахунок складу метилових естерів проводили методом внутрішньої нормалізації. Як стандарта використовували зразки насичених і ненасичених метилових естерів жирних кислот фірми "Sigma". Метилові естери жирних кислот отримували за модифікованою методикою Пейскера, яка забезпечує повне метилювання жирних кислот. Для метилювання використовували суміш хлороформу 3 метанолом та кислотою сульфатною у співвідношенні 100:100:1. В скляні ампули відміряли 30-50 мл ліпофільного екстракту, приливали 2,5 мл метилюючої суміші та ампули запаювали. Потім їх поміщали до термостату з температурою $105^{\circ} \mathrm{C}$ на 3 год. Після закінчення метилювання ампули розкривали, вміст переносили в пробірку, додавали порошкоподібний сульфат цинку на кінчику скальпеля, приливали 2 мл води очищеної та 2 мл гексану для екстракції метилових естерів. Після ретельного збовтування і відстоювання, гексановий екстракт фільтрували і використовували для хроматографічного аналізу. 
Результати досліджень. Насіння томатів є прекрасним джерелом таких компонентів, як каротиноїди, протеїни, цукри, волокна, воски та олії. У Європі, наприклад, в 2015 р. було перероблено 10 мільйонів тонн томатів. Тверді відходи у вигляді вичавок 3 шкірки і насіння ( $2 \%$ від ваги вихідної сировини) склали 200 тисяч тонн. Основні БАР, що містяться в насінні та вичавках, - це лікопін, рослинні волокна, томатна олія, ензими. 3100 кг відходів томатного виробництва можна отримати 75 кг рослинних волокон, 4 кг олії і 3 кг воску, вилучити близько 110 мг лікопіну — потужного антиоксиданту, який зменшує ризик серцево-судинних захворювань, має протипухлинну та імуностимулюючу дію, використовується, як натуральний харчовий барвник. Аналіз даних щодо хімічного складу насіння томатів наведено в табл. 1.

Табличя 1. Хімічний склад насіння томатів, \% СР

\begin{tabular}{|c|c|}
\hline Показник & Значення \\
\hline Білок & $36,26 \ldots 37,07$ \\
\hline Ліпіди, в т. ч. & $37,44 \ldots 38,30$ \\
фосфоліпіди & $1,42 \ldots 1,45$ \\
\hline Мінеральні речовини, & $3,28 \ldots 3,35$ \\
\hline Вуглеводи & $30,14 \ldots 30,83$ \\
\hline Клітковина & $17,52 \ldots 17,92$ \\
\hline Каротиноїди & $0,018 \ldots 0,019$ \\
\hline Токофероли, в т. ч. & $0,072 \ldots 0,073$ \\
$\alpha$ 一 томатин & $0,028 \ldots 0,030$ \\
\hline
\end{tabular}

Аналіз хімічного складу томатного насіння свідчить про його високу харчову та біологічну цінність завдяки високому вмісту протеїну та ліпідів. Крім того, в томатному насінні містяться такі біологічно активні речовини, як токоферол та $\alpha$-томатину, які мають антиоксидантну та протипухлинну дію.

За два останніх десятиліття накопичено великий обсяг наукових даних, що вказують на важливу роль поліненасичених жирних кислот (ПНЖК) у реалізації численних фізіологічних і біохімічних процесів в організмі, що вказує на необхідність вивчення фактичного споживання з їжею $\omega-3$ і $\omega-6$ жирних кислот, ïx оптимальному рівні в раціоні, необхідному для забезпечення адекватного росту і розвитку.

Результати проведених досліджень наведені в табл. 2.

Таблиия 2. Жирокислотний склад насіння томатів

\begin{tabular}{|c|c|c|}
\hline Жирна кислота & $\begin{array}{c}\text { Насіння томатів технічної } \\
\text { стиглості, \% C }\end{array}$ & $\begin{array}{c}\text { Насіння томатів біологічної } \\
\text { стиглості, \% C }\end{array}$ \\
\hline 1 & 2 & 3 \\
\hline C14:0 & 0,37814 & 0,11219 \\
\hline C15:0 & 0,14795 & 0,06924 \\
\hline isoC16:0 & 0,16737 & 0,09063 \\
\hline $\mathrm{C} 16: 0$ & 21,56107 & 20,75644 \\
\hline $\mathrm{C} 16: 1$ & 0,86295 & 0,52893 \\
\hline $\mathrm{C} 16: 2$ & 0,27314 & 0,21643 \\
\hline $\mathrm{C} 17: 0$ & 0,27379 & 0,17228 \\
\hline $\mathrm{C} 17: 1$ & 1,30101 & 0,62897 \\
\hline isoC18:0 & 1,32274 & 0,94684 \\
\hline $\mathrm{C} 18: 0$ & 7,45303 & 5,92004 \\
\hline
\end{tabular}




\begin{tabular}{|c|c|c|}
\hline \multicolumn{2}{|c|}{ Продовження табл. 2 } \\
\hline 1 & 2 & 3 \\
\hline $\mathrm{C} 18: 1$ & 23,53947 & 24,04448 \\
\hline $\mathrm{C} 18: 2$ & 33,83710 & 39,38001 \\
\hline $\mathrm{C} 18: 3$ & 5,98324 & 3,95564 \\
\hline $\mathrm{C} 22: 0$ & 0,82807 & 0,64297 \\
\hline $\mathrm{C} 20: 1$ & 0,16670 & 0,10474 \\
\hline С21:0 & 0,11123 & 0,05920 \\
\hline С20:4 & 0,30494 & 1,64190 \\
\hline С20:0 & 0,71594 & 0,35592 \\
\hline С22:1 & 0,11557 & - \\
\hline С22:4 & 0,13882 & 0,06337 \\
\hline С24:0 & 0,51775 & 0,26506 \\
\hline Всього & 100 & 100 \\
\hline$\omega-6 / \omega-3$ & $2,55: 1$ & $4,16: 1$ \\
\hline МНЖК & 24,68469 & 24,67815 \\
\hline ПНЖК & 47,71713 & 50,96096 \\
\hline Ненасичені ЖК & 72,40182 & 75,63911 \\
\hline Насичені ЖК & 27,59818 & 24,36089 \\
\hline
\end{tabular}

У результаті дослідження в томатному насінні було встановлено наявність 21 жирної кислоти.

В аналізованих зразках містилось 47,72 \% поліненасичених для томатного насіння технічної зрілості та 50,96 \% — біологічної зрілості. У ліпофільній фракції насіння серед насичених кислот переважала пальмітинова кислота, іiі вміст від суми складав 21,56\% для томатів технічної зрілості, та 20,75\% для томатів біологічної стиглості. Серед поліненасичених кислот переважала лінолева кислота. Досліджувані зразки співвідносні за відсотковим вмістом лінолевої кислоти з льняною (15-30\%) [10] та арахісовою (12-35\%) оліями, перевищують iï вміст в оливковій (3-15\%), проте поступаються за цим показником кукурудзяній (38-48\%), соняшниковій (42-70\%) та соєвій (44-60\%) оліям. Вміст олеїнової кислоти в зразках томатного насіння наближається до кукурудзяної олії $(24-25 \%)$ та перевищує за значеннями вміст у бавовняній олії (18-19\%).

Відомо, що жирні кислоти $\omega-6$ і $\omega-3$ конкурують за метаболізацію ферментними системами і можуть заміщувати одна одну. Співвідношення $\omega-6 / \omega-3$ поліненасичених жирних кислот, що рекомендується Інститутом харчування РАМН, у раціоні здорової людини повинно становити 10:1, а для лікувального харчування - від 3:1 до 5:1. На підставі клінічних та експериментальних досліджень зарубіжних учених співвідношення кислот $\omega-6$ та $\omega-3$, що рекомендується, становить від 4:1 до 2:1 [11-12]. Результати експериментів показали, що в досліджуваних зразках томатного насіння таке співвідношення становить 2,55:1 для томатів технічної стиглості та 4,16:1 - біологічної, що дає змогу віднести олію 3 томатного насіння до цінних ессенціальних речовин і відзначити вищий вміст $\omega-3$ в насінні технічної стиглості, що відповідає останнім концепціям нутріциології.

Висновки. Для аналізу потенціалу використання томатного насіння в технологіях харчових продуктів визначено вміст основних нутрієнтів насіння та проаналізовано його жирокислотний склад. Проведені аналітичні дослідження встановили, що насіння томатів є прекрасним джерелом таких компонентів, як 
каротиноїди, протеїни, цукри, волокна, воски та олії. Серед ідентифікованих жирних кислот переважали ненасичені кислоти - лінолева, олеїнова, ліноленова. При цьому серед жирних кислот відсутні транс-ізомери, а співвідношення між ненасиченими омега-3 та омега-6 кислотами в насінні відповідає останнім рекомендаціям щодо харчування населення згідно 3 принципами нутріциології.

Отже, цінність хімічного складу томатного насіння визначається значним вмістом есенціальних жирних кислот, які відіграють ряд важливих біологічних функцій, виступають регуляторами обмінних процесів, зокрема беруть участь у ліпідному обміні, впливають на стан судинної стінки, протидіють вільнорадикальному окисленню. Тому томатне насіння можна віднести до перспективних видів харчової сировини.

\section{ЛІТЕРАТУРА}

1. Концепція державної науково-технічної програми «Біофортифікація та функціональні продукти на основі рослинної сировини на 2012-2016 роки». - Режим доступу : http://www1.nas.gov.ua/infrastructures/ Legaltexts/nas/2011/ regulations/OpenDocs/ 110608_189_concept.pdf

2. Heron S. Post-column addition as a method of controlling triacylglycerol response coefficient of an evaporative light scattering detector in liquid chromatography - evaporative light - scattering detection / S. Heron, M. Dreux, A. Tchapla // Journal of Chromatography. A. - 2004. - v7. 1035(2). - P. 221-225.

3. Raffaele De Caterina Fatty acids in cardiovascular disease. The New England journal of medicine 364(25). P. 2439-2450.

4. Журавель I.O. Вивчення ліпофільних сполук рослин родини Zingiberaceae / I.О. Журавель // Український медичний альманах. — 2010. — № 3. — С. 87-89.

5. Гаджиева А.М. Использование инновационных технологий комплексной переработки томатного сырья / А.М. Гаджиева, М.С. Мурадов, Г.И. Касьянов, Э.Ш. Исмаилов // Политематический сетевой электронный научный журнал Кубанского государственного аграрного университета. - 2012. 100. - С. 358-377.

6. Ксенз М.В. Рецептуры соусов на основе белково-томатной масляной пасты / Ксенз М.В., Бухтоярова 3.Т., Калманович С.А., Бугаец Н.В. // Известия высших учебных заведений. Пищевая технология. - (4). - С. 45-46.

7. Мосолова Н.И. Использование новых кормовых добавок в рационах лактирующих коров в зонах повышенного техногенного загрязнения / Н.И. Мосолова, А.С. Мякотных // Известия Нижневолжского агроуниверситетского комплекса: наука и высшее профессиональное образование. - 3. - С. 136-138.

8. Бурова Т.Е. Анализ и контроль пищевых производств / Под ред. А.Л. Ишевского. СПб. : СПбГУНиПТ, 2005. - 144 с.

9. Gaudin $K$. Retention behavior of unsaturated fatty acid methyl esters on porous graphitic carbon / K. Gaudin, P. Chaminade, A. Baillet. // Journal of Separation Science. 2004. - V. 27. - P. 41-46.

10. Silver ion reversed - phase comprehensive twodimensional liquid chromatography combined with mass spectrometric detection in lipidic food analysis / [L. Mondello, P.Q. Tranchida, V. Stanek, P. Jandera] // Journal of Chromatography. A. - 2005. — v9. - 1086(1-2). P. $91-98$.

11. О’Брайен Р. Жиры и масла. Производство, состав и свойства, применение. Пер. с англ. 2-го изд. - Сб. : Профессия, 2007. - 752 с.

12. What is the optimum w-3 to $\mathrm{w}-6$ fattyacid (FA) ratio of parenteral lipid emulsions in postoperative trauma? / B.J. Morlion [etc.] // Clinical Nutrition. — 1997. — Vol. 16 (Suppl. 2). P. 49 . 


\title{
ИССЛЕДОВАНИЕ ЖИРНОКИСЛОТНОГО СОСТАВА ТОМАТЫХ СЕМЯН
}

\author{
О.В. Бендерская, А.С. Бессараб \\ Национальный университет пищевых технологий
}

В статье проанализировано состояние томатоперерабатывающей отрасли, установлено, что томаты являются перспективным сырьем для промышленной переработки благодаря содержанию биологически активных веществ и возможности выращивания во всех регионах Украины. Установлено, что томатное семя содержит широкий спектр биологически активных веществ, которые могут быть пригодными для использования в технологиях пищевых продуктов. Кроме того, семена томатов являются прекрасным источником таких компонентов, как каротиноиды, протеины, сахара, волокна, воски и масла. При этом среди жирных кислот томатного масла отсутствуют транс-изомеры, а соотношение между ненасыщенными омега-3 и омега-6 кислотами в семенах соответствует последним рекомендацыям по питанию населения.

Ключевые слова: томатопродукты, семена томатов, консервирования, полиненасыщенные жирные кислоты, хроматографрия, пищевые технологии. 
УДК 637.238.2

\title{
INVESTIGATION OF TECHNOLOGICALLY-FUNCTIONAL PROPERTIES OF RED BEET POWDERS
}

\author{
O. Podkovko, H. Polishchuk \\ National University of Food Technologies
}

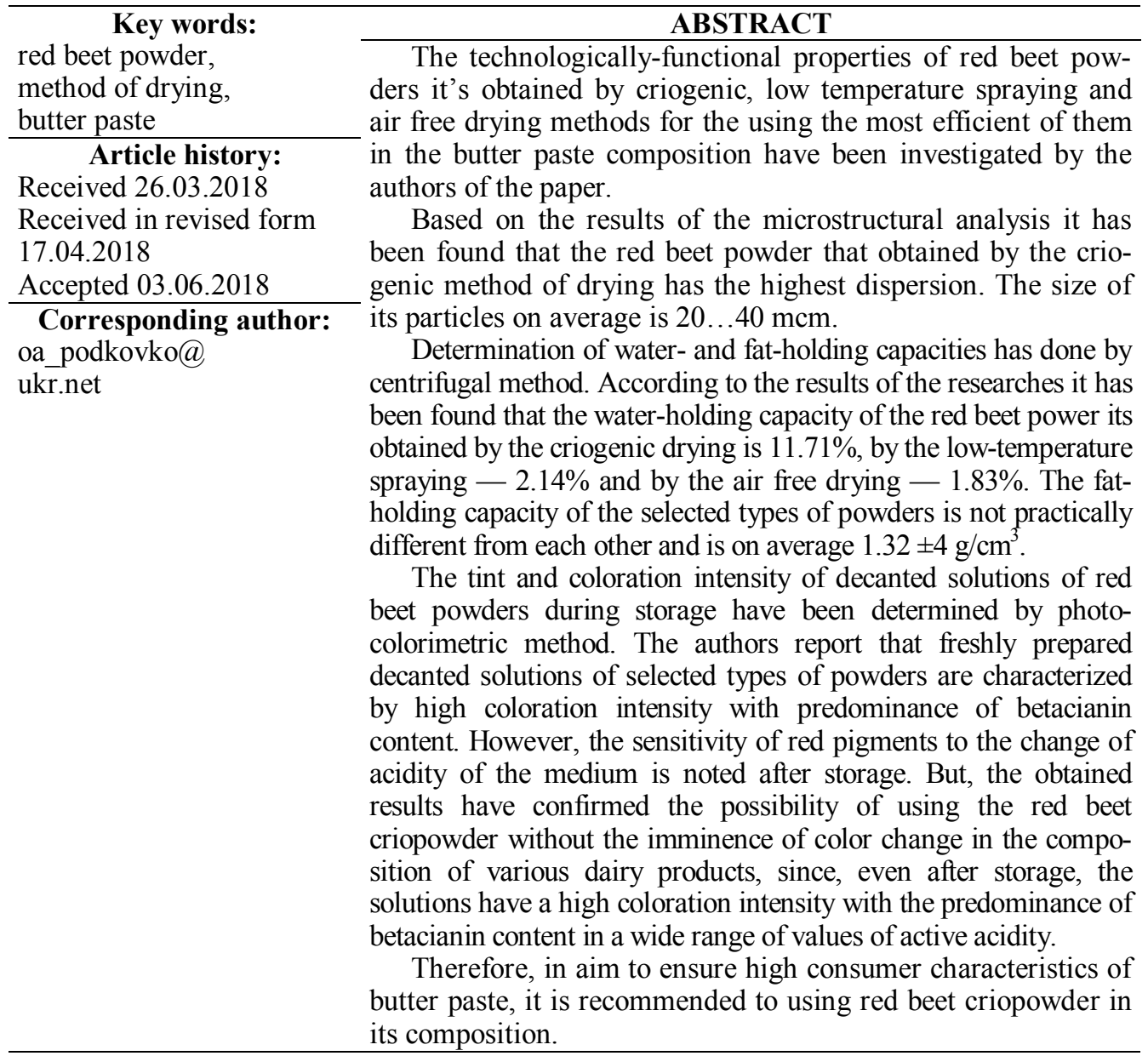

DOI: $10.24263 / 2225-2916-2018-23-8$

\section{ДОСЛІДЖЕННЯ ТЕХНОЛОГІЧНО-ФУНКЦІОНАЛЬНИХ ВЛАСТИВОСТЕЙ ПОРОШКІВ ІЗ БУРЯКА}

\author{
О.А. Подковко, канд. техн. наук \\ Г.є. Поліщук, д-р техн. наук \\ Національний університет харчових технологій
}

У статті досліджено технологічно-фрункціональні властивості порошків із буряка, що отримані за допомогою різних методів сушіння. Встановлено, що най-

(C) О.А. Подковко, Г.Є. Поліщук, 2018 
вищою дисперсністю характеризується кріопорошок з середнім розміром часточок у діапазоні значень 20...40 мкм. Виявлено, що вологоутримувальна здатність порошку з буряка кріогенного методу сушіння становить $11,71 \%$, низькотемпературного розпилювального - 2,14\%, вакуумного - 1,83\%. Жироутримувальна здатність обраних видів порошків незначно відрізняється одна від одної. Отримані результати визначення відтінку та інтенсивності забарвлення декантованих розчинів підтверджують можливість використання саме кріопорошку з буряка без загрози зміни забарвлення у складі різних видів молочних продуктів. З метою забезпечення високих споживчих характеристик масляної пасти рекомендовано у ії складі надавати перевагу використанню порошку з буряка кріогенного методу сушіння.

Ключові слова: порошок із буряка, спосіб сушіння, масляна паста.

Постановка проблеми. Відомо, що склад раціону харчування, особливо кількість та якість продуктів, які вживає людина, значно впливає на ії самопочуття і стан здоров'я. Так, у Данії у вересні 2014 р. Всесвітня організація охорони здоров'я внесла доповнення до попередньо розробленого «Плану дій в галузі харчових продуктів та харчування Свропейського регіону» на 2015-2020 роки, що в основному полягають у забезпеченні стійкого постачання населення безпечними і здоровими харчовими продуктами та розробленні їх нових видів 3 достатнім вмістом мікронутрієнтів для додаткового харчування [1]. Тому одним із першочергових завдань харчової промисловості, у тому числі маслоробної галузі, $\epsilon$ удосконалення технологій шляхом застосування у складі традиційних продуктів нових технологічно-функціональних інгредієнтів натурального походження.

На сьогодні науковці, які займаються питаннями розширення асортименту продукції маслоробної галузі, приділяють велику увагу розробленню й удосконаленню технології вершкової і масляної паст, що є аналогами вершкового масла і на виробництво яких витрачають менше молока-сировини за рахунок нижчої масової частки жиру готових продуктів. Так, під керівництвом проф. Топнікової (Росія) розроблено технологію вершкової і масляної паст 3 медом, какао, цикорієм, фруктово-ягідними, овочевими та грибними добавками, спеціями та прянощами. 3 метою формування стійкої і дрібнодисперсної структури до складу рецептур цих продуктів включають емульгатори та стабілізаційні системи [2]. У Білорусії впроваджено у виробництво шоколадну масляну пасту «До чаю» 3 масовою часткою жиру 40\%, до складу якої входять масло вершкове, вода питна, цукор білий, молоко сухе знежирене, какао-порошок, суміш стабілізаторів, сіль йодована, сорбат калію, регулятор кислотності лимонна кислота [3]. Раніше авторами статті розроблено склад масляної пасти жирністю 42\% 3 жиророзчинними емульгаторами вітчизняного виробництва [4]. Недоліком вказаного асортименту $є$ те, що у процесі виробництва паст застосовують хімічно модифіковані або синтезовані стабілізатори і емульгатори. Враховуючи сучасні рекомендації ВООЗ, перевагу слід віддавати використанню технологічно-функціональних інгредієнтів рослинного походження. Натуральні компоненти містять велику кількість біологічно активних речовин, які необхідні для здорового харчування населення, а також для профілактики та лікування багатьох захворювань.

Порошок із червоного столового буряка може бути застосований у технології масляної пасти як натуральна харчова добавка 3 функціонально-технологічними властивостями. Добавка містить вітаміни і мінеральні речовин, а також беталаніни - азотовмісні гетероциклічні пігменти, основними 3 яких є бетаїн і бета- 
нін. Вони володіють барвними та антиоксидантними властивостями, сприяють зміцненню капілярів, зниженню кров'яного тиску і вмісту холестерину у крові, поліпшенню жирового обміну, підвищенню життєдіяльності печінкових клітин [5]. Однак спосіб отримання порошку з буряка у подальшому може впливати на склад i властивості отриманої добавки. Тому актуальним є дослідження технологічнофункціональних властивостей порошків із буряка, що отримані різними методами сушіння з метою вибору найефективнішого виду у складі масляної пасти.

Мета статті полягає у дослідженні технологічно-функціональних властивостей порошків із буряка для застосування найефективнішого з них у складі масляної пасти.

Матеріали і методи. Об'єкт дослідження - порошки з буряка, що отримані за допомогою кріогенного (ЗАТ ВО «Гаммі», Росія), низькотемпературного розпилювального (Naturex, Швейцарія) та вакуумного (Naturex, Франція) методів сушіння.

Технологічно-функціональні властивості порошків із буряка характеризували за їх гранулометричним складом, вологоутримувальною та жироутримувальною здатністю, відтінком та інтенсивністю забарвлення декантованих розчинів.

Гранулометричний склад визначали за допомогою мікроскопа MICROmed XS-2610 шляхом підрахунку розмірів часточок порошків за збільшення у 150 разів. Дослідження вологоутримувальної та жироутримувальної здатностей проводили за загальновідомими методами центрифугування [6]. Відтінок та інтенсивність забарвлення декантованих розчинів порошків із буряка визначали колориметричним методом на електрофотоколориметрі марки КФК-2МП за довжин хвиль 490 нм і 540 нм. Порошки гідратували у дистильованій воді за різних температур і активної кислотності за співвідношення 1:40. Показник $\mathrm{pH}$ змінювали додаванням розчинів лугу $(\mathrm{NaOH})$ або кислоти $(\mathrm{HCl})$ різної концентрації до декантованого розчину порошку з буряка за співвідношення 1:10. Відтінок $\left(\mathrm{B}_{3}\right)$ та інтенсивність забарвлення $\left(\mathrm{I}_{3}\right)$ розраховували за формулою (1) $\mathrm{i}$ (2) відповідно [7]:

$$
\begin{gathered}
\mathrm{B}_{3}=Д_{490} / Д_{540} ; \\
\mathrm{I}_{3}=\left(Д_{490}+Д_{540}\right) n,
\end{gathered}
$$

де $Д_{490}, Д_{540}$ - оптичні густини декантованих розчинів порошків із буряка за довжин хвиль 490 нм і 540 нм відповідно в кюветі товщиною 10 мм; $n$ - ступінь розведення.

Результати досліджень. На якість харчових продуктів суттєво впливає ступінь дисперсності введених до їх складу добавок, оскільки саме тверді часточки розмірами понад 100 мкм можуть відчуватися органолептично і викликати вади консистенції продуктів. Зважаючи на вказане вище, досліджено гранулометричний склад порошків із буряка, що отримані за допомогою кріогенного (КС), низькотемпературного розпилювального (НРС) та вакуумного (BC) методів сушіння (рис. 1).

Відповідно до отриманих результатів (рис. 1), розміри основних фракцій часточок порошку з буряка КС, переважно овальної форми, знаходяться у діапазоні 20..40 мкм, НРС - 40..60 мкм, ВС - 40..80 мкм. Фракції розмірами більше 60 мкм для КС не перевищують 10\%, на відміну від інших його видів. 


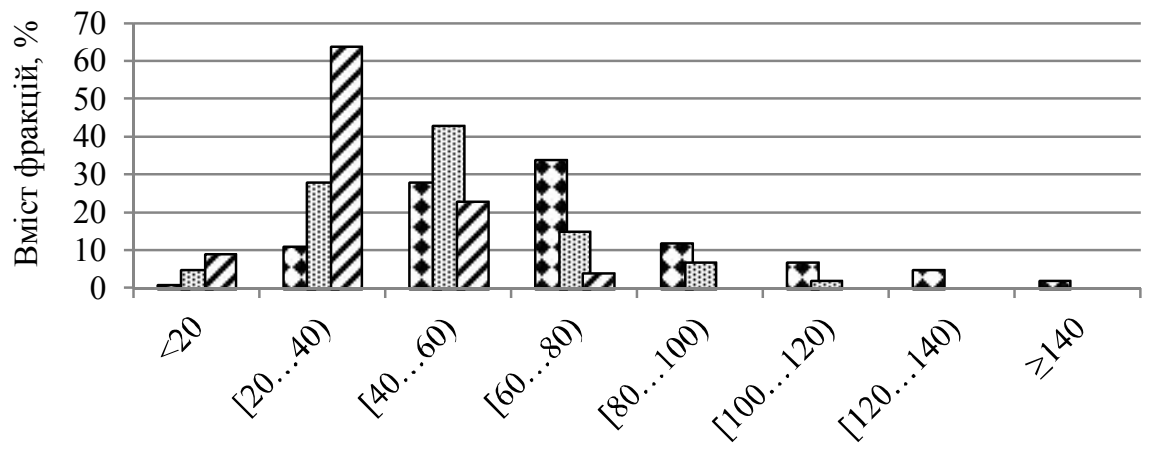

Розміри фракцій, мкм

由

Рис. 1. Гранулометричний склад обраних видів порошків із буряка

Для застосування вказаних порошків із буряка у складі масляної пасти, яка містить і жирову, і водну фази, необхідно дослідити їх вологоутримувальну (ВУЗ) і жироутримувальну (ЖУЗ) здатності. Результати дослідження ВУЗ і ЖУЗ обраних порошків із буряка наведено на рис. 2.

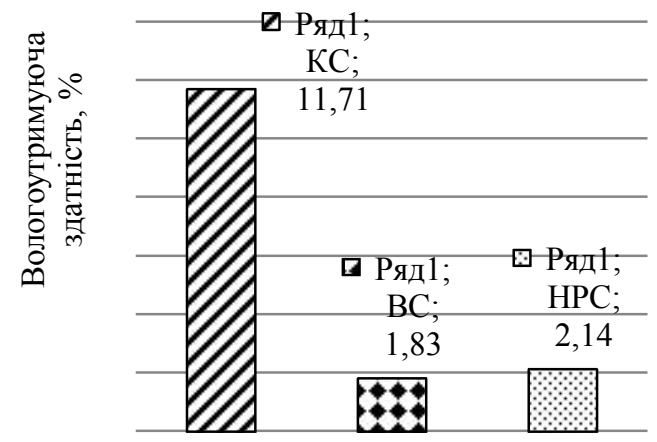

a)

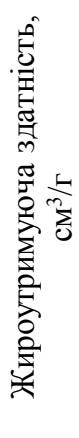

Рис. 2. Вологоутримувальна (а) і жироутримувальна (б)

\section{здатності обраних порошків із буряка}

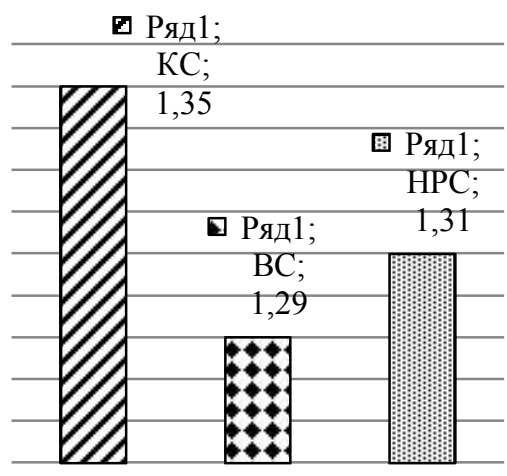

б)

Встановлено, що найвищу ВУЗ виявляє зразок КС (11,71\%), що через ефективне зв'язування вологи опосередковано підтверджує мінімальний вплив кріогенного сушіння на первинну структуру складових рослинних клітин. Слід відмітити, що надосадова рідина після центрифугування порошків із буряка має яскраворожеве забарвлення внаслідок переходу у розчинник природніх барвників антоціанів. Встановлено, що ЖУЗ порошків із буряка різних способів сушіння незначно відрізняється одна від одної.

Столовий буряк містить природні колоранти - беталаніни, які складаються 3 пігментів червоного (бетаціанінів) та жовтого (бетаксантінів) кольорів. Дані речовини обумовлюють червоне забарвлення різних відтінків порошку з буряка, i, відповідно, колір продуктів, у які їх вносять.

Відомо, що температурні режими оброблення й активна кислотність можуть негативно вплинути на інтенсивність і відтінок забарвлення рослинних пігментів 
у складі масляної пасти, у тому числі в процесі їі зберігання [7]. Тому на наступному етапі роботи досліджували вплив кислотності середовища на зміну інтенсивності та відтінку забарвлення декантованих розчинів порошків із буряка у процесі їх зберігання. Залежність інтенсивності забарвлення та відтінку свіжовиготовлених декантованих розчинів порошків із буряка від зміни $\mathrm{pH}$ середовища наведено на рис. 3 та 4 відповідно.

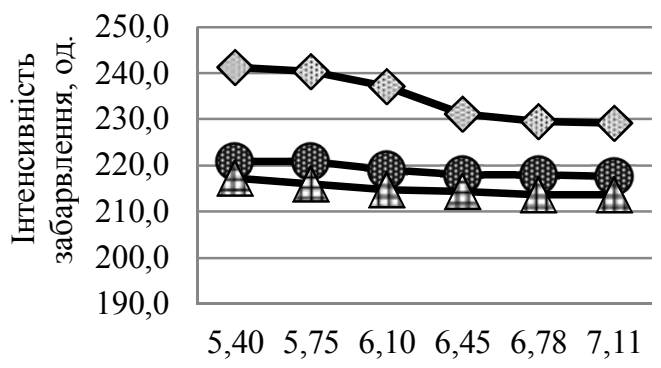

Активна кислотність, $\mathrm{pH}$

a)

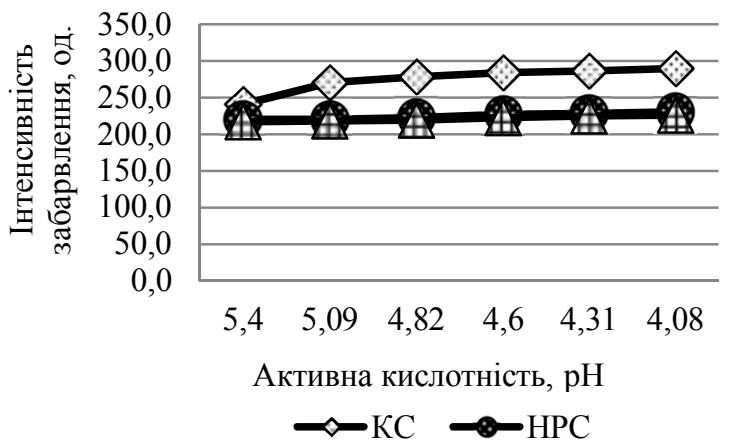

б)

Рис. 3. Залежність інтенсивності забарвлення свіжовиготовлених декантованих розчинів порошків із буряка від зміни $\mathrm{pH}$ : а) $\mathrm{NaOH}$; б) $\mathrm{HCl}$

Візуально свіжовиготовлені декантовані розчини порошків з буряка, що отримані за допомогою різних методів сушіння, мають яскраво червоне забарвлення за наявності у їх складі переважно пігментів червоного кольору. Це підтверджено результатами дослідження, наведеними на рис. 4, оскільки більшість значень відтінку менші за «1».

Підтверджено, що зміна кислотності середовища призводить до зміни інтенсивності забарвлення декантованих розчинів та їх відтінків. Так, за рахунок підкислення інтенсивність забарвлення підвищується, а відтінок зменшується, що вказує на переважання бетаціанінів у розчині. I навпаки, зміна активної кислотності у бік лужного середовища призводить до зменшення інтенсивності забарвлення, а отже, i підвищення вмісту бетаксантінів. За $\mathrm{pH}_{\text {середовища }}=4$ декантовані розчини порошків із буряка характеризуються найвищою інтенсивністю забарвлення і найбільшим вмістом червоних пігментів. Однак навіть за $\mathrm{pH}_{\text {середовища }}=7$ розчинам властиве яскраве червоне забарвлення. Зміна кислотності середовища у середньому в межах $\mathrm{pH}=(4 \ldots 7)$ не призводить до втрати червоного кольору отриманих розчинів. Слід зазначити, що порошок із буряка КС характеризується вищим показником інтенсивності забарвлення та нижчим 
значенням відтінку порівняно з порошками ВС і НРС, що вказує на переважання у його складі бетаціанінів.

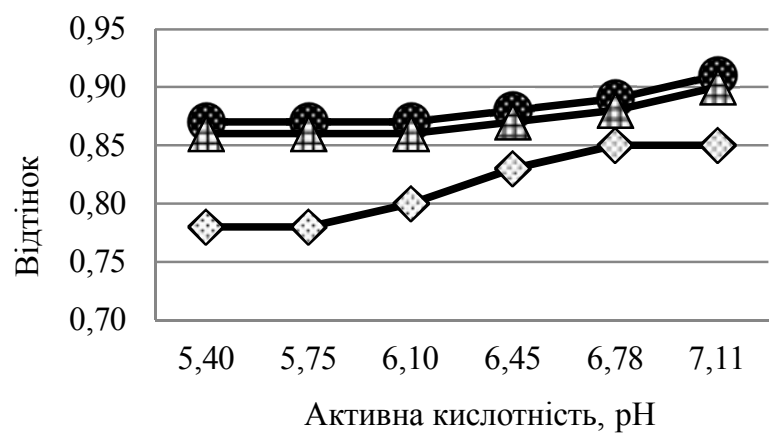

a)

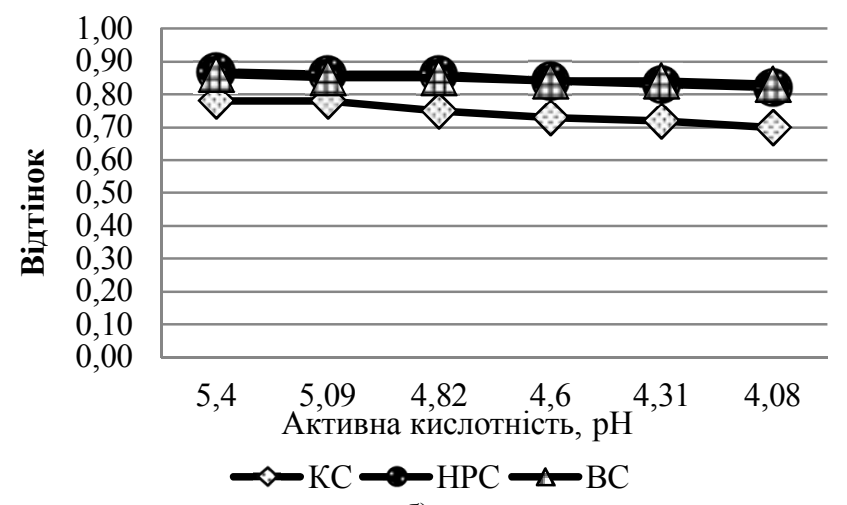

б)

Рис. 4. Залежність відтінку свіжовиготовлених декантованих розчинів порошків із буряка від зміни рН середовища: а) $\mathrm{NaOH}$; б) $\mathrm{HCl}$

Контрольні розчини зберігали впродовж 15 діб за температури $5^{\circ} \mathrm{C}$ без доступу кисню, що відповідає режимам зберігання масляної пасти згідно 3 нормативною документацією. Після вказаного витримування їх забарвлення візуально не змінилось. Варіювання активної кислотності середовища проводили подібно до умов свіжовиготовлених зразків. Залежність інтенсивності забарвлення і відтінку декантованих розчинів порошків із буряка від кислотності середовища після зберігання наведено на рис. 5 і 6 відповідно.

Дані, наведені на рис. 5 і 6, підтвердили чутливість червоних пігментів декантованих розчинів порошків із буряка до зміни активної кислотності середовища. Так, наприклад, відтінок порошку з буряка КС після зберігання вже за значення $\mathrm{pH}=7$ складає 0,99 , в той час як у свіжовиготовленого зразка - 0,85 . Відмічено тенденцію до збільшення вмісту жовтих пігментів у розчинах після зберігання з підвищенням кислотності середовища, на відміну від свіжовиготовлених зразків. Отримані результати вказують на можливість використання саме порошку з буряка КС без загрози зміни забарвлення у складі не тільки солодковершкової масляної пасти, а й для інших молочних продуктів 3 підвищеною кислотністю, оскільки навіть після зберігання розчини характеризуються високою інтенсивністю забарвлення із переважанням вмісту бетаціанінів у широкому діапазоні значень активної кислотності. 


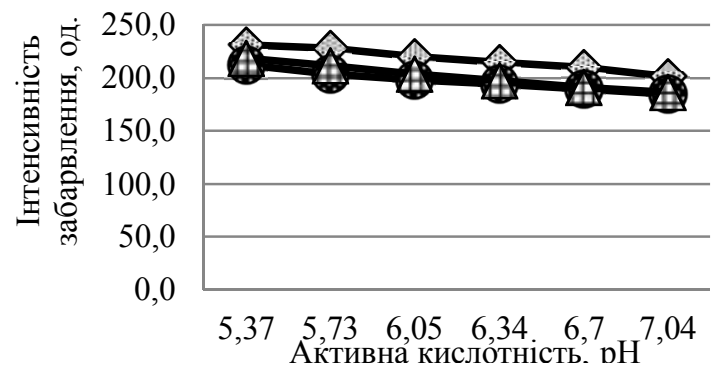

a)

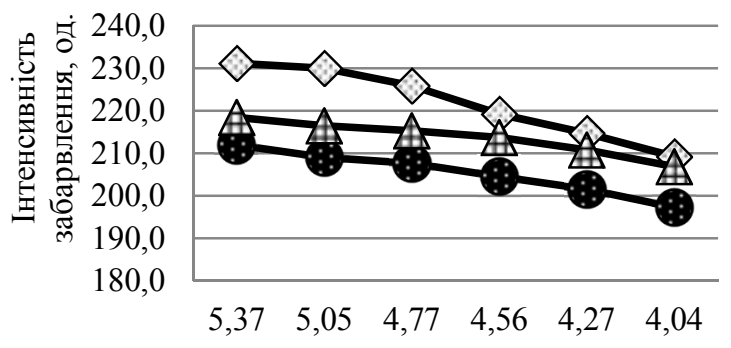

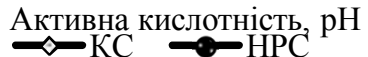

б)

Рис. 5. Залежність інтенсивності забарвлення декантованих розчинів порошків з буряка після 15 діб зберігання від зміни рН: а) $\mathrm{NaOH}$; б) $\mathrm{HCl}$
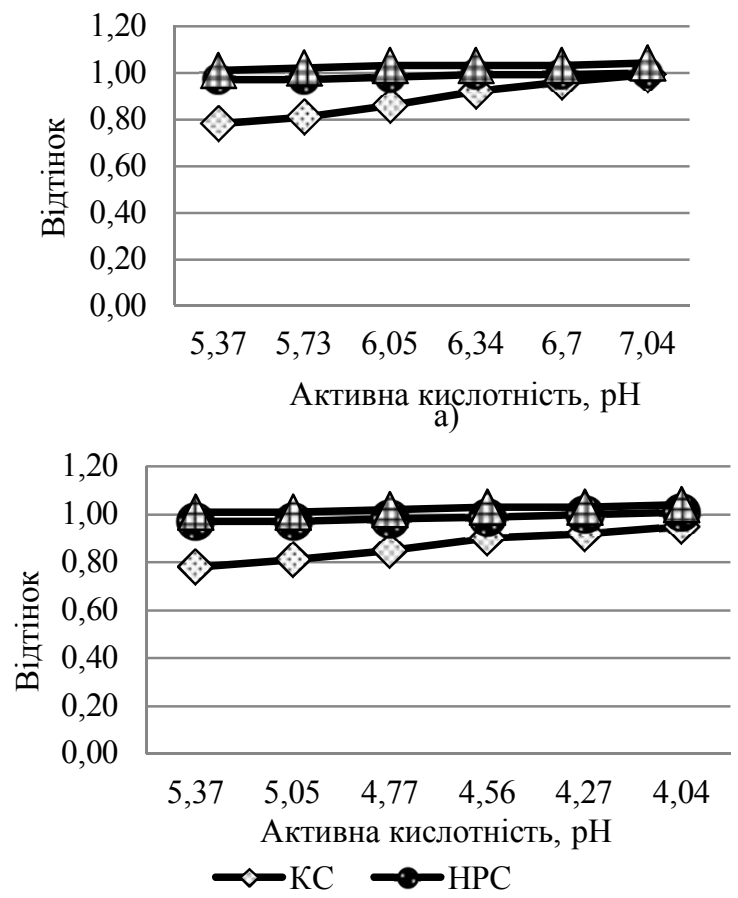

б)

Рис. 6. Залежність відтінку декантованих розчинів порошків із буряка після 15 діб зберігання від зміни рН середовища: а) $\mathrm{NaOH}$; б) $\mathrm{HCl}$ 
Отже, на основі проведеного комплексу досліджень у складі масляної пасти рекомендовано надавати перевагу використанню порошку з буряка, отриманого кріогенним методом сушіння.

Враховуючи отримані результати досліджень, у подальшому заплановано розробити асортимент молочних продуктів з низьким вмістом жиру, у тому числі масляної пасти, із використанням у їх складі кріопорошку з буряка як технологічно-функціональної добавки натурального походження.

Висновки. Встановлено, що спосіб отримання порошків із буряка суттєво впливає на їхні технологічно-функціональні властивості. Так, порошок із буряка кріогенного методу сушіння характеризується найвищими дисперсністю, вологоутримувальною здатністю та інтенсивністю забарвлення на відміну від порошків 3 буряка, що отримані за допомогою низькотемпературного розпилювального і вакуумного способів сушіння.

3 метою формування високих показників якості масляної пасти рекомендовано надавати перевагу використанню у іiі складі порошку з буряка кріогенного методу сушіння.

\title{
ЛIТЕРАТУРА
}

1. Шемета О. Функціональне харчування - новий підхід до здорового способу життя / О. Шемета, К. Дожук // Ліки України. — 2015. — № 1(186). — С. $24-27$.

2. Топникова E.B. Продукты маслоделия пониженной жирности для диетического питания / Е.В. Топникова, Т.А. Павлова, Ю.В. Никитина, Е.Н. Пирогова // Сыроделие и маслоделие. — 2016. - № 3. - С. 48-51.

3. Паста масляная шоколадная «К чаю». Технические условия Республики Беларусь: ТУ РБ 02906526.046-98. — [Введ. в дейст. 15.10.1999 р.]. — Беларусь : «Кобринский маслодельно-сыродельный завод», 1999. - 20 с.

4. Подковко О.А. Наукове обгрунтування складу солодковершкової масляної пасти / О.А. Подковко, Г.С.Поліщук, В.С. Гурєєва // Технічні науки та технології. — 2016. № 2(4). - C. 212-216.

5. Clifford T. The Potential Benefits of Red Beetroot Supplementation in Health and Disease / T.Clifford, G.Howatson, D.J.West, E.J. Stevenson // Nutrients. — 2015. — \# 7(4). — P. $2801-2822$.

6. Ганзенко В. Соєві боби. Вплив способу, ступеня їх подрібнення та термообробки на технологічні властивості водяних суспензій / В. Газенко // Харчова і переробна промисловість. - 2006. - № 10. - С. 24-26.

7. Dubkovetskyy I. Kinetics research of rise flour paste drying with beet colorant combined with energy supply / I. Dubkovetskyy, I. Malezhik, V. Pasichniy, I. Tymoshenko // Modern technologies in the food industry. - 2014. - P. 36-39.

\section{ИССЛЕДОВАНИЕ ТЕХНОЛОГИЧЕСКИ- ФУНКЦИОНАЛЬНЫХ СВОЙСТВ ПОРОШКОВ СО СВЕКЛЫ}

\author{
О.А. Подковко, Г.Е. Полищук \\ Национальный университет пищевых технологий
}

В статье исследованы технологически-фрункциональные свойства порошков со свеклы, полученные с помощью различных методов сушения. Установлено, что самой высокой дисперсностью характеризуется криопорошок со средним размером частиц в диапазоне значений 20...40 мкм. Выявлено, что влагоудер- 
живающая способность порошка со свеклы криогенного метода сушения составляет 11,71\%, низкотемпературного распылительного - 2,14\%, вакуумного - 1,83\%. Жироудерживающая способность избранных видов порошков незначительно отличается друг от друга. Полученные результаты определения оттенка и интенсивности окраски декантированых растворов подтверждают возможность использования именно криопорошка со свеклы без угрозы изменения окраски в составе различных видов молочных продуктов. C целью обеспечения высоких потребительских характеристик масляной пасты рекомендуется в ее составе отдавать предпочтение использованию порошка со свеклы криогенного метода сушения.

Ключевые слова: порошок со свеклы, способ сушения, масляная паста. 


\title{
УДК 664.681.2
}

\section{OBTAINING OF GLUTEN FREE WAFFLE SHEETS WITH BUCKWHEAT FLOUR BY MICROWAVE TREATMENT}

\author{
V. Dorokhovych, S. Litvynchuk, V. Nosenko \\ National University of Food Technologies
}

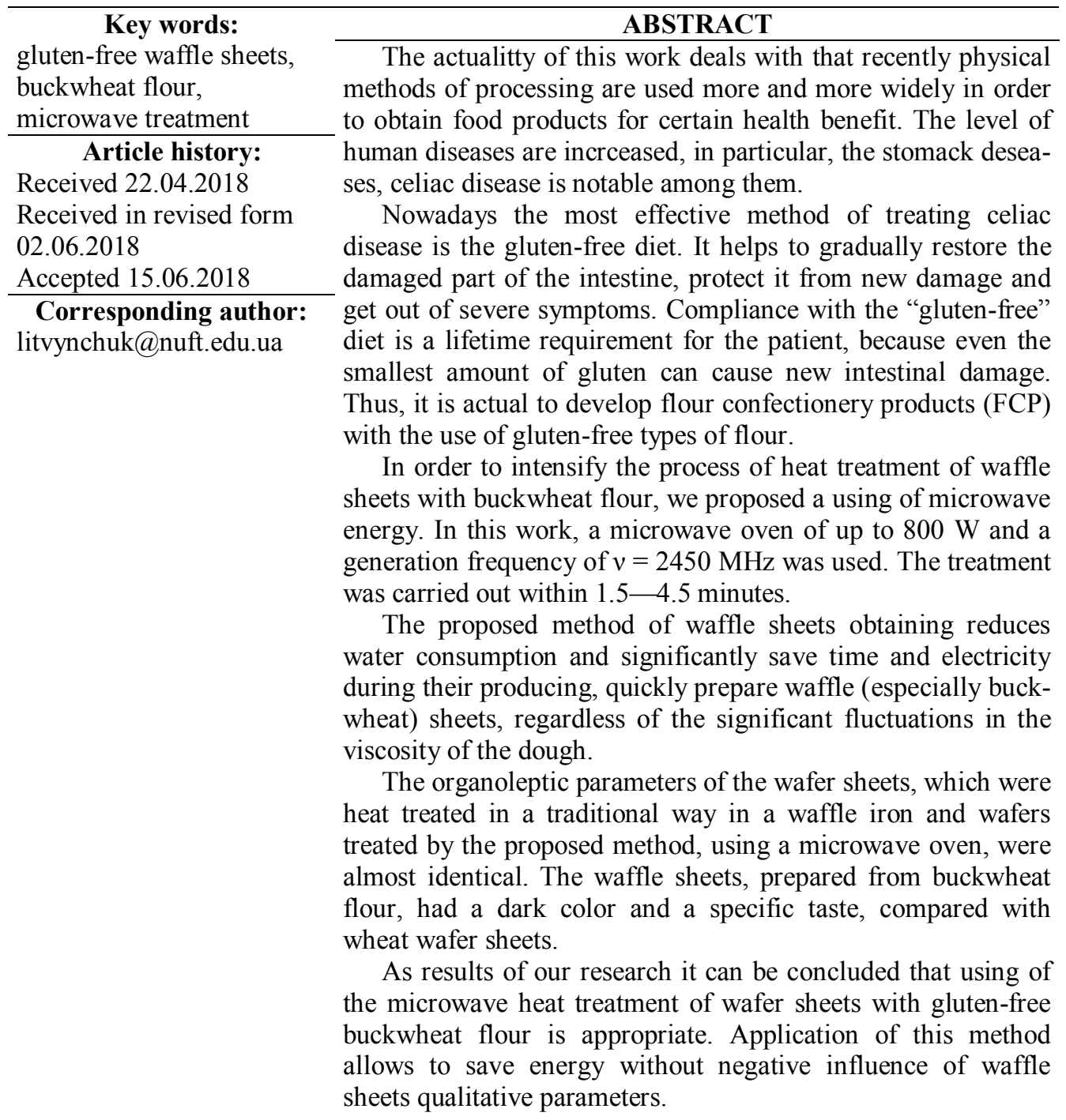

DOI: $10.24263 / 2225-2916-2018-23-9$

(C) В.В. Дорохович, С.І. Літвинчук, В.Є. Носенко, 2018 


\title{
ОДЕРЖАННЯ БЕЗГЛЮТЕНОВИХ ВАФЕЛЬНИХ ЛИСТІВ IЗ ГРЕЧАНОГО БОРОШНА ШЛЯХОМ МІКРОХВИЛЬОВОГО ОБРОБЛЕННЯ
}

\author{
В.В. Дорохович, д-р техн. наук \\ C.І. Літвинчук, канд. техн. наук \\ B.Є. Носенко, канд. фріз.-мат. наук \\ Національний університет харчових технологій
}

У статті запропоновано спосіб одержання безглютенових вафрельних листів із гречаного борошна за допомогою використання енергії мікрохвильового випромінювання. Експериментально доведено, що застосування такого способу дає можливість економити електроенергію при термообробці та сприяє отриманню вафрельних листів з необхідними органолептичними і структурними показниками.

Ключові слова: безглютенові вафельні листи, гречане борошно, мікрохвильове оброблення.

Постановка проблеми. Останнім часом все ширше застосовуються фізичні методи обробки з метою одержання харчових продуктів певного спеціального призначення. У світі поширюються захворювання гастродуоденальної зони, серед яких вагоме місце займає целіакія.

Целіакія (глютенова ентеропатія, хвороба Гі-Гертера-Гейбнера, нетоксичний спру, кишковий інфантилізм) - хронічне полісиндромне захворювання, яке характеризується неспецифічним ураженням слизової оболонки тонкого кишківника глютеном, який порушує харчову адсорбцію на ураженій ділянці. Захворювання на целіакію проявляється різними симптомами. Вважається, що целіакія - це системне захворювання, яке вражає різні органи і системи людини та пов'язане $з$ індивідуальною непереносимістю деякими людьми білка глютену. Глютен міститься в продукті, який утворюється 3 борошна злаків після виділення 3 нього крохмалю. Цей залишковий продукт являє собою суміш білків, які розрізняються за їх розчинністю й можливістю екстрагування. У різних злаках цей компонент має різну назву: у пшениці - глютен (гліадин), у вівсі — авенін, в ячмені — гордеїн, у житі - секалінін [1].

Дослідження фахівців-медиків доводять поліморфний характер захворювання на целіакію. Невиявлене своєчасно захворювання спричиняє розвиток широкого спектра автоімунних ускладнень у різних органах і системах організму. Захворювання на целіакію може проявлятись у різних видах: класичний, нетиповий, німий, прихований, потенційний [2-4].

До недавнього часу целіакія вважалася рідкісним захворюванням. Проте недавні дослідження, які були проведені спочатку в Свропі, а потім у США, показали, що реальна поширеність целіакії значно вища. На це захворювання страждає 0,3...1,0\% населення Землі. У більшості випадків целіакія поширена у країнах, де перевагу віддають виробам з пшеничного борошна. Дуже рідко целіакію виявляють у країнах Африки та Азії, тобто тих, де перевагу у харчуванні віддають більше сорго, рису, просу, ніж продуктам зі злакових культур [2; 3]. Важливим фактором у розповсюджені захворювання було виведення нових сортів пшениці 3 підвищеним вмістом клейковини, тобто глютену [2-5].

Симптоми целіакії і вік пацієнтів, в якому вони проявляються, дуже різноманітні. У дітей ці прояви залежать від того, коли дитина почала вживати глютен. 
Також впливає і кількість глютену в іжі. Слід зазначити, що чим довше дитина знаходиться на грудному вигодовуванні, тим пізніше і легше у неї проявляється целіакія. У дорослому віці прояви целіакії залежать від того, на скільки добре всмоктує поживні речовини невражена ділянка тонкої кишки.

Основним симптомом захворювання є порушення травлення. Але хвороба може проявитися і по-іншому. Наприклад, в однієї людини можуть бути діарея i болі в животі, тоді як у іншої - депресія або ейфорія й надмірна дратівливість.

Сдиним ефективним методом лікування целіакії на сьогодні є безглютенова дієта. Вона допомагає поступово відновити пошкоджену частину кишківника, захистити його від нового пошкодження і позбавитись важких симптомів. Дотримання «безглютенової» дієти — довічна вимога до хворого, тому що навіть найменша кількість глютену може викликати нові ушкодження кишечника.

Виходячи з цього, доцільним і актуальним є розроблення борошняних кондитерських виробів (БКВ) із застосуванням безглютенових видів борошна. До них належать: рисове, кукурудзяне, гречане та деякі інші види. Зазначені види борошна мають несхожий нутрієнтний склад і по-різному впливають на технологічні процеси виготовлення БКВ. Такі вироби вирізняються різноманітним груповим асортиментом, проте серед них значне місце займають БКВ на основі вафельних листів.

Аналіз хімічного складу безглютенових видів борошна показав, що в гречаному борошні міститься більше білків і жирів, ніж у рисовому та кукурудзяному. Це борошно характеризується значним вмістом вітаміну Е (що є позитивним як $з$ фізіологічної, так і технологічної точки зору), заліза, фосфору, магнію, цинку, які необхідні для нормального розвитку організму дитини та функціонування організму дорослої людини.

Науковцями встановлено, що тісто для печива на безглютенових видах борошна за структурно-механічними характеристиками суттєво відрізняється від тіста на пшеничному борошні [6]. Також доведено, що тістові маси на рисовому, гречаному, кукурудзяному борошні по-різному впливають на кінетику теромооброблення печива [7]. Подібні тенденції спостерігаються і для тістових мас кексів, бісквітів, мафінів.

Технологічний процес замішування традиційного вафельного тіста на пшеничному борошні повинен забезпечувати умови, які обмежують злипання окремих розрізнених частинок клейковини борошна. При зміні вологості тіста змінюється товщина гідратної оболонки навколо частинок клейковини. Зокрема, підвищений вміст вологи призводить до збільшення товщини гідратної оболонки навколо частинок клейковини, при цьому знижується агрегація і, відповідно, зменшується в'язкість тіста.

Вафельне тісто не підлягає тривалому зберіганню. В'язкість свіжоприготованого тіста безперервно зростає, і це порушує рівномірність дозування його у форми.

Мета дослідження: встановлення можливості використання мікрохвильового випромінювання для інтенсифікації процесу термооброблення вафельних листів, що забезпечить економію енергоресурсів 3 якісними органолептичними та структурно-механічними показниками вафельних листів на безглютеновому гречаному борошні.

Матеріали і методи. При проведенні досліджень були використані такі інгредієнти: 
- борошно пшеничне хлібопекарське вищого сорту (ГОСТ 46.004-99);

- борошно гречане (ТУ 15.6-00952737-006-2002);

- сіль кухонна (ДСТУ 3583-97);

- сода харчова (ГОСТ 5194-91);

- лецетин (ТУ 9146.006-00371185-93).

Процес виготовлення БКВ складається 3 різних технологічних операцій: (приготування тіста, формування, термооброблення тощо). Першою технологічною операцією, яка відіграє важливу роль у формуванні якісних показників готових виробів, $є$ приготування тіста.

Якісні показники вафельних листів аналізували за загальноприйнятими та спеціальними методиками [8]. Масову частку вологи у готових виробах визначали методом прискореного висушування на пристрої СЕШ-3М; хрупкість визначали на приладі Строганова; намочуваність вафельних листів встановлювали за кількістю поглинутої води.

Тісто для вафель істотно відрізняється від тіста для інших кондитерських виробів. Воно має сметаноподібну консистенцію, порівняно низьку в'язкість і вологість $65 \ldots 67 \%$. Саме така консистенція дає змогу отримати тонкі пористі вафельні листи.

Вафельні листи випікали в НВЧ-печі стандартної частоти генерації $v=$ $=2450$ МГц. Як форми для термооброблення вибирали радіопрозорі діелектричні матеріали (скло, кераміка). Мікрохвильова обробка здійснювалася за попередньо розробленою методикою $[9 ; 10]$.

Результати досліджень. Експериментально встановлено, що у разі виготовлення вафельного тіста на гречаному борошні традиційним способом вологість його потрібно збільшити до $75 \ldots 80 \%$. В іншому випадку таке тісто буде мати суцільну набухлу консистенцію, що ускладнить його відливання у вафельниці для подальшої термообробки. Це пов'язано з великою водопоглинальною здатністю гречаного борошна, яка становить 390\% (наприклад, водопоглинальна здатність пшеничного борошна становить 152\%). Також слід брати до уваги, що у разі вистоювання в'язкість вафельного тіста на гречаному борошні суттєво швидше зростає, ніж в'язкість вафельного тіста на пшеничному борошні. Підвищена вологість і в'язкість тіста на гречаному борошні призводить до збільшення тривалості його термооброблення, що має негативні економічні наслідки. У зв'язку з цим необхідно застосовувати такі способи термооброблення вафельних листів, які дали б змогу скоротити цей процес. Слід зазначити, що вафельний лист являє собою капілярно-пористе колоїдне тіло, а тому процес термооброблення можна описати на базі теоретичних основ процесу сушіння таких тіл.

Традиційний спосіб термооброблення вафельних листів здійснюється контактним способом шляхом розміщення тіста між двома пластинами. У процесі термооброблення тіста за короткий час видаляється велика кількість вологи (до $180 \%$ до маси сухої речовини тіста). Аналіз процесу вологовіддачі при традиційному способі дає можливість оцінити витрати тепла в процесі термооброблення вафельного тіста. На початковому етапі випікання підвід тепла повинен відбуватися максимально швидко, оскільки супроводжується найбільшою вологовіддачею. В подальшому, коли видаляється адсорбційно зв'язана волога, швидкість вологовіддачі значно зменшується, i, очевидно, доцільно зменшити витрати тепла. 
Зауважимо, що занадто інтенсивний підвід тепла може призвести до обвуглювання вафельного листа [8].

Якщо порівнювати вафельні листи, виготовлені із пшеничного та гречаного борошна, то слід відзначити, що за температури нагрівання форм в межах $160 \ldots 170^{\circ} \mathrm{C}$ тривалість процесу термооброблення суттєво відрізняється. Так, у разі сушіння традиційних вафельних листів на пшеничному борошні, вона була 2 хв. При цьому залишкова вологість вафельного листа складала $2 \%$. Тривалість термообробки вафельних листів на гречаному борошні за такої ж температури дорівнювала 2,5 хв, тобто на 25\% більша.

3 метою інтенсифікації процесу термооброблення вафельних листів на гречаному борошні нами запропоновано використання енергії мікрохвильового випромінювання. У цьому дослідженні використовувалась НВЧ-піч потужністю до 800 Вт і частотою генерації $v=2450$ МГц. Обробка проводилась протягом $1,5-4,5$ хв.

Завдання полягало в тому, щоб забезпечити виготовлення вафельних листів за умови економії часу й електроенергії, а також зменшення залежності виробництва від низької в'язкості тіста та небезпеки іiі збільшення. Слід зазначити, що спосіб виготовлення вафельних листів включає розміщення тіста між двома формуючими поверхнями 3 відповідним притисканням верхньою із них та їх подальшим термообробленням. Особливістю способу є те, що тісто повинно розміщуватись між двома радіопрозорими формуючими поверхнями. Досліди показали, що найкращим метеріалом для цього є кераміка.

Саме НВЧ-хвилі, проходячи крізь діелектричні поверхні, швидко доносять енергію до тістової маси, прогріваючи іï в усьому об'ємі, і час випікання вафельного листа при цьому зменшується порівняно з традиційною електротехнологією. У випадку використання НВЧ-печі вдається обробляти більш в'язкі тістові маси, в яких міститься менша кількість води. А отже, час та витрати електроенергії на термооброблення листів додатково зменшуються. За час термооброблення, що складає менше 1,5 хв, вафельні листи завжди є сирими й прилипають до формуючих поверхонь, а за 4,5 хв - підгоряють. Притискання тіста верхньою формуючою поверхнею формує вафельний лист як потрібного рисунку тиснення, так і потрібної товщини, забезпечуючи можливість використання більш в'язкого тіста, ніж традиційне. Спосіб є оптимальним для використання тіста з підвищеною в'язкістю, порівняно з традиційною.

Використовували тісто на гречаному борошні, яке більш корисне, ніж рисове та кукурудзяне, та дозволене у харчуванні хворих на целіакію й цукровий діабет. Гречане тісто вологістю 75\% розмістили всередині НВЧ-печі потужністю 720 Вт між керамічними формуючими поверхнями з відповідним притисканням верхньою. Час термооброблення вафельних листів складав 2,0 хв. Це на $20 \%$ менше, ніж у стандартній електричній вафельниці (2,5 хв), що споживає 800 Вт електричної енергії. Отже, економія енергії складає (800 Вт $\cdot 2,5$ хв 720 Вт $\cdot 2$ хв) $\cdot 100 \% / 800$ Вт $\cdot 2,5$ хв $=28,0 \%$. Можна стверджувати, що запропонований спосіб виготовлення вафельних листів дає змогу зменшити витрати води та суттєво економити час та електроенергію при їх виготовленні, оперативно виготовляти вафельні (особливо, гречані) листи, незалежно від помітних коливань в'язкості тіста.

Результати досліджень при різних потужностях для наочності наведено в табл. 1. 
Таблиия 1. Термообробка вафельних листів на гречаному борошні традиційним i мікрохвильовим способами

\begin{tabular}{|c|c|c|c|c|c|}
\hline \multirow{4}{*}{ Показник } & \multicolumn{5}{|c|}{ Спосіб термооброблення } \\
\hline & \multirow{3}{*}{$\begin{array}{c}\text { Традиційна } \\
\text { вафельниця, } 800 \\
\text { Вт }\end{array}$} & \multicolumn{4}{|c|}{ НВЧ-піч } \\
\hline & & \multicolumn{2}{|c|}{$\begin{array}{c}\text { Тривалість } \\
\text { термооброблення, хв } \\
\text { за потужності }\end{array}$} & \multicolumn{2}{|c|}{$\begin{array}{c}\text { Відмінність від } \\
\text { традиційного } \\
\text { способу, \% }\end{array}$} \\
\hline & & $540 \mathrm{BT}$ & $720 \mathrm{BT}$ & $540 \mathrm{BT}$ & $720 \mathrm{BT}$ \\
\hline Тривалість, хв & 2,5 & 3,5 & 2,0 & $+53,2$ & -20 \\
\hline Спожита енергія, Вт · хв & 2,0 & 2,07 & 1,44 & $+3,5$ & -28 \\
\hline
\end{tabular}

За органолептичними показниками вафельні листи, термооброблення яких здійснювали традиційним способом, у вафельниці та запропонованим способом, за допомогою НВЧ-печі, були практично однакові. Слід відзначити, що вафельні листи, виготовлені з гречаного борошна, мали темнувате забарвлення та специфічний присмак, порівняно з пшеничними вафельними листами.

За вологістю та структурними показниками вафельні листи, термооброблення яких здійснювали НВЧ-хвилями, більше наближаються до відповідних показників вафельних листів на пшеничному борошні (табл. 2).

\section{Табличя 2. Вологість і структурні показники вафельних листів}

\begin{tabular}{|c|c|c|c|c|}
\hline \multirow{2}{*}{$\begin{array}{c}\text { Листи, } \\
\text { виготовлені на } \\
\text { борошні }\end{array}$} & \multirow{2}{*}{$\begin{array}{c}\text { Спосіб } \\
\text { термооброблення }\end{array}$} & Вологість, \% & Намочуваність, \% & Хрупкість, N \\
\hline пшеничному & у вафельниці & 2,0 & 91,0 & 6,4 \\
\hline \multirow{2}{*}{ гречаному } & у вафельниці & 2,2 & 95,3 & 5,5 \\
\cline { 2 - 5 } & НВЧ-хвилями & 2,1 & 93,1 & 6,1 \\
\hline
\end{tabular}

Висновки. Аналізуючи результати досліджень, можна зробити висновок, що застосування способу термооброблення вафельних листів на безглютеновому гречаному борошні за допомогою НВЧ-печі є доцільним, дає змогу економити енергоресурси без негативного впливу на якісні показники вафельних листів. Технічна значимість результатів досліджень підтверджена патентом на корисну модель [11].

\section{ЛІТЕРАТУРА}

1. Целіакія [Електронний ресурс]. — Режим доступу : http://proctolog.ua/ua/zabolevaniya/celiakiya.

2. Целіакія (глютенова ентеропатія) [Електронний ресурс]. — Режим доступу : http://webmed.com.ua/ua/zdorove_ot_a_do_ya/zabolevaniya/organy_picshevareniy/celiakiya_ glyutenovaya_enteropatiya.

3. Парфёено И.А. Системные проявления болезни кишечника // Клиническая медицина. - № 4. - 2001. - С. 9-11.

4. Наумова О.А. Непереносимість глютену - міф чи реальна проблема // Матеріали міжнародних науково-практичних конференцій «Технологічні аспекти підвищення конкурентоспроможності хліба і хлібобулочних виробів» та «Здобутки та перспективи розвитку кондитерської галузі». - К.: НУХТ, 2016. — 190 с.

5. Хоха Р.Н. Особенности питания детей с глютеновой энтеропатией. Актуальность проблемы на современном этапе: сб. докл. V Междунар. научно-практич. конф. [«Инновационные технологии в производстве пищевых продуктов»], (Минск, 5-6 окт. 2006 г.). — Минск, 2006. 
6. Дорохович А.М. Визначення адгезійних властивостей безглютенових борошняних тістових кондитерських мас // Хранение и переработка зерна. - 2005. — № 10. - С. 50-52.

7. Дорохович А.М. Дослідження кінетики прогріву тістових заготовок здобного безглютенового печива / А.М. Дорохович, О.В. Бабіч, В.І. Телечкун, М.В. Лазаренко // Вісник Харківського національного технічного університету сільського господарства ім. П. Василенка. - Харків, 2005. - Вип. 38. - С.190-196.

8. Драгилев А.И. Производство мучных кондитерских изделий / А.И. Драгилев, Я.М. Сазанаев. - М. : Дели, 2000. - 546 с.

9. Використання мікрохвильової обробки в технології переробки насіння ріпаку / Т.Т. Носенко, В.А. Кіщенко, Т.О. Кот [та ін.] // Наукові праці НУХТ. — 2013. — № 50. C. $124-128$.

10. Nosenko T. Effect of rape seeds microwave pretreatment on the composition and antioxidative properties of press rape oil / Tamara Nosenko, Irina Levchuk, Volodymyr Nosenko, Tamara Koroluk // Ukrainian Food Journal. — 2016. — Volume 5, Issue 1. — P. 7-15.

11. Патент на корисну модель № 102841 України, МПК (2015.01): A21D 8/00, A21B 5/00, А21B 5/02 (2006.01). Спосіб виготовлення вафельних листів / І.В. Тарасенко, С.I. Літвинчук, В.С. Носенко, В.В. Дорохович, О.В. Данько. — № u 2015 04110; заявл. 28.04.2015; опубл. 25.11.2015, Бюл. № 22.

\title{
ПОЛУЧЕНИЕ БЕЗГЛЮТЕНОВЫХ ВАФЕЛЬНЫХ ЛИСТОВ ИЗ ГРЕЧНЕВОЙ МУКИ ПУТЕМ МИКРОВОЛНОВОЙ ОБРАБОТКИ
}

\author{
В.В. Дорохович, С.И. Литвинчук, В.Е. Носенко \\ Национальный университет пищевых технологий
}

В работе предложен способ получения безглютеновых вафельных листов из гречневой муки с помощью использования энергии микроволнового излучения. Экспериментально доказано, что применение данного способа дает возможность экономить электроэнергию при термообработке и способствует получению вафрельных листов с необходимыми органолептическими и структурными показателями.

Ключевые слова: безглютеновые вафельные листы, гречневая мука, микроволновая обработка. 
УДК 664.123.4:621.374

\title{
METHODOLOGY OF THE DETERMINING OF STRUCTURAL AND MECHANICAL PROPERTIES OF SUGAR BEET TISSUE
}

\author{
T. Nykytiuk, V. Olishevskyi, E. Babko, A. Ukrainets, A. Bashta \\ National University of Food Technologies \\ O. Prokopiuk \\ «Teplocom», LLC
}

\begin{abstract}
Key words:
sugar beet cloth, extraction,

pressing, nanosized aluminum

hydroxide,

elasticity,

modulus of elasticity

Article history:

Received 23.04.2018

Received in revised form

21.05.2018

Accepted 06.06.2018

Corresponding author:

tarasnykytiuk@gmail.com

ABSTRACT
The aim of the research is to study the technique for determining the structural and mechanical properties of sugar beet tissue, taking into account the use of additional reagents in the extraction of sucrose. The modulus of elasticity of a fabric is an indicator characterizing its rigidity and the ability to resist deformation under the action of force. The maximum effective extraction of sucrose from sugar beet shavings can be achieved with a diffusion process in which the beet tissue has optimal strength and elasticity. The main criterion for determining the degree of quality of sugar beet tissue is its ability to restore its shape and elasticity under periodic compressive loads during the extraction processes and subsequent pressing in production conditions. The quantity that most accurately describes the quality of the beetroot tissue is precisely the modulus of elasticity. The obtained samples of beet tissue of cylindrical shape were subjected to heat treatment (extraction) in aqueous solutions of additional reagents at a temperature of $70-72^{\circ} \mathrm{C}$. During the research were used, solutions of ground natural gypsum $\mathrm{CaSO}_{4}$, weak base salt and strong acid $\mathrm{Al}_{2}\left(\mathrm{SO}_{4}\right)_{3}$ and nanosized aluminum hydroxide $\mathrm{Al}(\mathrm{OH})_{3}$ obtained by the method of underwater electrospark synthesis. In the course of the research, several series of experiments of the heat treatment and direct-flow extraction with a duration of 60 minutes were carried out with the addition of chemical reagents to the extractant, which interact with the beet tissue. It has been established that all additional reagents improve the elastic and structural properties of beet tissue, while nanosized aluminum hydroxide $\mathrm{Al}(\mathrm{OH})_{3}$ has shown that it is its presence in the solution of the additional reagent that guarantees high structural and mechanical properties of the beet tissue.
\end{abstract}

DOI: $10.24263 / 2225-2916-2018-23-10$

(C) Т.В. Никитюк, В.В. Олішевський, Є.М. Бабко, А.І. Українець, А.В. Башта, О.М. Прокопюк, 2018 


\title{
МЕТОДИКА ВИЗНАЧЕННЯ СТРУКТУРНО-МЕХАНІЧНИХ ВЛАСТИВОСТЕЙ БУРЯКОВОЇ ТКАНИНИ
}

\author{
Т.В. Никитюк \\ В.В. Олішевський, канд. техн. наук \\ Є.М. Бабко, канд. техн. наук \\ A.І. Українець, д-р. техн. наук \\ А.В. Башта, канд. техн. наук \\ Національний університет харчових технологій \\ О.М. Прокопюк, канд. техн. наук \\ TOB «Теплоком»
}

У статmі наведено й адаптовано видозмінену методику для визначення структурно-механічних характеристик тканини иукрового буряка в дифузійно-пресовому способі екстрагування сахарози з використанням додаткових реагентів. Встановлено, що використання додаткових реагентів сприяє покращенню пружних властивостей бурякової тканини, при цьому нанорозмірний гідроксид алюмінію $\mathrm{Al}(\mathrm{OH})_{3}$ показав у кінцевому результаті найкращі показники.

Ключові слова: бурякова тканина, екстрагування, пресування, нанорозмірний гідроксид алюмінію, пружність, модуль пружності.

Постановка проблеми. Традиційний дифузійно-пресовий спосіб вилучення сахарози з бурякової стружки відбувається при ії тепловому нагріванні з подальшим пресуванням та поверненням жомопресової води на екстрагування. Тому актуальними $є$ питання покращення структурно-механічних властивостей бурякової стружки, а саме: збереження цілісності структури ії тканини в процесі сокодобування [1].

Одним із сучасних напрямків покращення структурно-механічних характеристик бурякової тканини є застосування хімічних реагентів у процесі екстрагування [2; 3]. Відомо, що іони полівалентних металів $\left(\mathrm{Ca}^{2+}, \mathrm{Fe}^{2+}, \mathrm{Fe}^{3+}, \mathrm{Al}^{3+}\right.$ та ін.) здатні зв'язувати полісахариди клітинних стінок бурякової стружки в нерозчинні комплекси, знижуючи тим самим перехід нецукрів у дифузійний сік. Тому використання додаткових реагентів сприятиме збільшенню модуля пружності бурякової стружки i, як наслідок, підвищення іï транспортно-пресувальних характеристик.

На сьогодні відомий спосіб визначення структурно-механічних характеристик описаний у методиці [7; 9]. Сутність цієї методики полягає в закріпленні одного кінця вирізаного з коренеплоду зразка в затискний пристрій та відхилення вільного кінця зразка від вертикального положення. Наступним кроком $є$ вимірювання відстані відхилення вільного кінця зразка і розрахунок модуля пружності за формулою. Це досягається закріпленням на вільному кінці зразка пластини з магнітного матеріалу та розміщення його біля зразка електромагніту, підключеного до джерела струму, для притягання пластини до електромагніту. Потім за методикою визначають силу струму, що подається в котушку електромагніту, і силу тяжіння пластини залежно від встановленої сили струму та подальше використання величини значення сили тяжіння для розрахунку модуля пружності. Недоліками цієї методики є досить висока складність і виконання, як наслідок, невисока точність отриманих результатів модуля пружності з похибкою $5-7 \%$, особливо в зразках тканини частково знецукреного цукрового буряка. 
Мета дослідження: видозмінення, вивчення й адаптація методики визначення структурно-механічних характеристик бурякової тканини для оцінки ефективності використання додаткових реагентів у процесі екстрагування сахарози.

Матеріали і методи. Максимально ефективне вилучення сахарози з бурякової стружки може бути досягнуто при такому режимі дифузійного процесу, коли бурякова тканина має оптимальні показники міцності, пружності та ін. [4; 5].

Дослідження термохімічного впливу водних розчинів додаткових реагентів на структурно-механічні властивості бурякової тканини проводилися на лабораторній установці, представленій на рис. 1.

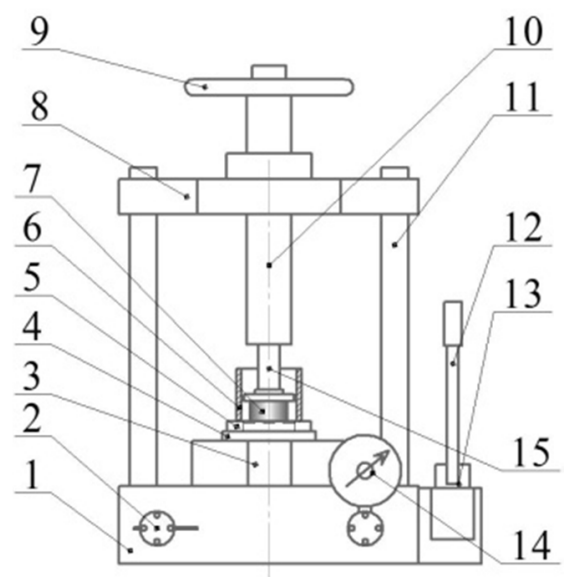

Рис. 1. Схема адаптованої лабораторної установки для дослідження структурномеханічних характеристик бурякової тканини: 1 - корпус; 2 - випускний гвинт; 3 - бак; 4 - п'ята; 5 - перфороване днище; 6 - знімна камера пресування; 7 - дослідний зразок; 8 - поперечина; 9 - ручка гвинта; 10 - притискний гвинт; 11 - стійка; 12 - ручка насоса; 13 - ручний насос; 14 - манометр. 15 - гідроциліндр

В основу роботи установки покладено принцип гідравлічного пресування. Лабораторний прес типу ПГР-10 (рис. 1) складається з корпусу 1, вертикальних стійок 11 , до яких кріпиться поперечина 8 . На «п'яті» 4 розміщена знімна камера пресування 6 з перфорованим днищем 5. Обертання ручки гвинта 9 притискає дослідний зразок до притискного гвинта 10 . За допомогою ручки насоса 12 нагнітається масло в гідроциліндрі 15 та здійснюється вертикальне підняття «п'яти» 4. Тиск контролюється манометром 14.

Використання даного інженерно-пресувального устаткування забезпечувало високий тиск ущільнення дослідного матеріалу до стану з незначним (наближеним до нуля) об’ємним вмістом газорідинної фази.

Під час пресування, залежно від структурних змін, що відбуваються в досліджуваному зразку дисперсного матеріалу заданого об'єму, можна умовно виділити чотири зони пресування (рис. 2) [5].

На I етапі пресування відбувається витіснення дисперсійного середовища (повітря, рідини) з об’єму матеріалу; процес характеризується незначним підвищенням тиску при значних переміщеннях пуансона.

На II етапі відбувається ущільнення безпосередньо дисперсної фази; процес характеризується зменшенням переміщення пуансона та поступовим підвищенням тиску. 
На III етапі проходить витіснення газорідинної фази з об'єму твердих часток матеріалу; процес характеризується значним підвищенням тиску при невеликих переміщеннях.

Ha IV етапі відбувається ущільнення складових дисперсної фази (руйнування клітин) при різкому підвищенні тиску та незначній величині переміщення пуансона.

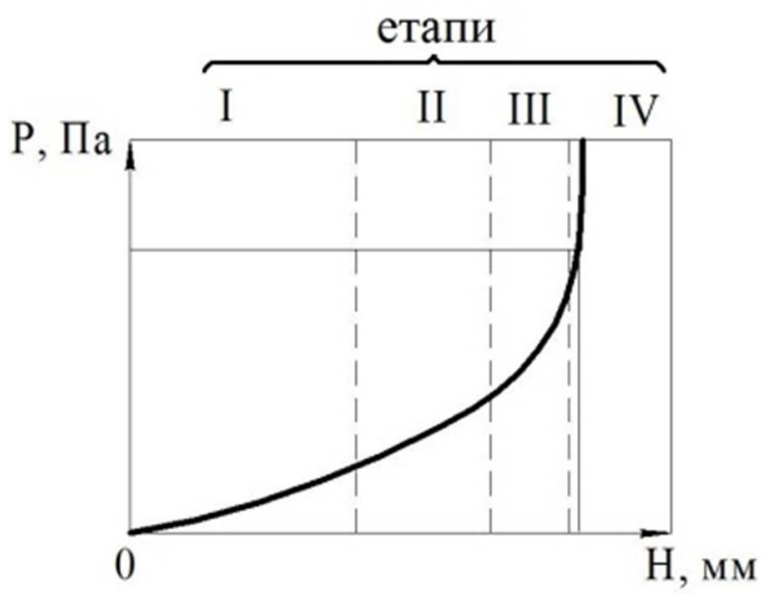

Рис. 2. Графік залежності тиску Р від лінійної деформації Н при пресуванні дисперсного зразка випробування

Дослідження структурно-механічних характеристик бурякової тканини проводили таким чином: із коренеплоду цукрового буряка отримували зразки циліндричної форми із заданими геометричними параметрами - діаметром 50 мм та висотою 25 мм. Кожен з отриманих зразків підлягав тепловій обробці у водних розчинах різних реагентів при температурі $70 \ldots 72^{\circ} \mathrm{C}$ при тривалості досліду 60 хв. Як реагенти використовували розчини $\mathrm{CaSO}_{4}, \mathrm{Al}_{2}\left(\mathrm{SO}_{4}\right)_{3}$ та нанорозмірний гідроксид алюмінію $\mathrm{Al}(\mathrm{OH})_{3}$, одержаний методом підводного електроіскрового синтезу [6]. Співвідношення кількості та концентрація реагентів описані в табл. 1. Після закінчення процесу екстрагування дослідні зразки поміщали в камеру 6 лабораторної установки і проводили пресування в діапазоні зусиль 0,5 .. 2,5 мПа. При цьому вимірювались зміни геометричних форм зразків - висоти $h$ бурякової тканини при різних показниках стискаючих навантажень. Результати порівнювалися $з$ контрольними зразками бурякової тканини, які підлягали тепловій обробці без використання додаткових реагентів.

Результати досліджень. Відомо, що бурякова тканина має здатність частково відновлювати свою пружність при пї водонасиченні при температурі, яка викликає ii термічну денатурацію [7]. Очевидно, що під час процесу екстрагування вона поглинає вологу і під дією занадто високих температур руйнується. 3 підвищенням температури процесу вище $72{ }^{\circ} \mathrm{C}$ високомолекулярні сполуки із менш стійких тканин переходять в розчин, змінюється геометрія стружки, що приводить до погіршення гідродинамічних умов в дифузійному апараті, проникності сокостружкової суміші і, як наслідок, до зниження чистоти дифузійного соку.

Критерієм визначення ступеня якості бурякової тканини є іiі здатність відновлювати свою форму та пружність при періодичних стискаючих наванта- 
женнях на стружку під час процесів екстрагування й подальшого пресування жому у виробничих умовах. Величиною, яка найточніше може описати якість бурякової тканини, є саме модуль пружності.

Величина модуля пружності залежить від тургору тканини, який, у свою чергу, залежить від спрямованості функціонування клітинних мембран, тому фактори, що негативно впливають на тургор, знижують і модуль пружності. Так, для здорових цукрових буряків модуль пружності коливається в межах від 6 до 14 МПа.

Після кожної серії дослідів проводилося вимірювання зміни геометричної форми зразків, а саме: висоти $h$, циліндричності форми бурякової тканини до та після стискаючих навантажень.

Модуль пружності визначався за законом Гука з відношення:

$$
E=\frac{G}{\varepsilon}
$$

де $G$ - напруження, що викликається в зразку діючою силою; $\varepsilon-$ пружна деформація зразка, викликана напруженням.

$$
G=\frac{P}{F},
$$

де $P$ - сила стискання, прикладена до зразка; $F$ - площа поперечного перерізу зразка.

$$
\varepsilon=\frac{\Delta h}{h}
$$

де $\Delta h-$ зміна розміру зразка після деформації; $h$ - початковий розмір зразка до дії сили.

Результати досліджень, внесені до таблиці, були отримані при статистичній обробці даних серії дослідів [8]. Похибка результатів вимірювань і розрахунків модуля пружності знаходиться в межах 3\%, що свідчить про досить високу точність і достовірність результатів досліджень. До переваг видозміненої та адаптованої методики визначення структурно-механічних характеристик також слід віднести досить невисоку складність проведення вимірювання та розрахунків, що дасть можливість максимально швидко контролювати пружні характеристики бурякової тканини у виробничих умовах.

\begin{tabular}{|c|c|c|c|c|c|}
\hline \multirow[b]{2}{*}{$\begin{array}{c}\text { Спосіб екстрагування } \\
\text { сахарози }\end{array}$} & \multicolumn{2}{|c|}{ Концентрація } & \multicolumn{2}{|c|}{$\begin{array}{c}\text { Модуль пружності зразка } \\
\text { тканини цукрового } \\
\text { буряка, мПа } \\
\end{array}$} & \multirow[b]{2}{*}{$\begin{array}{c}\text { СР віджатого } \\
\text { жому, \% }\end{array}$} \\
\hline & $\begin{array}{c}\text { реагенту } \\
\text { в } \\
\text { розчині, } \\
\%\end{array}$ & \begin{tabular}{|c|} 
реагенту до \\
маси бурякової \\
стружки, \%
\end{tabular} & $\begin{array}{c}\text { до } \\
\text { екстрагува- } \\
\text { ння }\end{array}$ & $\begin{array}{c}\text { після } \\
\text { екстрагу- } \\
\text { вання }\end{array}$ & \\
\hline 1 & 2 & 3 & 4 & 5 & 6 \\
\hline Типовий варіант & - & - & 6,1 & 0,95 & 24,2 \\
\hline
\end{tabular}

Таблиия. Вплив додаткових реагентів на структурно-механічні властивості бурякової тканини 
Продовження табл.

\begin{tabular}{|c|c|c|c|c|c|c|}
\hline \multicolumn{2}{|c|}{1} & 2 & 3 & 4 & 5 & 6 \\
\hline \multirow{2}{*}{$\begin{array}{c}\text { з додавання } \\
\text { хімічних } \\
\text { реагентів }\end{array}$} & $\mathrm{Al}_{2}\left(\mathrm{SO}_{4}\right)_{3}$ & 10,0 & 0,02 & 6,1 & 0,98 & 25,1 \\
\cline { 2 - 7 } & $\mathrm{CaSO}_{4}$ & 10,0 & 0,04 & 6,1 & 1,12 & 26,5 \\
\cline { 2 - 7 } & $\mathrm{Al}(\mathrm{OH})_{3}$ & 0,2 & 0,0015 & 6,1 & 1,31 & 28,1 \\
\hline
\end{tabular}

Висновки. В ході досліджень нами було видозмінено й адаптовано методику визначення структурно-механічних характеристик бурякової тканини. Результати, наведені в табл. 1, підтверджують доцільність використання запропонованого способу визначення модуля пружності зразка тканини цукрового буряка, яка дає змогу досить точно й оперативно контролювати структурномеханічні характеристики сировини при іiі зберіганні та переробці. Це дає можливість оптимізувати процес екстрагування сахарози та пресування жому і таким чином підвищити вихід та якість цільового продукту.

Також встановлено, що всі додаткові реагенти покращують пружні характеристики бурякової тканини, при цьому нанорозмірний гідроксид алюмінію $\mathrm{Al}(\mathrm{OH})_{3}$ показав, що саме його наявність у розчині додаткового реагенту гарантує високі структурно-механічні показники бурякової тканини.

Отже, застосування в процесі екстрагування додаткових реагентів, особливо - нанорозмірного гідроксиду алюмінію $\mathrm{Al}(\mathrm{OH})_{3}$, одержаного методом підводного електроіскрового синтезу [6], забезпечить збереження цілісності структури бурякової тканини в процесах виробничого екстрагування сахарози та пресування жому; зменшить ступінь переходу нецукрів у жомопресову воду в процесі пресування; гарантує високу якість екстрагенту, дифузійного та очищеного соку.

\section{ЛІТЕРАТУРА}

1. Сапронов А.Р. Технология сахарного производства. / А.Р. Сапронов. - 2-е изд., исправл. и доп. - М. : Колос, 1999. - 495 с.

2. Семенихин С.О. Совершенствование технологии извлечения сахарозы из свекловичной стружки: дис. к-та техн. наук: 05.18.05 / Семен Олегович Семенихин. - Краснодар, 2015. - $126 \mathrm{c}$.

3. Bosse E.D. Increase in dry substance of pressed pulp by addition of pressing aids into the pulp press / 29th General Meeting of the American Society of Sugar Beet Technologists Phoenix, Arizona March 2 to 5, 1997. - P. 233-235.

4. Карташов А.К. Реакция свекловичной ткани на различные воздействия / А.К. Карташов, Е.П. Коваль // Сахарная промышленность. - 1985. — № 2.- С. 12-15.

5. Островский Э.В. Оценка механических свойств свекловичной стружки / Э.В. Островский, Д.В. Озеров // Сахарная промышленность. - 1989. - № 2. - С. $17-20$.

6. Патент на корисну модель 38461 UA, МПК (2006) B22F 9/08. Пристрій для отримання колоїдних розчинів ультрадисперсних порошків металів / К.Г. Лопатько, Є.Г. Афтанділянц, А.А. Щерба, С.М. Захарченко, С.А. Яцюк, заявник і патентовласник Національний аграрний університет. — № u200810312; заявл. 12.08.2008; опубл. 12.01.2009, Бюл. № 1, 2009.

7. Беляева Л.И. Исследование упругости ткани сахарной свеклы / Л.И. Беляева, А.И. Чугунов, Д.В. Озеров, П.А. Анатьева // Сахар. - 2007. — № 5. - С. 22-24.

8. Досвід використання нанокомпозиту алюмінію в умовах бурякоцукрового виробництва / В.В. Олішевський, А.І. Українець, К.Г. Лопатько, Н.М. Пушанко, Є.М. Бабко, А.М. Вільченко, В.В. Костюченко, А.І. Маринін, Т.В. Никитюк, С.О. Лапшин // Цукор україни. - 2016. - № 11-12(131-132). - С. 11-17. 
9. Патент 2183015 МКИ 7 G 01 N 3/40 / М.Б. Коновалов, В.В. Спичак, Д.В. Озеров, Э.А. Кирута / Способ определения модуля упругости корнеплодов сахарной свеклы Б.И., - 2002. - № 15 .

\section{МЕТОДИКА ОПРЕДЕЛЕНИЯ СТРУКТУРНО- МЕХАНИЧЕСКИХ СВОЙСТВ СВЕКОЛЬНОЙ ТКАНИ}

Т.В. Никитюк, В.В. Олишевский, Е.Н. Бабко, А.И. Украинец, А.В. Башта Национальный университет пищевых технологий

О.Н. Прокопюк

ООО «Теплоком»

В статье приведена и адаптирована видоизмененная методика для определения структурно-механических характеристик ткани сахарной свеклы в диффрузионно-прессовом способе извлечения сахарозы с использованием дополнительных реагентов. Установлено, что использование дополнительных реагентов способствует улучшению упругих свойств свекольной ткани, при этом наноразмерный гидроксид алюминия $\mathrm{Al}(\mathrm{OH})_{3}$ показал в конечном итоге лучшие показатели.

Ключевые слова: свекловичная ткань, экстрагирование, прессование, наноразмерный гидроксид алюминия, упругость, модуль упругости. 
УДК 641.526.7

\title{
PERSPECTIVE OF ROASTING METHOD OF CULINARY PRODUCTS WITH ELECTRO-CONTACT HEAT TREATMENT
}

\author{
I. Babanov \\ National University of Food Technologies \\ V. Mikhaylov, A. Shevchenko, S. Mikhaylova \\ Kharkiv State University of Food Technology and Trade
}

\author{
Key words: \\ electro-contact heating, \\ roasting, \\ culinary products, \\ heat treatment, \\ electrical current, \\ frequency
}

Article history:

Received 14.01.2018

Received in revised form

19.04.2018

Accepted 03.06.2018

Corresponding author:

igbabanov@ukr.net
ABSTRACT
The article contains a description and advantages of the combined method of frying of culinary products with the use of electro-contact heating $(\mathrm{ECH})$ in a combined mode with the surface and infrared heating. Presented the results of the experimental researches of the method. Substantiated the perceptivity of methods, which is in many advantages, as well as a variety of possible embodiments of the involved processes, depending on the type of product and the desired effect.

The authors propose a method of frying with $\mathrm{ECH}$, which can be used at restaurants of the restaurant and food industry for roasting, baking and baking a wide range of culinary products, semi-finished products which are made on the basis of sopplelike masses or fine-dispersed structures. The method involves a combined treatment: the heating of the inner layers of the product is mainly ECH from the electrode sections and the heating of the surface layers with the formation of crust due to heat from the heating surface and infrared rays. The main advantages of the proposed method of frying with $\mathrm{ECH}$ include the reduction of the length of the process and the reduction of energy consumption due to a combination of different methods of heating, including surface, electrocontact, infrared; ensuring uniform heating of all layers of the product by volume. Under the conditions of setting the voltage of the alternating electric current of rectangular shape (in terms of safety up to $42 \mathrm{~V}$ ), depending on the electrical conductivity of the semifinished products, the possibility of an adjustable supply in the required amount of thermal energy from the $\mathrm{ECH}$, which provides the warming of the inner layers to the cooking temperature during the time required for Creation of a crust on the surface of the product. The rectangular shape of the alternating electric current at given parameters of the amplitude voltage allows to increase the power of the $\mathrm{ECH}$ in contrast to the heating of the sinusoidal current.

DOI: $10.24263 / 2225-2916-2018-23-11$

(C) І.Г. Бабанов, В.М. Михайлов, А.О. Шевченко, С.В. Михайлова, 2018 


\section{ПЕРСПЕКТИВИ СПОСОБУ ЖАРЕННЯ КУЛІНАРНИХ ВИРОБІВ 3 ЕЛЕКТРОКОНТАКТНИМ ТЕПЛОВИМ ВПЛИВОМ}

І.Г. Бабанов, канд. тех. наук

Національний університет харчових технологій

В.М. Михайлов, д-р. тех. наук

А.О. Шевченко, канд. тех. наук

С.В. Михайлова, канд. тех. наук

Харківський державний університет харчування та торгівлі

У статmі описано переваги комбінованого способу жарення кулінарних виробів із застосуванням електроконтактного нагрівання у комбінованому режимі з поверхневим та інфрачервоним нагріванням. Наведено результати експериментальних досліджень способу. Обгрунтовано перспективність способу, що полягає у багатьох перевагах, а також різноманітності можливих варіантів здійснення відповідних процесів залежно від виду продукції та потрібного есректу.

Ключові слова: електроконтактне нагрівання, жарення, кулінарні вироби, теплова обробка, електричний струм, частота.

Постановка проблеми. До важливих проблемних питань галузі харчових виробництв відноситься створення енергозберігаючого обладнання. Так, тривалістю та енергоємністю способів обробки характеризуються теплові апарати, зокрема апарати для жаріння. Слід зауважити, що поряд 3 традиційними способами широко впроваджуються прогресивні методи нагрівання продуктів - в електростатичному полі, струмами промислової частоти, струмами ВЧ та НВЧ, ІЧ-випромінюванням, ультразвуком тощо. Їхня перевага полягає у зниженні енерговитрат, скороченні тривалості процесу, підвищенні якості готових продуктів тощо.

Найбільш простим та ефективним 3 нетрадиційних способів обробки $\epsilon$ електроконтактний тепловий вплив, що здійснюється при безпосередньому контакті електричного струму з продуктом за рахунок теплової енергії, що виділяється за законом Джоуля-Ленца, - електроконтактне нагрівання (ЕКН). На жаль, цей спосіб не знайшов належного застосування в обладнанні підприємств ресторанного господарства, що зумовлює необхідність його дослідженняя.

Аналіз останніх досліджень і публікацій. ЕКН або омічне нагрівання $[1 ; 2]$ характеризується перетворенням електричної енергії в теплову безпосередньо в провідному середовищі. Отримання при цьому внутрішньої енергії за всім об'ємом продукту є важливою перевагою методу [1; 3].

У працях [4; 5] пропонується застосування ЕКН для знищення бактеріальних спор і створення асептичних умов у харчових системах. Стосовно нагрівання електричним струмом різноманітних овочів і фруктів у праці [6] автор ділиться досвідом ЕКН свіжих коренів моркви, що дає змогу покращити колір і структуру тканин продукту. Автори праці [7] здійснювали ЕКН лимонного соку, що надало можливість запропонувати модель, яка може бути корисною для проектування й управління процесом стерилізації. У той же час ЕКН недостатньо досліджений стосовно процесів теплової обробки жарених кулінарних виробів. 
Метою статті $є$ встановлення перспективності способу жарення кулінарних виробів 3 електроконтактним тепловим впливом, дослідження його визначальних параметрів стосовно комбінованої обробки.

Викладення основних результатів дослідження. Запропонований спосіб жарення з ЕКН може використовуватись на підприємствах ресторанного господарства та харчової промисловості для смаження, запікання та випікання широкого асортименту кулінарної продукції, напівфабрикати якої виготовлені на основі фаршеподібних мас або дрібнодисперсних структур. Спосіб передбачає комбіновану обробку: нагрівання внутрішніх шарів виробу переважно ЕКН від електродних секцій та нагрівання поверхневих шарів 3 формуванням скоринки за рахунок теплоти від нагрівальної поверхні та ІЧ-променів. Для реалізації способу електродні секції розміщують перпендикулярно до нагрівальної поверхні, а відстань між електродами регулюється залежно від виду та лінійного розміру напівфабрикатів, які піддаються обробці. Нагрівальну поверхню розігрівають до робочої температури, яка автоматично підтримується на встановленому рівні, а між електродними секціями розміщують напівфабрикати. Одночасно вмикають ІЧ-нагрівачі, попередньо встановивши потрібну потужність, а до електродів подають електричний струм з визначеними параметрами. За рахунок теплоти від нагрівальної поверхні та ІЧ-променів нагріваються переважно поверхневі шари виробу та формується скоринка, а електроконтактним методом здійснюється рівномірне нагрівання внутрішніх шарів виробу за всім об'ємом. Тривалість термообробки зумовлюється видом продукту та його лінійним розміром.

До основних переваг запропонованого способу жарення з ЕКН слід віднести скорочення тривалості технологічних процесів і зниження витрат енергії за рахунок комбінації різних способів нагрівання, зокрема поверхневого, електроконтактного, інфрачервоного; забезпечення рівномірного прогрівання всіх шарів виробу за об’ємом. За умов задавання напруги змінного електричного струму прямокутної форми (з точки зору безпечності до 42 В) залежно від електропровідності напівфабрикатів 3'являється можливість регульованого підведення в необхідній кількості теплової енергії від ЕКН, що забезпечує прогрівання внутрішніх шарів до температури кулінарної готовності протягом часу, необхідного для формування скоринки на поверхні виробу. Прямокутна форма змінного електричного струму при заданих параметрах амплітудної напруги дає змогу підвищити потужність ЕКН на відміну від нагрівання синусоїдальним струмом.

Для підтвердження ефективності способу проведено експериментальні дослідження. Предметом досліджень обрано зразки з натуральної січеної м'ясної маси. Як контрольні використовували зразки продукції, що підлягали двобічному смаженню від нагрівальних поверхонь 3 потужністю нагрівання 0,2 кВт. Як дослідні використовували зразки продукції, що підлягали смаженню комбінованим способом, описаним вище, за таких параметрів комбінованого процесу: потужність поверхневого нагрівання - 0,07 кВт; ЕКН змінним електричним струмом прямокутної форми з частотою 50 Гц і напругою 40 В.

Аналіз отриманих результатів свідчить про більш інтенсивне нагрівання комбінованим способом жарення 3 ЕКН. Так, у контрольного зразка на 1-й хвилині процесу відбувалось незначне підвищення температури, що пов'язано 3 нерівномірним розподілом теплової енергії за об'ємом зразка (температура $є$ 
більшою в поверхневих шарах, ніж у центральних). Далі температура збільшувалась рівномірно за лінійним законом. Під час досліджень способу жарення 3 ЕКН (дослідний зразок) спостерігалось рівномірне прогрівання всіх шарів виробу, процес термообробки скоротився майже в 2 рази. Зразок досяг температури $90^{\circ} \mathrm{C}$ в центрі приблизно через 180 с. При цьому на поверхні виробу сформувалась скоринка, притаманна жареним виробам.

Перспективність запропонованого способу обгрунтовується багатьма перевагами, а також різноманітністю можливих варіантів здійснення відповідних процесів залежно від виду продукції та потрібного ефекту. У зв'язку з цим набуває актуальності завдання, пов'язане з розробкою високоефективного комбінованого способу для різних за рецептурою кулінарних виробів і відповідних теплових режимів. Для ії вирішення авторами проводяться подальші дослідження з вивченню зміни електрофізичних властивостей різноманітної харчової сировини як складових компонентів багатокомпонентних фаршевих виробів, та їх впливу на тривалість процесу, а також визначення раціональних параметрів проведення процесу ЕКН у комбінації з іншими способами. Основним практичним результатом роботи має бути створення комбінованого енергозберігаючого способу й апарату, що дає можливість знизити трудомісткість та інтенсифікувати теплову обробку, а також отримати високоякісний екологічно чистий продукт.

Висновки. Запропоновано спосіб жарення з ЕКН у комбінованому режимі 3 поверхневим та ІЧ-нагріванням. Досліджено зміну температури для зразків оброблених шляхом традиційного смаження та комбінованим способом. Більш інтенсивне нагрівання спостерігалось в останнього, що підтверджує його ефективність. Перспективність способу обгрунтовується його перевагами та різноманітністю можливих варіантів здійснення відповідних процесів у залежності від виду продукції та потрібного ефекту.

\section{ЛITEРАТУРА}

1. Нові технічні рішення в проектуванні обладнання для теплової обробки харчової сировини : монографія в 3 ч. Ч. 2. Використання електроконтактного нагрівання в процесах жарення кулінарної продукції / О.І. Черевко [та ін.]; за заг. ред. О.І. Черевка, В.М. Михайлова. - Х. : ХДУХТ, 2012. - 151 с.

2. Ohmic heating [Електронний pecypc]: Britannica Online Encyclopedia. - Режим доступу : http://www.britannica.com/EBchecked/topic/426067/ohmic-heating.

3. Усовершенствование производства колбасных изделий с применением электрофизических методов обработки / І.Г. Бабанов, О.І. Бабанова,В.М. Михайлов, А.О. Шевченко // Scientific Works of University of Food Technologies. — Plovdiv, 2015. - V. LXII. P. 763-766.

4. Ohmic heating as an alternative food processing technology: a report / D.R. Anderson. Manhattan: Kansas State University, 2008. - 45 p.

5. Effects of ohmic heating on microbial counts and denaturation of proteins in milk / H. Sun, S [at al.] // Food Science and Technology Research. - 2008. - Val 14(2). P. $117-123$.

6. Effect of ohmic heating on color, rehydration and textural characteristics of fresh carrot cubes: a thesis / S. D. Bhale // Graduate faculty of the Louisiana State University and Agricultural and Mechanical College. - Mahatma, 1997. - $56 \mathrm{p}$.

7. Ohmic processing: temperature dependent electrical conductivities of lemon juice / H. Darvishi [at al.] // Modern applied science, 2011. — V. 5, \# 1. — P. 209-216. 


\section{ПЕРСПЕКТИВЫ СПОСОБА ЖАРЕНИЯ КУЛИНАРНЫХ ИЗДЕЛИЙ С ЭЛЕКТРОКОНТАКТНЫМ ТЕПЛОВЫМ ВОЗДЕЙСТВИЕМ}

\section{И.Г. Бабанов}

Национальный университет пищевых технологий

В.М. Михайлов, А.А. Шевченко, С.В. Прасол

Харьковский государственный университет питания и торговли

В статье описаны преимущества комбинированного способа жарения кулинарных изделий с использованием электроконтактного нагрева в комбинированном режиме с поверхностным и инфрракрасным нагревом. Приведены результаты экспериментальных исследований способа. Обоснована перспективность способа, которая заключается во многих преимуществах, а также в разнообразии возможных вариантов осуществления соответствующих процессов в зависимости от вида продукции и нужного эффректа.

Ключевые слова: электроконтактный нагрев, жарка, кулинарные изделия, тепловая обработка, электрический ток, частота. 
УДК 621.929:664

\title{
SIMULATION OF BULK MATERIALS MIXING PROCESS IN GRAVITATIONAL MIXER
}

\section{Dudarev}

Lutsk National Technical University

\begin{tabular}{|c|c|}
\hline Key words: & ABSTRACT \\
\hline $\begin{array}{l}\text { simulation, } \\
\text { mixing process, } \\
\text { bulk material, } \\
\text { gravitational mixer }\end{array}$ & $\begin{array}{l}\text { The bulk materials mixing process is extremely difficult for a } \\
\text { mathematical description. This is due to the fact that the process is } \\
\text { influenced by a number of factors: physical and mechanical proper- } \\
\text { ties of bulk materials; number of materials that mix at the same }\end{array}$ \\
\hline $\begin{array}{l}\quad \text { Article history: } \\
\text { Received } 11.04 .2018 \\
\text { Received in revised form } \\
\text { 01.05.2018 } \\
\text { Accepted } 29.05 .2018\end{array}$ & $\begin{array}{l}\text { time; ratio between components in the mixer; design features of the } \\
\text { mixer; mixer parameters; mixing method. As a rule, in the food } \\
\text { production process it is necessary to mix several bulk materials. } \\
\text { Known researches of the mixing process indicate that most of the } \\
\text { proposed mathematical models describe the mixing of the two }\end{array}$ \\
\hline $\begin{array}{l}\text { Corresponding author: } \\
\text { i_dudarev@ukr.net }\end{array}$ & $\begin{array}{l}\text { components. Mathematical models of the mixing process are divi- } \\
\text { ded into deterministic and stochastic. Mathematical equations of } \\
\text { the Markov's chains theory are used in most stochastic models of } \\
\text { the mixing process. These models are most widely used to describe } \\
\text { the mixing process in the gravitational mixers. The research of } \\
\text { component flows in a gravitational mixer and design parameters of } \\
\text { the mixer are necessary for the creation of such mathematical } \\
\text { models of the mixing process. Gravitational mixers have an advan- } \\
\text { tage over other designs of mixers because they are energy efficient } \\
\text { and do not damage bulk materials. The new design of the gravita- } \\
\text { tional mixer of bulk materials is proposed in the article. The process } \\
\text { of bulk materials mixing in the mixer takes place without energy } \\
\text { costs. The design parameters of the mixer were justified by modeling } \\
\text { the process of four bulk materials mixing. These design parameters } \\
\text { will ensure a high quality of bulk materials mix. The Markov's } \\
\text { random process equations were used to model the mixing process. } \\
\text { Also an analysis of possible cases of moving bulk materials by the } \\
\text { working surfaces of the gravitational mixer was made in the article. } \\
\text { This analysis allowed the construction of graphs of the possible } \\
\text { states of the particles of the four components during their move- } \\
\text { ment by the sections of the gravitational mixer. The mathematical } \\
\text { model of bulk materials mixing process can be used for other } \\
\text { designs of gravitational mixers or other quantity of bulk materials. }\end{array}$ \\
\hline
\end{tabular}

\section{МОДЕЛЮВАННЯ ПРОЦЕСУ ЗМІШУВАННЯ СИПКИХ МАТЕРІАЛІВ У ГРАВІТАЦІЙНОМУ ЗМІШУВАЧІ}

\author{
І.М. Дударєв, д-р техн. наук \\ Луцький національний технічний університет
}

У статті запропонована конструкція гравітаційного змішувача сипких матеріалів, в якому процес змішування сипких матеріалів відбувається без енерго-

(C) I.M. Дударєв, 2018 
витрат. Здійснене моделювання процесу змішування чотирьох сипких матеріалів у запропонованій конструкції змішувача із використанням математичного апарата, що розроблений для марковського випадкового прочесу, дало змогу обгрунтувати конструктивні параметри змішувача, за яких буде забезпечено високу якість суміші. Моделювання процесу змішування проведено на основі аналізу можливих випадків переміщення частинок сипких матеріалів робочими поверхнями гравітаційного змішувача, що надало можливість побудувати графи можливих станів частинок чотирьох компонентів під час їх руху секціями змішувача. Розроблена математичне модель процесу змішування сипких матеріалів може бути застосована і для інших конструкцій гравітаційних змішувачів або іншої кількості сипких матеріалів.

Ключові слова: моделювання, процес змішування, сипкий матеріал, гравітаційний змішувач.

Постановка проблеми. У харчовій промисловості широко застосовується змішування сипких матеріалів, у результаті якого необхідно одержати суміш iз рівномірним розподілом у відповідній пропорції компонентів за об'ємом суміші. При цьому також необхідно не допустити пошкодження компонентів і забезпечити якомога менші енерговитрати на процес. Серед відомих конструкцій змішувачів сипких матеріалів низку переваг мають гравітаційні змішувачі без активних робочих органів (барабанні, дискові, спіральні, лоткові, решітчасті), оскільки не зумовлюють пошкодження матеріалів і прості в обслуговуванні. Окремі конструкції гравітаційних змішувачів (лоткові, решітчасті) не потребують енерговитрат на здійснення процесу змішування. Обгрунтування параметрів змішувачів, за яких би досягалася необхідна якість готової суміші, здійснюють шляхом математичного моделювання процесу змішування у них. Процес змішування сипких матеріалів надзвичайно складний для математичного опису. Це зумовлено тим, що на його перебіг впливає низка факторів: фізико-механічні властивості сипких матеріалів; кількість матеріалів, що одночасно змішуються; співвідношення між компонентами; конструктивні особливості змішувача; параметри змішувача; спосіб змішування. Найбільш впливовими факторами на процес змішування $€$ властивості матеріалів та конструктивні особливості змішувача, що визначають тривалість процесу та його енергоємність, тобто впливають на кількісні параметри процесу. Тому актуальними є дослідження, що спрямовані на розробку нових та удосконалення існуючих підходів до моделювання процесу змішування сипких матеріалів, які б враховували особливості конструкції та роботи змішувача, а також давали змогу змоделювати процес одержання багатокомпонентної суміші.

Як правило, в процесі виробництва продуктів харчування необхідно змішувати кілька сипких матеріалів (компонентів). Відомі дослідження процесу змішування вказують на те, що більшість запропонованих математичних моделей описують змішування двох компонентів [1-5]. У разі, якщо необхідно змоделювати змішування більшої кількості сипких матеріалів, тоді один 3 матеріалів приймають за один компонент, а решту матеріалів - за другий компонент, або ж здійснюють поетапне змішування матеріалів. Математичний опис поетапного змішування зводиться до багаторазового застосування двокомпонентної моделі змішування. Для моделювання процесу змішування сипких матеріалів використовують різні підходи: емпіричний, аналізу структури потоків матеріалів, механіки суцільних середовищ, статистичний тощо. Грунтовний аналіз та класифіка- 
цію моделей процесу змішування сипких матеріалів представлено у науковій праці [1], де моделі поділяють на дві групи: детерміновані та стохастичні. До стохастичних, зокрема, відносяться моделі, що засновані на математичному апараті теорії ланцюгів Маркова. Ці моделі найбільш широко використовуються для опису процесу змішування у гравітаційних змішувачах, оскільки математичний апарат теорії ланцюгів Маркова надає можливість визначити ймовірності перебування компонентів суміші в їі об'ємі та описати переміщення компонентів під час змішування. Побудова таких моделей потребує детального вивчення потоків компонентів у змішувачі з урахуванням його конструкції.

Мета дослідження: розробити математичну модель процесу змішування чотирьох сипких матеріалів у гравітаційному змішувачі, що заснована на математичному апараті марковського випадкового процесу.

Матеріали і методи. Для математичного опису процесу змішування сипких матеріалів у гравітаційному змішувачі застосовувався математичний апарат, що розроблений для марковського випадкового процесу з дискретними етапами $\mathrm{i}$ часом. Моделювання здійснювалося на основі припущень, які обгрунтовані в попередніх дослідженнях [6], зокрема, про те, що під час сходження частинки матеріалу зі спрямовувача об'єднувача можливі три випадки іï руху (рис. 1). Оскільки для сипких матеріалів рівноймовірні усі три випадки, відповідно, ймовірність того, що частинка матеріалу, яка сходить 3 лівого спрямовувача об'єднувача потоків, опиниться на лівому спрямовувачі розділювача потоку, тобто не перетне площину П (рис. 1), складає $P_{\text {лів. }}=2 / 3$, а ймовірність того, що частинка матеріалу опиниться на правому спрямовувачі розділювача потоків, тобто перетне площину П, складає $P_{\text {пр. }}=1 / 3$.
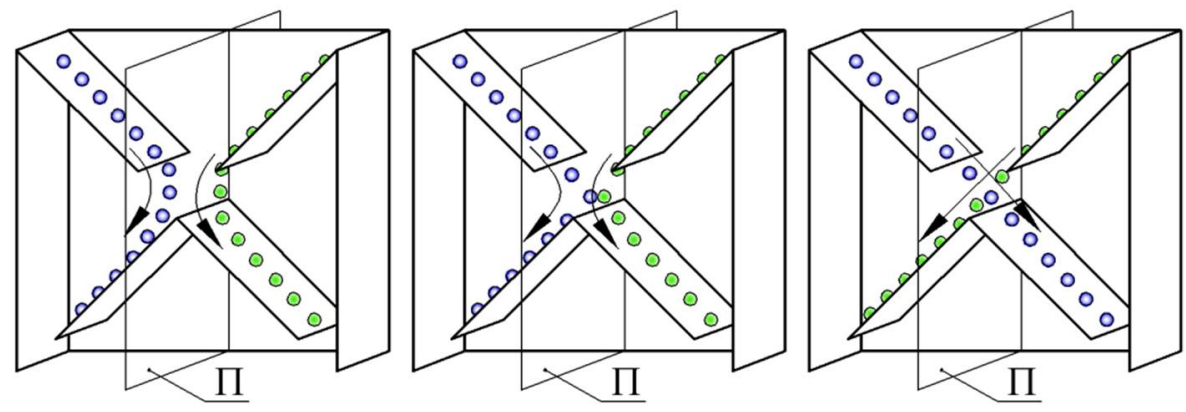

Рис. 1. Схеми можливих випадків переміщення компонентів секцією

Результати досліджень. Пропонується конструкція гравітаційного змішувача сипких матеріалів (рис. 2), що містить вертикальну колону, яку утворено закріпленими одна над одною однаковими секціями, які повернуті одна відносно одної на кут $90^{\circ}$ у горизонтальній площині. Секція утворена корпусом, всередині якого закріплені дві вертикальні перегородки. До кожної перегородки прикріплено об'єднувач та розділювач, що призначені відповідно для об'єднування потоків компонентів і розділення потоку компонентів. Кожен об'єднувач i розділювач утворений двома спрямовувачами. Над колоною передбачено чотири завантажувачі, а під нею - ємкість для суміші. Під час переміщення потоків компонентів і сумішей відбувається їх багаторазове об'єднування та розділення, що зумовлює змішування. 


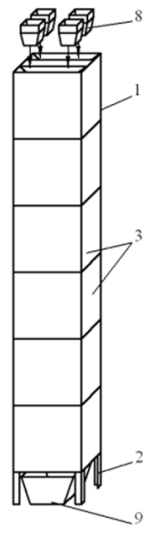

a

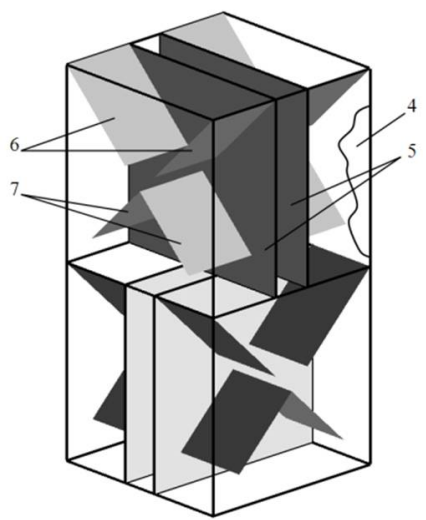

6

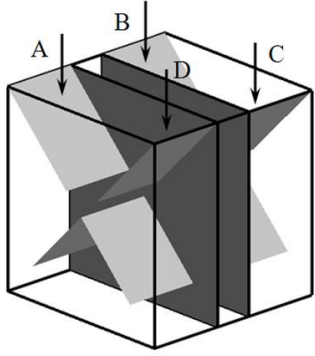

B

Рис. 2. Гравітаційний змішувач сипких матеріалів: а - загальний вигляд; б - схема внутрішньої будови двох секцій колони; в - схема завантаження компонентів $A, D, B$ та $C$ у верхню секцію (1 - колона; 2 - опори; 3 - секції; 4 - корпус; 5 - перегородки; 6 спрямовувачі об'єднувача; 7 - спрямовувачі розділювача; 8 - завантажувачі; 9 - ємкість)

Дослідимо рух потоків компонентів $A, D, B$ та $C$ і їх сумішей у гравітаційному змішувачі із врахуванням його конструктивних особливостей. Для цього у кожному з чотирьох початкових потоків компонентів, які подаються завантажувачами на спрямовувачі об’єднувачів верхньої секції, виокремимо по одній частинці матеріалу та визначимо ймовірність перебування цих частинок компонентів на спрямовувачах розділювачів кожної секції. Знаходження частинок компонентів на спрямовувачах розділювачів називатимемо їх станами $S_{i}$ (де $S_{i}-i$-й стан частинки компонента). Кожному спрямовувачу розділювачів усіх секцій та спрямовувачам об'єднувачів верхньої секції відповідає певний стан частинок матеріалів. Усі стани частинок компонентів пронумеруємо так, як показано на рис. 3. Нехай частинка компонента $A$ у початковий момент перебуває у стані $S_{1}$ на спрямовувачі об'єднувача верхньої секції, а частинки компонентів $B, C$ та $D$ відповідно у станах $S_{2}, S_{3}$ та $S_{4}$ на спрямовувачах об'єднувачів верхньої секції. Подальші розрахунки здійснюватимемо для восьмисекційної колони, тоді кількість можливих станів для частинок усіх чотирьох компонентів складатиме $n=36$. Частинки чотирьох компонентів, рухаючись вниз секціями змішувача, можуть перебувати в $n$ станах $S_{1}, S_{2}, \ldots, S_{n}$. Можливі переходи частинок компонентів зі стану в стан на графах станів позначені стрілками (рис. 3). Відповідно до прийнятих припущень [6] відомими $€$ ймовірності можливих переходів частинок компонентів зі стану в стан, які на рис. 3 зазначені поряд зі стрілками. Позначимо через $P_{i j}$ ймовірність переходу частинки зі стану $S_{i}$ в стан $S_{j}$. Якщо окремі переходи неможливі, тоді їх ймовірності рівні нулю. Ймовірність станів частинки компонента $p_{1}(k), p_{2}(k), \ldots$, $p_{n}(k)$ після довільного $k$-го етапу [6]:

$$
p_{i}(k)=\sum_{j=1}^{n} p_{j}(k-1) \cdot P_{j i},(i=\overline{1, n}),
$$

де $P_{i j}$ - ймовірність переходу частинки компонента зі стану $S_{i}$ в стан $S_{j}$. 
Для прикладу за формулою (1) визначимо ймовірності перебування частинки компонента $A$ на спрямовувачах розділювачів (в станах $S_{i}$ ) під час іiї руху верхніми чотирма секціями вертикальної колони (рис. $3 \mathrm{a}$ ):

1) у стані $S_{1}: p_{1}(0)=1$

2) у стані $S_{5}: p_{5}(1)=p_{1}(0) \cdot P_{15}=0,666$;

3) у стані $S_{8}: p_{8}(1)=p_{1}(0) \cdot P_{18}=0,333$;

4) у стані $S_{9}: p_{9}(2)=p_{5}(1) \cdot P_{59}=0,444$;

5) у стані $S_{10}: p_{10}(2)=p_{5}(1) \cdot P_{510}=0,222$;

6) у стані $S_{11}: p_{11}(2)=p_{8}(1) \cdot P_{811}=0,111$;

7) у стані $S_{12}: p_{12}(2)=p_{8}(1) \cdot P_{812}=0,222$;

8) у стані $S_{13}: p_{13}(3)=p_{9}(2) \cdot P_{913}+p_{12}(2) \cdot P_{1213}=0,370$;

9) у стані $S_{14}: p_{14}(3)=p_{10}(2) \cdot P_{1014}+p_{11}(2) \cdot P_{114}=0,185$;

10) у стані $S_{15}: p_{15}(3)=p_{10}(2) \cdot P_{1015}+p_{11}(2) \cdot P_{1115}=0,148$;

11) у стані $S_{16}: p_{16}(3)=p_{9}(2) \cdot P_{916}+p_{12}(2) \cdot P_{1216}=0,296$;

12) у стані $S_{17}: p_{17}(4)=p_{13}(3) \cdot P_{1317}+p_{14}(3) \cdot P_{1417}=0,309$;

13) у стані $S_{18}: p_{18}(4)=p_{13}(3) \cdot P_{1318}+p_{14}(3) \cdot P_{1418}=0,247$;

14) у стані $S_{19}: p_{19}(4)=p_{15}(3) \cdot P_{1519}+p_{16}(3) \cdot P_{1619}=0,197$;

15) у стані $S_{20}: p_{20}(4)=p_{15}(3) \cdot P_{1520}+p_{16}(3) \cdot P_{1620}=0,247$.

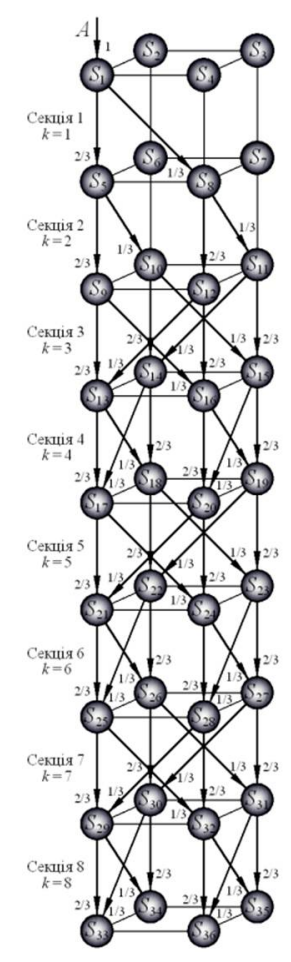

a

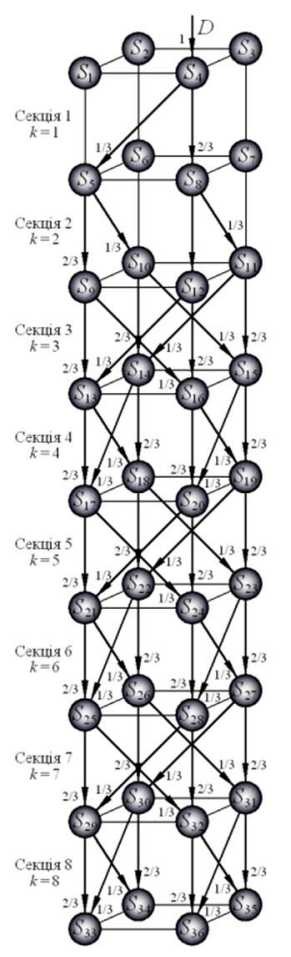

6

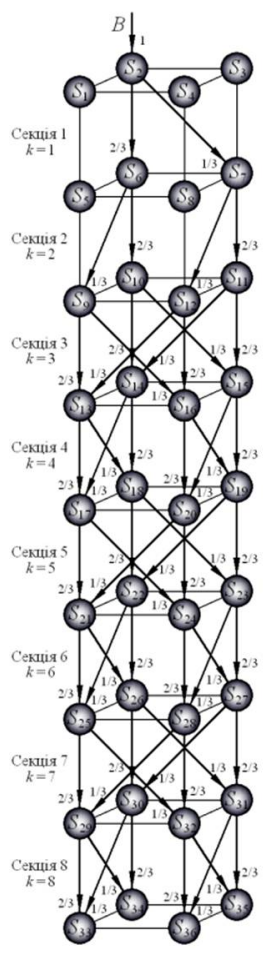

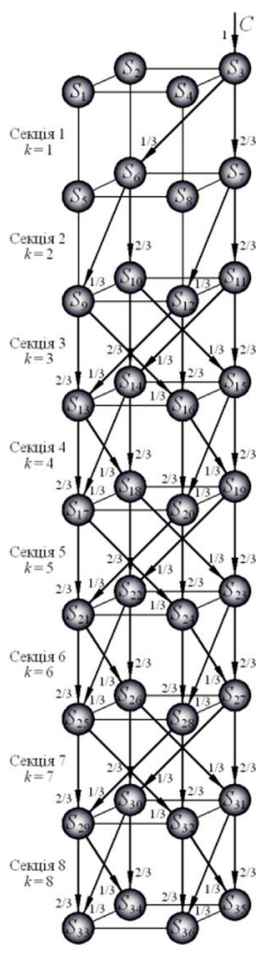

B

Рис. 3. Графи можливих станів частинок чотирьох компонентів:

a - компонент $A$; б- компонент $D$; в - компонент $B$; г- компонент $C$ 
Розрахунки для решти секцій здійснюються аналогічно. Ймовірності перебування частинок компонентів $B, C$ та $D$ на спрямовувачах розділювачів під час їх руху секціями визначаються у той самий спосіб, що і для частинки компонента $A$ (рис. 3,6, в, г). Результати розрахунку ймовірностей перебування частинок у станах $S_{i}$ представлені на рис. 4 .

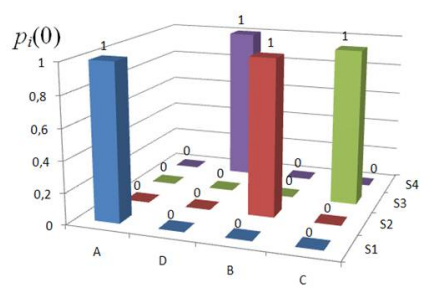

Завантаження

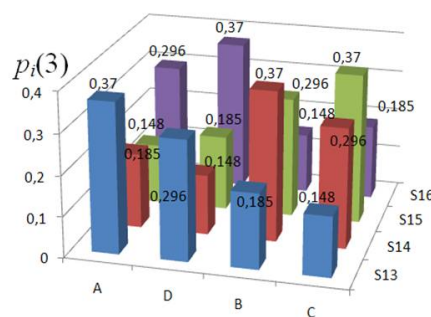

Секція 3

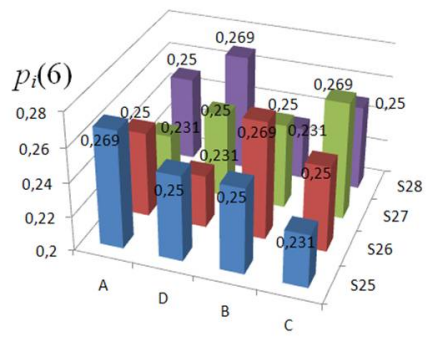

Секція 6

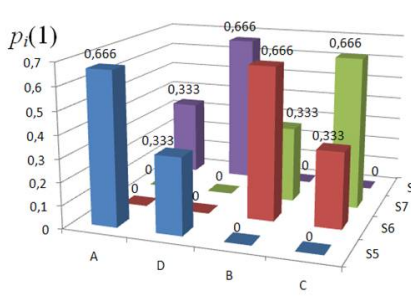

Секція 1

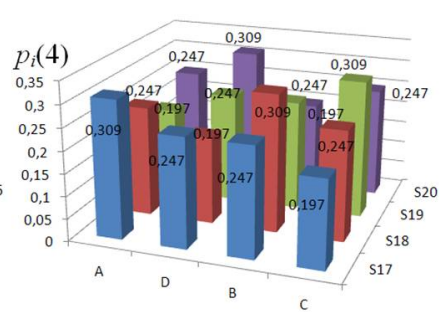

Секція 4

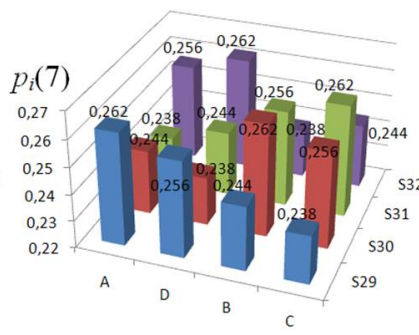

Секція 7

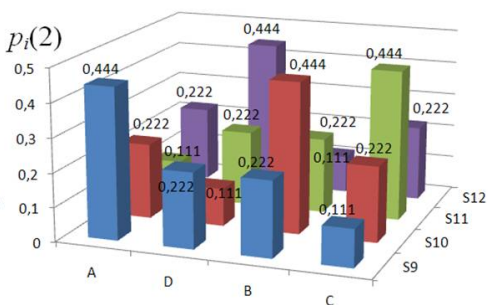

Секція 2

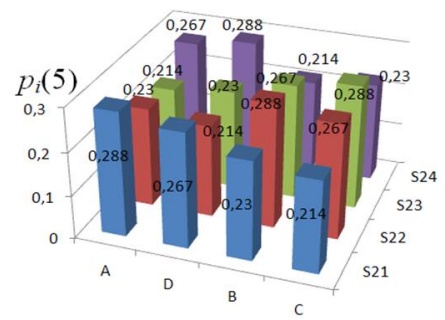

Секція 5

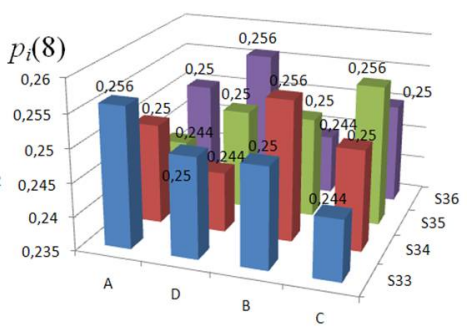

Секція 8

Рис. 4. Імовірності перебування частинок $A, D, B$ та $C$ у станах $S_{i}$

Висновки. Рівномірний розподіл усіх компонентів у чотирьох потоках суміші, що виходять із нижньої секції змішувача, матиме місце у випадку, якщо для кожного компонента у кожному потоці суміші буде забезпечена його кількість, що складає 25\% від кількості цього компонента, яка завантажується у верхню секцію змішувача. Такий результат можна досягнути, якщо ймовірність перебування частинок кожного із чотирьох компонентів на чотирьох спрямовувачах двох розділювачів нижньої секції змішувача становитиме 0,25 . Результати моделювання процесу змішування чотирьох сипких матеріалів у гравітаційному змішувачі із використанням математичного апарата, що розроблений для марковського випадкового процесу, свідчать про те, що в чотирьох потоках суміші компонентів, які сходять зі спрямовувачів розділювачів нижньої секції (секція 8) змішувача, ймовірність перебування частинок компонентів $A, D, B$ та $C$ знаходиться в межах $0,244 \ldots 0,256$. У разі такого розподілу компонентів буде 
одержана висока якість суміші. Отже, для досягнення такої якості суміші цілком достатньо восьми секцій у складі вертикальної колони, оскільки подальше збільшення їх кількості не призведе до суттєвого покращення якості суміші, а зумовить лише збільшення металомісткості конструкції змішувача і зростання тривалості процесу. Розроблена математична модель процесу змішування сипких матеріалів може бути застосована і для інших конструкцій гравітаційних змішувачів або іншої кількості сипких матеріалів.

\section{ЛІТЕРАТУРА}

1. Бакин М.Н. Современные методы математического описания процесса смешивания сыпучих материалов / М.Н. Бакин, А.Б. Капранова, И.И. Верлока // Фундаментальные исследования. — 2014. — № 5(5). - С. 923-927.

2. Волков М.B. Математическая модель процесса смешивания сыпучих материалов в новом устройстве гравитационно-пересыпного действия / М.В. Волков, Л.В. Королев, М.Ю. Таршис // Фундаментальные исследования. — 2014. — № 9(5). — С. 960 — 964.

3. Смолин Д.О. Математическая модель смешивания сыпучих материалов в лопастных смесителях // Д.О. Смолин, О.В. Демин, В.Ф. Першин // Современные проблемы науки и образования. - 2013. - № 2 [Електронний ресурс]. — Режим доступу : http://www.science-education.ru/ru/article/view?id $=8703$

4. Балагуров И.А. Моделирование кинетики смешивания разнородных сыпучих материалов / И.А. Балагуров, В.Е. Мизонов, Н. Berthiaux, С. Gatumel // Вестник ИГЭУ. 2014. — Вип. 6 [Електронний ресурс]. - Режим доступу : http://vestnik.ispu.ru/ru/node/322\#

5. Рябов Р.М. Аналіз теоретичних досліджень процесу змішування / Р.М. Рябов, Д.О. Мілько // Вісник Сумського національного аграрного університету. Серія «Механізація та автоматизація виробничих процесів». — 2016. - Вип. 10/2(30). - С. 102-106.

6. Дударєв I.M. Розрахунок машин зі спіральними робочими поверхнями: монографія / І.М. Дударєв. - Луцьк : Інформ.-вид. відділ Луцького НТУ, 2017. — 228 с.

\section{МОДЕЛИРОВАНИЕ ПРОЦЕССА СМЕШИВАНИЯ СЫПУЧИХ МАТЕРИАЛОВ В ГРАВИТАЦИОННОМ СМЕСИТЕЛЕ}

И.Н. Дударев

Луцкий национальный технический университет

В статье предложена конструкция гравитационного смесителя сыпучих материалов, в котором процесс смешивания сыпучих материалов происходит без энергетических затрат. Моделирование процесса смешивания четырех сыпучих материалов в предложенной конструкции смесителя с использованием математического аппарата, который разработан для марковского случайного процесса, позволило обосновать конструктивные параметры смесителя, при которых будет обеспечено высокое качество смеси. Моделирование процесса смешивания произведено на основе анализа возможных случаев перемещения сыпучих материалов рабочими поверхностями гравитационного смесителя, что позволило построить графы возможных состояний частиц четырех компонентов во время их движения секциями смесителя. Разработанная математическая модель процесса смешивания сыпучих материалов может быть использована и для других конструкций гравитационных смесителей или другого количества сыпучих материалов.

Ключевые слова: моделирование, процесс смешивания, сыпучий материал, гравитационный смеситель. 


\title{
УДК 628.166-926.214
}

\section{DEVELOPMENT OF A SCHEME FOR PROCESSING OF NANOFILTRATION PERMEATE}

\author{
V. Zakharov, Yu. Zmievskii, V. Myronchuk \\ National University of Food Technologies \\ Yu. Dzyazko \\ V.I. Vernadskii Institute of General and Inorganic Chemistry of the NAS of Ukraine
}

\begin{tabular}{l}
\hline \multicolumn{1}{c}{ Key words: } \\
ozone, \\
ozonation station, \\
milk whey, \\
nanofiltration permeate, \\
organic compounds, \\
dry matter, \\
demineralization
\end{tabular}

Article history:

Received 29.04.2018

Received in revised form 09.05.2018

Accepted 08.06.2018

Corresponding author: saharoff.911@gmail.com
In the work was proposed and scientifically substantiated the method of efficient processing of nanofiltration permeate of milk whey, using ozonation and electrodialysis processes. In materials and methods is given the scheme and principle of operation of the device for experimental studies, which included an oxygen concentrator, an ozonizer, an ozonizing apparatus, a foam trapper, two glasses of Drexel and rotameter. The iodometric ozone determination method used in the studies is briefly described. According to the results of the work, the use of ozone in the contact apparatus is determined, which is $25 \%$. In the course of new experiments, the total transmitted dose zone (TOD) was also defined, which provides removal of $96 \%$ organic compounds on the sorption filter. This parameter should be in the range of $20 \ldots 28 \mathrm{mg} / \mathrm{dm}^{3}$. The dependence of the residual ozone $\mathrm{C}\left(\mathrm{O}_{3}\right)$ on the total transmitted dose of ozone (TOD) has been obtained. It was established that in order to achieve the aftereffect of making the microflora in the ozone-treated nanofiltration permeate impossible, the minimum amount of transmitted ozone (TOD) should not be less than $2,5 \mathrm{mg} / \mathrm{dm}^{3}$. The mechanism of oxidation of organic compounds by ozone and products of its decomposition is described. They are hydroxyl radicals $\mathrm{OH}$ and oxygen $\mathrm{O}_{2}$. According to the results of the work, was proposed a low-waste scheme for the processing of nanofiltration permeate of milk whey. The essence of the scheme is the processing of nanofiltration permeate at an ozonation station, for the removal of organic compounds. Further separation on reverse osmosis and obtaining a solution of mineral salts from the concentrate for mineralization and remineralization. The filtrate after the reverse osmosis station and the diluate after the electrodialysis station is offered to further process the residual ozone and be used for washing the equipment.

DOI: $10.24263 / 2225-2916-2018-23-13$

(C) В.В. Захаров, Ю.Г.Змієвський, В.Г. Мирончук, Ю.С. Дзязько, 2018 


\title{
РОЗРОБЛЕННЯ СХЕМИ ПЕРЕРОБКИ НАНОФІЛЬТРАЦІЙНОГО ПЕРМЕАТУ МОЛОЧНОÏ СИРОВАТКИ
}

\author{
B.В. Захаров \\ Ю.Г. Змієвський, канд. техн. наук \\ В.Г. Мирончук, д-р техн. наук \\ Національний університет харчових технологій \\ Ю.С. Дзязько, канд. хім. наук \\ Інститут загальної та неорганічної хімії ім. В.І. Вернадського НАН України
}

У статті запропоновано і науково обгрунтовано спосіб ефрективної переробки нанофрільтраційного пермеату молочної сироватки шляхом використання процесів озонування й електродіалізу. Визначено коефіцієнт використання озону в контактному апараті, який становить 25\%. Отримано залежність залишкового озону $\mathrm{C}\left(\mathrm{O}_{3}\right)$ від загальної переданої дози озону (TOD). Встановлено, що для досягнення постефекту унеможливлення розвитку мікрофрлори в обробленому озоном нанофільтраційному пермеаті мінімальна кількість TOD не повинна бути меншою 2,5 мг/дм ${ }^{3}$. За результатами дослідження запропоновано маловідходну схему переробки нанофрільтраційного пермеату молочної сироватки.

Ключові слова: озон, станція озонування, молочна сироватка, нанофрільтраційний пермеат, органічні сполуки, сухі речовини, демінералізація.

Постановка проблеми. Одна 3 найпотужніших галузей харчової промисловості України - молочна. Вона виробляє найрізноманітнішу продукцію, серед якої щомісяця, за даними Державної служби статистики України, виробляється в середньому 20 тис. тонн сирів. Під час їх виробництва утворюється велика кількість молочної сироватки. Залежно від виду продукту вихід сироватки стосовно до переробленого молока може складати: сир кисломолочний - $80 \pm 3 \%$; сири натуральні - $78 \pm 3 \%$; казеїн - 75 $\pm 3 \%$; сири знежирені, низької жирності та бринза - $65 \pm 3 \%$ [1-5].

Ще у минулому столітті питання використання молочної сироватки було великою проблемою для галузі. Однак поява нового мембранного процесу нанофільтрації (НФ) дала змогу частково вирішити ці завдання. НФ дає можливість сконцентрувати молочну сироватку до вмісту сухих речовин $20 \pm 3 \%$ при одночасному іiі знесоленні на $25 . .30 \%$. Отриманий у такий спосіб концентрат краще зневоднюється під час розпилювального сушіння та має поліпшені органолептичні властивості. Проте утворений НФ пермеат потребує подальшої переробки за рахунок високого значення хімічного споживання кисню (ХСК) та вмісту одновалентних іонів, що можуть у подальшому використовуватись у технологіях ремінералізації та домінералізації питної води. Це потребувало відповідних наукових досліджень, внаслідок відсутності ефективних технологій перероблення НФ пермеату.

Мета статті: розроблення схеми максимально повного використання нанофільтраційного пермеату молочної сироватки.

Матеріали і методи. Установка для експериментальних досліджень наведена на рис. 1. Компресором, який вмонтований у корпус концентратору кисню 1 , всмоктується повітря з навколишнього середовища. Спочатку повітря проходить грубий фільтр для відділення крупних завислих домішок, а потім на фільтросушувач, для зменшення вмісту вологи. Ці операції необхідні для збереження стабільної роботи концентратора кисню та озонатора. Далі відбувається концен- 
трування кисню у повітрі до 90...95\%. Отриманий кисневий концентрат надходить в озонатор 2. За рахунок електричного розряду у розрядній камері озонатору виробляється озон. Його вміст у газовій суміші складав близько $4 . .6 \%$. Такий показник досягнуто саме завдяки застосуванню концентратора кисню. На цьому етапі отримується вже робоча озоно-газова суміш, яка в подальшому і використовується для здійснення процесу озонування.

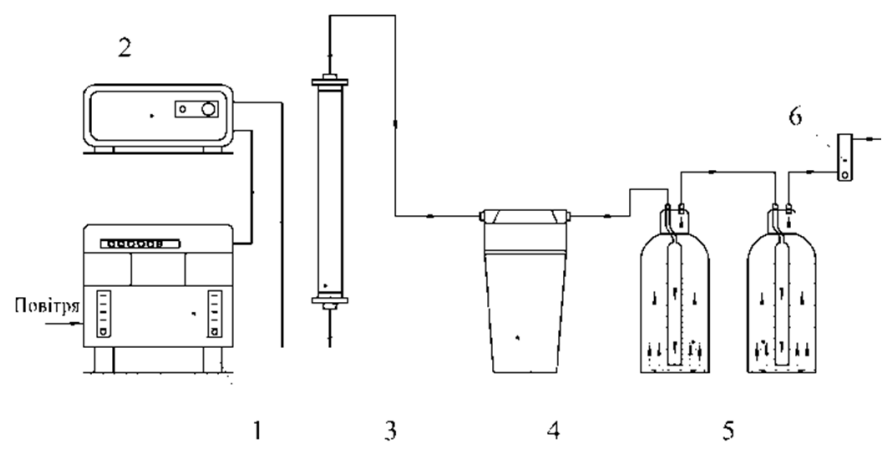

Рис. 1. Схема лабораторної установки для озонування

Процес озонування відбувався у контактній ємності 3. Це циліндричний реактор, висота корпусу якого 0,34 м, внутрішній діаметр 0,032 м. Загальний об’єм контактної ємності 0,5 дм $^{3}$, робочий об'єм 0,4 дм³. Через з'єднувальну трубку озоногазова суміш надходила до нижньої частини контактної ємності, де встановлена сітка-розподільник, і потрапляла у робочий об'єм апарата. Проходячи через шар оброблюваного розчину, залишковий озон виходив з верхньої частини апарата, проходив через вловлювач піни 4 та дві склянки Дрекселя 5 з розчином калій йодиду (KI). Озон вступає у реакцію з калій йодидом, утворюючи еквівалентну кількість йоду. Реакцію, яка відбувається, можна представити формулою (1):

$$
2 \mathrm{KI}+\mathrm{O}_{3}+\mathrm{H}_{2} \mathrm{O} \rightarrow 2 \mathrm{KOH}+\mathrm{O}_{2}+\mathrm{I}_{2} .
$$

У подальшому кількість озону, яка надійшла до склянок Дрекселя, визначалась титруванням. Йод відтитровувався тіосульфатом натрія. Хімічна формула реакції має такий вигляд (2):

$$
\mathrm{I}_{2}+\mathrm{Na}_{2} \mathrm{~S}_{2} \mathrm{O}_{3} \rightarrow 2 \mathrm{NaI}+\mathrm{Na}_{2} \mathrm{~S}_{4} \mathrm{O}_{6}
$$

Безпосередню кількість озону визначали за формулою (3):

$$
\left(\mathrm{O}_{3}\right)=\frac{(C V) \mathrm{Na}_{2} \mathrm{~S}_{2} \mathrm{O}_{3} \cdot M\left(\mathrm{O}_{3}\right)_{\text {екв. }}}{1000} \cdot \frac{V_{\mathrm{K}}}{V_{\Pi}},
$$

де $(C V) \mathrm{Na}_{2} \mathrm{~S}_{2} \mathrm{O}_{3}$ - концентрація розчину тіосульфату натрію; $M\left(\mathrm{O}_{3}\right)_{\text {екв }}$ еквівалентна маса озону; $V_{\text {к }}$ - об'єм розчину залитий у склянку Дрекселя; $V_{\text {п }}$ об'єм піпетки, тобто кількість відібраного розчину (проба).

Результати та їх обговорення. На основі попередніх досліджень було запропоновано апаратурно-технологічну схему (рис. 2) переробки НФ пермеату [6].

Молочна сироватка після ванн направляється на станцію НФ, де відбувається iї розділення на НФ пермеат і концентрат. Останній, із вмістом сухих речовин $20 \pm 3 \%$, направляється на остаточне згущення у вакуум-випарні апарати 
та сушиться. Отриманий НФ пермеат подається на станцію озонування, де він у контактній ємності обробляється озоном. Це сприяє окисленню органічних сполук та повній дезинфекції розчину. Встановлено, що поєднання процесу озонування та подальшої сорбційної очистки дає змогу зменшити ХСК у НФ пермеаті на 96\% [7; 8]. Проте у попередніх дослідженнях не було визначено коефіцієнт використання озону в апараті озонування, передану дозу озону (TOD) та кількість залишкового озону $\left(\mathrm{C}\left(\mathrm{O}_{3}\right)\right)$ в обробленому НФ пермеаті, що потребувало проведення відповідних експериментів.

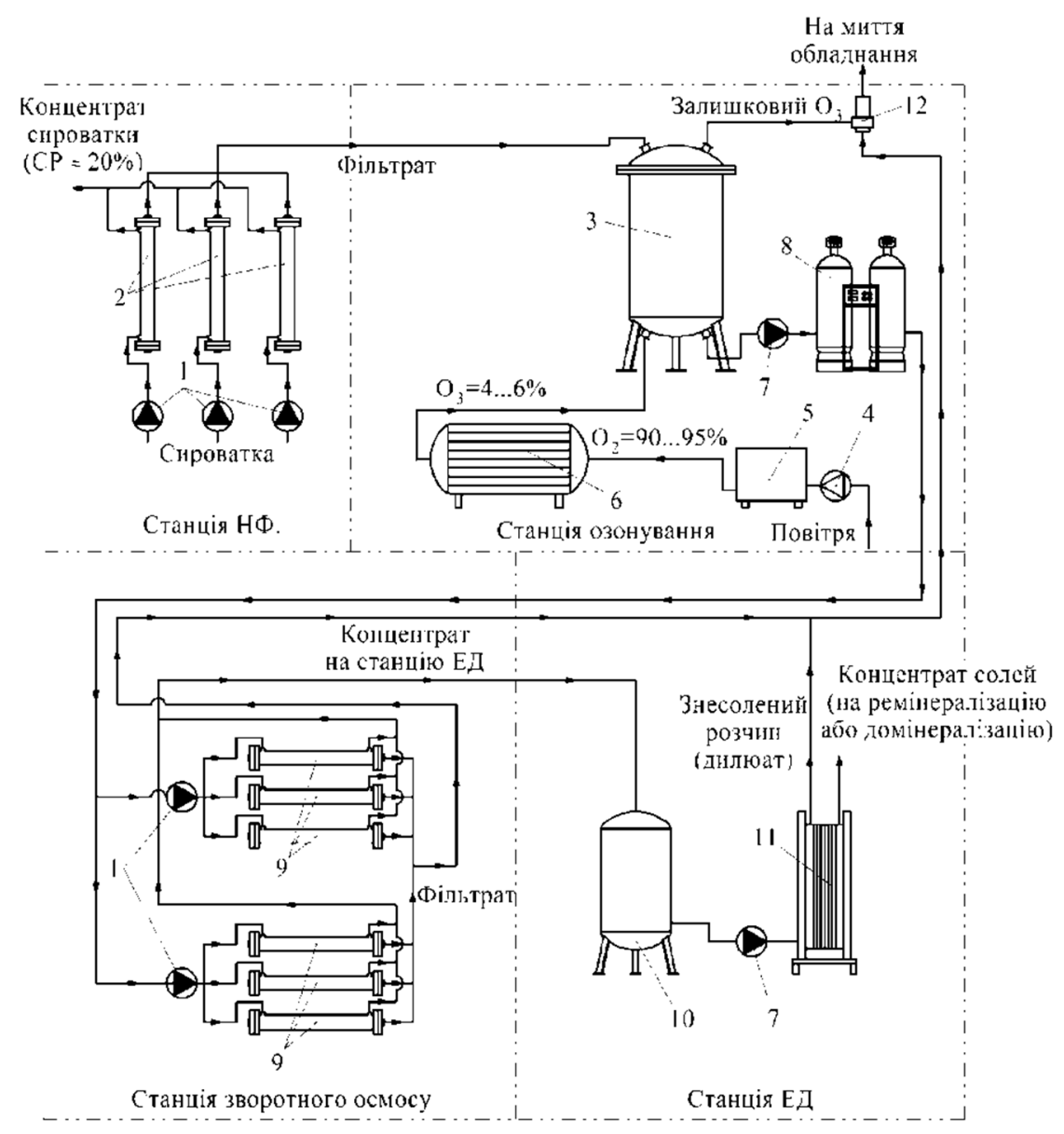

Рис. 2. Схема використання НФ пермеату молочної сироватки:

1 - насос високого тиску; 2 - апарат нанофільтрації; 3 - контактний апарат (апарат озонування); 4 - компресор для повітря; 5 - концентратор кисню; 6 - озонатор;

7 - насос; 8 - вугільний фільтр; 9 - апарат зворотного осмосу; $10-$ - збірник перед ЕД;

11 - апарат ЕД; 12 - змішувач; СР — сухі речовини; ЕД - електродіаліз

Під час досліджень процесу озонування застосовували НФ пермеат молочної сироватки, отриманий у лабораторних умовах. Продуктивність озонатора складала 0,2 г $\mathrm{O}_{3} /$ год, час обробки - 10 хв, температура НФ пермеату $-20 \pm 2{ }^{\circ} \mathrm{C}$. На реакцію окислення було використано 0,05 г/год. Встановлено, що коефіцієнт використання озону, склав всього 25\%. Він виражає кількість озону, яка була розчинена в обробленому розчині та вступила у реакцію тосовно загальної 
поданої кількості озону. Отримавши дані в ході нових експериментів, також було визначено TOD, який забезпечує видалення $96 \%$ органічних сполук на сорбційному фільтрі за вказаних умов. Цей показник має бути в межах $20 \ldots 28$ мг/дм³ Враховуючи, що раціональним вважається коефіцієнт використання озону в межах 40...60\% [9; 10], в подальшому слід забезпечити інтенсифікацію масообмінних процесів за рахунок конструктивних змін станції озонування для забезпечення більш повного процесу окислення. Ступінь використання озону залежить від його здатності розчинятися (розкладатись) та вступати у реакцію з іншими речовинами. Розкладання озону у воді відбувається в результаті ланцюгових реакцій, механізм ініціації яких полягає у дії розчинених речовин [10-13]. Може відбуватися як пряма реакція окислення озоном, так і окислення продуктами розпаду (рис. 3) в основному гідроксильними радикалами $\mathrm{OH}$ і киснем $\mathrm{O}_{2}$.

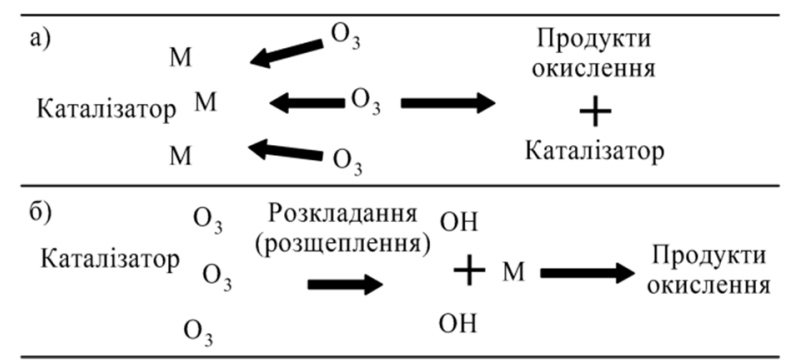

Рис. 3. а) пряме окислення озоном, б) непряме окислення продуктами розпаду озону

У разі прямого окислення відбувається окислення молекули органічної речовини озоном і на виході отримується продукт окислення та каталізатор (кисень). Найпростішим і найпоширенішим прикладом такої реакції $є$ взаємодія озону з вуглецем, продуктами взаємодії буде двоокис вуглецю та кисень:

$$
\mathrm{C}+2 \mathrm{O}_{3} \rightarrow \mathrm{CO}_{2}+2 \mathrm{O}_{2}
$$

Або взаємодія з манганом чи залізом у водному розчині:

$$
2 \mathrm{Mn}_{2}+2 \mathrm{O}_{3}+4 \mathrm{H}_{2} \mathrm{O} \rightarrow \mathrm{MnO}(\mathrm{OH})_{2}+2 \mathrm{O}_{2}+4 \mathrm{H} \text {. }
$$

У випадку окислення продуктами розпаду озону у водних розчинах спочатку відбувається розпад озону на радикали та кисень, які в подальшому вступають у реакцію з органічними компонентами.

Окислені речовини в подальшому видаляються на вугільному фільтрі (рис. 2).

Вибір процесу озонування був обумовлений тим, що озон дуже потужний окислювач, набагато більш здатний до реакції, ніж двоатомний кисень. Вироблення озону відбувається на місці його застосування і без використання будьяких додаткових реагентів. Разом 3 тим основним продуктом розпаду озону $\epsilon$ кисень, який безпечний для людини. Безпечність озону була підтверджена FDA (Food and Drug Administration - Управління із санітарного нагляду за якістю харчових продуктів та медикаментів, США).

Оброблений розчин після станції озонування та фільтрування через шар активованого вугілля піддається концентруванню на станції зворотного осмосу. За рахунок попереднього видалення органічних компонентів, продуктивність мембран зворотного осмосу підвищується на $25 . .30 \%$ [14] порівняно із способом обробки без станції озонування. При цьому збільшується кількість одержаної 
очищеної води. Отриманий концентрат йде на станцію електродіалізу (ЕД), де відбувається концентрування солей, які в подальшому можна використовуватись для домінералізації та ремінералізації питної води. Застосування ЕД обумовлене відсутністю фазового переходу оброблюваних речовин і напрямленою дією на мінеральні солі при проведенні процесу їх концентрування. Фільтрат після зворотного осмосу та дилюат після ЕД змішується із залишковим озоном, кількість якого може сягати 40...70\% від початкових значень на станції озонування, та використовується для миття обладнання. Змішування із залишковим озоном необхідне 3 двох причин: по-перше, така схема надає можливість зекономити на встановленні деструктора озону для залишкової газової суміші; по-друге, така операція дає змогу наситити розчин озоном із залишковою концентрацією $0,1 \mathrm{мг} /$ дм$^{3}$, що унеможливлює розвиток патогенної мікрофлори у такій воді впродовж $30 \ldots 60$ хв [9; 10; 15] і забезпечує ії використання для миття обладнання. Для визначення необхідних мінімальних значень TOD, за результатами експериментів, було побудовано графік залежності TOD від $\mathrm{C}\left(\mathrm{O}_{3}\right)$ (рис. 4). 3 допомогою якого було встановлено, що для досягнення мінімально необхідної за-

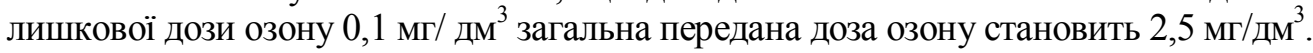

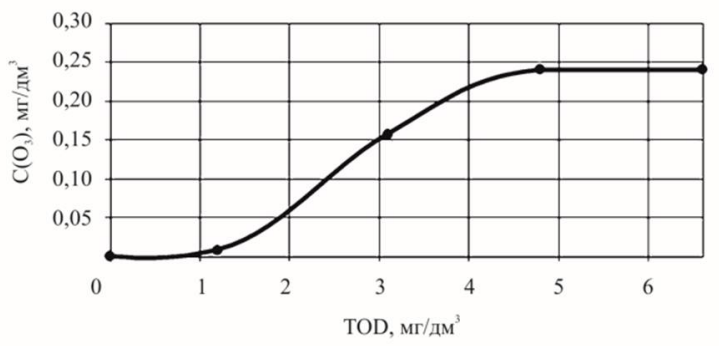

\section{Рис. 4. Співвідношення загальної переданої дози озону (TOD) до концентрації залишкового озону $\mathrm{C}\left(\mathrm{O}_{3}\right)$ у НФ перематі}

Висновки. Запропоновано схему обробки НФ пермеату, вагомою перевагою якої є практично повне використання компонентів молочної сироватки під час іiі переробки. Станція озонування дає змогувидаляти до 96\% органічних сполук НФ пермеату, для цього слід забезпечити TOD $=20 \ldots 28$ мг/дм ${ }^{3}$. Встановлено, що коефіцієнт використання озону, при озонуванні НФ перемату знаходиться в межах $25 \%$, а для мінімально необхідної залишкової дози озону 0,1 мг/дм ${ }^{3}$ TOD має бути 2,5 мг/дм ${ }^{3}$. У подальшому запропонований спосіб переробки НФ пермеату молочної сироватки може бути застосований до широкого спектра розчинів, що утворюються в технологіях харчових виробництв, з метою їх обробки та повного використання.

\section{ЛITEАТУРА}

1. Храмцов А.Г. Рациональная переработка и использование молочного белковоуглеводного сырья / А.Г. Храмцов, П.Г. Нестеренко // Молочная промышленность. M., 1998. - $105 \mathrm{c}$.

2. Храмщов А.Г. Справочник технолога молочного производства. Технологии и рецептуры. Продукты из обезжиренного молока, пахты и молочной сыворотки: в 5 Т. / А.Г. Храмцов, С.В. Василисин. - С.-Пб. : ГИОРД. - 2004. - Т. 5. - 276 с.

3. Юкало А.В. Білки казеїнового комплексу молока корови (Bos taurus) як попередники біологічно активних пептидів [Текст] / А.В. Юкало, Л.А. Сторож, В.Г. Юкало // Біотехнологія. - 2012. - Т. 5, № 4. - С. 21-33. 
4. Храмизов А.Г. Технология продуктов из молочной сыворотки: учебное пособие / А.Г. Храмцов, П. Г. Нестеренко. - М. : ДеЛи принт, 2004. - 578 с.

5. Храмциов А.Г. Феномен молочной сыворотки / А.Г. Храмцов. - СПб. : Профессия, 2011. $-804 \mathrm{c}$.

6. Пат. 113724 Україна, МПК (2006) С02F 1/78 (2006.01). Спосіб очищення стічних вод молокопереробних підприємств / Ю.Г. Змієвський, В.В. Захаров, Л.В. Корнієнко, В.Г. Мирончук; власник НУХТ, вул. Володимирська, 68, м. Київ-33, 01601. Номер заявки: u 2016 08502; дата подання заявки: 02.08.2016; дата, з якої є чинними права на корисну модель: 10.02.2017; опубліковано: 10.02.2017, Бюл. № 3.

7. Озонування рідин молочної промисловості / В.В. Захаров, Ю.Г. Змієвський, I.М. Білецька, В.Г. Мирончук. // Наукові праці Національного університету харчових технологій. - Київ. - 2017. - Том 23, № 5, Ч. 1. - С. 124-130.

8. Захаров В.В. Обробка промислових стоків молокопереробних підприємств озоном. Попередні результати. / В.В. Захаров, Ю.Г. Змієвський, В.Г. Мирончук // Вісник харківського національного технічного університету сільського господарства імені Петра Василенка «Сучасні напрямки технології та механізації процесів переробних і харчових виробництв». - Харків, 2016. - С. 167-173.

9. Коженов В.Ф. Установки для озонирования воды. - М. : Стройиздат, 1968. - $171 \mathrm{c.}$

10. Degremont. Технический справочник по обработке воды. Том 1. / [L. Andriamirado, D. Asensi, S. Baig та ін.]. - Спб. : Новый журнал, 2007. - 878 c.

11. Degremont. Технический справочник по обработке воды. Том 2. / [L. Andriamirado, D. Asensi, S. Baig та ін.]. - Спб. : Новый журнал, 2007. — 920 с.

12. Лунин В.В. Физическая химия озона. / В.В. Лунин, М.П. Попович, С.Н. Ткаченко. - М. : Издательствово Московского университета, 1998. - 578 с.

13. Shigezo N. Ozone Contribution in Food Industry in Japan / N. Shigezo, H. Takahara. // Ozone: Science and Engineering. - 2006. - №28. - C. 425-429.

14. Ozonation of nanofiltration permeate of whey before processing by reverse osmosis / [Y.G. Zmievskii, V.V. Zaharov, O.S. Rudenko та ін.]. // Acta periodica technologica. — 2017. — № 48. - C. 315-323.

15. ДСТУ 2.2.4-171-10. «Вода питна. Вимоги та контроль».

\title{
РАЗРАБОТКА СХЕМЫ ПЕРЕРАБОТКИ НАНОФИЛЬТРАЦИОННОГО ПЕРМЕАТА МОЛОЧНОЙ СЫВОРОТКИ
}

\author{
В.В. Захаров, Ю.Г. Змиевский, В.Г. Мирончук \\ Национальный университет пищевых технологий \\ Ю.С.Дзязько \\ Институт общей и неорганической химии им. В.И. Вернадского НАН Украины
}

В работе предложен и научно обоснован способ эффрективной переработки нанофильтрационного пермеата молочной сыворотки путем использования процессов озонирования и электродиализа. Определен коэффрициент использования озона в контактном аппарате, который составляет 25\%. Получена зависимость остаточного озона $\mathrm{C}\left(\mathrm{O}_{3}\right)$ от общей передаваемой дозы озона (TOD). Установлено, что для достижения постефекта предотвращения развития микрофрлоры в обработанном нанофильтрационном пермеате мини-

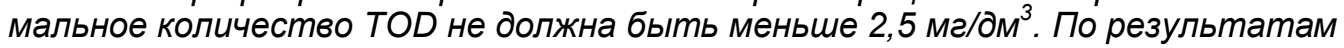
работы предложено малоотходную схему переработки нанофильтрационного пермеата молочной сыворотки.

Ключевые слова: озон, станция озонирования, молочная сыворотка, нанофильтрационный пермеат, органические соединения, сухие вещества, деминерализация. 
УДК 637.5 .03

\title{
APPLICATION OF THE MANYBLADES TOOL FOR MILLING OF FROZEN MEAT BLOCKS
}

\author{
I. Oshchypok \\ Lviv University Trade and Economic
}

\begin{tabular}{|c|c|}
\hline Key words: & ABSTRACT \\
\hline $\begin{array}{l}\text { meat, } \\
\text { blocks, } \\
\text { frozen, } \\
\text { cutting, } \\
\text { milling, } \\
\text { power }\end{array}$ & $\begin{array}{l}\text { The article deals with the most rational technological } \\
\text { parameters of cutting frozen block meat of two species (beef and } \\
\text { pork) with a multifarious instrument. The main focus of research } \\
\text { is the study of the application of mills of different designs, as the } \\
\text { working organ of the chopper. The obtained results can be used to } \\
\text { calculate the specific energy consumption per unit area of the }\end{array}$ \\
\hline $\begin{array}{l}\quad \text { Article history: } \\
\text { Received } 30.03 .2018 \\
\text { Received in revised form } \\
\text { 15.04.2018 } \\
\text { Accepted } 28.05 .2018\end{array}$ & $\begin{array}{l}\text { layer of meat that is removed simultaneously with cutting teeth } \\
\text { cutters. The data of this calculation will allow to estimate the } \\
\text { necessary power of the drive of the cutting tool of the milling } \\
\text { machine intended for grinding blocks of frozen meat of industrial } \\
\text { sizes and to determine the design parameters of mills. }\end{array}$ \\
\hline $\begin{array}{l}\text { Corresponding author: } \\
\text { him1960@ukr.net }\end{array}$ & $\begin{array}{l}\text { The obtained results can be used to calculate the specific } \\
\text { energy consumption per unit area of the layer of meat that is } \\
\text { removed simultaneously with cutting teeth cutters. The data of } \\
\text { this calculation will allow to estimate the necessary power of } \\
\text { the drive of the cutting tool of the milling machine, intended for } \\
\text { grinding blocks of frozen meat of industrial sizes, and to } \\
\text { determine the design parameters of milling cutters. } \\
\text { It can be argued that the moment of resistance of the } \\
\text { grinding, that is, the load on the cutter in operating mode, varies } \\
\text { significantly by size. This is due to the considerable heteroge- } \\
\text { neity of the raw material. When changing the load on the cutter } \\
\text { cutter in the operating mode changes the frequency of its ro- } \\
\text { tation, which leads to an additional dispersion of linear dimen- } \\
\text { sions of meat chips due to changes in the parameters of the } \\
\text { cutting mode (feeding on the tooth cutters and cutting speed of } \\
\text { raw materials). In view of this, it is necessary to ensure that the } \\
\text { parameters of the cutting mode by means of the automatic } \\
\text { control system (ACS) are stabilized by the grinding process in } \\
\text { the working mode of the chopper. The structure of the ACS by } \\
\text { the process of grinding the frozen meat raw with a mill with the } \\
\text { use of a control computer is proposed in the work. }\end{array}$ \\
\hline
\end{tabular}

DOI: $10.24263 / 2225-2916-2018-23-14$

\section{ЗАСТОСУВАННЯ БАГАТОЛЕЗНОГО ІНСТРУМЕНТУ ДЛЯ ПОДРІБНЕННЯ ЗАМОРОЖЕНИХ М'ЯСНИХ БЛОКІВ}

\author{
I.М. Ощипок, д-р техн. наук \\ Львівський торговельно-економічний університет \\ У статmі розглянуто найбільш раціональні технологічні параметри різання \\ замороженого блочного м'яса двох видів (яловичини і свинини) багатолезним
}

(C) I.M. Ощипок, 2018 
інструментом. Основним напрямком досліджень вибрано вивчення застосування фррез різної конструкції як робочого органу подрібнювача. Оцінено технологічні й експлуатаційні характеристики оброблюваних матеріалів, визначено потужність і енерговитрати процесів обробки від умов фррезерування залежно від ряду фракторів: площі дотику фрези до блоку м'яса, діаметра фррези, кількості зубів, кута нахилу зубів, подачі на зуб, кількості обертів, які зробила фрреза з моменту початку різання, блоку м'яса, до досліджуваного моменту. Отримані результати можуть бути використані для розрахунку питомих енерговитрат, що припадають на одиницю площі шару м'яса, що знімається одночасно ріжучими зубами фррези. Запропоновано обгрунтовані технічні й технологічні рішення з оцінки ефрективності та економічної доцільності прийнятних розв'язків у питанні подрібнення замороженого м'яса.

Ключові слова: м'ясо, блоки, морожені, різання, фрреза, потужність.

Постановка проблеми. Технологічна підготовка нових i модернізація існуючих виробництв, розробка нового обладнання обумовлює необхідність прийняття обгрунтованих технічних і технологічних рішень 3 оцінки ефективності та економічної доцільності прийнятих розв'язків у питанні подрібнення замороженого м'яса. Це супроводжується виконанням великого обсягу організаційних і технічних робіт, в складі яких значне місце займають випробувальні і дослідні роботи, Процес подрібнення сировини є одним з найбільш енергоємних технологічних процесів м'ясної промисловості.

Аналіз останніх досліджень і публікацій. Подрібнення замороженого м'яса багатолезним інструментом має свої особливості і в повному обсязі ще не вивчено [1-3]. Зокрема, необхідно визначити енерговитрати на процес подрібнення замороженої м'ясної сировини фрезами й обгрунтувати параметри фрез залежно від умов їх роботи, тобто від умов фрезерування.

Заморожені блоки м'яса характеризуються суттєвою неоднорідністю за структурними і текстурними ознаками. Крім того, температура сировини перед подрібненням неоднакова в глибині блоку м'яса і на його поверхні. Ці фактори впливають на момент опору подрібнення як функції часу i, отже, на споживану потужність, мають стохастичний характер. У зв'язку з цим доцільно провести статистичний аналіз виміряних значень потужності, яку споживає привід механізму різання фрезерного подрібнювача [4-7].

Основним напрямком досліджень вибрано вивчення застосування фрез як робочого органу подрібнювача заморожених м'ясних блоків. Обгрунтовується такий вибір можна тим, що:

1) при подрібненні сировини фрезами площа контакту ріжучих крайок 3 м'ясом мінімальна порівняно з площею бічних поверхонь ножів кутера, тому можна забезпечити зниження енерговитрат на тертя й адгезію;

2) змінюючи параметри процесу подрібнення сировини методом фрезерування і застосовуючи змінні фрези різної конструкції і геометрії, можна впливати на формування розмірів частинок подрібненого м'яса, забезпечуючи заданий ступінь подрібнення сировини при підвищенні якості готових м'ясопродуктів;

3) переробляючи блоки замороженого м'яса промислових типорозмірів методом фрезерування в одну стадію, можна скоротити традиційний технологічний ланцюг переробки блочного м'яса (блокорізка-вовчок-кутер), що забезпечить ресурсозбереження та зниження витрат електроенергії в розрахунку на тонну вироблюваної продукції. 
Мета дослідження: виявити найбільш раціональні технологічні параметри різання замороженого блочного м'яса багатолезним інструментом. Оцінка технологічних і експлуатаційних характеристик оброблюваних матеріалів; визначення потужності й енерговитрат процесів обробки від умов фрезерування, залежно від ряду факторів: площі дотику фрези до блоку м'яса, діаметра фрези, кількості зубів, кута нахилу зубів, подачі на зуб, кількості обертів, які зробила фреза з моменту початку різання, блоку м'яса, до досліджуваного моменту.

Матеріали і методи. Подрібнення різних експериментальних блоків замороженого м'яса двох видів (яловичина і свинина). Загальне число замірів потужності (обсяг вибірки) складає 36 значень. Згрупування статистичного ряду даних замірів споживаної потужності електродвигуном приводу механізму різання фрезою. Розрахунок щільності частоти за діапазонами значень споживаної потужності, чисельного розподілу влучень величини споживаної потужності електродвигуном приводу механізму різання фрези в обрані діапазони ії значень, щільності і частоти розподілу потужності, споживаної електродвигуном приводу механізму різання установки 3 фрезою в робочому режимі за діапазонами іï виміряних значень.

Результати досліджень. Розглянемо зміну площі поперечного січення стружки і дотичні зусилля різання, які відносяться до леза фрези залежно від умов її роботи, тобто від умов фрезерування. Площа поперечного січення стружки, яка знімається одночасно зубами фрези, залежить від ряду факторів: площі дотику фрези до блоку м'яса $S$, діаметра фрези $d$, кількості зубів $z$, кута нахилу зубів $\beta$, подачі на зуб $U_{z}$, кількості обертів $n$, які зробила фреза 3 моменту початку різання, блоку м'яса, до досліджуваного моменту.

Дослідимо роботу фрези з прямими зубами. При цьому товщина стружки, яку знімає один ніж, однакова по всій довжині леза і визначається залежністю:

$$
E=U_{z} \cdot \sin \varphi,
$$

де $E$ - товщина стружки, яку знімає ніж, м; $\varphi$ - миттєве значення кута контакту леза з блоком м'яса в діапазоні від 0 до $180^{\circ}$. У початковий період роботи кут $\varphi$ буде дорівнювати:

$$
\varphi=90 \pm \varphi_{1},
$$

де $\varphi_{1}=\arccos \frac{r-U_{z} n_{z}}{r} ; r-$ радіус фрези, м.

Довжину стружки м'яса, яка знімається в період роботи фрези для $n$-го різця, визначимо із залежності:

$$
b_{n}=2 \sqrt{S^{2}-\left(S-U_{z} n z\right)^{2}},
$$

де $b_{n}$ - довжина стружки м'яса, м; $S$ - площа контакту фрези із замороженим блоком м'яса, ${ }^{2} ; n-$ порядковий номер різця.

Площу поперечного січення, яка знімається за один раз лезом фрези, можна визначити як площу сегмента (перший раз) і в подальшому як площу зсіченого сегменту. Для спрощення розрахунків, 3 незначною втратою точності площі поперечного січення стружки, яка знімається, можна обчислити як площу трикутника (перший раз) і як площу трапеції (всі наступні різи) із залежності: 


$$
\begin{gathered}
F_{n}=\frac{b_{n}+b_{n-1}}{2} U_{z} \sin \varphi= \\
=\left[\sqrt{S^{2}-\left(S-U_{z} n_{z}\right)^{2}}+\sqrt{S^{2}-\left(S-U_{z}(n-1) z\right)^{2}}\right] U_{z} \sin \varphi,
\end{gathered}
$$

де $F_{n}$ - площа поперечного січення, яка знімається за один раз лезом фрези, м².

Дотичне зусилля різання для цього випадку дорівнює:

$$
P_{n}=F_{n} K_{f}
$$

де $P_{n}$ - дотичне зусилля різання замороженого блоку м'яса, $\mathrm{H} ; K_{f}$ - питоме зусилля різання, $\mathrm{H} / \mathrm{M}^{2}$.

У розглядуваному випадку фрезерування проходить як поздовжньо-торцеве різання м'яса, причому питомі зусилля різання суттєво залежать від кута зустрічі леза з волокнами м'яса. Питомі зусилля різання визначимо таким чином:

$$
K_{f}=K_{p} \cos ^{2} \psi+K_{n} \sin ^{2} \psi
$$

де $K_{p}$ - питоме зусилля різання м'яса вздовж волокон, Н/м²; $K_{N}$ - питоме зусилля різання м'яса перпендикулярно до волокон, Н/м²; $\Psi=90-\varphi$.

Підставивши значення $\psi$ в рівняння (6), отримаємо:

$$
K_{f}=K_{p} \sin ^{2} \varphi+K_{n} \cos ^{2} \varphi .
$$

Підставляючи тримані значення $F_{n}$ і $K_{f}$ у (5), отримаємо:

$$
\begin{gathered}
P n=\left(\sqrt{S^{2}-\left(S-U_{z} n z\right)^{2}}+\sqrt{S^{2}-\left(S-U_{z}(n-1) z\right)^{2}}\right) \times \\
\times U_{z} \sin \varphi^{*}\left(K_{p} \sin ^{2} \varphi+K_{n} \cos ^{2} \varphi\right) .
\end{gathered}
$$

Дані вимірювань потужності [1-3] будемо розглядати як єдину статистичну вибірку даних. Це обумовлено тією обставиною, що статистичний аналіз споживаної потужності слід провести для всіх випадків експериментального подрібнення фрезою одного типу.

За отриманими експериментальними даними побудуємо гістограму чисельного розподілу влучень величини потужності, споживаної електродвигуном приводу механізму різання фрези, в обрані діапазони іiі значень (рис. 1).

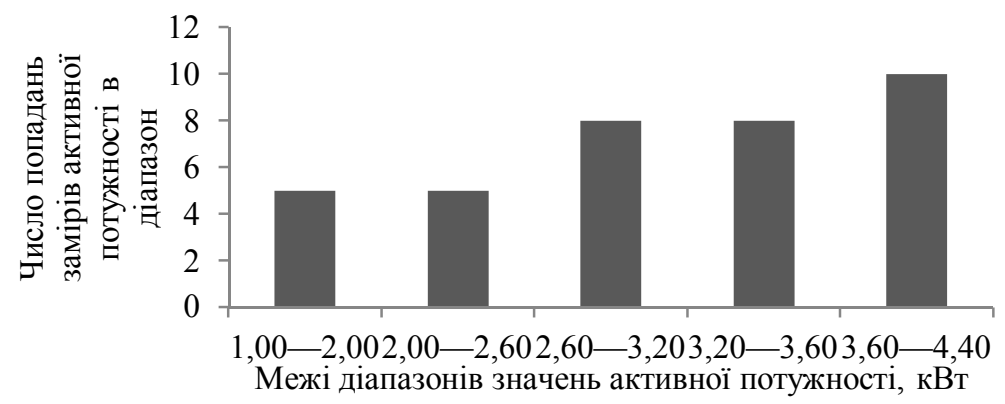

Рис. 1. Гістограма чисельного розподілу влучень величини споживаної потужності електродвигуном приводу механізму різання фрези в обрані діапазони їі значень 
Розрахуємо щільності частоти за діапазонами значень споживаної потужності.

Побудуємо гістограму щільності частоти розподілу потужності, споживаної в процесі подрібнення, в обрані діапазони іï значень (рис. 2).

На відміну від гістограми чисельності розподілу влучень величини потужності в обрані діапазони ії значень (рис. 1), тут ми отримуємо об'єктивну картину експериментального розподілу потужності як випадкової величини, усуваючи фактор суб'єктивного вибору границь діапазонів [5]. 3 огляду на гістограму, наведену на рис. 2 , можна припустити, що закон розподілу потужності близький до закону Гаусса.

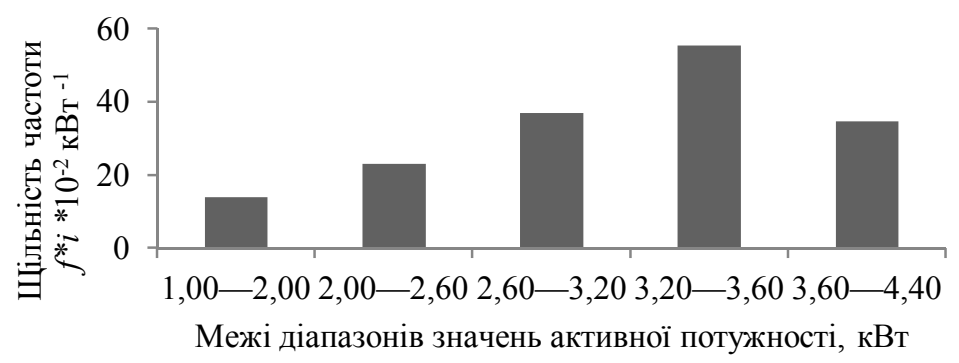

Рис. 2. Гістограма щільності частоти розподілу потужності, споживаної електродвигуном приводу механізму різання установки з фрезою в робочому режимі за діапазонами ї̈ виміряних значень

Оцінимо правдоподібність цієї гіпотези розрахунковим шляхом. Обчислимо оцінки числових характеристик дослідного розподілу потужності, споживаної в процесі подрібнення:

$$
m_{N}^{*}=\sum_{i=1}^{k} N_{i c p} * p_{i}^{*}=3,07(\kappa B m)
$$

де $m^{*}{ }_{N}$ - оцінка математичного очікування дослідного розподілу; $N_{i c p}-$ середнє значення потужності в і-му діапазоні; $p_{i}^{*}-$ частота потрапляння в $i$-й діапазон; $k$ - число діапазонів.

$$
\sigma_{N}^{*}=\sqrt{D_{N}^{*}}=\sqrt{a_{2}-\left(m_{N}^{*}\right)^{2}}=0,789(\text { кВт }),
$$

де $\sigma{ }_{N}$ - оцінка середнього квадратичного відхилення дослідного розподілу; $D{ }_{N}$ - оцінка дисперсії дослідного розподілу; $\alpha_{2}$ - початковий момент другого порядку дослідного розподілу споживаної потужності в процесі подрібнення.

Висунемо гіпотезу, що дослідний статистичний розподіл споживаної потужності електродвигуном приводу механізму різання подрібнювача з фрезою підпорядковується нормальному закону з обчисленими вище параметрами:

$$
\begin{gathered}
f(a)=\left[\frac{1}{\sigma \sqrt{2 \Pi}}\right] \exp \left[-\frac{\left(a-m^{2}\right)}{\left(2 * \sigma^{2}\right)}\right]= \\
=\left[\frac{1}{(0,789 * \sqrt{2 \Pi})}\right] * \exp \left[-\left(a-3,07^{2}\right) /(2 * 0,622)\right] .
\end{gathered}
$$


Перевірку правдоподібності висунутої гіпотези здійснимо, використовуючи критерій Пірсона. У табл. 3 наведені ймовірності попадання потужності в діапазони їі значень, обчислені по гіпотетичному розподілу.

Таблиия 3. Імовірність попадання значень потужності за гіпотетичним розподілом в обраному діапазоні

\begin{tabular}{|c|c|c|c|c|c|}
\hline $\begin{array}{c}\text { Межі діапазону значень потужності, } \\
\text { кВт }\end{array}$ & $1,00-2,00$ & $2,00-2,60$ & $2,60-3,20$ & $3,20-3,60$ & $3,60-4,40$ \\
\hline Імовірність & 0,0824 & 0,1873 & 0,2933 & 0,1811 & 0,2059 \\
\hline
\end{tabular}

Обчислимо значення критерію Пірсона:

$$
\chi^{2}=\sum_{i=1}^{k} \frac{\left(n_{i}-n \cdot p_{i}\right)^{2}}{\left(n \cdot p_{i}\right)} \cong 3,70
$$

де $i$ - номер діапазону значень потужності; $k-$ число діапазонів; число значень потужності в $i$-му діапазоні; $n-$ число вимірювань $n=36, \Sigma n_{i}=n ; p_{i}$ імовірність попадання значення потужності по гіпотетичного розподілу в $i$-й діапазон.

Табличне значення критерію Пірсона для рівня значущості 0,1 при трьох незалежних умовах і числі ступенів свободи одне: $r=k-3=5-3=2$ [8]: $\chi_{\text {mабл }}^{2}=4,60$. Тож при прийнятих умовах розраховане значення критерію Пірсона менше за табличне значення $(3,70<4,60)$. Отже, гіпотезу про нормальний розподіл активної потужності, споживаної електродвигуном приводу механізму різання подрібнювача 3 фрезою в процесі подрібнення як випадкової величини, можна вважати такою, що не суперечить дослідним даним.

Результати обчислень дають змогу припустити на підставі центральної граничної теореми, що стохастичні фактори (неоднорідність сировини по текстурних і структурних ознаках, зміни температури сировини в об'ємі блоку м'яса) мають рівнозначний вплив на енерговитрати процесу подрібнення блочного замороженого м'яса за методом фрезерування.

Висновки. Отримані результати можуть бути використані для розрахунку питомих енерговитрат, що припадають на одиницю площі шару м'яса, що знімається одночасно ріжучими зубами фрези. Дані цього розрахунку дають змогу оцінити потрібну потужність привода ріжучого механізму фрезерної машини, призначеної для подрібнення блоків замороженого м'яса промислових типорозмірів, і визначити конструктивні параметри фрез.

Можна стверджувати, що момент опору подрібнення, тобто навантаження на фрезу в робочому режимі, істотно змінюється за величиною. Це пояснюється значною неоднорідністю вихідної сировини. При зміні навантаження на фрезу подрібнювача в робочому режимі змінюється частота їі обертання, що призводить до додаткової дисперсії лінійних розмірів м'ясної стружки в зв'язку зі зміною параметрів режиму різання (подачі на зуб фрези і швидкості різання сировини). 3 огляду на це слід забезпечити стабілізацію параметрів режиму різання засобами системи автоматичного управління (САУ) процесом подрібнення в робочому режимі подрібнювача. Структура САУ процесом подрібнення замороженого м'ясної сировини фрезою з використанням керуючої обчислювальної машини запропонована в статті. 


\title{
ЛІТЕРАТУРА
}

1. Ивашов В.И. Современная практика переработки замороженного мясного сырья. [Текст] // В.И. Ивашов, А.Н. Захаров, А.Б. Лисицын, Б.Р. Каповский, О.Е. Кожевникова // Bсе о мясе. - 2014, — № 2. - С. 24-29.

2. Лисицььн А.Б. Измельчение замороженного блочного мяса методом фрезерования [Текст] / А.Б. Лисицын, В.И. Ивашов, А.Н. Захаров, Б.Р. Каповский, Д.А. Максимов // Всё о мясе. - 2013. - № 4. - С.42-48.

3. Лисищын А.Б. Интеллектуальная система управления качеством мясных фаршей [Текст] / А.Б. Лисицын, В.И. Ивашов, А.Н. Захаров, Б.Р. Каповский, О.Е. Кожевникова // Всё о мясе. - 2013. - № 6. - С. 32-38.

4. Белов, М.П. Автоматизированный електропривод типовых производственных механизмов и технологических комплексов / М.П. Белов, В.А. Новиков, Л.Н. Рассудов. Москва : Издательский центр «Академия», 2004. — 576 с.

5. Максимов, Д.А. Автоматическое управление процессом тонкого измельчения мясного сырья [Текст] / Д.А. Максимов, Б.Р. Каповский, А.Н. Захаров // Мясная индустрия. 2013. - № 1. - С. 42-46.

6. Aktuelles aus der Fleischforschung Kurzfassungen der Fachvortzge von der 49 Kulmbacher Wochevom 6. bis. 8 // Fleischwirtschaft. — 2014. — № 6. - S. 84.

\section{ПРИМЕНЕНИЕ МНОГОЛЕЗВИЙНОГО ИНСТРУМЕНТА ДЛЯ ИЗМЕЛЬЧЕНИЯ ЗАМОРОЖЕННЫХ МЯСНЫХ БЛОКОВ}

\author{
И.Н. Ощипок \\ Львовский торгово-экономический университет
}

В статье рассмотрены наиболее рациональные технологические параметры резки замороженного блочного мяса двух видов (говядины и свинины) многолезвийным инструментом. Основным направлением исследований выбрано изучение применения фррез различной конструкции как рабочего органа измельчителя. Оценены технологические и эксплуатационные характеристики обрабатываемых материалов, определена мощность и энергозатраты процессов обработки; от условий фррезерования в зависимости от ряда фракторов: площади соприкосновения фррезы о блок мяса, диаметра фррезы, количества зубов, угла наклона зубьев, подачи на зуб, количества оборотов, которые сделала фрреза с момента начала резки, блока мяса, к исследуемому моменту. Полученные результаты могут быть использованы для расчета удельных энергозатрат, приходящихся на единицу площади слоя мяса снимаемого одновременно режущими зубъями фррезы. Приняты обоснованные технические и технологические решения по оценке эфрфективности и экономической целесообразности приемлемых решений в вопросе измельчения замороженного мяса.

Ключевые слова: мясо, блоки, мороженые, резки, фреза, мощность. 
УДК $621.7: 637.5$

\title{
SHELF LIFE EXTENSION OF CHILLED MEAT AND SEMI-FINISHED MEAT PRODUCTS BY VACUUM PACKAGING
}

\author{
V. Pasichnyi, O. Khrapachov, A. Marynin, R. Svyatnenko \\ National University of Food Technologies \\ A. Geredchuk \\ Poltava University of Economics and Trade
}

Key words:
chilled meat,
vacuuming,
multilayer heat-shrinkable
materials,
guaranteed quality,
shelf-life

Article history:

Received 21.03.2018

Received in revised form

20.04.2018

Accepted 20.05.2018

Corresponding author:

pasww1@ukr.net

\begin{abstract}
Chilled meat is one of the most popular and widespread products, which is in great demand on the consumer's market, both in its natural and semi-finished form.
\end{abstract}

One of the negative factors that reduces marketable state and shelf life of the product is exudation of moisture, which concentrates between the product and the inner surface of the package under vacuum. To reduce this effect, it was proposed to carry out the packing of lump semi-finished products under vacuum with the use of thermo-shrinkable materials. For research, meat and bone lumpy types of semi-finished products were made, since they have the smallest product surface contact area with packaging (in comparison with dice products of the same total weight), minimum production time, presence of connective and fat tissue on their surface, which also contributes to reduction of exudation of excessive moisture during the process of packing and storage. A very important factor is the strict observation of the product temperature that is being packed with the subsequent heat-holding: the lower the temperature of the product, the longer its final shelf-life. It is recommended to have a product temperature close to $0^{\circ} \mathrm{C}$, which allows avoiding such negative phenomenon as protein coagulation on product surface. The shelf-life was studied on the basis of organoleptic and microbiological index at the end of the technological process (background values) on 20,23, 27, 30 and 35 days of storage.

The research proved shelf-life of chilled meat and semifinished products made of it with using of modern packing materials. The research results allowed to confirm and recommend extended terms of storage of chilled meat on semi finished products made of it, which are vacuum-packed with the following heat-holding: for lump products - 28 days maximum, for meat-and-bone products - 21 days maximum. The research data was taken into account when developing changes to the normative and technological documentation for the relevant products.

DOI: $10.24263 / 2225-2916-2018-23-15$ 


\title{
ПАКУВАННЯ ПІД ВАКУУМОМ ЯК СПОСІБ ПОДОВЖЕННЯ ТЕРМІНІВ ЗБЕРІГАННЯ ОХОЛОДЖЕНОГО М'ЯСА ТА НАПІВФАБРИКАТІВ 3 НЬОГО
}

\author{
В.М. Пасічний, д-р техн. наук \\ O.В. Храпачов, аспірант \\ A.I. Маринін, канд.техн.наук \\ P.C. Святненко, науковий співробітник \\ Національний університет харчових технологій \\ А.М. Гередчук, канд.техн.наук. \\ Полтавський університет економіки і торгівлі
}

Дослідженнями обгрунтовано раціональні терміни зберігання охолодженого м'яса і напівфрабрикатів з нього з використанням сучасних пакувальних матеріалів. Результати досліджень дали змогу підтвердити і рекомендувати продовжені терміни зберігання охолодженого м'яса напівфабрикатів з нього, які упаковані під вакуумом з таким проведенням термоосадження: для крупнокускових - не більше 28 діб, для м'ясо-кісткового - не більше 21 діб.

Визначено, що упаковка охолодженого м'яса під вакуумом доцільна для крупнокускових напівфабрикатів. Крім того, зберігання в модифікованому газовому середовищі краще підходить для сімейного або порціонного пакування, де важливий привабливий зовнішній вигляд $і$ зберігання первинної форми й текстури продукту, а також відсутність помітного виділення вологи.

Ключові слова: охолоджене м'ясо, вакуумування, багатошарові термозсідальні матеріали, гарантована якість, термін зберігання.

Постановка проблеми. Охолоджене м'ясо є чи не одним з найпопулярніших продуктів, що користується попитом не одне десятиріччя. Це пов'язане з тим, що переважна більшість покупців надає перевагу свіжому або охолодженому продукту, цінуючи його якісні показники та відсутність можливого багаторазового заморожування. При цьому багато з них довіряють продукту, який виготовлений запакований безпосередньо на м'ясопереробному підприємстві, розуміючи, що саме так можна отримати якісний продукт з стабільними споживчими властивостями [1].

На сьогодні відомо два варіанти пакування охолодженого м'яса та напівфабрикатів з нього із застосуванням багатошарових полімерних матеріалів, а саме: під вакуумом і в модифікованому газовому середовищі (МГС), кожен з яких має свої особливості, оскільки не існує одного універсального способу пакування для всього асортименту зазначеної продукції $[1 ; 2]$.

Якщо розрізняти за термінами зберігання м'ясопродуктів, то без сумніву перевагу отримає пакування під вакуумом, а якщо за зовнішнім виглядом та презентабельністю продукту — найкраще підходить МГС. Слід зауважити, що пакування охолодженого м'яса під вакуумом доцільне для великошматкових напівфабрикатів, відрубів (в тому числі як транспортне пакування), а пакування в модифікованому газовому середовищі краще підходить для сімейної або порційної упаковки, де важливий привабливий зовнішній вигляд та зберігання первинної форми і текстури продукту, а також відсутність помітного виділення вологи [1]. При виборі системи пакування важливо приймати до уваги такі фактори: бажані терміни зберігання, тип продукту, що підлягає пакуванню, систему транспортування від підприємства до місця реалізації та їх віддаленість між собою [3].

Серед основних вимог, що ставляться перед виробниками охолоджених м'ясних напівфабрикатів, $є$ : чітке дотримання санітарних норм і правил на стадіях 
підготовки, розробки, знежилування та пакування напівфабрикату; мінімізація часу на проведення операцій; підтримання низького температурного ланцюга на всіх етапах переробки, пакування, зберігання, транспортування та реалізації продукції [3; 6]. Вагомим фактором є також контроль рівня рН та врахування впливу вищезазначених умов на процес виділення м'ясного соку, що пов'язаний 3 таким показником, як активність води $\left(a_{w}\right)$.

Встановлено, що від рівня $a_{w}$ залежить інтенсивність життєдіяльності мікроорганізмів, швидкість окислення, неферментативного потемніння, ферментація, структурні та структурно-механічні властивості продукту [8]. Чим нижче значення $a_{w}$, тим тривалішим $\epsilon$ термін придатності продукту [4], ефективним також $\epsilon$ використання в поєднанні 3 регулюванням $a_{w}$ антиоксидантів і олеорезинів спецій [9; 10].

Зміна кольору м'яса залежить, в основному, від наявності пігменту міоглобін. Окислення міоглобіну є зворотним процесом, і після відкривання вакуумної упаковки м'ясо вступає в контакт з киснем повітря та знову набуває свого звичайного ярко-червоного кольору [3].

Оскільки подовження термінів зберігання охолодженого м'яса є актуальним питанням сьогодення, що пов'язано із значним розширенням географії збуту даної продукції як на теренах нашої держави, так і за іії межами, було запропоновано розглянути можливість їх збільшення без використання консервуючих речовин хімічного або природнього походження.

Враховуючи, що при транспортуванні даного виду продукції, що запакована в МГС, є цілий ряд обмежень і вона має порівняно невеликий термін зберігання, для досягнення необхідного результату було вирішено йти шляхом розвитку напрямку в пакувальній та м'ясопереробній індустрії, як пакування під вакуумом.

Одним із небажаних факторів, що призводить до зниження товарного виду продукту, зменшення терміну його реалізації, $є$ виділення вологи 3 продукту, відбувається під дією зовнішнього тиску [5], що також впливає на органолептичні показники продуктів при їх ранговому оцінюванні [7].

Для зниження даного ефекту при пакуванні готових м'ясопродуктів використовують пакування в вакуумні термозсідальні матеріали (пакети, плівки). Такий напрямок було використано і для пакування охолодженого м'яса яловичини, телятини, свинини, баранини та напівфабрикатів 3 них, враховуючи анатомічні властивості сировини при їі розробці та жилуванні.

Мета дослідження: визначення зміни характеристик м'ясних напівфабрикатів у процесі зберігання з використанням пакувальних матеріалів для обгрунтування їх термінів зберігання.

Матеріали і методи. Для досліджень були виготовлені великошматкові та м'ясокісткові види напівфабрикатів, тому що саме ці види мають найменшу площу контакту поверхні продукту з пакувальним матеріалом (порівняно 3 дрібношматковими 3 тією ж загальною вагою), мінімальний час на їх виготовлення, наявність сполучної та жирової тканини на своїй поверхні, що також сприяє зниженню виділенню надмірної кількості вологи в процесі пакування та зберігання.

Після розробки напівтуш, які мали температуру в товщі м'язів від 0 до $4^{\circ} \mathrm{C}$, відповідні відруби м'яса (окіст, лопатка, тазостегнова частина тощо) зачищались та укладались у вакуумні термозсідальні пакети з високими бар'єрними властивостями торговельної марки «Кріовак» (серій BB, TBG), після цього направлялись на вакуумування й термозсідання. Процес вакуумування проводили на напівавто- 
матичній вакуум-пакувальній машині «Webomatic CD-120». Процес термозсідання здійснювали на термозсідальному танку «ST-02» шляхом занурення завакуумованої упаковки 3 продуктом у гарячу воду. Температура води складала від 85 до $88^{\circ} \mathrm{C}$, час занурення $1,5-2$ секунди (згідно рекомендацій виробника пакетів). Час між обробкою м'яса та вакуумуванням складав не більше 15 хвилин, між вакуумуванням та термозсіданням - не більше 5 хвилин. Поверхню запакованого продукту підсушували серветками, після чого його направляли в холодильник для подальшого охолодження і зберігання за температури від 0 до $4^{\circ} \mathrm{C}$. Пакувальний матеріал повинен бути щільно прилеглим до поверхні м’яса чи напівфабрикату, без порожнеч повітря. 3 метою автоматизації виробництва та зменшення часу між операціями доцільно використовувати вакуум-пакувальні машини та термозсідальні тунелі конвеєрного типу. Дуже важливим фактором $\epsilon$ чітке дотримання температури продукту, що піддається пакуванню 3 подальшим проведенням термозсідання: чим нижча температура продукту, тим більше кінцевий термін ії зберігання. Бажано мати температуру продукту наближеною до $0^{\circ} \mathrm{C}$. Не дозволяється використовувати м'ясо 3 температурою в середині м'язів вище $4^{\circ} \mathrm{C}$, оскільки це призводить до коагуляції білка на поверхні продукту в процесі проведення термозсідання та негативно впливає на органолептичні показники в термінах зберігання.

Характеристики продукту вивчались за органолептичними та мікробіологічними показниками після закінчення технологічного процесу (фонові значення), на 20, 23, 27, 30 та 35 добу зберігання.

Результати досліджень. За результатами органолептичних і мікробіологічних досліджень максимальний позитивний результат для м'яса без кісток було отримано на 35-у добу зберігання, а для м'яса 3 кісткою - на 27-у добу зберігання. Фонові значення мікробіологічних досліджень (після закінчення технологічного процесу) наведені в табл. 1.

Результати мікробіологічних досліджень наприкінці термінів їх зберігання наведені в табл. 2 (для м'яса без кісток) та в табл. 3 (для м'яса 3 кісткою).

Таблиия 1. Фонові значення мікрофлори дослідних зразків

\begin{tabular}{|c|c|c|}
\hline Назва показника & $\begin{array}{c}\text { Результати } \\
\text { досліджень фону }\end{array}$ & Метод контролю, згідно 3: \\
\hline $\begin{array}{c}\text { Кількість мезофільних аеробних і факульта- } \\
\text { тивно-анаеробних мікроорганізмів (МАФАМ), } \\
\text { КУО в 1 г продукту, не більше ніж: }\end{array}$ & $4 \times 100$ & ГОСТ 10444.15 \\
\hline $\begin{array}{c}\text { Бактерії групи кишкових паличок (БГКП): } \\
\text { в 0,001 г продукту (для безкісткових) }\end{array}$ & Не виявлено & ГОСТ 21237 \\
\hline L. Mопосуtogenes, в 25 г продукту & Не виявлено & $\begin{array}{c}\text { ДСТУ ISO 11290-1 або } \\
\text { ДСТУ ISO 11290-2 }\end{array}$ \\
\hline $\begin{array}{c}\text { Патогенні мікроорганізми, зокрема бактерії } \\
\text { роду Salmonella, в 25 г продукту }\end{array}$ & Не виявлено & $\begin{array}{c}\text { ГОСТ 21237, ДСТУ ЕN } \\
12824\end{array}$ \\
\hline
\end{tabular}

Таблиця 2. Прикінцеві значення мікрофлори дослідних зразків (27-а доба)

\begin{tabular}{|c|c|c|}
\hline Назва показника & $\begin{array}{c}\text { Результати } \\
\text { досліджень на } \\
27-\text { добу зберігання }\end{array}$ & $\begin{array}{c}\text { Метод контролю } \\
\text { згідно з: }\end{array}$ \\
\hline 1 & 2 & 3 \\
\hline $\begin{array}{c}\text { Кількість мезофільних аеробних та факульта- } \\
\text { тивно-анаеробних мікроорганізмів (МАФАМ), } \\
\text { КУО в 1 г продукту, не більше ніж: }\end{array}$ & $3,1 \times 102$ & ГОСТ 10444.15 \\
\hline
\end{tabular}




\begin{tabular}{|c|c|c|}
\hline \multicolumn{1}{|c|}{ (1 } & 2 & 3 \\
\hline $\begin{array}{c}\text { Бактерії групи кишкових паличок (БГКП): } \\
\text { в 0,001 г продукту (для безкісткових) }\end{array}$ & Не виявлено & ГОСТ 21237 \\
\hline L. Monocytogenes, в 25 г продукту & Не виявлено & $\begin{array}{c}\text { ДСТУ ISO 11290-1 або } \\
\text { ДСТУ ISO 11290-2 }\end{array}$ \\
\hline $\begin{array}{c}\text { Патогенні мікроорганізми, зокрема бактерії } \\
\text { роду Salmonella, в 25 г продукту }\end{array}$ & Не виявлено & $\begin{array}{c}\text { ГОСТ 21237, } \\
\text { ДСТУ EN 12824 }\end{array}$ \\
\hline
\end{tabular}

Таблиия 3. Прикінцеві значення мікрофлори дослідних зразків (35-а доба)

\begin{tabular}{|c|c|c|}
\hline Назва показника & $\begin{array}{c}\text { Результат } \\
\text { дослідження на } \\
\text { 35-у добу зберігання }\end{array}$ & $\begin{array}{c}\text { Метод контролю } \\
\text { згідно з: }\end{array}$ \\
\hline $\begin{array}{c}\text { Кількість мезофільних аеробних і факульта- } \\
\text { тивно-анаеробних мікроорганізмів (МАФАМ), } \\
\text { КУО в 1 г продукту, не більше ніж: }\end{array}$ & $4,2 \times 102$ & ГОСТ 10444.15 \\
\hline $\begin{array}{c}\text { Бактерії групи кишкових паличок (БГКП): } \\
\text { в 0,0001 г продукту (для м'ясокісткових) }\end{array}$ & Не виявлено & ГОСТ 21237 \\
\hline L. Mопосуtogenes, в 25 г продукту & Не виявлено & $\begin{array}{c}\text { ДСТУ ISO 11290-1 або } \\
\text { ДСТУ ISO 11290-2 }\end{array}$ \\
\hline $\begin{array}{c}\text { Патогенні мікроорганізми, зокрема бактерії } \\
\text { роду Salmonella, в 25 г продукту }\end{array}$ & Не виявлено & $\begin{array}{c}\text { ГОСТ 21237 або } \\
\text { ДСТУ EN 12824 }\end{array}$ \\
\hline
\end{tabular}

Отримані результати, представлені в табл. 2 і 3, з урахуванням коефіцієнта запасу, дали змогу підтвердити та рекомендувати подовжені терміни зберігання охолодженого м'яса на напівфабрикатів 3 нього, що запаковані під вакуумом 3 подальшим проведенням термозсідання:

- для великошматкових - не більше 28 діб,

- для м'ясокісткових - не більше 21 доби.

Дані досліджень були враховані при розробленні зміни до нормативнотехнологічної документації на відповідну продукцію (ТУ У 15.1-31923621-0012003). Терміни придатності м'ясних напівфабрикатів з урахуванням такої зміни наведені в табл. № 4.

\section{Табличя 4. Нормативні значення щодо зберігання напівфабрикатів}

\begin{tabular}{|c|c|c|c|c|c|c|c|}
\hline \multirow{4}{*}{$\begin{array}{c}\text { Види } \\
\text { напівфабри- } \\
\text { катів, спосіб } \\
\text { розробки та } \\
\text { обробки }\end{array}$} & \multicolumn{7}{|c|}{ Термін придатності, діб, не більше } \\
\hline & \multicolumn{3}{|c|}{$\begin{array}{c}\text { в охолодженому стані від } 0^{\circ} \mathrm{C} \text { до } \\
4^{\circ} \mathrm{C} \\
\end{array}$} & \multicolumn{4}{|c|}{ в замороженому стані } \\
\hline & \multirow{2}{*}{$\begin{array}{c}\text { під } \\
\text { ваку- } \\
\text { умом }\end{array}$} & \multirow{2}{*}{$\begin{array}{c}\text { під } \\
\text { вакуумом з } \\
\text { наступним } \\
\text { проведен- } \\
\text { ням } \\
\text { термозсідан } \\
\text { ня }\end{array}$} & \multirow{2}{*}{$\begin{array}{c}\text { у } \\
\text { середовищі } \\
\text { захисного } \\
\text { газу }\end{array}$} & \multicolumn{2}{|c|}{\begin{tabular}{|c|} 
під вакуумом або під \\
вакуумом 3 \\
наступним \\
проведенням \\
термозсідання
\end{tabular}} & \multicolumn{2}{|c|}{$\begin{array}{c}\text { у середовищі } \\
\text { захисного газу }\end{array}$} \\
\hline & & & & $\begin{array}{c}\text { від мінус } \\
5^{\circ} \mathrm{C} \text { до } \\
\text { мінус } 10^{\circ} \mathrm{C}\end{array}$ & \begin{tabular}{|c|} 
від мінус \\
$15^{\circ} \mathrm{C}$ до \\
мінус \\
$18^{\circ} \mathrm{C}$ \\
\end{tabular} & \begin{tabular}{|c|} 
від мінус \\
$5^{\circ} \mathrm{C}$ до \\
мінус \\
$10^{\circ} \mathrm{C}$ \\
\end{tabular} & $\begin{array}{c}\text { від мінус } \\
15^{\circ} \mathrm{C} \text { до } \\
\text { мінус } 18^{\circ} \mathrm{C}\end{array}$ \\
\hline 1 & 2 & 3 & 4 & 5 & 6 & 7 & 8 \\
\hline \multicolumn{8}{|c|}{ Із яловичини, телятини, свинини та баранини натуральні: } \\
\hline $\begin{array}{c}\text { еликошматкові } \\
\text { порційні }\end{array}$ & $\begin{array}{l}14 \\
14\end{array}$ & 28 & $\begin{array}{l}10 \\
10\end{array}$ & $\begin{array}{l}60 \\
60\end{array}$ & $\begin{array}{l}180 \\
180\end{array}$ & $\overline{160}$ & $\overline{180}$ \\
\hline
\end{tabular}




\begin{tabular}{|c|c|c|c|c|c|c|c|}
\hline 1 & 2 & 3 & 4 & 5 & 6 & 7 & 8 \\
\hline дрібношматкові & 10 & - & 10 & 60 & 180 & 160 & 180 \\
м'ясокісткові & 10 & 21 & 10 & 30 & 120 & 45 & 120 \\
\hline \multicolumn{7}{|c|}{ Із яловичини, телятини, свинини та баранини, } \\
\multicolumn{7}{|c|}{ підготовлені до кулінарної обробки: } \\
\hline солені & 10 & - & 12 & 90 & 160 & 90 & 160 \\
в соусі & 12 & - & 15 & 90 & 160 & 90 & 160 \\
зі спеціями & 6 & - & 8 & 60 & 120 & 60 & 120 \\
\hline \multicolumn{7}{|c|}{ Із яловичини, телятини, } \\
фарши м'ясні, & - & - & 10 & 120 & 180 & 120 & 180 \\
\hline
\end{tabular}

Висновки. Дослідженнями обгрунтовані раціональні терміни зберігання охолодженого м'яса та напівфабрикатів 3 нього $з$ використанням сучасних пакувальних матеріалів.

При чіткому вхідному контролю сировини, дотриманні санітарно-гігієнічних вимог, температурних режимів на стадіях підготовки сировини, виробництва, пакування, транспортування і реалізації охолодженого м'яса та напівфабрикатів з нього обгрунтовані терміни зберігання дадуть можливість якісно організовувати логістику при зберіганні й доставці продукції споживачам.

\section{ЛІТЕРАТУР А}

1. Пасічний В.М. Використання модифікованого газового середовища та вакуумування при пакуванні і зберіганні охолодженого м'яса та напівфабрикатів з нього / В.М. Пасічний, О.В. Храпачов, А.І. Маринін // Науковий вісник ЛНУВМБТ імені С.З. Гжицького. 2016. - T. 18, № 2(68). — С. 68-72.

2. Михальченко Я. Как ты мясо упакуешь, так оно и проживет (Обзор решений для упаковки) / Я. Михальченко // Мясной бизнес. — 2011. — № 7. — С. $42-43$.

3. Лииневская И. «Охлажденка». Особенности упаковки / И. Лишневская // Мясные технологии. - 2007. - № 4. - С. 12-13.

4. Усатенко Н.Ф., Крижська Т.А. Зберігання та переробка продукції. Використання показника «активність води» в технології виробництва м'ясопродуктів / Н.Ф. Усатенко, Т.А. Крижська // Вісник аграрної науки. — 2012. — № 5. - С. $62-65$.

5. Шубина Г. Выделение влаги в упаковках готовых мясных продуктов: причины и пути решения проблемы / Г. Шубина // Мясной бизнес. - 2015. - № 2. С. $26-28$.

6. Пасічний В.M. Перспективні напрямки виробництва м'ясних та м'ясо- рослинних напівфабрикатів / В.М. Пасічний // Мясное Дело. — 2009. — № 8. — С. 15-19.

7. Пасічний В.М. Рангове оцінювання комбінованих м'ясопродуктів / В.М. Пасічний // Наукові праці Національного університету харчових технологій. - К. : УДУХТ, 2002. — Вип. № 11. - С. $77-80$.

8. Регулювання структурно-механічних показників низькокалорійних м'ясних січених напівфабрикатів з використанням нанокомпозитів / С.В. Іванов, В.М. Пасічний, І.М. Страшинський та ін. // Наукові праці Національного університету харчових технологій 2014. - Том 20, №. 6. - С. 227-233.

9. Ukrainets A., Pasichniy V., Zheludenko Yu., Zadkova S. (2016). Oleoresins effect on cooked poultry sausages microbiological stability. Ukrainian Food Journal, 5 (1), 124-134.

10. Ukrainets A.I. (2016). Antioxidant plant extracts in the meat processing industry. Biotechnologia Acta. 9 (2), 19-27. doi: 10.15407/biotech9.02.019. 


\title{
УПАКОВКА ПОД ВАКУУМОМ КАК СПОСОБ ПРОДЛЕНИЯ СРОКОВ ХРАНЕНИЯ ОХЛАЖДЕННОГО МЯСА И ПОЛУФАБРИКАТОВ ИЗ НЕГО
}

\author{
В.Н. Пасичный, О.В. Храпачев, А.И. Маринин, Р.С. Святненко
}

Национальный университет пищевых технологий

А.М. Гередчук

Полтавский университет экономики и торговли

Исследованиями обоснованы рациональные сроки хранения охлажденного мяса и полуфабрикатов из него с использованием современных упаковочных материалов. Результаты исследований позволили подтвердить и рекомендовать продленные сроки хранения охлажденного мяса и полуфабрикатов из него, которые упакованы под вакуумом с последующим проведением термоосаждения: для крупнокусковых - не более 28 суток, для мясокостных - не более 21 суток.

Определено, что упаковка охлажденного мяса под вакуумом целесообразна для крупнокусковых полуфабрикатов. Кроме того, хранение в модифицированной газовой среде лучше подходит для семейной или порционной упаковки, где важен привлекательный внешний вид и сохранение первичной фрормы и текстуры продукта, а также отсутствие заметного выделения влаги.

Ключевые слова: охлажденное мясо, вакуумирование, многослойные термоусадочные материалы, гарантированное качество, срок хранения. 
Удк 621.87

\title{
RESEARCH OF SCIENTIFIC RATIONAL CHARACTERISTICS FOR THE EXTRACTION OF POLYMERIC ARTICLES
}

\author{
M. Yakymchuk, L. Ivanova, V. Kostyuk, V. Yakymchuk \\ National University of Food Technologies
}

\begin{tabular}{|c|c|}
\hline Key words: & ABSTRACT \\
\hline $\begin{array}{l}\text { shredder, } \\
\text { grinding of polymer } \\
\text { material, } \\
\text { drive, } \\
\text { speed of rotation }\end{array}$ & $\begin{array}{l}\text { Every year around } 180 \text { million tons of polymers are produced } \\
\text { in the world. Of these, a large number of products are pro-duced - } \\
\text { from recycled packaging to specialized individual packaging. The } \\
\text { quality of the process of destruction of the polymer depends on its } \\
\text { nature, the external processing environment and the kinematic and }\end{array}$ \\
\hline $\begin{array}{l}\quad \text { Article history: } \\
\text { Received 21.02.2018 } \\
\text { Received in revised form } \\
\text { 09.04.2018 } \\
\text { Accepted } 29.05 .2018\end{array}$ & $\begin{array}{l}\text { geometric characteristics of the cutting tools. One of the first pro- } \\
\text { cessing operations of recycling polymer products is grinding. Pro- } \\
\text { spective equipment for the processing of polymers is «shredders». } \\
\text { The article presents the results of investigations of the cha- } \\
\text { racteristics of the work of a single-rotor shredder for secondary }\end{array}$ \\
\hline $\begin{array}{l}\text { Corresponding author: } \\
\text { mykolaiakymchuk. } \\
\text { 2016@gmail.com }\end{array}$ & $\begin{array}{l}\text { crushing of polymer products at different operating modes, a } \\
\text { method for determining the rational parameters of the elements } \\
\text { of the design of its drive. On the basis of the analysis of the } \\
\text { results of analytical and experimental studies, graphical depen- } \\
\text { dences of the shredder power change on time were obtained. It } \\
\text { is established that the average power difference of a shredder } \\
\text { drive at rotation of a shaft in the range from } 18 \text { to } 27 \text { rpm makes } \\
\text { up } 35 \% \text { in favor of smaller revolutions. To determine the } \\
\text { identity of the shredder's work, an experimental installation was } \\
\text { developed and manufactured. The recording device for techno- } \\
\text { logical and kinematic indices during the study was a personal } \\
\text { computer, and the instant indicators of the corresponding cha- } \\
\text { racteristics with the help of the developed program were obtained } \\
\text { in the form of charts. To analyze the adequacy of the mathe- } \\
\text { matical model of shredding products from polymers to real } \\
\text { processes, a full-featured experiment was conducted. The results } \\
\text { of the research received a mathematical-statistical equation for } \\
\text { determining the power of a shredder drive. The results can be } \\
\text { recommended for use when designing new shredder samples. }\end{array}$ \\
\hline
\end{tabular}

\section{ДОСЛІДЖЕННЯ РАЦІОНАЛЬНИХ ХАРАКТЕРИСТИК ШРЕДЕРА ДЛЯ ПОДРІБНЕННЯ ПОЛІМЕРНИХ ВИРОБІВ}

\author{
М.В. Якимчук, д-р техн. наук \\ В.С. Костюк, кан. техн. наук \\ Л.І. Іванова \\ В.М. Якимчук \\ Національний університет харчових технологій
}

У статті наведено результати досліджень характеристик роботи однороторного шредера для вторинного подрібнення полімерних виробів при різних

(C) М.В. Якимчук, В.С. Костюк, Л.І. Іванова, В.М. Якимчук, 2018 
режимах експлуатації, а також методику визначення раціональних параметрів елементів конструкції його приводу. На основі отриманих аналітичних результатів досліджень розроблено та виготовлено модернізовану експериментальну установку шредера. Під час проведення експериментальних досліджень було встановлено вплив зовнішніх факторів на ефективність подрібнення та характеристику роботи електродвигуна. Визначено вплив товщини полімерного матеріалу та його густини на зміну потужності привода. Результати досліджень представлені у вигляді критеріального рівняння.

Ключеві слова: шредер, подрібнення полімерного матеріалу, привод, частота обертання.

Постановка проблеми. Процес подрібнення полімерних матеріалів передбачає етап руйнування часток зовнішньою силою та етап подальшої агрегації цих часток. Якість процесу руйнування полімеру залежать від його природи, зовнішнього середовища переробки та кінематичних і геометричних характеристик ріжучих інструментів.

Дослідження умов, при яких руйнування полімерного матеріалу набуває мінімального значення потужності, має велику практичну цінність, тому що допомагає на етапі проектування подрібнювального пристрою вибрати найбільш раціональний спосіб подрібнення виробів з полімерних матеріалів і проводити механічні перетворення з найменшими витратами енергії.

Однією 3 перших технологічних операцій вторинної переробки виробів 3 полімерів є подрібнення. Конструкція подрібнювальних пристроїв залежить від типу полімерного матеріалу.

Так щокові дробарки передбачають подрібнення за допомогою сталевих рифлених плит шляхом роздавлювання; молоткові дробарки ударного типу роздрібнюють полімерні відходи за допомогою ударних молотків, закріплених шарнірно на роторі; конусні дробарки мають два сталеві конуси, між якими виріб з полімерного матеріалу стирається та роздавлюється.

Найпоширенішим видом подрібнювачів $\epsilon$ роторна дробарка. Одним 3 перспективним напрямків розвитку роторних дробарок $\epsilon$ шредери. Аналіз вітчизняних і зарубіжних конструкцій шредерів показав, що такі пристрої $є$ малодослідженим обладнанням щодо оптимізації ефективності подрібнення та зменшення енерговитрат.

Метою дослідження є удосконалення конструкції шредера шляхом підвищення ефективності процесу подрібнення та зменшення енерговитрат.

Викладення основних результатів дослідження. Для опису математичної моделі подрібнення полімерів за допомогою шредера використаний математичний апарат [1], який дає змогу отримати математичні залежності у вигляді матричних моделей [2]. У таких моделях процес подрібнення та руйнування виробів 3 полімерних матеріалів описується 3 певною ймовірністю отриманих частинок у вигляді кусків крупності всіх класів (рис. 1). Продукти руйнування при цьому характеризуються класом точності та можуть потрапляти у вихідний (заданий) отвір або продовжувати дрібнитися [3; 4].

Модель подрібнення представлена у вигляді диференціальних рівнянь (рис. 1) та встановлює залежність між $C$ - головною характеристикою подрібнення (залишком на контрольному ситі / часткою недомолоту матеріалу) та параметрами процесу ( $Q$ - ваговою витратою, $V$ - ваговим завантаженням, $U$ - лінійною 
швидкістю руху матеріалу, DL — коефіцієнтом зворотного перемішування, $n$ числом осередків, $x$ - лінійної координатою, $L$ - довжиною різальної частини).

\begin{tabular}{|c|c|c|}
\hline Вид моделі & Структурна схема моделі & Рівняняя структури потока моделі \\
\hline $\begin{array}{l}\text { Iдеапне } \\
\text { змшіуваняя }\end{array}$ & $\stackrel{\mathrm{QC}_{\mathrm{Ex}}}{\longrightarrow} \stackrel{\mathrm{Q}}{\mathrm{V}} \stackrel{\mathrm{QC}_{\mathrm{BBX}}}{\longrightarrow}$ & $\frac{\mathrm{dC}}{\mathrm{dt}}=\frac{\mathrm{Q}}{\mathrm{V}}\left(\mathrm{C}_{\mathrm{Ex}}-\mathrm{C}\right)$ \\
\hline $\begin{array}{l}\text { Ідеапне } \\
\text { витіснення }\end{array}$ & 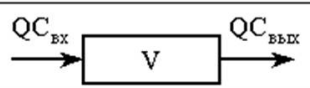 & $\frac{\partial \mathrm{C}}{\partial \mathrm{t}}=-\mathrm{U} \frac{\partial \mathrm{C}}{\partial \mathrm{x}}$ \\
\hline Дифузійна & $\stackrel{\mathrm{QC}_{\mathrm{Bx}}}{\longrightarrow} \stackrel{\mathrm{QC}}{\longrightarrow}$ & $\frac{\partial \mathrm{C}}{\partial \mathrm{t}}=\mathrm{D}_{\mathrm{L}} \frac{\partial^{2} \mathrm{C}}{\partial \mathrm{X}^{2}}-\mathrm{U} \frac{\partial \mathrm{C}}{\partial \mathrm{x}}$ \\
\hline Коміркова & \begin{tabular}{l|lll}
$\mathrm{QC}_{\mathrm{BX}}$ & $\mathrm{QC}_{\mathrm{BbX}}$ \\
$\rightarrow$ & $\mathrm{i}$ & $\mathrm{n}$ & $\mathrm{n}$
\end{tabular} & $\frac{1}{\mathrm{n}} \frac{\mathrm{dC}_{\mathrm{i}}}{\mathrm{dt}}=\frac{\mathrm{Q}}{\mathrm{v}}\left(\mathrm{C}_{\mathrm{i}-1}-\mathrm{C}_{\mathrm{i}}\right)$ \\
\hline
\end{tabular}

Рис. 1. Результуючі рівняння потоку матеріалу в подрібнювачі

Поряд 3 цим було досліджено вплив зміни частоти обертання валу шредера, товщини стінок та густини виробу 3 полімерного матеріалу на потужність електродвигуна (рис. 2).

Слід зазначити, що запропонована модель процесу подрібнення шредером виробів $з$ полімерного матеріалу має неповний опис процесу. Складність опису такого процесу полягає у визначенні значної кількості ідентифікаційних параметрів i, як наслідок, у необхідності додаткових експериментальних досліджень.

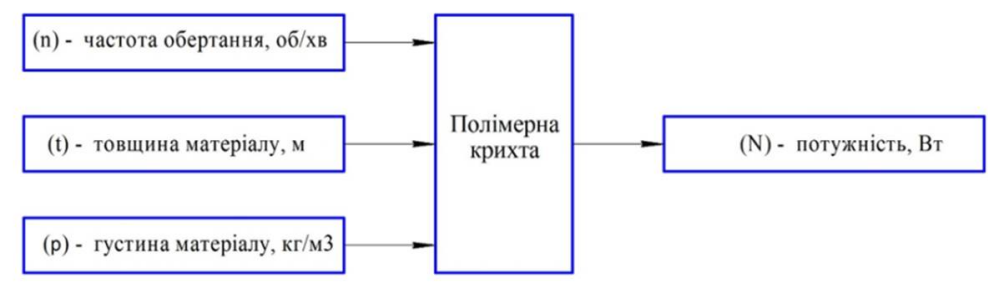

Рис. 2. Графічна модель досліджуваного процесу

Для визначення ідентифікаційних параметрів роботи шредера була розроблена i виготовлена експериментальна установка, схема і загальний вигляд якої представлена на рис. 3. Експериментальна установки складається з 1 - шредера; 2 - рами; 3 - муфти; 4 - черв'ячного редуктора; 5 - пасової передачі; 6 - натяжного пристрою; 7 - асинхронного електродвигуна; елементів управління і захисту.

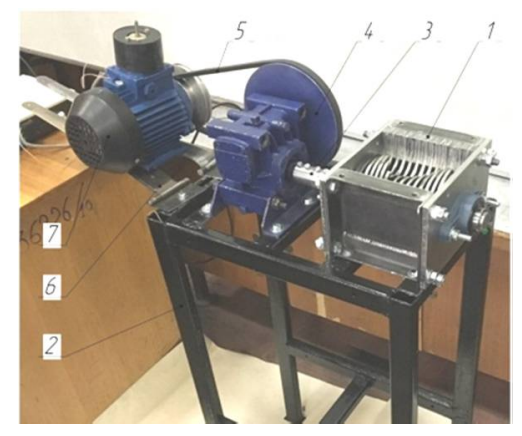

Рис. 3. Експериментальна установка шредера 
Експериментальна установки складається 31 - шредера; 2 - рами; 3 муфти; 4 - черв'ячного редуктора; 5 - пасової передачі; 6 - натяжного пристрою; 7 - асинхронного електродвигуна; елементів управління і захисту.

Вимірювальна частина установки складається 3 блоку керування «А2», блоку живлення $24 \mathrm{~V}$, аналогово-цифрового перетворювача, персонального комп’ютера. Об'єкт, що досліджувався - шредер (рис. 4). Конструкція шредера складається 3: 1 - валу з ножами; 2 - блоку контр-ножів; 3, 4 - бічних стінок, що закріплюють контр-ножі; 5 - двох опорних плит; 6 - двох радіальних самоорієнтовних корпусних підшипників UCFL205.

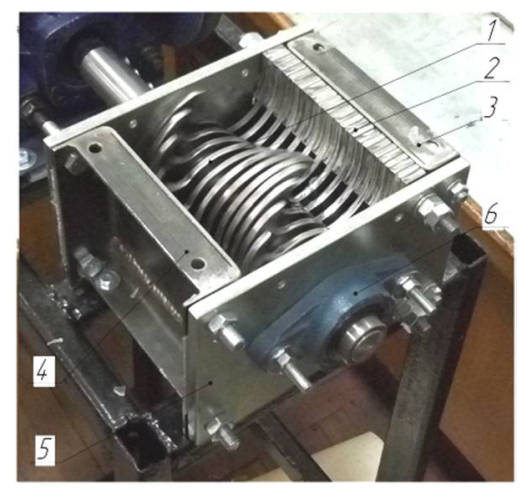

Рис. 4. Конструкція шредера

Реєструючим пристроєм технологічних і кінематичних показників під час дослідження був персональний комп'ютер, а миттєві показники відповідних характеристик за допомогою розробленої програми були отримані у вигляді графіків (рис. 5).

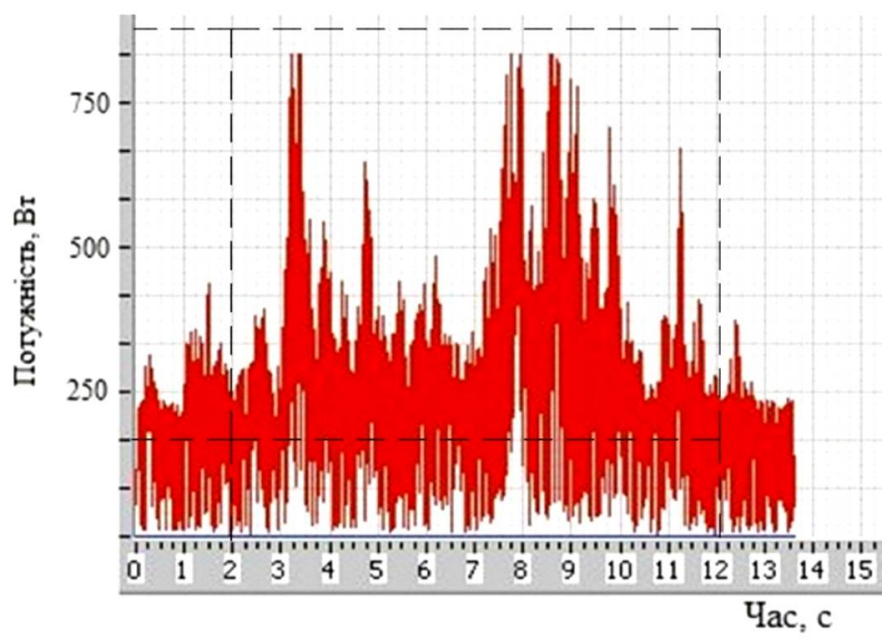

Рис. 5. Графік залежності зміни потужності електридвигуна привода шредера від часу при частоті обертання ротора 27 об/хв, товщині стінок виробу 3 полімерного матеріалу 1,5 мм та його густині $900 \mathrm{\kappa г} / \mathrm{m}^{3}$

Для роботи шредера під час проведення експериментів використовувались залишки упаковки з полімерних матеріалів, які є найбільш вживаними в паку- 
вальній галузі. Рівні зміни характеристик полімерних матеріалів використаних упаковок та обертів ротора шредера наведені в табл. 1.

Таблиия 1. Рівні зміни характеристик матеріалів

\begin{tabular}{|c|c|c|c|}
\hline & $\begin{array}{c}x_{1}(n)-\text { частота } \\
\text { обертання, об/хв }\end{array}$ & $\begin{array}{c}x_{2}(t)-\text { товщина } \\
\text { матеріалу, мм }\end{array}$ & $\begin{array}{c}x_{3}(\rho)-\text { густина } \\
\text { матеріалу, кг/ }{ }^{3}\end{array}$ \\
\hline 0-рівень & 23,125 & 0,95 & 1150 \\
\hline Крок варіювання $\Delta x$ & 4,625 & 0,55 & 250 \\
\hline Верхній рівень $(+1)$ & 27,75 & 1,5 & 1400 \\
\hline Нижній рівень $(-1)$ & 18,5 & 0,4 & 900 \\
\hline
\end{tabular}

Результати експериментальних досліджень було оброблено за допомогою програми «Grafula 3» (рис. 6).

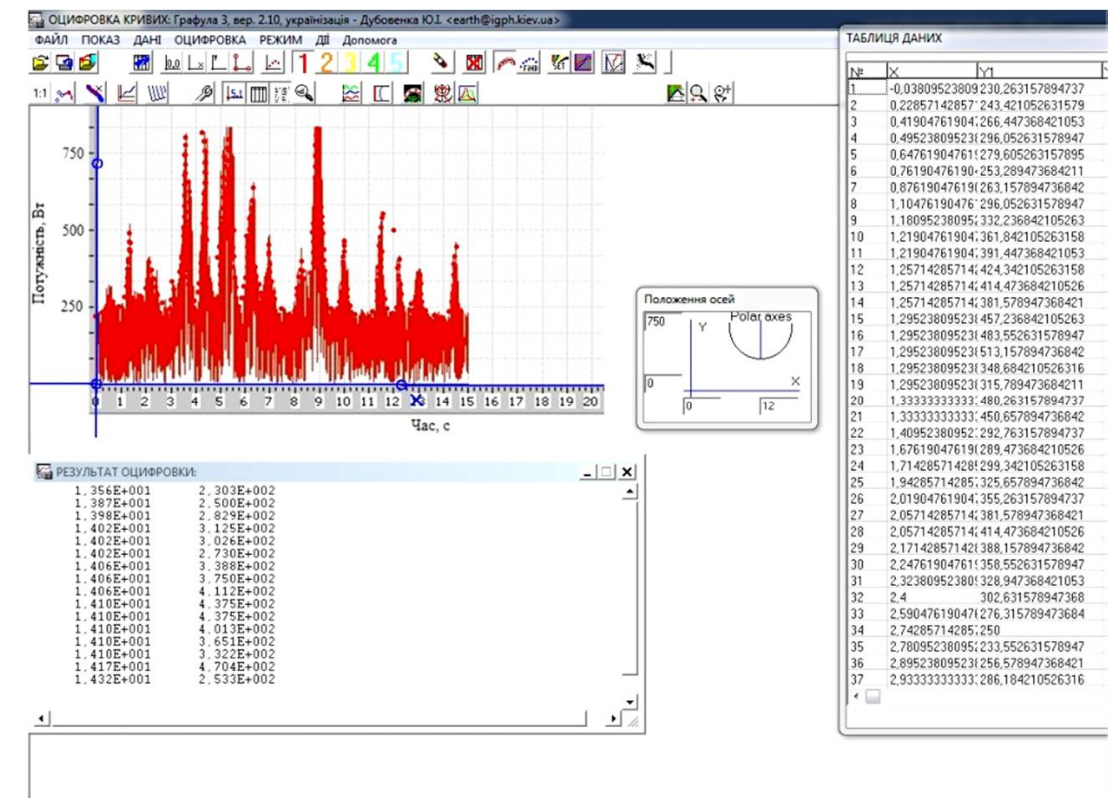

Рис. 6. Аналіз графіка зміни потужності електродвигуна привода шредера за допомогою програми «Grafula 3»

Результати експериментальних досліджень зміни потужності електродвигуна привода шредера від часу для різних полімерних матеріалів наведено на графіках (рис. 7).

Для аналізу адекватності отриманої математичної моделі подрібнення виробів з полімерів реальним процесам було проведено повнофакторний експеримент. За результатами досліджень отримано математично-статистичне рівняння для визначення потужності привода шредера:

$$
\begin{gathered}
\bar{N}=538,084+0,184 n-520,815 t-0,375 \rho+ \\
+18,261 n t+0,01018 n \rho+0,334 t \rho-0,0107 n t \rho .
\end{gathered}
$$

де $n$ - частота обертання ротора шредера, об/хв; $t$ - товщина полімерного

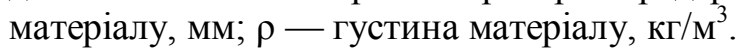




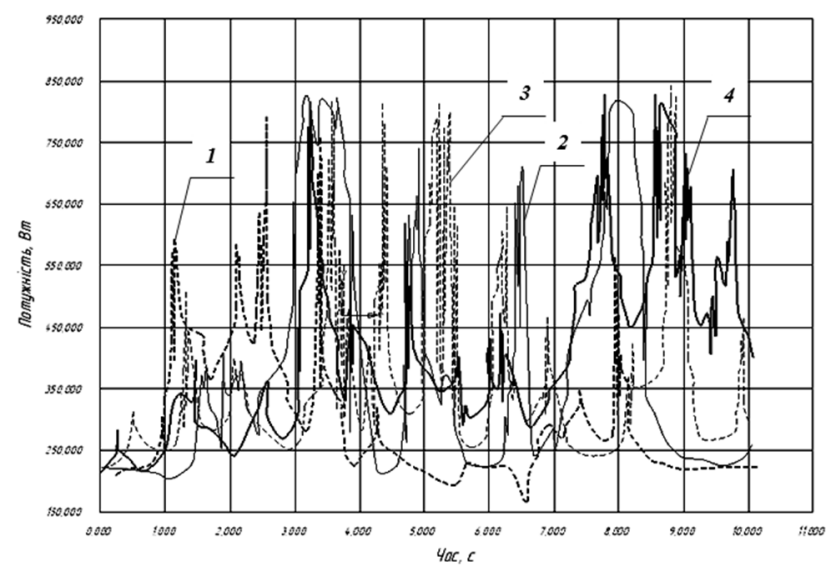

\section{Рис. 7. Графіки залежності потужності від часу для різних режимів роботи шредера при частоті обертання ротора 27 об/хв для рівнів зміни : \\ 1, 3 - товщині полімерного матеріалу; 2,4 - густині полімерного матеріалу}

Висновки. На основі аналізу результатів аналітичних та експериментальних досліджень було отримано графічні залежності зміни потужності привода шредера від часу. Встановлено, що середня різниця потужностей привода шредера при обертах валу ротора в межах від 18 до і 27 об/хв становить до 35\% на користь менших обертів.

Проведене статистичне опрацювання результатів аналітичних досліджень і розроблена математично-статистична модель процесу подрібнення виробів 3 полімерів дала змогу встановити залежність потужності привода від частоти обертів ротора, товщини та густини подрібнюваного полімеру.

Отримані результати можна рекомендувати для застосування під час проектування нових зразків шредерів.

\section{ЛІТЕРАТУРА}

1. Никитин А.Г. Сравнительный анализ энергозатрат дробилок, работающих на сжатие / А.Г. Никитин, Д.Ф. Сахаров. // Изв. вузов. Черная металлургия. - 2011. C. $56-57$.

2. Яблонский А.А. Курс теоретической механики: Учебник для вузов / А.А. Яблонский, А.Н. Никифорова. - Москва : Интеграл-Пресс, 2006. - 608 с.

3. Никитин А.Г. Влияние величины зазора между валком и неподвижной щекой одновалковой дробилки на фракционный состав готового продукта / А.Г. Никитин, Д.Ф. Сахаров // Тезисы докладов «Уголь России». - Новокузнецк, 2011. - С. 109-112.

4. Клушанцев Б.В. Валковые дробилки. Их параметры и метод расчета мощности / Б.В. Клушанцев // Строительные и дорожные машины. - 2002. — № 8. - С. 23-24.

5. Якимчук М.В. Дослідження характеристик подрібнення полімерних матеріалів шредером / М.В. Якимчук, І. Черпак, С. Скуйбіда // Програма і матеріали 83 міжнародної наукової конференції молодих учених, аспірантів і студентів «Наукові здобутки молоді вирішенню проблем харчування людства у XXI столітті», 5-6 квітня 2017 р. - К. : НУХТ, 2017 p. - Ч. 2. - 112 c.

6. Дослідження подрібнення ПЕТ пляшок методом різання з одночасним відокремленням горловини та днища / М. В.Якимчук, А. П. Беспалько, Г. Р. Валіулін, М. І. Юхно. // Харчова промисловість. - 2013. - № 14. - С. 119-124.

7. Патент України на корисну модель №116204, МПК В02С 4/30 (2006.01). Пристрій для подрібнення твердих матеріалів / М.В. Якимчук, Л.І. Іванова, І.Л. Черпак; заявник та 
патентовласник Національний університет харчових технологій. — № u201612134; заявл. 30.11.2016; опубл. 10.05.2017, бюл. № 9.

8. Якимчук М.B. Сортування полімерних пляшок із використанням елементів «технічного» зору/ М.В. Якимчук, О.М. Гавва, А.П. Беспалько, К.В. Пащенко// Упаковка. 2015. — № 2. - C. $48-52$.

\title{
ИССЛЕДОВАНИЕ РАЦИОНАЛЬНЫХ ХАРАКТЕРИСТИК ШРЕДЕРА ДЛЯ ИЗМЕЛЬЧЕНИЯ ПОЛИМЕРНЫХ ИЗДЕЛИЙ
}

\author{
Н.В. Якимчук, В.С. Костюк, Л.И. Иванова, В.Н. Якимчук \\ Национальний университет пищевых технологій
}

В статье приведены результаты исследований характеристик работы однороторного шредера для вторичного измельчения полимерных изделий при различных режимах эксплуатации, разработана методика определения рациональных параметров элементов конструкции его привода.

На основе полученных аналитических результатов исследований разработана и изготовлена модернизированная экспериментальная установка шредера. При проведении экспериментальных исследований было установлено влияние внешних фракторов на эффективность измельчения и характеристику работы электродвигателя. Определено влияние толщины полимерного материала и его плотности на изменение мощности привода. Результаты исследований представлены в виде критериального уравнения.

Ключевые слова: шредер, измельчения полимерного материала, привод, частота вращения. 
УДК 533.6.011, 621.694.2

\title{
ADVANTAGES IN THE CHOICE OF EJECTORS FOR PACKAGING EQUIPMENT
}

\section{Kryvoplias-Volodina}

National University of Food Technologies

\begin{tabular}{ll}
\hline \multicolumn{1}{c}{ Key words: } & \multicolumn{1}{c}{ ABSTRACT } \\
ejector, & \multicolumn{1}{c}{ Programs for simulation and computational resources based } \\
product, & on CFD-methods (Computational Fluid Dynamics) - is the basis \\
modes, & for solving complex technical problems. This is a method for \\
nozzle, & integrating advanced technologies into new technical solutions. \\
packing, & The paper describes the algorithm and the development on its \\
hydrodynamics, & basis of a mathematical model for the investigation of a \\
process & pneumatic nozzle system in packaging equipment. In ejector \\
\hline \multicolumn{1}{c}{ Article history: } & systems of packaging machines, performance is critical to the \\
Received 23.03.2018 & operation of the technology system. Construction of mathema- \\
Received in revised form & tical models is an effective method for analyzing the perfor- \\
Accepted 27.05.2018 & mance of the ejector. In some functional systems of packaging \\
\hline Corresponding author: & machines with nozzle devices it is necessary to take into \\
Kryvopliasvolodina & $\begin{array}{l}\text { account the performance as well. The urgent task for a simpli- } \\
\text { fied selection and verification of regulated technological opera- } \\
\text { tions with ejectors in packaging machines - requires the deve- } \\
\text { lopment of a generalized model. Different working envi- } \\
\text { ronments are considered in the calculations of the model: air, } \\
\text { vacuum, gas modified media. The results of a series of } \\
\text { simulation experiments revealed that the defining elements of } \\
\text { the ejector's performance are: a) a nozzle that provides the } \\
\text { required flow; b) the mixing chamber with the necessary para- } \\
\text { meters; c) the location of the nozzle and its form of commu- } \\
\text { nication with the surface of the ejector, providing the required } \\
\text { pressure distribution and turning the jet. The described techni- } \\
\text { que allows to synthesize new devices, accelerate the process of } \\
\text { research and development of technical documentation, shortens } \\
\text { the testing time. The overall goal of this article is to provide an } \\
\text { overview of the simulation methods of research in the Flow } \\
\text { Vision software package; to study the mathematical model of } \\
\text { the hydrodynamic nature in the pneumatic nozzle ejector for the } \\
\text { functional modules of the packaging equipment. }\end{array}$ \\
\hline
\end{tabular}

DOI: $10.24263 / 2225-2916-2018-23-17$

\section{ОБҐРУНТУВАННЯ ВИБОРУ ЕЖЕКТОРІВ ДЛЯ ПАКУВАЛЬНОГО ОБЛАДНАННЯ}

\author{
Л.О. Кривопляс-Володіна \\ Національний університет харчових технологій
}

Програми імітаційного моделювання й обчислювальні ресурси на базі CFD-меmoдів (Computational Fluid Dynamics) $є$ основою вирішення складних технічних 
завдань та інтегрування передових технологій в оновлені технічні рішення. У статті описано алгоритм і розроблені на його основі математичні моделі для дослідження пневмосоплових систем у пакувальному обладнанні. Представлена методика дає змогу синтезувати нові пристрої, прискорити процес дослідження і розробки технічної документації, скорочує час випробовувань. Загальна мета цієї статmі - дати огляд імітаційних методів дослідження в програмному пакеті (ПП) FlowVision; дослідити математичну модель гідродинамічного характеру в пневмосопловому ежекторі для фрункціональних модулів пакувального обладнання харчових продуктів.

Ключові слова: ежектор, продукт, режими, сопло, пакування, гідродинаміка, процес.

Постановка проблеми. У пакувальних лініях для харчових продуктів у допоміжних технологічних операціях широко застосовуються пневмосоплові пристрої із системами ежекторів. Прикладами застосування є операції оброблення поверхонь пакувальних матеріалів і споживчої упаковки, введення газомодифікованого середовища (ГМС) всередину упаковки, розділення потоку споживчих упаковок на конвеєрі, створення вакууму, очищення клапанів картонної упаковки перед нанесенням клейового розчину тощо. Для вибору раціональної конструкції ежектора, враховуючи різні фізико-механічні властивості харчових продуктів, необхідно мати можливість моделювання кінематичних і динамічних характеристик робочої речовини в процесі ежекції [1-3]. Вирішуючи актуальне завдання спрощеного вибору і перевірки регламентованих технологічних операцій 3 ежекторами в пакувальних машинах, доцільним $є$ розроблення узагальненої моделі для різних робочих середовищ (повітря, вакуум, ГМС).

Мета дослідження обгрунтована необхідністю доповнення методології основ проведення CFD-розрахунків для їх систематичного застосування при синтезі функіональних модулей пакувальних машин на основі пневмосоплових систем. В ежекторних системах пакувальних машин продуктивність має вирішальне значення для роботоздатності технологічної системи. Побудова математичних моделей $є$ ефективним методом аналізу продуктивності ежектора, а також окремих функціональних систем пакувальних машин із сопловими пристроями. Розроблені моделі можуть використовуватися для аналізу управління роботою пакувальної машини, інтерпретації експериментальних результатів і сприяння в проектуванні й оптимізації пакувальних ліній. Дослідні моделі були розділені на дві основні категорії: 1 - стійкі термодинамічні моделі, які можна далі поділити на однофазну модель потоку і модель двофазного потоку; 2 - динамічні моделі, які також поділяються відповідно з фазами [6].

Викладення основних результатів дослідження. Матеріалами дослідження $\epsilon$ ежектори з $L$-подібною компоновкою, із сопловим перерізом у межах 0,5 ; 0,7; 1; 2 мм. Методами дослідження є чисельні методи у складі CFD моделі ежектоpa. Найбільш розповсюджена в пакувальних машинах $є$ геометрія L-подібного ежектора. Принципова схема дослідного L-подібного ежектора приведена на рис. 1.

Ежектор складається 3 активного сопла 1 , яке подає в робоче середовище до приймальної камери 2 (для підведення потоку ежекції), пасивного сопла 3 для підведення повітря, камери змішування 4, дифузора 5, призначеного для підвищення статичного тиску. В деяких компоновках дифузор або пасивне сопло можуть бути відсутні [5; 6]. Перерізи $1-4$ є основними зонами дослідження тиску $p$, температури $T$, швидкості потоку $\omega$, масових витрат $G, \sigma$ коефіцієнтів відновлення тиску. 

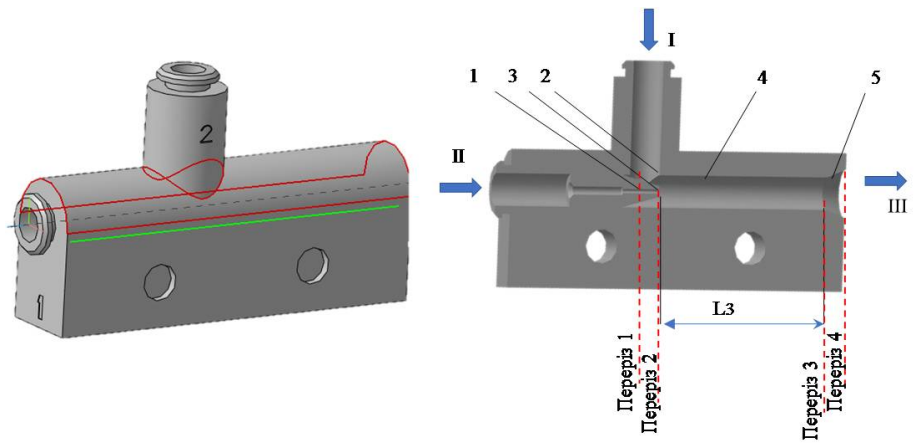

Рис. 1. Загальний вид конструкції L-подібних ежекторів соплових систем у пакувальних лініях: 3D розроблена модель із змінними прохідними перерізами; I — канал підведення робочого середовища в сопловий переріз; II — вхідний напірний канал; III - вивідний (вихлопний) канал

Завданням проведеного дослідження $є$ визначення раціональних значень параметрів системи обдуву і витратних характеристик стисненого повітря (робочого середовища). Під час вирішення поставлених завдань, використовувався аналіз і узагальнення літературних джерел [6; 8]. Розроблено алгоритм створення CFD моделі ежектора i проведено порівняльний аналіз із теоретичними дослідженнями ежекторів. Процес побудови чисельного рішення розділено на кілька кроків. На першому кроці сформовані диференціальні рівняння в часткових похідних, які описують безперервний процес, а також допоміжні (граничні і початкові) умови (які перетворюються в дискретну систему алгебраїчних рівнянь). Цей крок $є$ дискретизацією. Сьогодні найбільш ефективні методи дискретизації такі: метод кінцевих різниць (МКР); метод скінченних елементів (MCE); метод контрольних об'ємів (МКО). На виході дифузору статичний тиск газу $p_{4}$ більше статичного тиску в кінці камери змішування $p_{3}$. Якщо позначити масові витрати робочого потоку $G_{1}$, а масові витрати газу ежекції $G_{2}$, то співвідношення $n=G_{2} / G_{1} \in$ коефіцієнтом ежекції. При цьому відношення статичного тиску робочого газу перед соплом до статичного тиску газу ежекції $p_{1} / p_{2}$ буде ступенем розширення. Відношення статичного тиску на виході 3 дифузора до статичного тиску газу ежекції $p_{4} / p_{2}$ визначає ступінь стиснення, або ступінь підвищення тиску. При моделюванні у просторі ПП FlowVision, основним геометричним параметром ежектора $\epsilon$ відношення площин вихідних соплових перетинів для робочого потоку і потоку ежекції:

$$
\alpha=\frac{F_{1}}{F_{2}}=\frac{F_{1}}{F_{3}-F_{1}},
$$

де $F_{1}, F_{2}$ - відповідно площа вихідних соплових перерізів для підведення робочого потоку і потоку ежекції; $F_{3}$ - площа перетину циліндричної камери змішування (переріз 3, рис. 1). Ежектор 3 великим значенням $\alpha$ вважається високо напірним, але має малий коефіцієнт ежекції. I навпаки, ежектор з малим $\alpha$ дає змогу отримати великий коефіцієнт ежекції, але характеризується малим напором. 
Другий геометричний параметр при імітаційному моделюванні ежектора відносна довжина камери змішування $L_{1} / d_{3}$ - також впливає на динамічні характеристики ежектора.

Третій геометричний параметр моделі ежектора - ступінь розширення дифузора $f=F_{4} / F_{3}$ - приймалась як відношення площі перерізу на виході 3 дифузора до площини на вході в нього.

Припущенням дослідної моделі FlowVision приймалось, що ежектор працює при заданому статичному тиску на виході 3 дифузора (наприклад, при виході в атмосферу або всередину споживчої упаковки із постійним тиском). Ступінь розширення дифузора $f$ розглядалась як параметр, який суттєво впливає на режими роботи ежектора. Для проведення моделювання розроблено чотири 3D моделі ежектора з різними характеристиками прохідного робочого сопла.

При моделюванні ежектора також прийняті допущення про одномірність потоку. Закон збереження маси має вигляд:

$$
G_{3}=G_{1}+G_{2}, \text { тоді } G_{3} / G_{1}=1+n .
$$

На основі закону збереження енергії можна записати:

$$
G_{3}\left(c_{3} T_{3}+\frac{w_{3}^{2}}{2}\right)=G_{1}\left(c_{1} T_{1}+\frac{w_{1}^{2}}{2}\right)+G_{2}\left(c_{2} T_{2}+\frac{w_{2}^{2}}{2}\right)+Q,
$$

де $Q$ - загальна кількість тепла, яке підводиться до повітря (газу) в секунду через стінку змішувальної камери.

При розрахунках лінійних ежекторів, приймається, що $Q=0$ і гази, які змішуються, однорідні і мають однакову теплоємкість. Допущення:

$$
(n+1) \frac{T_{3}^{*}}{T_{1}^{*}}=1+n \frac{T_{2}^{*}}{T_{1}^{*}} .
$$

Введені співвідношення $\Theta=\frac{T_{2}^{*}}{T_{1}^{*}}$ дали змогу отримати зручні формули для розрахунку:

$$
\begin{aligned}
\frac{T_{3}^{*}}{T_{1}^{*}} & =\frac{n \Theta+1}{n+1} ; \\
\frac{a_{k 3}}{a_{k 1}} & =\sqrt{\frac{n \Theta+1}{n+1}},
\end{aligned}
$$

Витрати повітря (газу) в будь-якому перетині сопла розрахувались за формулою:

$$
G=m \sigma_{1} \frac{p^{*} F q(\lambda)}{\sqrt{T^{*}}}
$$

де $m$ знаходиться за формулою і для повітря $m=0,0404 \mathrm{~m}^{-1} \cdot \mathrm{c} \cdot \mathrm{K}^{0,5} ; \sigma_{1}$ коефіцієнт відновлення тиску в активному соплі. 
Виразимо коефіцієнт ежекції через відношення витрат за допомогою залежності (7):

$$
n=\frac{G_{2}}{G_{1}}=\frac{\sigma_{2}}{\sigma_{1}} \frac{p_{n}^{*} q\left(\lambda_{2}\right) F_{2} \sqrt{T_{1}^{*}}}{p^{*} q\left(\lambda_{1}\right) F_{1} \sqrt{T_{2}^{*}}} .
$$

Після спрощення отримаємо:

$$
n=\frac{p_{2}^{*} q\left(\lambda_{2}\right)}{p_{1}^{*} q\left(\lambda_{1}\right) \alpha \sqrt{\Theta}}
$$

де $\sigma_{2}, \sigma_{1}$ коефіцієнти відновлення тиску відповідно в активному і пасивному соплі $p_{1}^{*}=p^{*} \sigma_{1}$ i $p_{2}^{*}=p_{n}^{*} \sigma_{2}$. Аналогічно вищенаведеній послідовності розрахунку отримані рівняння, які зв'язують параметри повітря (газу) в перетині 1 і 3 i коефіцієнта ежекції:

$$
\frac{p_{3}^{*} q\left(\lambda_{3}\right) F_{3} \sqrt{T_{1}^{*}}}{p_{1}^{*} q\left(\lambda_{1}\right) F_{1} \sqrt{T_{3}^{*}}}=n+1 .
$$

Наведені рівняння надають можливість визначити основні параметри в перетинах 1, 2, 3 при заданих геометричних параметрах і початкових параметрах потоку.

Для розрахунку дифузора використовують рівняння нерозривності у формі:

$$
\frac{p_{4}^{*} F_{4} q\left(\lambda_{4}\right)}{\sqrt{T_{4}^{*}}}=\frac{p_{3}^{*} F_{3} q\left(\lambda_{3}\right)}{\sqrt{T_{3}^{*}}} .
$$

Коефіцієнт відновлення тиску в дифузорі $\sigma_{1}$ визначено за формулою:

$$
\sigma_{1}=\frac{p_{4}^{*}}{p_{3}^{*}}=\frac{p_{4}}{p_{3}^{*} \pi\left(\lambda_{4}\right)} .
$$

За умові, що $T_{4}^{*}=T_{3}^{*}$, рівняння нерозривності має вигляд:

$$
q\left(\lambda_{4}\right)=\frac{F_{3} q\left(\lambda_{3}\right)}{F_{3} \sigma_{1}}
$$

Якщо задати статичний тиск на виході $p_{4}$ із дифузора, рівняння нерозривності складатиме:

$$
y\left(\lambda_{4}\right)=\frac{F_{3} q\left(\lambda_{3}\right)}{F_{4} \sigma_{1}} .
$$

Враховуючи формулу [1] для визначення повного тиску після змішування, матимемо узагальнене значення тиску:

$$
p_{3}^{*}=\frac{\alpha p_{1}^{*}+p_{2}^{*}}{1+\alpha} .
$$


Приймемо величину $\lambda_{1}, \lambda_{2}, \lambda_{3}$ у межах нормальних значень[8] - $(0,15-1,1)$ i відношення температур $0,3<\Theta<3,0$ для проведення імітаційного моделювання ежектора.

Результати CFD моделювання роботи L-подібного ежектора. На основі результатів імітаційного моделювання ПП FlowVision (рис. 2, табл. 1), проведено аналіз вищеописаної моделі ежектора. Вхідні параметри імітаційної моделі: робоче середовище - повітря $\left(\mathrm{N}_{2}+\mathrm{O}_{2}+\mathrm{Ar}+\mathrm{CO}_{2}\right)$, азот, кисень; робочий тиск на вхідному перерізі ежектора - 10 бар, температура навколишнього середовища 293К, тиск навколишнього середовища - 1,013 бар.

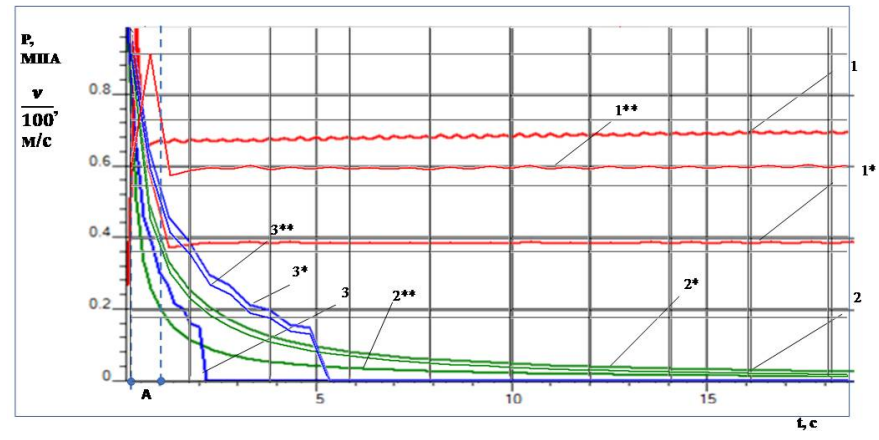

Рис. 2. Зміна робочих характеристик ежектора в сопловому перерізі:

1 - швидкість повітря ; 1 * - швидкість $\mathrm{N}_{2} ; 1$ ** - швидкість $\mathrm{O}_{2} ; 2$ - тиск повітря; 2 * - тиск

$\mathrm{N}_{2} ; 2 * *$ - тиск $\mathrm{O}_{2} ; 3$ - потенційна енергія (повітря); $3 *$ - потенційна енергія $\left(\mathrm{N}_{2}\right)$;

$3^{*}$ - потенційна енергія $\left(\mathrm{O}_{2}\right) ; \mathrm{A}$ - зона зміни характеристик робочого середовища при проходженні перерізу II

Таблиця 1. Результати імітаційного моделювання L-подібного ежектора

\begin{tabular}{|c|c|c|c|c|}
\hline 嵒点 & 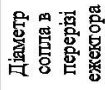 & Робоче середов ище & Характеристика зміни пвидкості (вомініï) & $\begin{array}{l}\text { Характеристики зміни тиску в } \\
\text { перерізі сошна ежектора в } \\
\text { запежності від витрат }\end{array}$ \\
\hline 1 & $\varnothing 0,7$ мм & 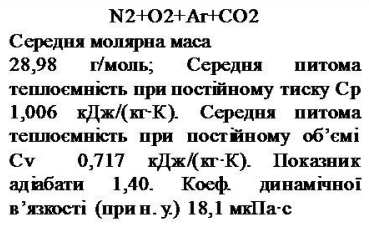 & & \\
\hline 2 & $\varnothing 0,7$ мм & 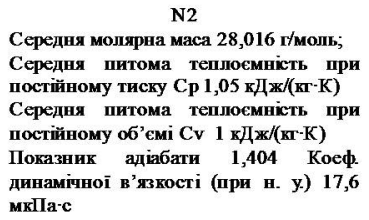 & & 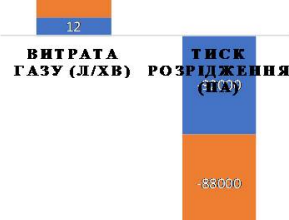 \\
\hline 3 & $\varnothing 0,7$ мм & 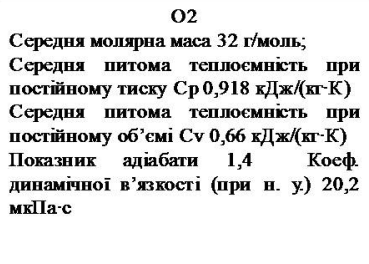 & & 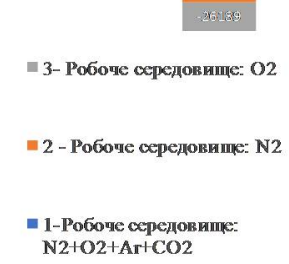 \\
\hline
\end{tabular}


Висновки. У результаті проведених досліджень розроблено алгоритм діагностики пневмосистеми із сопловими пристроями на основі ежекторів. Розроблено імітаційну модель та визначено характеристики розподілу тиску і швидкості руху робочого середовища всередині ежектора. Отримані результати доводять, що динамічні моделі мають більш високу точність прогнозування і дають більше інформації порівняно із стійкими термодинамічними моделями.

На підставі результатів проведеного циклу імітаційних експериментів можна вважати, що визначальними елементами робочої характеристики ежектора $є$ : а) сопло, що забезпечує потрібну течію; б) камера змішування з необхідними параметрами; в) місце розташування сопла і форма його сполучення 3 поверхнею ежектора, що забезпечують необхідний розподіл тиску і поворот струменя. Зазначені фактори визначають рівень витратної характеристики і ефективність роботи низьконапірної ежекторної системи в пакувальній машині.

\section{ЛITEРАТУРА}

1. Пажи Д.Г. Распылители жидкости / Д.Г. Пажи, В.С. Галустов. - М. : Химия, 1979. $-216 \mathrm{c}$.

2. A Guide to Improving the Performance of Your Drying and Blow-off Applications with WindJet. // Catalog.- U.S.A. : Air Products Publishing. - 2014. - 20 p.

3. Best Practice Guidelines for the Use of CFD in Nuclear Reactor Safety Applications. Nea/CSNI/R, (2007)5, 154 p.

4. Kryvoplyas-Volodina L. Research of dynamic process in the pneumatic cylinder system of double action at the stable movement/ Journal of food and packaging science technique and technologies. - 201. - Volum 2. - Year III, №4. - C. 138-142. $180 \mathrm{p}$.

5. Assessmet of CFD Codes for Nuclear Reactor Safety Problems. Nea/CSNI/R, (2007)13,

6. Extension of CFD Codes Application to Two-Phase Flow Safety Problems (Phase 2). Nea/CSNI/R, (2007)13.

7. Oberkampf W.L., Trucano T.G., Hirsch C. Verification, Validation and Predictive Capability in Computational Engineering and Physics. Applied Mechanics Reviews, vol. 57, 2004, pp. 345-384.

8. Computational fluid dynamics best practice guidelines for dry cask applications. Final report. NUREG-2152. U.S. NRC, 2013, 117 p.

\section{ОБОСНОВАНИЕ ВЫБОРА ЭЖЕКТОРОВ ДЛЯ УПАКОВОЧНОГО ОБОРУДОВАНИЯ}

\section{Л.О. Кривопляс-Володина \\ Национальний университет пищевых технологій}

Программы имитационного моделирования и вычислительные ресурсы на базе CFD-методов (Computational Fluid Dynamics) являются основой решения сложных технических задач и интегрирования передовых технологий в новые технические решения. В работе описан алгоритм и разработка на его основе математической модели для исследования пневмосопловой системы в упаковочном оборудовании. Представленная методика позволяет синтезировать новые устройства, ускорить процесс исследования и разработки технической документации, сокращает время испытаний. Общая цель этой статьи - дать обзор имитационных методов исследования в программном пакете (ПП) FlowVision; исследовать математическую модель гидродинамического характера в пневмосопловом эжекторе для функциональных модулей упаковочного оборудования.

Ключевые слова: эжектор, продукт, режимы, сопло, упаковки, гидродинамика, процесс. 


\title{
RESEARCH OF THE PNEUMATIC HOSE SHUTTER IN MECHATRONIC SYSTEMS OF THE DOSAGE OF LIQUID FOODSTUFFS
}

\author{
O. Gorchakova, M. lakymchuk \\ National University of Food Technologies
}

\begin{tabular}{|c|c|}
\hline \multirow{2}{*}{\begin{tabular}{l}
\multicolumn{1}{c}{ Key words: } \\
dosing system, \\
pneumatic hose shutter, \\
mechatronic module, \\
effective area
\end{tabular}} & \multirow{4}{*}{$\begin{array}{l}\text { ABSTRACT } \\
\text { The creation of a new packaging equipment for the packaging } \\
\text { of liquid products is universal at the changing the dose or } \\
\text { packaging material is the main task of the present days which has a } \\
\text { flexible structure. Its solution requires a systematic approach, } \\
\text { which is starting with the development of the concept of designing } \\
\text { dosing devices and finishing with the designs of actuators. Such a } \\
\text { concept of the present days may be the concept of using the } \\
\text { mechatronic principle of designing dosing equipment with using of } \\
\text { a pneumatic hose shutter. The authors proposed the using of } \\
\text { pneumatic hose gates in the structure of the mechatronic module } \\
\text { for solving this problem. These article presents the analysis of } \\
\text { constructions of hose gates and proposes the structural scheme of } \\
\text { the mechatronic module for the dispensing of liquid food products. } \\
\text { The paper presents a mathematical model of the calculation of the } \\
\text { effective area of the passage section of the pneumatic hose shutter. } \\
\text { The effective area of the passage section of the pneumatic hose } \\
\text { shutter from the change in the inlet pressure has been expe- } \\
\text { rimentally investigated. The check of received analytical results by } \\
\text { experimental researches is the advantage of the given material. } \\
\text { Experimental installation was designed and manufactured for this } \\
\text { purpose. The conducted experimental researches allowed to deter- } \\
\text { mination the dependence of the change in the effective area of the } \\
\text { cross-section of normally open and normally closed pneumatic } \\
\text { hose gates from the value of the input control pressure. It was } \\
\text { found that this dependence has a nonlinear characteristic and is } \\
\text { characterized by a small range of changing of the control pressure. } \\
\text { The obtained results may be further used in the design of new } \\
\text { dosage devices on the mechatronic modules for liquid foods. }\end{array}$} \\
\hline & \\
\hline $\begin{array}{l}\text { Received } 21.02 .2018 \\
\text { Received in revised form } \\
12.04 .2018 \\
\text { Accepted } 31.05 .2018\end{array}$ & \\
\hline & \\
\hline
\end{tabular}

\section{ДОСЛІДЖЕННЯ ПНЕВМАТИЧНИХ ШЛАНГОВИХ ЗАТВОРІВ У МЕХАТРОННИХ СИСТЕМАХ ДОЗУВАННЯ РІДКИХ ХАРЧОВИХ ПРОДУКТІВ}

\author{
О.М. Горчакова, аспірант \\ М.В. Якимчук, д-р техн. наук \\ Національний університет харчових технологій
}

Створення нового пакувального обладнання для фрасування рідких продуктів, яке має гнучку структуру та є універсальним при зміні дози чи матеріалу упа-

(C) О.М. Горчакова, М.В. Якимчук, 2018 
ковки, є важливим технічним завданням. Його вирішення потребує системного підходу, починаючи з розробки концепції проектування дозуючих пристроїв $i$ закінчуючи конструкціями виконавчих механізмів. Такою концепцією може бути використання мехатронного принципу проектування дозувального обладнання з використанням пневматичного шлангового затвору. У статmі наведено математичну модель розрахунку зміни ефективної площі прохідного перерізу пневматичного шлангового затвора. Експериментально досліджено цю площу залежно від зміни вхідного тиску. Отримані результати можливо в подальшому використовувати при проектуванні нових дозувальних пристроїв для рідин.

Ключові слова: система дозування, пневматичний шланговий затвор, мехатронний модуль, ефективна площа.

Постановка проблеми. Розвиток способів дозування рідкої харчової продукції безпосередньо пов'язаний з удосконаленням технології виробництва, підвищенням вимог до точності дозування, надійності та швидкодії дозаторів. Основними вимогами до нових зразків дозаторів є забезпечення як традиційних показників продуктивності, економічності (мінімальної вартості), надійності, так i технологічних показників: стабілізації миттєвих або середніх витрат при заданому їх значенні; зміна витрат за заданим законом (програмно) залежно від зміни параметрів технологічного процесу або об'єкта дозування.

На основі проведеного аналізу існуючих конструктивних схем обладнання для дозування рідкої продукції розроблено класифікацію пристроїв дозування та фасування рідкої продукції, яку наведено на рис. 1 [1].

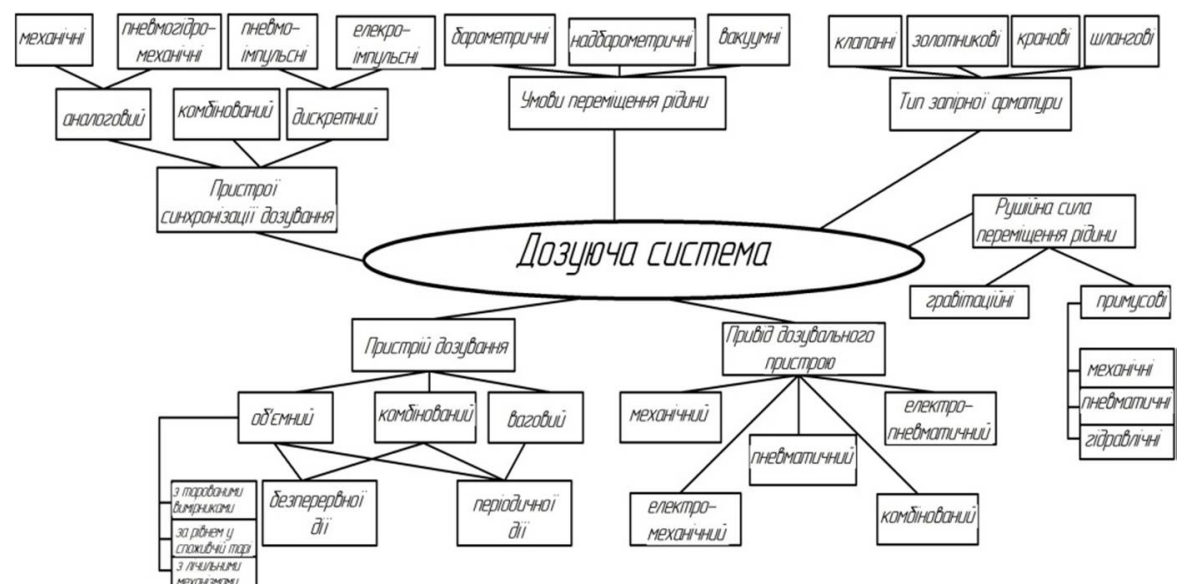

Рис. 1. Класифікація дозуючих систем

На основі аналізу встановлено, що для задоволення вимог виробників і споживачів, які виникають на споживчому ринку пакованої рідкої продукції, новітні дозатори повинні відповідати певній уніфікації, мати можливість швидкого переналагодження на різні величини дози залежно від зміни виду рідкої продукції та типу тари $[2 ; 3]$.

Одним із перспективних напрямів розробки конструкцій нових дозаторів, які відповідають вищезазначеним вимогам, $є$ використання пневматичних шлангових затворів. Характерною рисою керування шланговим затвором $\epsilon$ змінний переріз, який можна регулювати за допомогою зміни тиску повітря. 
На основі проведеного аналізу конструкцій шлангових затворів запропонована структурна схема мехатронного модуля для дозування рідких харчових продуктів (рис. 2).

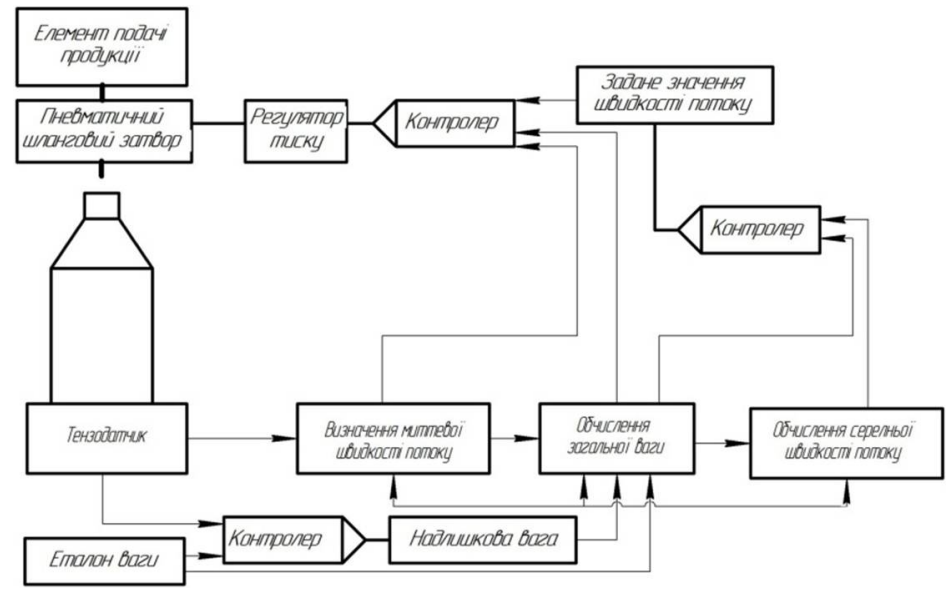

Рис. 2. Структурна схема мехатронного модуля для дозування рідких продуктів за допомогою пневматичного шлангового затвору

Процес наповнення упаковки рідкими харчовими продуктами в запропонованій структурній системі керування здійснює контролер, який аналізує миттєву та відносну швидкості потоку рідкої продукції та ії вагу [4; 5]. На базі отриманих даних контролер за допомогою регулятора тиску контролює площу прохідного перерізу пневматичного шлангового затвору, через який подається потік рідкого харчового продукту і за рахунок чого відбувається суттєве підвищення точності дозування.

Мета дослідження полягає в розробленні математичної моделі розрахунку зміни ефективної площі прохідного перерізу пневматичного шлангового затвора як функції зміни тиску керування в системі дозування рідин.

Матеріали і методи. Для виконання досліджень було проаналізовано конструкції пневматичних шлангових затворів (рис. 3) та встановлено, що існує два типи пневматичних шлангових затворів, а саме: нормально відкритий (рис. 3a) та нормально закритий (рис. 3б) [6; 7].

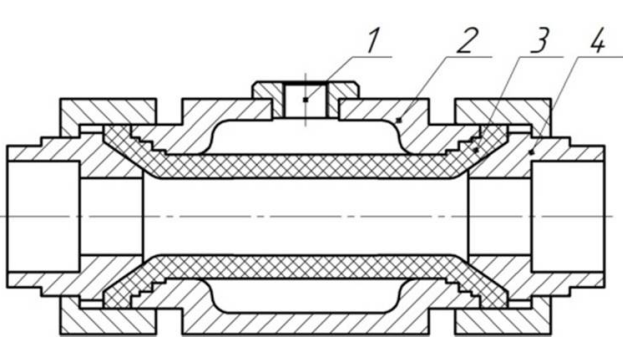

a)

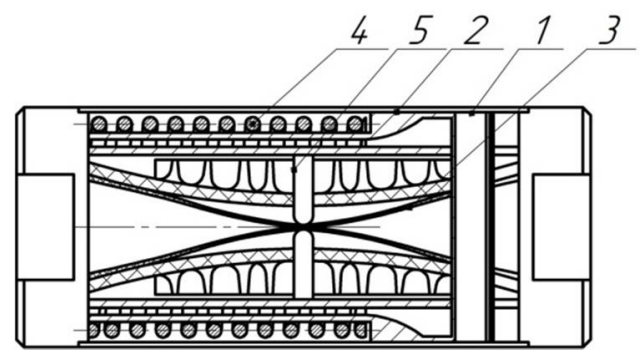

б)

Рис. 3. Конструкція пневматичного шлангового затвору: а) нормально відкритий:

1 - патрубок подачі стисненого повітря; 2 - корпус; 3 - патрубок з еластичного матеріалу; 4 - фланець; б) нормально закритий: 1 - патрубок подачі стисненого повітря; 2 - корпус; 3 - патрубок 3 еластичного матеріалу; 4 - пружина; 5 - поршень 
На першому етапі проектуванні мехатронного модуля для дозування рідких харчових продуктів було визначено залежності зміни ефективної площі перерізу прохідного патрубка шлангового затвору від тиску керування [8; 9].

Для розрахунку було розроблено розрахункову схему (рис. 4).

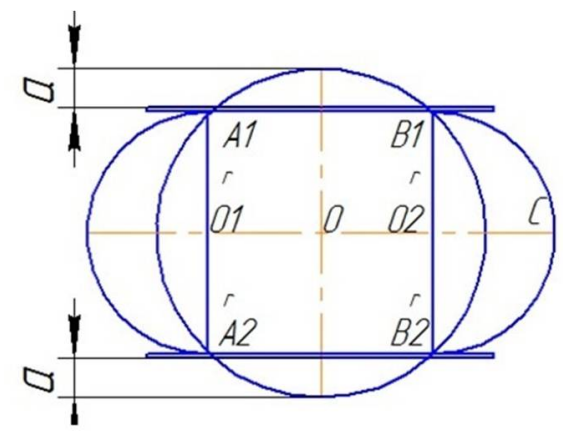

\section{Рис. 4. Розрахункова схема роботи шлангового затвору}

Якщо на затворі дозатора відсутнє стиснене повітря, то ефективна площа перерізу прохідного патрубка визначається за формулою:

$$
f_{0}=\pi R^{2}
$$

де $R$ - внутрішній радіус патрубка.

При подачі стисненого повітря відбувається зміна форми ефективної площі на величину $a$ від вихідного положення. Патрубок приймає форму, що складається з прямокутника $A_{1} A_{2} B_{2} B_{1}$ і двох півкіл з радіусом $r$.

Вважаючи, що периметр у середині патрубка в площині перетину не змінюється, то можна записати співвідношення:

$$
2 \pi R=2 A_{1} B_{1}+2 \pi r .
$$

3 рис. 4 видно, що $r=R-a$ і відрізок

$$
A_{1} B_{1}=\pi a
$$

Тоді площа перетину частково перетисненого патрубка визначається за формулою:

$$
f=4 A_{1} B_{1} r+\pi r^{2} .
$$

У результаті підстановки рівняння (3) та (4) в рівняння (2) було отримано величину зміни ефективної площі $f$ як функцію від величини переміщення $a$ :

$$
f(a)=\pi\left(R^{2}-a^{2}\right) .
$$

Змінювати площі прохідного перерізу затвора можливо регулюванням тиску в корпусі (рис. 3). При цьому прохідний переріз $f$ може встановлюватися за рівнянням (5). Витрата рідини $Q\left(\mathrm{м}^{3} /\right.$ год) через перетин затвора $f\left(\mathrm{~cm}^{2}\right)$ визначається як: 


$$
Q=5,04 \cdot f \cdot \zeta^{-0,5}(\Delta \mathrm{P} / \rho)^{1 / 2},
$$

де $\zeta$ - безрозмірний коефіцієнт опору; $\Delta \mathrm{P}$ - перепад тиску на перерізі $f$.

Для перевірки адекватності результатів аналітичних досліджень було розроблено експериментальну установку (рис. 5) [10]. Для виконання експериментальних досліджень було обрано нормально відкритий шланговий затвор компанії AKО та нормально закритий шланговий затвор компанії FESTO 3 внутрішніми діаметрами 15 мм кожний. Зміна тиску в затворі виконувалась за допомогою регулятора тиску VPPX 3 аналоговим вихідним сигналом компанії FESTO.

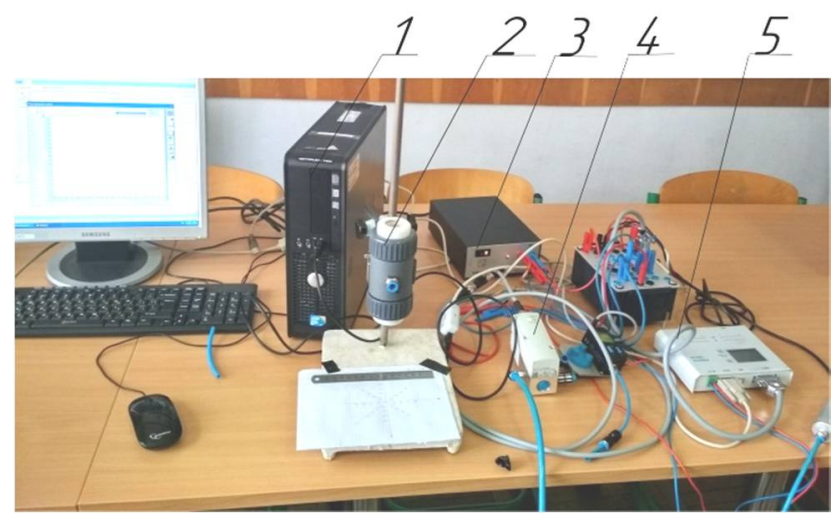

Рис. 5. Експериментальна установка для дослідження шлангових затворів:

1 - комп'ютер; 2 - нормально відкритий шланговий затвор (a); 2 - нормально закритий шланговий затвор (б); 3 - блок живлення; 4 - електронний датчик тиску;

$$
5 \text { - регулятора тиску VPPX }
$$

Результати досліджень нормально відкритого шлангового затвору наведені у вигляді графіків (рис. 6).

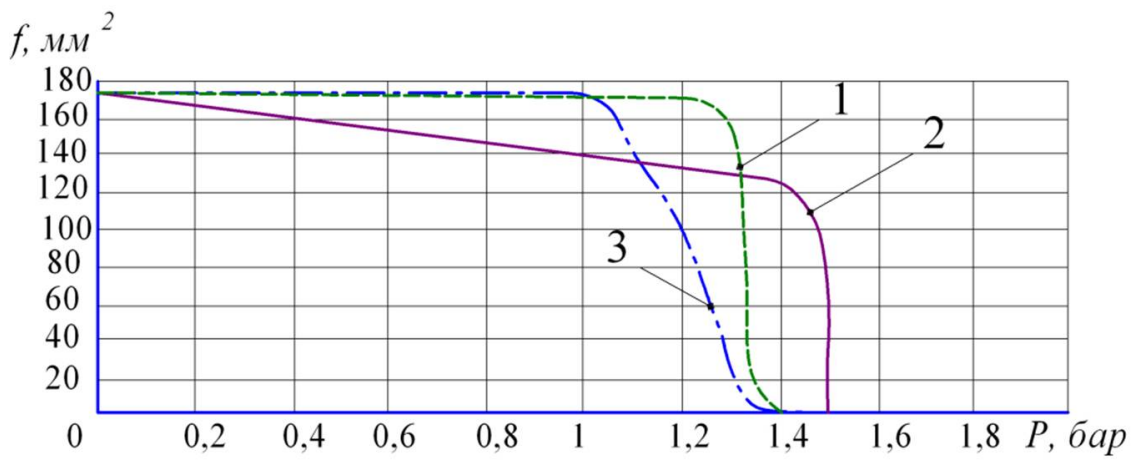

Рис. 6. Графік зміни ефективної площі

нормально відкритого шлангового затвору $(f)$ від вхідного керуючого тиску $(P)$ :

1 - аналітичні дослідження; 2 - закривання; 3 - відкривання

3 графіка 6 випливає, що на етапі закривання шлангового затвору (крива 2) ефективна площа перерізу змінюється лінійно до значення тиску $P=1,48$ бар, після чого відбувається їі різке зменшення за незначної зміни тиску, клапан 
закривається. На етапі відкривання шлангового затвору (крива 3) ефективна площа перерізу не змінюється до значення тиску $P=1$ бар, після чого відбувається плавне зменшення ефективної площі перерізу до тиску $P=1,36$ бар, клапан повільно відкривається.

Результати досліджень нормально закритого шлангового затвору наведені у вигляді графіків (рис. 7).

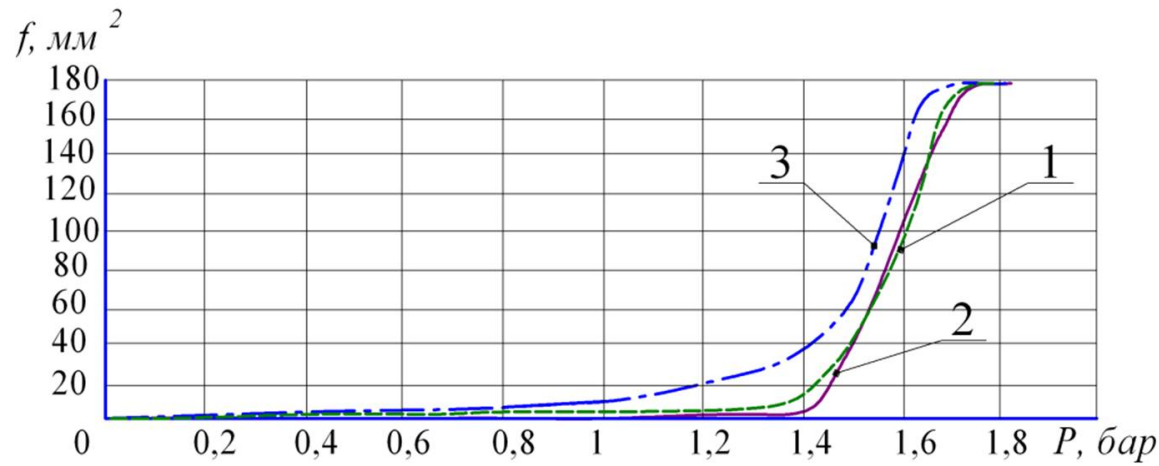

Рис. 7. Графік зміни ефективної площі

нормально закритого шлангового затвору $(f)$ від вхідного керуючого тиску $(P)$ :

1 - аналітичні дослідження; 2 - відкривання; 3 - закривання

У результаті обробки експериментальних досліджень нормально закритого шлангового затвору (рис. 7) було встановлено, що межі зміни ефективної площі під час відкривання (крива 2) затвору є значними. Однак на етапі закривання шлангового затвору (крива 3) ефективна площа перерізу різко зменшується за незначної зміни тиску до значення тиску $P=1,3$ бар, після чого процес закривання відбувається повільно.

Висновки. На основі проведених аналітичних та експериментальних досліджень роботи нормально відкритого та нормально закритого шлангових затворів було розроблено математичну модель розрахунку зміни їх ефективної площі прохідного перерізу від величини вхідного керуючого тиску та перевірено iï адекватність експериментальними дослідженнями. Встановлено, що залежності мають нелінійні характеристики та характеризуються малим діапазоном зміни керуючого тиску. Цей факт суттєво і негативно впливає на алгоритм роботи системи керування мехатронного модуля 3 пневматичним шланговим затвором та вибір їі елементів.

\section{ЛІТЕРАТУРА}

1. Пакувальне обладнання : підручник / О.М. Гавва, А.П. Беспалько, А.І. Волчко, O.О. Кохан. - К. : ІАЦ Упаковка, 2010. — 746 с.

2. Методологія проектування пакувальних машин на основі мехатронних модулів / О.М. Горчакова, М.В. Якимчук, А.В. Деренівська, А.П. Беспалько // Харчова промисловість. - 2016. - № 19. - С. 105-112.

3. Якимчук М.В. Шляхи та способи заощадження енергії в пневмоприводах пакувальних машин / М.В. Якимчук, О.М. Гавва, А.П. Беспалько, О.М. Горчакова // V Міжнародна спеціалізована всеукраїнська науково-практична конференція «Ресурсо- та енергоощадні технології виробництва і пакування харчової продукції - основні засади ії конкурентоздатності» (НУХТ, Київ, Україна, 14 вересня 2016 р.). — К. : НУХТ, 2016. — C. $18-20$. 
4. Якимчук М.В. Мехатроніка - шлях розвитку пакувальних машин IV та V поколінь/ М.В. Якимчук, О.М. Гавва // Упаковка. - 2015. — № 5. - С. $38-41$.

5. Якимчук М.В. Функціонально модульне проектування машин: моногр. / О.М. Гавва, М.В. Якимчук, Л.О. Кривопляс-Володіна [та ін.]. — К. : Видавництво «Сталь», 2015. - 547 с.

6. Каталог продукции АКО Corporation. Пневматические шланговые задвижки [Электронный ресурс]. - Дата доступу: 03.03.2018. — Режим доступу : https://www.perezhimnoj-klapan.ru/materialy-dlja-zagruzki.html.

7. Гуревич Д.Ф. Расчет и конструирование трубопроводной арматуры / Д.Ф. Гуревич. - Москва : ЛКИ, 2008. — 480 с.

8. Жавнер В.Л. Мехатронные принципы проектирования техноло-гического оборудования / В.Л. Жавнер, А. Б. Смирнов // Конструктор-машиностроитель. - 2008. № 3. - С. $12-15$.

9. Яиун С.Ф. Динамические режимы движения клапана прецизионного дозатора жидких сред [Текст] / С.Ф. Яцун, Ж.Т. Жусубалиев, О.В. Емельянова [и др.] // Изв. вузов. Серия «Машиностроение». - 2008. - № 8. - С. 37-48.

10. Проектування пакувального обладнання із мехатронних модулів./ М.В. Якимчук, О.М. Гавва, А.П. Беспалько та ін. - К. : Видавництво «Сталь», 2017. — 515 с.

\title{
ИССЛЕДОВАНИЕ ПНЕВМАТИЧЕСКИХ ШЛАНГОВЫХ ЗАТВОРОВ В МЕХАТРОННЫХ СИСТЕМАХ ДОЗИРОВАНИЯ ЖИДКИХ ПИЩЕВЫХ ПРОДУКТОВ
}

\author{
О.Н. Горчакова, аспирант \\ Н.В. Якимчук, д-р техн. наук \\ Национальный университет пищевых технологий
}

Создание нового упаковочного оборудования для фасовки жидких продуктов, которое имеет гибкую структуру и является универсальным при изменении дозы или материала упаковки, - основная задачей сегодняшнего дня. Ее решение требует системного подхода, начиная с разработки концепции проектирования дозирующих устройств и заканчивая конструкциями исполнительных механизмов. Такой концепцией в настоящем может быть концепция использования мехатронного принципа проектирования дозирующего оборудования с использованием пневматического шланговой затвора. В работе приведены математическая модель расчета изменения эффрективной площади проходного сечения пневматического шлангового затвора. Экспериментально исследовано эфрфективную площадь проходного сечения пневматического шланговой затвора om изменения входного давления. Полученные результаты можно в дальнейшем использовать при проектировании новых дозирующих устройств для жидкостей.

Ключевые слова: система дозирования, пневматический шланговые затвор, мехатронных модуль, эфрфективная площадь. 
УДК 519.711.3: 663.52

\title{
RESEARCH OF BEHAVIOR OF BRAGORECTIFYING INSTALLATION BY WAVELET ANALYSIS METHODS
}

\author{
V. Kyshenko, D. Kryschenko, A. Kycher \\ National University of Food Technologies
}

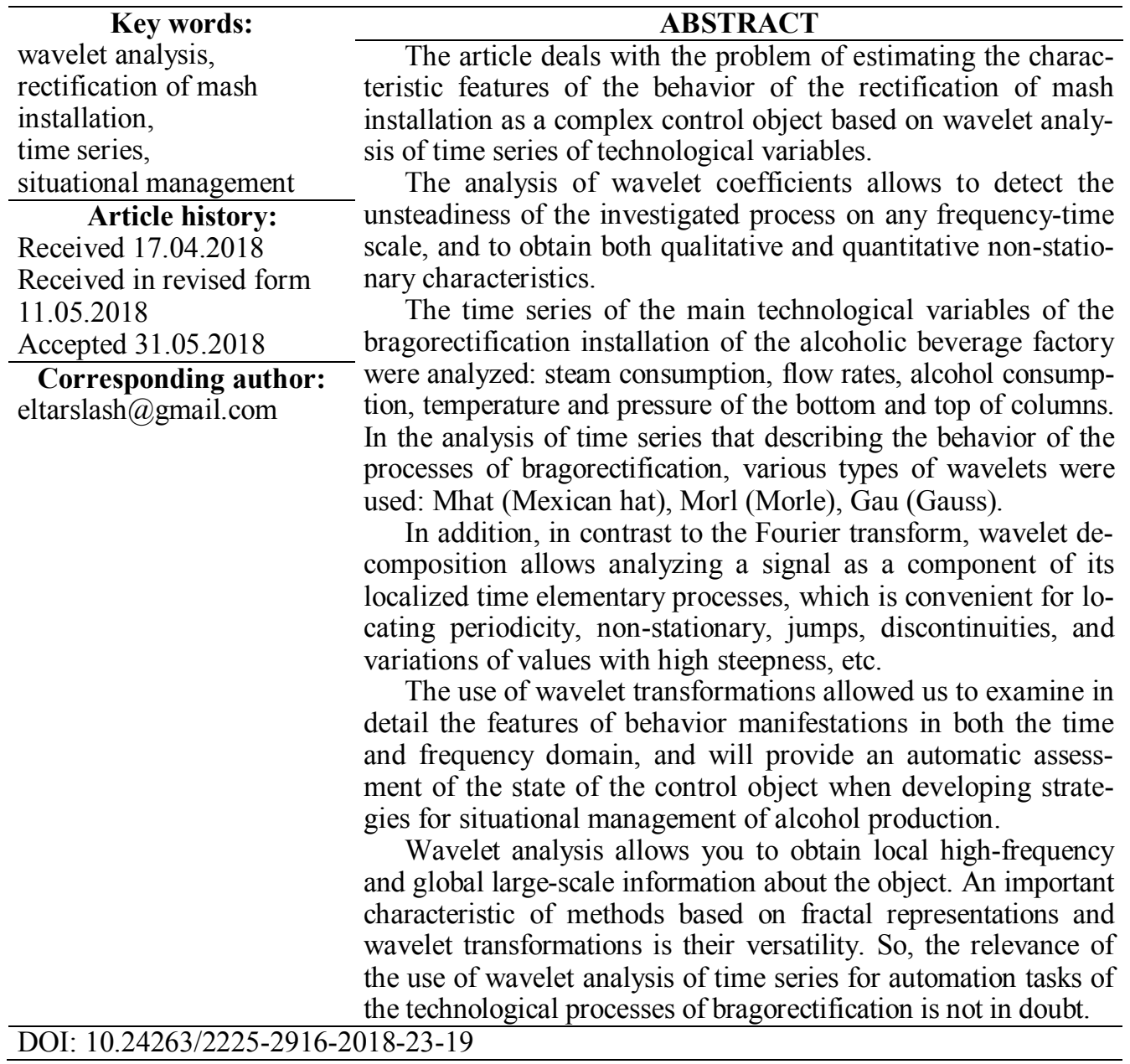

\section{ДОСЛІДЖЕННЯ ПОВЕДІНКИ БРАГОРЕКТИФІКАЦІЙНОЇ УСТАНОВКИ МЕТОДАМИ ВЕЙЛЕТ-АНАЛІЗУ}

\author{
В.Д. Кишенько, канд. техн. наук \\ Д.О. Крищенко \\ A. $\boldsymbol{\epsilon . ~ К у ч е р ~}$ \\ Національний університет харчових технологій
}

У статті розглядається проблема оцінки характерних рис поведінки брагоректифрікаційної установки як складного об'єкта керування на основі вейвлет-

(ㄱ В.Д. Кишенько, Д.О. Крищенко, А.Є. Кучер, 2018 
аналізу часових рядів технологічних змінних. Застосування вейвлет-перетворень дало змогу детально розглянути особливості проявів поведінки як в часовій, так і в частотній області, що забезпечить автоматичну оцінку стану об'єкта керування при розробці стратегій ситуаційного керування спиртовим виробництвом.

Ключові слова: вейвлет-аналіз, брагоректифрікаційна установка, часовий ряд, ситуаційне керування.

Постановка проблеми. Брагоректифікаційна установка спиртового заводу є складним технологічним об' єктом керування [1]. Для нього характерний високий рівень шумів і перешкод, значна невизначеність, суттєва нелінійність зв'язків між технологічними параметрами, істотна нестаціонарність, стохастичність і хаотичність, проблематична ситуаційна поведінка через наявність біфуркацій, сплесків, розривів та інших кардинальних змінювань станів об'єкта [2]. Такі особливості ускладнюють процес прийняття рішень щодо керування: виникає необхідність у пошуку, обгрунтуванні та прийнятті в реальному масштабі часу оперативних стратегій керування згідно із ситуаційною обстановкою в об'єкті керування, яка визначається на основі поточної та ретроспективної інформації про його поведінку. В цьому сенсі з метою забезпечення автоматичної реалізації прикладних функцій керування важливе значення набувають методи аналізу часових рядів технологічних змінних об'єкта керування [3]. Для аналізу випадкових процесів широко використовуються традиційні методи статистичного аналізу випадкових величин і функцій та спектрального аналізу Фур'є [4]. Поряд з ними в останні роки набувають поширення способи обробки сигналів, засновані на фрактальному i вейвлет-перетвореннях [5]. Вейвлет-аналіз $є$ одним 3 перспективних методів, що застосовуються нині для аналізу часових сигналів [6]. Вейвлет-перетворення добре локалізоване в часі, що дає змогу виявляти структуру досліджуваного сигналу на окремих часових інтервалах [6]. Відмітна особливість вейвлетперетворень полягає в тому, що вони поряд 3 глобальними характеристиками процесів, розкривають особливості їх локальної структури. Вейвлет-аналіз забезпечує локальну високочастотну і глобальну великомасштабну інформацію про об'єкт і дає змогу визначити, в який момент часу з'явилися ті чи інші компоненти сигналу. Тому актуальність застосування вейвлет-аналізу часових рядів для задач автоматизації технологічних процесів брагоректифікації не викликає сумніву.

Мета досліджень: проаналізувати часові ряди технологічних змінних брагоректифікаційної установки за допомогою вейвлет-перетворень, встановити характерні прояви поведінки об’єкта керування, забезпечити автоматичний моніторинг технологічних ситуацій брагоректифікації для організації оперативних ефективних стратегій керування процесами виробництва спирту.

Матеріали і методи. Розглядається математичне та чисельне моделювання часових рядів за допомогою вейвлет-аналізу. Основний алгоритм обробки будується за умови існування часового ряду і полягає у визначенні показників стохастичності, хаотичності та аналізі особливих станів системи за допомогою вейвлет-перетворення. Аналіз вейвлет-коефіцієнтів дає змогу виявити нестаціонарності досліджуваного процесу на будь-яких частотно-часових масштабах і таким чином отримати як якісні, так і кількісні характеристики нестаціонарності; установити рівень та характер шумів і збурень, діагностувати характерні прояви поведінки об'єкта керування. На відміну від перетворення Фур'є, при якому локалізуються частоти, але не дається часової ідентифікації процесу, 
вейвлет-перетворення, що користується рухомим частотно-часовим вікном, що самоорганізується, однаково добре виявляє як низькочастотні, завдяки скейлінгфункції, що здійснює грубу апроксимацію сигналу за допомогою апроксимуючих коефіцієнтів, так і високочастотні характеристики сигналу, що розкривають подробиці сигналу на основі деталізуючих коефіцієнтів, на різних часових масштабах [6].

Вейвлет-аналіз полягає в поданні вихідного сигналу, функції у вигляді лінійної комбінації деяких базових функцій — вейвлетів. Вейвлет-перетворення забезпечує двовимірну розгортку досліджуваного одновимірного сигналу, що створює можливість для аналізу властивостей сигналу одночасно в часі і за частотою. Масштабно-часова локалізація вейвлет-перетворення обумовлена принципом побудови ортогонального базису розкладання [6]. На відміну від Фур'є-перетворення, де як базис використовуються гармонійні функції [4], базис вейвлет-розкладання становить локалізована в часі, тобто швидко спадна солітоноподібна вейвлет - функція [6]:

$$
\psi_{a, b}=\psi\left(\frac{t-b}{a}\right),
$$

де $t$ - час; $a$ - масштабний коефіцієнт, що визначає величину розтягування вейвлета; $b$ має розмірність часу і визначає величину зсуву вейвлет-функції [6]. Нині існує цілий ряд таких функцій [6].

Обчислення вейвлет-перетворення здійснюється шляхом згортки досліджуваної часової послідовності $f(t)$ з вейвлет-функцією:

$$
W(a, b)=\int_{-\infty}^{+\infty} f(t) \psi_{a, b}(t) .
$$

Вейвлет-перетворення формує образ як вектор властивостей, що відтворює поточний стан технологічного процесу.

Розрізняють безперервне i дискретне перетворення. Безперервне вейвлетперетворення будується за допомогою безперервних масштабних перетворень i переносів вейвлета 3 довільними значеннями масштабного коефіцієнта $a$ i параметра зсуву $b[5]$ :

$$
W(a, b)=|a|^{-1 / 2} \int_{-\infty}^{\infty} f(t) \psi^{*}\left(\frac{t-b}{a}\right) d t,
$$

де символ * позначає операцію комплексного сполучення.

Двопараметрична функція $W(a, b)$ подає інформацію про зміну відносного внеску компонент різного масштабу в часі і називається спектром коефіцієнтів вейвлет-перетворення.

Маючи вейвлет-спектр, можна розрахувати повну енергію сигналу:

$$
E_{f}=\int f^{2}(t) d t=\iint W^{2}(a, b) \frac{d a d b}{a^{2}}
$$

і глобальний спектр енергії - розподіл повної енергії по масштабах (скейлограму вейвлет-перетворення): 


$$
E_{w}=(a)=\int W^{2}(a, b) d b .
$$

Вибір того або іншого класу вейвлет-функцій здійснюється 3 урахуванням специфіки задач дослідження та характерними рисами сигналу, що допомагає повніше виявити і підкреслити ті чи інші особливості аналізованого часового ряду. Спектр вейвлет-перетворення одномірного сигналу представляє поверхню в тривимірному просторі. Візуалізація спектра здійсняється шляхом проекції на площину 3 ізолініямиі, що дає змогу простежити зміни коефіцієнтів на різних масштабах в часі, із градієнтним заливанням відтінками сірого кольору між лініями, відображаючи частотно-часові характеристики сигналу. Час відкладається по осі абсцис, частота - по осі ординат.

Результати досліджень. Були проаналізовані часові ряди основних технологічних змінних брагоректифікаційної установки спиртового заводу: витрати пари, витрати бражки, витрати спирту, температури на контрольних тарілках колон, температури та тиску низу та верху колон. При аналізі часових рядів, що характеризують поведінку процесів брагоректифікації, використовувалися різні типи вейвлетів: Mhat (мексиканський капелюх), Morl (Морле), Gau (Гауса) [6]. Вейвлет-перетворення сигналу здійснювалося 3 використанням математичного пакета Matlab [7].

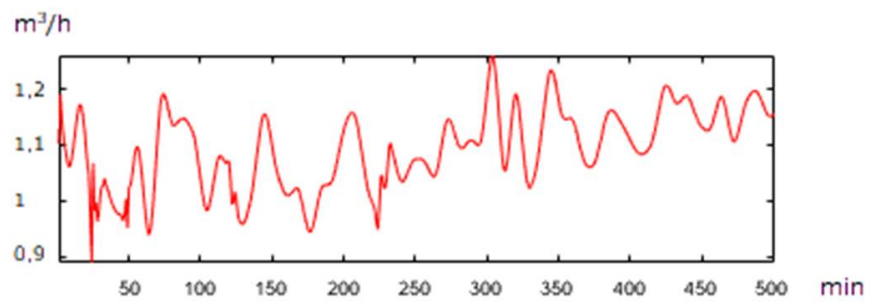

a

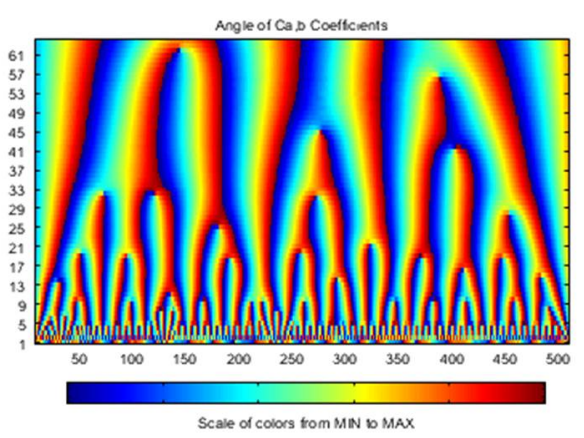

6

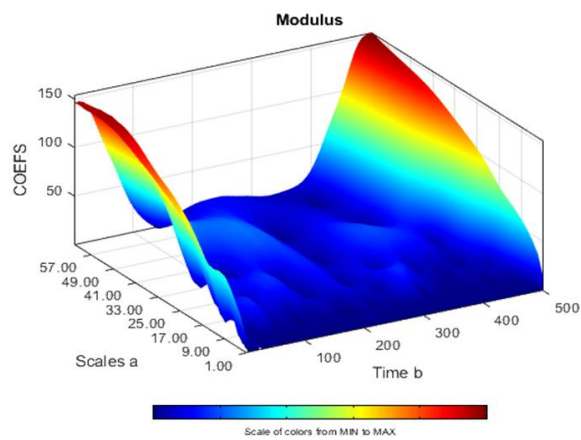

B

Рис.1. Вейвлет-перетворення Гауса часового ряду витрати спирту:

a — часовий ряд; б - вейвлет-спектограма; в — тримірний графік вейвлет-коефіцієнтів 
$\mathrm{mm}$ of wat. col.

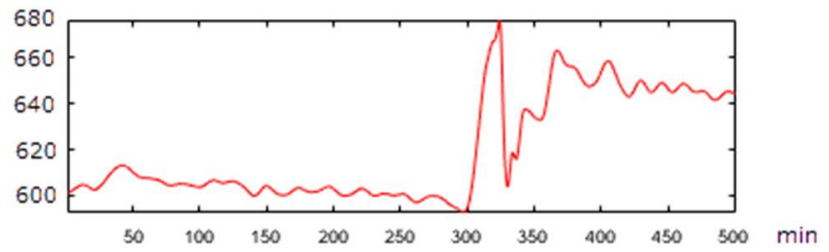

a

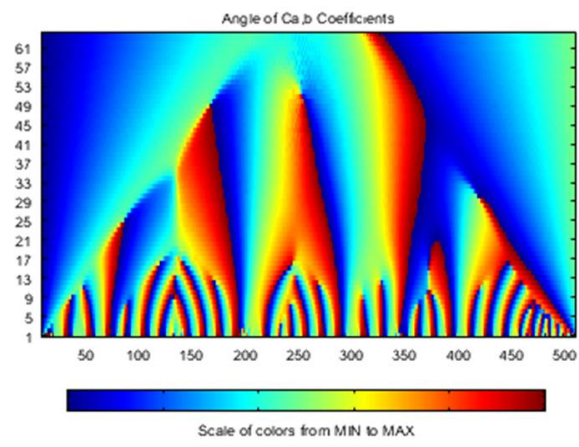

6

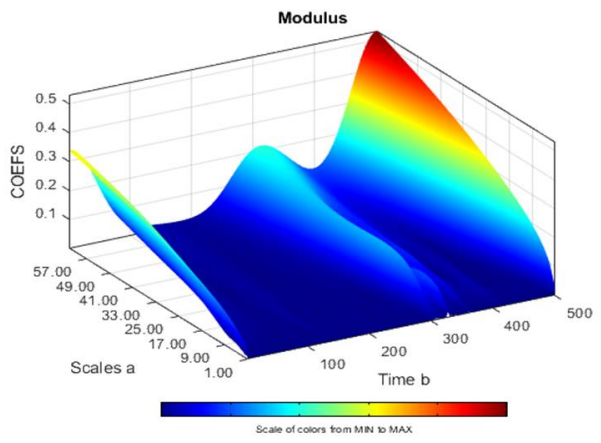

B

Рис. 2. Вейвлет-перетворення Гауса часового ряду тиску верху бражної колони:

a — часовий ряд; б - вейвлет-спектограма; в — тримірний графік вейвлет-коефіцієнтів

На рис. 1-2 зображені результати вейвлет-аналізу часових рядів ряду технологічних змінних процесу брагоректифікації, на яких видно чітку фіксацію характерних проявів поведінка об'єкта керування. Так, на рис. 1 у часовому ряді витрати спирту встановлені періодичності в поведінці, а вейвлет-спектограма сигналу свідчить про наявність високочастотних шумів 3 їх локалізацією та характеристикою частотного спектра. В часовому ряді тиску верху бражної колони (рис. 2) виявлені нестаціонарності досліджуваного процесу на певних частотно-часових масштабах, що дає змогу за розподілом вейвлет-коефіцієнтів здійснити як якісну, так і кількісну оцінку нестаціонарності. Та чи інша особливість часового ряду підкреслюється рівнем вейвлет-коефіцієнтів: чим більший рівень коефіцієнтів, тим різкіше ця особливість встановлюється і сильніше виділяється ії область в частотно-часовому спектрі, що практично неможливо при Фур'є-аналізі.

Висновки. Вейвлет-аналіз дає змогу на основі використання вейвлет-пакетів і кластеризації зробити тонкий і точний поділ частотно-часової площини на осередки таким чином, що можна одночасно розділити сигнали за частотними властивостями і за місцем розташування, що забезпечує автоматизацію задачі технологічного моніторингу при організації ефективних стратегій ситуаційного керування брагоректифікаційною колоною. 


\title{
ЛITЕРАТУРА
}

1. Ладанюк А.П. Системний аналіз складних систем управління: навч. пос. / А.П. Ладанюк, Я.В. Смітюх, Л.О. Власенко. - К. : НУХТ, 2013. - 274 с.

2. Ладанюк А.П. Інноваційні технології в управлінні складними біотехнологічними об'єктами агропромислового комплексу: монографія / А.П. Ладанюк, В.М. Решетюк, В.Д. Кишенько, Я.В. Смітюх. - К. : Центр учбової літератури, -2014. - 280 с.

3. Ярушкина Н.Г. Интеллектуальный анализ временных рядов: Учебн. пособие / Н.Г. Ярушкина, Т.В. Афанасьева, И.Г. Перфильева. - Ульяновск. : УлГТУ, 2010. - 320 с.

4. Дьяконов В.П. Цифровые анализаторы спектра, сигналов и логики / В.П. Дьяконов, А.А. Афонский. — М. : СОЛОП-Пресс, 2009. — 248 с.

5. Percival D. Wavelet methods for time series analysis / D. Percival, A. Walden. Cambrindg: Cambridge University Press, 2000. — 594 p.

6. Короновский A.A. Непрерывный вейвлетный анализ и его приложения / А.А. Короновский, А.Е. Храмов. - М. : Физматлит, 2003. - 176 с.

7. Смоленцев H.K. Основы теории вейвлетов. Вейвлеты в MATLAB/ Н.К. Смоленцев. - М. : ДМК Пресс, 2005. -304 с.

\section{ИССЛЕДОВАНИЕ ПОВЕДЕНИЯ БРАГОРЕКТИФИКАЦИОННОЙ УСТАНОВКИ МЕТОДАМИ ВЕЙВЛЕТ-АНАЛИЗА}

\author{
В.Д. Кишенько, Д.А. Крищенко, А.Е. Кучер \\ Национальный университет пищевых технологий
}

В статье рассматривается проблема оценки характерных черт поведения брагоректификационной установки как сложного объекта управления на основе вейвлет-анализа временных рядов технологических переменных. Применение вейвлет-преобразований позволило подробно рассмотреть особенности проявлений поведения как во временной, так и в частотной области, что обеспечит автоматическую оценку состояния объекта управления при разработке стратегий ситуационного управления спиртовым производством.

Ключевые слова: вейвлет-анализ, брагоректификационная установка, временной ряд, ситуационное управление. 
УДК 681.513.5

\title{
NUMERICAL SIMULATION OF THE D-DOMAIN OF STABILITY OF LINEAR DYNAMICAL SYSTEMS WITH FRACTIONAL ORDER
}

\author{
O. Lobok, B. Goncharenko, M. Sych \\ National University of Food Technologies \\ L. Vihrova \\ Central Ukrainian National Technical University
}

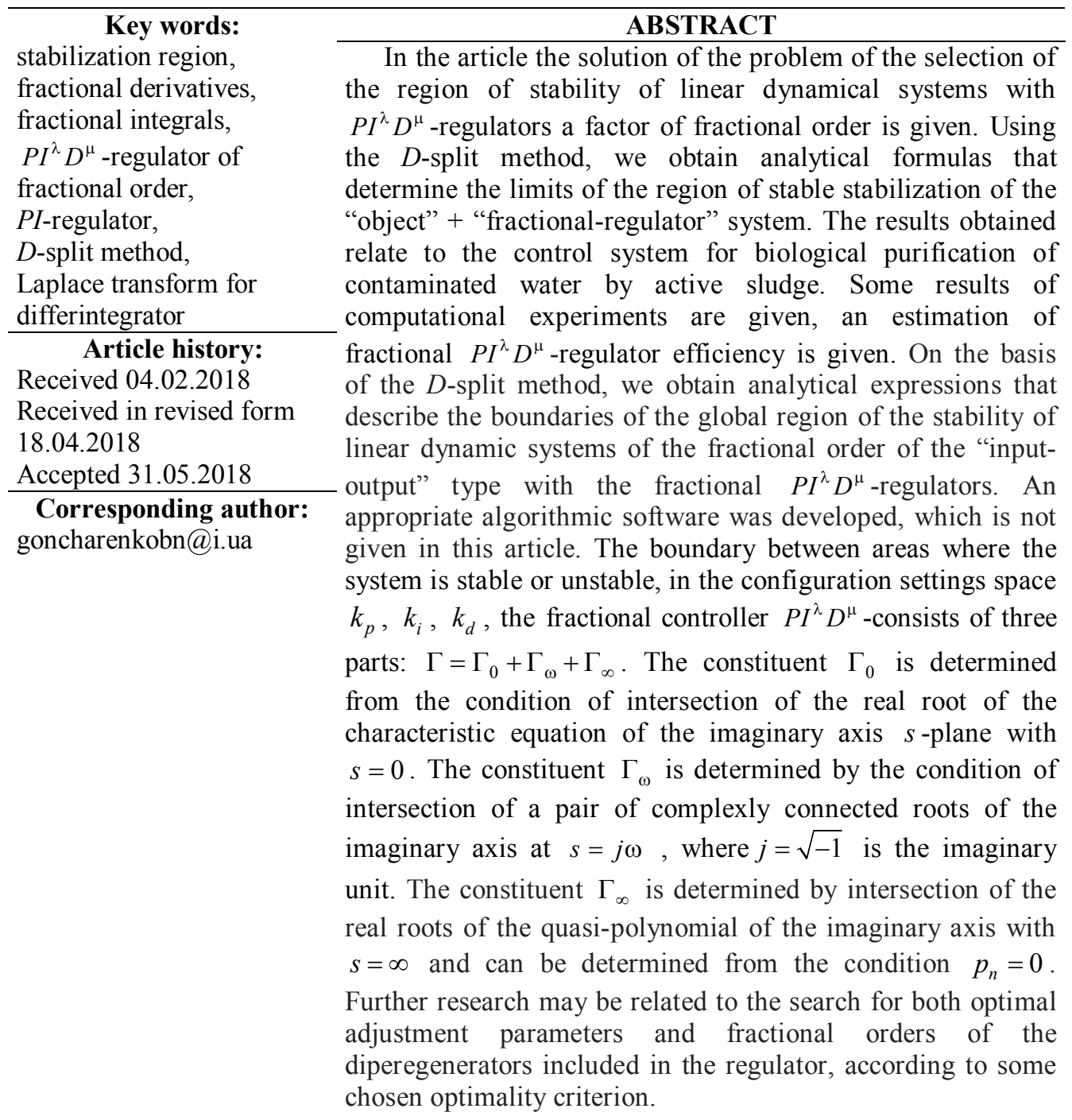

DOI: $10.24263 / 2225-2916-2018-23-20$

( ) О.П. Лобок, Б.М. Гончаренко, М.А. Сич, Л.Г. Віхрова, 2018 


\title{
ЧИСЕЛЬНЕ МОДЕЛЮВАННЯ D-ОБЛАСТІ СТІЙКОСТІ ДРОБОВИХ ЛІНІЙНИХ ДИНАМІЧНИХ СИСТЕМ
}

\author{
О.П. Лобок, канд. фіз.-мат. наук \\ Б.М. Гончаренко, д-р техн. наук \\ М.А. Сич, канд. техн. наук \\ Національний університет харчових технологій \\ Л.Г. Віхрова, канд. техн. наук \\ Центральноукраїнський національний технічний університет
}

У статmі на основі аналітичного розв'язку завдання виділення D-області стійкості лінійних динамічних систем з $\mathrm{PI}^{\lambda} \mathrm{D}^{\mu}$-регулятором дробового порядку наводяться деякі результати обчислювальних експериментів. Завдяки використанню методу D-розбиття отримані аналітичні фоормули, що визначають $D$ межі області стійкої стабілізації системи «об'єкт» + «дробовий $P{ }^{\lambda} D^{\mu}$-регулятор». Отримані результати використані для обчислювального експерименту стосовно керування біологічним очищенням забруднених вод активним мулом. Оцінено ефективність застосування дробового $\mathrm{Pl}^{\lambda} \mathrm{D}^{\mu}$-регулятора.

Ключові слова: область стабілізації, дробові похідні, дробові інтеграли, $P I^{\lambda} D^{\mu}$ регулятор дробового порядку, Pl-регулятор, метод D-розбиття, перетворення Лапласа для диферінтегратора.

Постановка проблеми. 3 початку розвитку теорії інтегро-диференціального числення дробового порядку [1] іiі перші застосування в задачах керування 3'явилися тільки близько 50 років тому [2]. Дробове числення стає ефективним інструментом для опису значного числа динамічних систем. Класичні результати теорії PID-регулювання поширилися і на регулятори дробового порядку, які позначають як $P I^{\lambda} D^{\mu}$, де $\lambda$ и $\mu$ - порядки інтегрування і диференціювання сигналу похибки, що можуть мати дійсні не цілі (дробові) значення [3; 4].

Обчислювальні експерименти проводилися в середовищі математичної системи MATLAB в просторі параметрів налаштування $P I^{\lambda} D^{\mu}$-регулятора в залежності від значення порядків степенів $\lambda$ и $\mu$.

Метою статті є моделювання застосування методу $D$-розбиття до систем автоматичного керування технологічними процесами з дробовими регуляторами.

Викладення основних результатів дослідження. Передавальна функція дробового регулятора має вигляд:

$$
C(s)=k_{p}+k_{i} s^{-\lambda}+k_{d} s^{\mu},
$$

де $\lambda$ и $\mu$ - дробові порядки, значення яких належить до області від 0 до $1 ; k_{p}$, $k_{i}, k_{d}$ - налаштовувальні параметри регулятора.

У часовій області передавальній функції (1) відповідає керування виду:

$$
u(t)=k_{p} \cdot e(t)+k_{i} \cdot\left({ }_{0} D_{t}^{-\lambda} e(t)\right)+k_{d} \cdot\left({ }_{0} D_{t}^{\mu} e(t)\right),
$$

де - ${ }_{0} D_{t}^{\gamma}$ диферінтегратор. 
Завдання полягає в тому, щоб віднайти $D$-область стійкості при допустимих значеннях параметрів налаштувань $k_{p}, k_{i}, k_{d}$ дробового $P I^{\lambda} D^{\mu}$-регулятора, які стабілізують об'єкт керування, що важливо і при конструюванні $P I^{\lambda} D^{\mu}$-регуляторів, і при пошуку оптимальних параметрів налаштувань регуляторів на знайденій параметричній області стабілізації за обраним критерієм.

Передавальна функція системи «об'єкт + регулятор» має вигляд:

$$
W(s)=\frac{C(s) G(s)}{1+C(s) G(s)}=\frac{Q(s)}{P(s)},
$$

де

$$
\begin{gathered}
Q(s)=\sum_{j=0}^{n}\left[k_{p} b_{j} s^{\lambda+\beta_{j}}+k_{i} b_{j} s^{\beta_{j}}+k_{d} b_{j} s^{\lambda+\mu+\beta_{j}}\right] ; \\
P(s)=\sum_{j=0}^{n}\left[a_{j} s^{\lambda+\alpha_{j}}+k_{p} b_{j} s^{\lambda+\beta_{j}}+k_{i} b_{j} s^{\beta_{j}}+k_{d} b_{j} s^{\lambda+\mu+\beta_{j}}\right] .
\end{gathered}
$$

Поліном $P(s)$ для зручності подамо у вигляді:

$$
P(s)=\sum_{j=0}^{n} p_{j} s^{q_{j}}=p_{n} s^{q_{n}}+p_{n-1} s^{q_{n-1}}+\ldots+p_{1} s^{q_{1}}+p_{0} s^{q_{0}},
$$

де $q_{j}$ - впорядковані дробові порядки степенів, причому $q_{n}>q_{n-1}>\ldots>q_{0} ; p_{j}-$ коефіцієнти, які визначаються коефіцієнтами передавальної функції об'єкта керування і параметрами налаштувань $k_{p}, k_{i}, k_{d}$ дробового $P I^{\lambda} D^{\mu}$-регулятора.

Для виділення області стійкої стабілізації системи (об'єкта керування 3 регулятором) використовуємо метод $D$-розбиття простору параметрів [6]. Нагадаємо, що згідно з цим методом границя між областями стійкості і нестійкості в просторі параметрів налаштувань складається трьома частинами: $\Gamma=\Gamma_{0}+\Gamma_{\omega}+\Gamma_{\infty}$. Складова $\Gamma_{0}$ визначається з умови перетину дійсним коренем характеристичного рівняння уявної осі $s$-площини при $s=0$. Тобто складову $\Gamma_{0}$ знаходять шляхом підстановки $s=0$ в рівняння $P(s)=0$, де $P(s)$ визначається рівнянням (6). Звідси випливає, що $\Gamma_{0}$ може бути визначена з умови $p_{0}=0$, якщо значення найменшого порядку $q_{0}$ дорівнює 0 , тобто при $s^{q_{0}}=1$. Якщо $q_{0} \neq 0$, тобто $s^{q_{0}} \neq 1$, то границі $\Gamma_{0}$ не існує. Складова $\Gamma_{\omega}$ визначається 3 умови перетину парою комплексно сполучених коренів уявної осі при $s=j \omega$, де $j=\sqrt{-1}-$ уявна одиниця. В цьому випадку поліном (6) стає нестійким і дійсна і уявна частини рівняння $P(j \omega)=0$ починають дорівнювати нулю одночасно. Складова $\Gamma_{\omega}$ визначається перетином дійсними коренями полінома (6) уявної осі при $s=\infty$ і може бути визначена з умови $p_{n}=0$.

Застосовуючи ці передумови до досліджуваної системи «об'єкт + регулятор» i аналізуючи характеристичний поліном (5), приходимо до висновку, що складові $\Gamma_{0}$ та $\Gamma_{\omega}$ границі області стійкості являють собою прямі лінії: 


$$
\Gamma_{0} \text { — лінія: }\left\{\begin{array}{l}
k_{i}=0, \quad \text { при } s^{\beta_{0}}=1, \\
\text { не існує, при } s^{\beta_{0}} \neq 1,
\end{array}\right.
$$

$\Gamma_{\infty}$ - лінія:

$$
\begin{cases}k_{d}=0, & \text { при }\left(\alpha_{n}=\beta_{n}\right) \text { або }\left(\alpha_{n}>\beta_{n} \text { і } \mu>\alpha_{n}-\beta_{n}\right), \\ k_{d}=-a_{n} / b_{n}, & \text { при }\left(\alpha_{n}>\beta_{n} \text { i } \mu=\alpha_{n}-\beta_{n}\right), \\ \text { не існує, } & \text { при }\left(\alpha_{n}>\beta_{n} \text { i } \mu<\alpha_{n}-\beta_{n}\right) .\end{cases}
$$

Для побудови складової $\Gamma_{\omega}$ підставим $s=j \omega$ в рівняння $P(s)=0$, де $P(s)$ поліном (5). Тоді отримаємо:

$$
\begin{gathered}
P(j \omega)=\sum_{j=0}^{n}\left[a_{j}(j \omega)^{\lambda+\alpha_{j}}+k_{p} b_{j}(j \omega)^{\lambda+\beta_{j}}+k_{i} b_{j}(j \omega)^{\beta_{j}}+k_{d} b_{j}(j \omega)^{\lambda+\mu+\beta_{j}}\right]= \\
=\operatorname{Re}\{P(j \omega)\}+j \cdot \operatorname{Im}\{P(j \omega)\}=0,
\end{gathered}
$$

де $\operatorname{Re}\{P(j \omega)\}$ та $\operatorname{Im}\{P(j \omega)\}$ означають відповідно дійсну та уявну частини квазіполінома $P(j \omega)$.

Для подальшого перетворення виразу (7) пригадаємо, що не цілий степінь комплексного числа $(\sigma+j \omega)^{\gamma}$ може бути вирахований за формулою МуавраЛапласа:

$$
(\sigma+j \omega)^{\gamma}=\left(\sigma^{2}+\omega^{2}\right)^{\gamma / 2}[\cos (\gamma \varphi)+j \sin (\gamma \varphi)]
$$

де $\varphi=\arctan (\omega / \sigma) ; \sigma-$ дійсна частина; $\omega-$ уявна частина; $\gamma$ - дробовий порядок комплексного числа.

Вираз $j^{\gamma}$ у рівнянні (7) може бути представлений згідно з формулою (8) так:

$$
j^{\gamma}=\cos \left(\frac{\pi}{2} \gamma\right)+j \sin \left(\frac{\pi}{2} \gamma\right)
$$

Далі, прирівнявши до нуля дійсну і уявну частину рівняння (7), з урахуванням формули (9), отримаємо

$$
\left\{\begin{array}{l}
\operatorname{Re}\{P(j \omega)\}=k_{p} R_{1 p}(\omega)+k_{i} R_{1 i}(\omega)+k_{d} R_{1 d}(\omega)+H_{1}(\omega)=0 \\
\operatorname{Im}\{P(j \omega)\}=k_{p} R_{2 p}(\omega)+k_{i} R_{2 i}(\omega)+k_{d} R_{2 d}(\omega)+H_{2}(\omega)=0
\end{array}\right.
$$

де

$$
R_{1 p}(\omega)=\sum_{j=0}^{n} b_{j} \omega^{\lambda+\beta_{j}} \cos \left(\frac{\pi}{2}\left(\lambda+\beta_{j}\right)\right), R_{1 i}(\omega)=\sum_{j=0}^{n} b_{j} \omega^{\beta_{j}} \cos \left(\frac{\pi}{2} \beta_{j}\right)
$$




$$
\begin{gathered}
R_{1 d}(\omega)=\sum_{j=0}^{n} b_{j} \omega^{\lambda+\mu+\beta_{j}} \cos \left(\frac{\pi}{2}\left(\lambda+\mu+\beta_{j}\right)\right), H_{1}(\omega)=\sum_{j=0}^{n} a_{j} \omega^{\lambda+\alpha_{j}} \cos \left(\frac{\pi}{2}\left(\lambda+\alpha_{j}\right)\right) ; \\
R_{2 p}(\omega)=\sum_{j=0}^{n} b_{j} \omega^{\lambda+\beta_{j}} \sin \left(\frac{\pi}{2}\left(\lambda+\beta_{j}\right)\right), R_{2 i}(\omega)=\sum_{j=0}^{n} b_{j} \omega^{\beta_{j}} \sin \left(\frac{\pi}{2} \beta_{j}\right) ; \\
R_{2 d}(\omega)=\sum_{j=0}^{n} b_{j} \omega^{\lambda+\mu+\beta_{j}} \sin \left(\frac{\pi}{2}\left(\lambda+\mu+\beta_{j}\right)\right), H_{2}(\omega)=\sum_{j=0}^{n} a_{j} \omega^{\lambda+\alpha_{j}} \sin \left(\frac{\pi}{2}\left(\lambda+\alpha_{j}\right)\right) .
\end{gathered}
$$

Система лінійних рівнянь (10) містить більше невідомих $\left(k_{p}, k_{i}, k_{d}\right)$, ніж число рівнянь, то для однозначного іiі розв'язання один із параметрів системи може бути обраний довільно. Якщо як цей параметр обрати коефіцієнт $k_{p}$, то система (10) стає системою лінійних алгебраїчних рівнянь другого порядку щодо невідомих $k_{i}$ та $k_{d}$, розв'язок якої має вигляд:

$$
\begin{gathered}
k_{i}=\frac{\Delta_{i}(\omega)}{\Delta(\omega)}, k_{d}=\frac{\Delta_{d}(\omega)}{\Delta(\omega)} \\
\Delta_{i}(\omega)=R_{1 d}(\omega) H_{2}(\omega)-R_{2 d}(\omega) H_{1}(\omega)+k_{p}\left(R_{1 d}(\omega) R_{2 p}(\omega)-R_{1 p}(\omega) R_{2 d}(\omega)\right) \\
\Delta_{d}(\omega)=R_{2 i}(\omega) H_{1}(\omega)-R_{1 i}(\omega) H_{2}(\omega)+k_{p}\left(R_{1 p}(\omega) R_{2 i}(\omega)-R_{1 i}(\omega) R_{2 p}(\omega)\right) ; \\
\Delta(\omega)=R_{1 i}(\omega) R_{2 d}(\omega)-R_{1 d}(\omega) R_{2 i}(\omega)=\omega^{\lambda+\mu} \sin \left(\frac{\pi}{2}(\lambda+\mu)\right)\left(R_{1 i}^{2}(\omega)+R_{2 i}^{2}(\omega)\right) .
\end{gathered}
$$

Зауважимо, що для дробового $P I^{\lambda}$-регулятора $\left(k_{d}=0\right)$ система (10) має єдиний розв'язок:

$$
\begin{gathered}
k_{p}=\frac{\Delta_{p}(\omega)}{\Delta(\omega)}, k_{i}=\frac{\Delta_{i}(\omega)}{\Delta(\omega)} \\
\Delta_{p}(\omega)=H_{2}(\omega) R_{1 i}(\omega)-H_{1}(\omega) R_{2 i}(\omega), \Delta_{i}(\omega)=H_{1}(\omega) R_{2 p}(\omega)-H_{2}(\omega) R_{1 p}(\omega), \\
\Delta(\omega)=R_{1 p}(\omega) R_{2 i}(\omega)-R_{1 i}(\omega) R_{2 p}(\omega)=-\omega^{\lambda} \sin \left(\frac{\pi}{2} \lambda\right)\left(R_{1 i}^{2}(\omega)+R_{2 i}^{2}(\omega)\right) .
\end{gathered}
$$

Застосуємо тепер ці результати для обчислювального експерименту виділення області стійкості системи керування біологічним очищенням забруднених вод активним мулом 3 дробовим $P I^{\lambda} D^{\mu}$-регулятором. У [7] була отримана лінеаризована модель біоочисної системи «аеротенк + відстійник» у вигляді моделі з одним входом і одним виходом:

$$
\frac{d x(t)}{d t}=A x(t)+b u(t), y(t)=x_{2}(t)=c^{T} x(t),
$$


де $x(t)=\left(x_{1}(t), x_{2}(t), x_{3}(t)\right)^{T}$ - вектор стану, в якому $x_{1}(t), x_{2}(t)$ - відповідно, концентрація біомаси і субстрату в аеротенку; $x_{3}(t)-$ концентрація рециркулюючої біомаси з відстійника в біореактор-аеротенк; $u(t)$ - одномірна функція керування-швидкість розведення (аналог об'ємної швидкості потоку); $y(t)$ - спостережуваний вихід системи - концентрація субстрату.

Системна матриця $A$ і вектори $b$ и $c$ визначаються так:

$$
A=\left(\begin{array}{lll}
a_{11} & a_{12} & a_{13} \\
a_{21} & a_{22} & a_{23} \\
a_{31} & a_{32} & a_{33}
\end{array}\right), b=\left(\begin{array}{l}
b_{1} \\
b_{2} \\
b_{3}
\end{array}\right), c=\left(\begin{array}{l}
0 \\
1 \\
0
\end{array}\right),
$$

де

$$
\begin{gathered}
a_{1,1}=\mu_{\max } \frac{x_{2}^{*}}{k_{s}+x_{2}^{*}}-(1+r) u^{*}, a_{1,2}=\mu_{\max } k_{s} \frac{x_{1}^{*}}{\left(k_{s}+x_{2}^{*}\right)^{2}}, a_{1,3}=r u^{*}, \\
a_{2,1}=-\frac{\mu_{\max }}{Y} \frac{x_{2}^{*}}{k_{s}+x_{2}^{*}}, a_{2,2}=-\frac{\mu_{\max } k_{s}}{Y} \frac{x_{1}^{*}}{\left(k_{s}+x_{2}^{*}\right)^{2}}-(1+r) u^{*}, a_{2,3}=0, \\
a_{3,1}=(1+r) u^{*}, a_{3,2}=0, a_{3,3}=-(\beta+r) u^{*}, \\
b_{1}=-(1+r) x_{1}^{*}+r x_{3}^{*}, b_{2}=-(1+r) x_{2}^{*}+s_{i n}, b_{3}=-(\beta+r) x_{3}^{*}+(1+r) x_{1}^{*} .
\end{gathered}
$$

Тут позначено: $u^{*}$ - задане номінальне керування; $x^{*}=\left(x_{1}^{*}, x_{2}^{*}, x_{3}^{*}\right)^{T}$ відповідний йому обчислений вектор рівноважного стану; $\mu_{\max }$ - максимальна питома швидкість росту біомаси; $k_{s}$ - константа насичення, що визначається експериментальним шляхом; $s_{i n}$ - концентрація субстрату у вхідному потоці; $Y$ - чинник виходу (прибутковості) біомаси; $r, \beta-$ коефіцієнти, що визначають відповідно відношення рециркуляційного потоку і потоку відходів біомаси до вхідного потоку.

Чисельне моделювання керованої системи біоочищення здійснювалося при таких вихідних даних: $s_{i n}=200$ [мг/л], $Y=0,65, \mu_{\max }=0,15$ [год $\left.{ }^{-1}\right], k_{s}=100$ [мг/л], $r=0,6, \beta=0,2, u^{*}=0,05$ [год $\left.{ }^{-1}\right], t_{0}=0, T=1$ [год], вектор початкового стану системи (15) покладався рівним $x^{0}=\left(x_{1}^{0}, x_{2}^{0}, x_{3}^{0}\right)^{T}=(286 ; 17 ; 568)^{T}$ [мг/л].

Відзначимо, що вектор рівноважного стану системи (15) при цих даних був обчислений як розв'язок відповідної системи нелінійних рівнянь третього порядку і дорівнював $x^{*}=\left(x_{1}^{*}, x_{2}^{*}, x_{3}^{*}\right)^{T}=(285 ; 15,38 ; 570)^{T}$.

У частотній області модель (15) може бути представлена у вигляді:

$$
Y(s)=G(s) U(s),
$$

де $U(s), Y(s)$ - перетворення Лапласа відповідно входу і виходу; $G(s)$ передавальна функція об'єкта керування: 


$$
G(s)=c^{T}(s E-A)^{-1} b=\frac{c^{T} \operatorname{adj}(s E-A) b}{\operatorname{det}(s E-A)}=\frac{p_{2} s^{2}+p_{1} s+p_{0}}{s^{3}+q_{2} s^{2}+q_{1} s+q_{0}} .
$$

Тут через $\operatorname{adj}(s E-A)$ позначена приєднана матриця матриці $s E-A$, а коефiцієнти $p_{i}, q_{i}$ поліномів чисельника і знаменника обчислюються за формулами:

$$
\begin{gathered}
p_{0}=b_{2} a_{11} a_{33}-b_{1} a_{21} a_{33}-b_{2} a_{13} a_{31}, q_{0}=a_{12} a_{21} a_{33}+a_{13} a_{31} a_{22}-a_{11} a_{22} a_{33}, \\
p_{1}=b_{1} a_{21}-b_{2} a_{11}-b_{2} a_{33}, q_{1}=a_{11} a_{22}+a_{11} a_{33}+a_{22} a_{33}-a_{13} a_{31}-a_{12} a_{21}, \\
p_{2}=b_{2}, q_{2}=-a_{11}-a_{22}-a_{33} .
\end{gathered}
$$

Якщо керування $u(t)$ в часовій області конструювати в класі дробових $P I^{\lambda} D^{\mu}$-регуляторів виду (1):

$$
u(t)=-\left(k_{p} \cdot y(t)+k_{i} \cdot\left({ }_{0} D_{t}^{-\lambda} y(t)\right)+k_{d} \cdot\left({ }_{0} D_{t}^{\mu} y(t)\right)\right),
$$

то передавальна функція системи «біоочищення» + «регулятор» буде визначатися виразом $W(s)=Q(s) / P(s)$, де $Q(s)=C(s) G(s) ; P(s)=1+C(s) G(s) ; C(s)-$ передавальна функція дробового регулятора, що визначається за формулою (1); $G(s)$ - передавальна функція об’єкта керування, що обчислюється за формулами (16), (17).

Для визначення області допустимих значень параметрів налаштування $k_{p}$, $k_{i}, k_{d}$ дробового $P I^{\lambda} D^{\mu}$-регулятора, який стабілізує роботу біоочисної системи, використовувалися розрахункові формули (11), (12) і (13), (14), які описують границі областей стійкості системи 3 дробовим регулятором. Обчислювальні експерименти, як вказувалося, проводилися в середовищі математичної системи MATLAB. Нижче представлені деякі результати обчислювальних експериментів.

На рис. 1 в просторі параметрів $Z=\left\{k_{p}, k_{i}\right\}$ представлена глобальна область стійкості (заштрихована область) біоочисної системи 3 дробовим $P I^{\lambda}$-регулятором при $\lambda=1$, тобто при використанні класичного $P I$-регулятора $\left(\Gamma_{\omega}, \Gamma_{0}-\right.$ границі області стійкості).

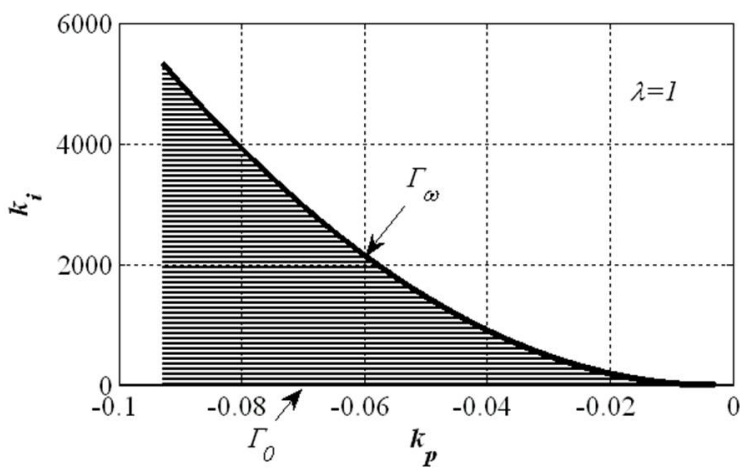

Рис. 1. Глобальна область стійкості системи з $P I^{\lambda}$-регулятором при $\lambda=1$ 
На рис. 2 побудовані області стійкості системи біоочищення 3 дробовим $P I^{\lambda}$-регулятором при різних значеннях порядку диферінтегратора. Тут області стійкості обмежені знизу віссю абсцис, а зверху — кривою, що відповідає значенню порядку параметра. 3 графіків видно, що із збільшенням порядку також збільшується область стійкості системи.

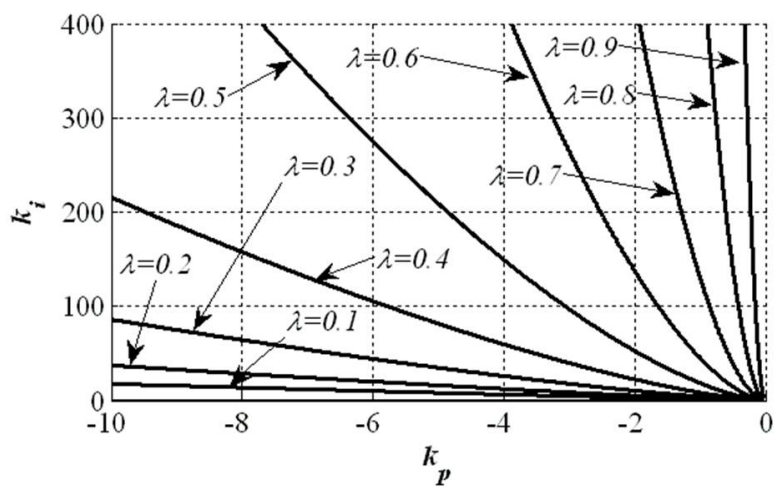

Рис. 2. Глобальні області стійкості системи біоочищення з $\mathrm{PI}^{\lambda}$-регулятором при $0<\lambda<1$

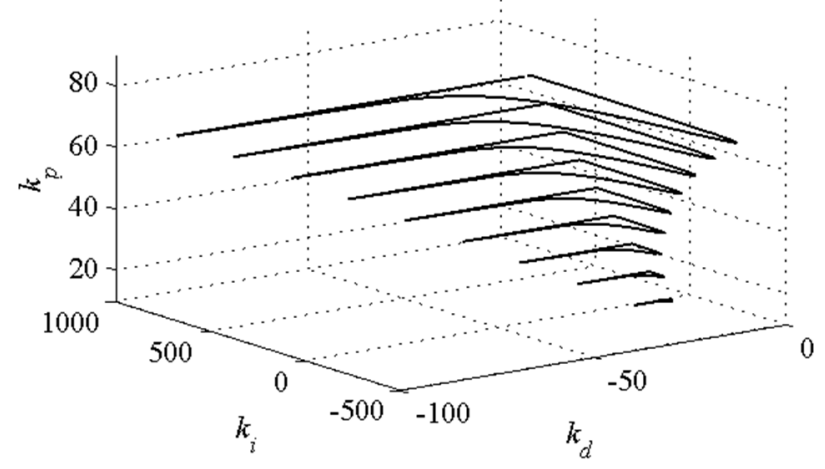

Рис. 3. Глобальна область стійкості системи з $P^{\lambda} D^{\mu}$-регулятором при $\lambda=0,7, \mu=0,1$

На рис. 3 представлені перетини області стійкості площинами, перпендикулярними до координатної осі. Перетини є замкнутими фігурами, площі яких збільшуються з ростом параметра налаштування.

Подібні області стійкості були отримані і при інших значеннях дробових порядків $\lambda$ i $\mu$.

Висновки. На основі методу $D$-розбиття отримані аналітичні вирази, які описують границі глобальної області стійкості лінійних динамічних систем дробового порядку типу «вхід-вихід» 3 дробовим $P I^{\lambda} D^{\mu}$-регулятором. Області стійкості побудовані на основі обчислювальних експериментів у просторі параметрів налаштування дробових $P I^{\lambda} D^{\mu}$-регуляторів при фіксованих порядках диферінтеграторів у складі регулятора. Розроблене відповідне алгоритмічнопрограмне забезпечення. 


\title{
ЛІТЕРАТУРА
}

1. Podlubny I. Fractional Differential Equations / Mathematics in Sciences and Engineering, Vol. 198. - Academic Press, 1999. - 340 p.

2. Tustin A., Allason J.T., Layton J.M., Jakeways R.J.: The design of systems for automatic control of the position of massive object. / Proc. Inst. Electr. Eng. 105 (C-1), 1958, pp. $1-57$.

3. Podlubny I. Fractional-order systems and PID controllers. IEEE Transactions on Automatic Control, 1999, vol. 44, pp. 208-214.

4. Бутковский А.Г., Постнов С.С., Постнова Е.А. Дробное интегро-дифференциальное исчисление и его приложения в теории управления. II. Дробные динамические системы: моделирование и аппаратная реализация // Автоматика и телемеханика. 2013. - № 5. - С. 3-34.

5. Учайкин В.В. Метод дробных производных, Артишок, Ульяновск, 2008. - 512 с.

6. Hamamci S.E., Tan N. Design of PI controllers for achieving time and frequency domain specifications simultaneously / ISA Trans. Vol. 45(4), 2006, pp. 529-543.

7. Лобок О.П., Гончаренко Б.М., Сич М.А., Віхрова Л.Г. Моделювання оптимального автоматичного керування процесом біологічної очистки забруднених вод регуляторами дробового порядку. Збірник наук. праць Кіровоградського національного технічного університету - Техніка в сільськогосподарському виробництві, галузеве машинобудування, автоматизація, № 30. - Кропивницький : КНТУ, 2017 р. — С. 152-160.

\section{ЧИСЛОВОЕ МОДЕЛИРОВАНИЕ D-ОБЛАСТИ УСТОЙЧИВОСТИ ДРОБНЫХ ЛИНЕЙНЫХ ДИНАМИЧЕСКИХ СИСТЕМ}

\author{
А.П. Лобок, Б.Н. Гончаренко, М.А. Сыч \\ Национальный университет пищевых технологий \\ Л.Г. Вихрова \\ Центральноукраинский национальный технический университет
}

В статье дается решение задачи числового моделирования области устойчивости линейных динамических систем с $P^{\lambda} D^{\mu}$-регуляторами дробного порядка. Используя метод D-разбиения, получены аналитические формулы, определяющие пределы области устойчивой стабилизации системы «объект» + «дробный $P I^{\lambda} D^{\mu}$-регулятор». Полученные результаты касаются системы автоматического управления биологической очисткой загрязненных вод активным илом. Приводятся некоторые результаты вычислительных экспериментов. Ключевые слова: область стабилизации, дробные производные, дробные интегралы, $P I^{\lambda} D^{\mu}$-регулятор дробного порядка, PI-регулятор, метод D-разбиения, преобразование Лапласа для диферинтегратора. 


\title{
Удк 664.51
}

\section{PROPOSALS FOR USE OF CLOSED ENERGY-MATERIAL CONTOURS}

\author{
A. Sokolenko, K. Vasylkivsky, O. Stepanets, M. Juhno \\ National University of Food Technologies
}

\begin{tabular}{l}
\multicolumn{1}{c}{ Key words: } \\
closed contours, \\
mass exchange processes, \\
energy potential, \\
technology, \\
industry, \\
secondary resource, \\
scheme, \\
apparatus \\
\hline
\end{tabular}

Article history:

Received 25.03.2018

Received in revised form

25.04.2018

Accepted 03.06.2018

Corresponding author: mif63@i.ua

\begin{abstract}
The article deals with the physical and thermodynamic basis of the creation of contours of closed energy use in food technologies. Information is provided on non-traditional approaches in assessing the possibilities of utilizing secondary energy resources in four directions, namely: in the direction of the impact on recycled environments with concentrated energy flows; increase of energy potentials of environments due to their saturation with easily soluble gases; intensification of mass-exchange processes in gas-liquid media; combinations of changes in internal potentials of environments and external energy flows, with a combination of recovery and regeneration processes.

On the example of the brewing industry, the structure of material and energy losses and examples of the synthesis of closed energy circuits at the malt production stage are shown, the possibilities and feasibility of transformations of secondary energy resources for the majority of food technologies are shown.

The expediency of using closed circuits corresponds to solving problems of heating and cooling products. The best efficiency cases correspond to the modes of pasteurization of products in the flow, when the input and output streams interact through the heat transfer surface. It is important, however, that this is one and the same surface for opposing flows, as opposed to cases of use of additional contours.

The article provides information on arrangement of the scheme of the device for the recuperative return of thermal energy in the heat exchange systems between the two gas streams, devices for mowing, desaturation of recirculation air, systems of integrated use of energy flows in dryers and grain sprouting machines.

Concerning closed energy-material contours, it is expedient to use phase transitions in them to amplify heat transfer and heat transfer processes.
\end{abstract}

\section{ПРОПОЗИЦІї ДО ВИКОРИСТАННЯ ЗАМКНУТИХ ЕНЕРГОМАТЕРІАЛЬНИХ КОНТУРІВ}

\author{
А.І. Соколенко, д-р техн. наук \\ К.В. Васильківський, канд. техн. наук \\ O.І. Степанець, канд. техн. наук \\ М.І. Юхно, канд. техн. наук \\ Національний університет харчових технологій \\ Стаття стосується фрізичного і термодинамічного підгрунтя створення кон- \\ турів замкнутого енергокористування в харчових технологіях. Наведена
}

(C) А.І. Соколенко, К.В. Васильківський, О.І. Степанець, М.І. Юхно, 2018 
інформація щодо нетрадиційних підходів в оцінках можливостей використання вторинних енергетичних ресурсів у чотирьох напрямках, а саме: в напрямку впливів на перероблювані середовища з концентрованими енергетичними потоками; підвищення енергетичних потенціалів середовищ за рахунок насичення їх легкорозчинними газами; інтенсифрікації масообмінних процесів у газорідинних середовищах; комбінацій змін внутрішніх потенціалів середовищ і зовнішніх енергетичних потоків, з поєднанням процесів рекуперації і регенерації.

На прикладі пивоварної галузі наведено структуру матеріальних і енергетичних втрат і приклади синтезу замкнутих енергетичних контурів на етапі виробництва солоду, показані можливості і доцільність трансформацій вторинних енергетичних ресурсів для більшості харчових технологій.

Ключові слова: замкнуті контури, масообмінні процеси, енергетичний потенціал, технологія, промисловість, вторинний ресурс, схема, апарат.

Постановка проблеми. Відповідно до завдань Державної стратегії регіонального розвитку на період до 2020 р., затвердженої постановою Кабінету Міністрів України від 06.08.2014 № 385, в рамках програми розвитку інноваційної економіки та інвестицій основними принципами реалізації державної політики є підвищення енергоефективності підприємств, збільшення частки енергії, отриманої з відновлюваних джерел та альтернативних видів палива, раціональне використання природноресурсного потенціалу та покращення екологічного стану регіонів.

За таких умов звертання до ресурсу вторинних енергетичних потенціалів підприємств переробної і харчової промисловості має принципове значення. Їх використання можливе на основі створення замкнутих енергоматеріальних контурів, в яких задіяні потенціали вторинних ресурсів і першоджерел.

Метою дослідження $\epsilon$ аналіз сучасного стану й оцінка перспектив створення замкнутих енергетичних контурів на основі використання вторинних ресурсів середовищ харчової промисловості.

Методи дослідження грунтуються на основі аналізу методик оцінювання вторинних енергетичних потенціалів і феноменологічних узагальнень, запропонованих до використання розробок.

Викладення основних результатів дослідження. Вхідні сировинні потоки харчових виробництв слід оцінювати на основі першоджерел хімічної енергії у формі різних органічних сполук. Завданням харчових технологій $є$ відповідні трансформації і видозміни вказаних потоків з максимально можливим збереженням ï енергетичних потенціалів. Енергоматеріальні перетворення в цих технологіях відбуваються в рамках законів природи і грунтуються на використанні таких різних форм енергії, як хімічна, теплова, механічна, електромагнітна, акустична тощо.

Вторинні енергетичні ресурси на підприємствах різних галузей представлені відпрацьованими потоками повітря, газів, тепловими потенціалами води, пари, напівпродуктів, продукції, потенціалами газонасичених середовищ, стічних вод, відходів, кінетичною енергією технологічних машин в режимах вибігу тощо. У більшості випадків енергетичні втрати $є$ співрозмірними або навіть переважають частку потенціалів першоджерел, які використовуються безпосередньо на технологічні перетворення матеріальних потоків.

Підсилення таких недоліків часто супроводжується необхідністю додаткових витрат, пов'язаних з нейтралізацією потенціалів матеріальних або енергетичних потоків на проміжних або вихідних ділянках виробництв. Наприклад, тепловий потенціал $100 \mathrm{~m}^{3}$ звареного пивного сусла складає близько $35 \cdot 10^{3}$ МДж, 
який під час охолодження передається довкіллю використанням артезіанської води або нейтралізується роботою холодильних установок. Названий потенціал еквівалентний 700 кг газу метану з теплотворною здатністю 49800 кДж/кг.

Технології зброджування цукровмісних середовищ супроводжуються матеріальними втратами $\mathrm{CO}_{2}$, екологічним тиском на довкілля, енергетичними втратами 169 кДж теплової енергії на кожний моль збродженої глюкози, нейтралізація яких також потребує роботи холодильних установок.

Внутрішні енергетичні потенціали теплової та кінетичної енергій циркуляційних контурів газорідинних або рідинних середовищ можуть бути використані для інтенсифікації технологічних процесів за рахунок створення енергетичних імпульсів.

Переробка сировинних потоків супроводжується їх взаємодією з енергетичними потоками 3 поступовими або разовими трансформаціями перших за проявами деструкції або синтезу. Очевидно, що саме енергетичні потоки спрямовують і визначають інтенсивність та розвиток трансформацій. Одним із прикладів останнього є використання технологій високотемпературної короткочасної стерилізації (ВТКС) продукції, яка супроводжується не лише досягненням іiі асептичного стану, а й суттєвим зменшенням руйнувань біологічних компонентів, вітамінів та інших цінних речовин.

Сучасні розробки співробітників кафедри мехатроніки та пакувальної техніки Національного університету харчових технологій у співдружності з спеціалістами промисловості стосуються можливостей інноваційних доповнень існуючих технологій у кількох напрямах.

Напрям перший стосується впливів на перероблювані середовища концентрованих енергетичних потоків. До їх числа відносяться вже визнані дискретноімпульсні технології, пов'язані $з$ тепловим енергетичним накопичуванням середовищ у проявах на основі взаємозв'язків між температурами кипіння їх рідинних фракцій і тисками. Наприклад, екструзійні трансформації в харчових технологіях відповідають цьому випадку і супроводжуються миттєвим пароутворенням рідинної фази в умовах адіабатних процесів з використанням накопиченого енергетичного потенціалу. При цьому важливо, що перебіг таких процесів відбувається в обмеженому часі (до 1 секунди і менше). Це означає, що падіння потужності енергетичного потенціалу має супроводжуватися активним пароутворенням. Останнє викликає механічне руйнування твердої фази аж до клітинного рівня.

В окремих випадках етап спеціального підвищення енергетичного потенціалу може бути відсутнім, якщо початкові параметри середовища дають змогу вакуумуванням перевести їх до стану термодинамічної нерівноваги з усіма наступними етапами. В такому режимі можливо обробляти потік соко-стружкової суміші, яка передається з передошпарювача у дифузійний апарат цукрового заводу; заторну масу пивзаводу перед подаванням іiі у фільтраційний апарат; подрібнену масу овочів, фруктів або ягід перед пресуванням або перед екстракцією тощо. Наслідком таких дій є підвищення виходу цільових компонентів.

Другим важливим напрямком підвищення енергетичних потенціалів середовищ $є$ насичення їх легкорозчинними газами. В технологіях виноробства, виробництва пива, спирту тощо таке насичення є результатом мікробіологічного бродіння, проте використання $\mathrm{CO}_{2}$ у формі носія енергетичного потенціалу цілком придатне і для інших середовищ. Це може стосуватися, наприклад, передпресової підготовки сусла і ягід винограду, подрібнених овочів і фруктів. Для 
підвищення результативності сатурацію середовищ здійснюють за підвищених тисків, оскільки розчинність газів у рідинних середовищах залежить від них і від температури. Зниження останньої розчинність газів збільшує.

Різка розгерметизація насичених рідинних і вологовмістких середовищ має ефекти, подібні до тих, які супроводжують адіабатне кипіння.

На основі цих явищ сформульовані пропозиції щодо інтенсифікації i збільшення виходу цільових речовин у технологіях виноробства, сокодобування, екстракції, у виробництвах пива, кондитерських виробів тощо.

Наведений перелік напрямків підвищення енергетичних потенціалів має своє відображення у формі патентів різних рівнів, однак останні знайшли важливі доповнення. Вони стосуються безпосередньо середовищ, що знаходяться у стані зброджування. Наявність $\mathrm{CO}_{2}$ в середовищах означає наявність енергетичного потенціалу. Окрім того, у середовищах висотою 10-20 м і більше відчутним стає висотний градієнт у концентраціях розчиненого газу. Це стосується циліндро-конічних танків (ЦКТ) для зброджування пива, акратофорів у виробництві шампанського, форфасів пивзаводів, бродильних апаратів спиртової промисловості. Запропоновані до впровадження конструктивні рішення, в яких потенціали розчинених газів використовуються для перемішування, гомогенізації середовищ й активізації зброджування.

Напрямок третій стосується інтенсифікації масообмінних процесів у газорідинних середовищах. Наявність диспергованої газової фази у рідинному середовищі супроводжується виникненням циркуляційних газорідинних контурів. Наслідком їх існування є помітне зменшення утримувальної здатності по газовій фазі й обмеження по інтенсивності масообміну. При цьому левова частка енергетичного потенціалу вхідного газового потоку без користі витрачається на циркуляцію.

Ліквідацію або хоча б обмеження цього недоліку пропонується за рахунок відмови від недетермінованої гідродинаміки циркуляційних контурів і використання спрямованих контурів 3 можливістю швидкоплинної зміни їх напрямків. Такій підхід призводить до чергування прямотоків і протитоків газової і рідинної фаз з помітним підвищенням інтенсивності масообміну.

Додатковий наступний крок в удосконаленні барботажних аераційних систем стосується необхідності суміщення зон утворення міжфазних поверхонь 3 найбільш енергонасиченими зонами. Реалізація цього положення можлива використанням диспергаторов або за рахунок підвищення швидкості контактування газової і рідинної фаз до значень $40 \ldots 45 \mathrm{~m} / \mathrm{c}$.

Перспективним напрямком інтенсифікації масообмінних процесів у газорідинних середовищах визначено зміну тисків в газовому просторі герметичного апарат. За таких умов усі складові диспергованої газової фази відгукуються на зміни тиску пульсаціями, оновленням поверхонь поділу фаз. Це важливо як для випадків малорозчинних, так і для легкорозчинних газів, оскільки деформації газових бульбашок супроводжуються змінами і оновленням газових і рідинних плівок на поверхнях поділу фаз. Теоретичними розробками досягнута можливість оцінювати газорідинні середовища у формі пружних 3 визначенням частот їх власних коливань.

Четвертий напрямок. Енергетичне забезпечення необхідне у всіх технологіях харчових виробництв і стосується змін внутрішніх потенціалів сировинних потоків і одночасно наявності зовнішніх енергетичних потоків. У значній кількості випадків самі матеріальні потоки виконують роль енергоносіїв або для 
цієї ролі застосовують інші матеріальні потоки. Частіше це водяна пара або нагріте чи охолоджене повітря, холодильні агенти термодинамічних циклів холодильних машин, кондиціонерів або теплових насосів, електромагнітні поля, інфрачервоні промені, електричний струм, потоки стиснутого повітря, потоки розчинів тощо. При цьому у більшості створення потоків останнього переліку потребує введення механічної енергії, яка, у свою чергу, є трансформацією хімічної енергії первинних теплоносіїв у ланцюгу перетворень через теплову енергію. Закономірності енергетичних перетворень використовуються в інтересах забезпечення матеріальних потоків, однак у кінцевому результаті можливо побачити надзвичайно нераціональне їх завершення.

Так, повітря, що використовується для аерації пророщуваного солоду, повинне мати показники температури $10^{\circ} \mathrm{C}$ і відносну вологість біля $100 \%$. Очевидно, що досягнення цих показників в різні періоди року потребує кондиціонування 3 відповідними енергетичними витратами. Аерація пророщуваної зернової маси має завданням відведення теплової енергії біологічних перетворень, доставку кисню і відведення утворюваного діоксиду вуглецю.

Величина матеріального потоку повітря повинна бути такою, щоб на виході його температура була близькою до номінальної температури зернової маси $12 \ldots 16^{\circ} \mathrm{C}$. Наведені значення параметрів приводять до висновку про низький коефіцієнт корисної дії такої системи. При цьому нагадаємо, що повітря зовнішнього середовища, яке подається на кондиціонування, може мати температури $-20 \ldots-30^{\circ} \mathrm{C}$ взимку i $+30 \ldots+35^{\circ} \mathrm{C}$ влітку. Саме тому підвищення ККД системи в цілому слід шукати на шляху створення замкнутих або частково замкнутих енергетичних контурів.

Це означає необхідність використання рекуперації та регенерації енергоматеріальних потоків. Проте в кожному випадку необхідно долати певні бар'єри, які до нашого часу стримують використання названих замкнутих контурів. Так у наведеному прикладі аерації зернових середовищ роль своєрідних бар'єрів виконують підвищення концентрації $\mathrm{CO}_{2}$ i зменшення концентрації кисню. Однак температура вихідного потоку продовжує залишатися близькою до номінальної.

Створення замкнутих контурів енергетичного забезпечення $\epsilon$ особливо доцільним і ефективним у випадках, коли в харчових технологіях передбачається теплова обробка з генеруванням вторинної пари. Витрати на регенерацію і наближення параметрів вторинної пари до значень, які дають змогу використати іiї в ролі первинної, супроводжуються коефіцієнтами трансформації $10 \ldots 20$ одиниць і більше. Це означає, що витрачений на регенерацію 1 кДж повертає десятки кДж теплової енергії.

Замкнуті контури енергетичного забезпечення є обов'язковими щодо процесів сушіння, теплової обробки продукції пастеризацією чи стерилізацією, охолодження середовищ. На увагу заслуговує можливість трансформації низькопотенціальних енергетичних потоків у високопотенціальні. Звичайно, що останнє зіставлення $є$ певною мірою умовним, оскільки, наприклад, вода, використана для охолодження бродильних апаратів, може мати температуру близько $+25^{\circ} \mathrm{C}$, що є прийнятним для роботи теплових насосів.

Організація замкнутих контурів енергокористування $\epsilon$ не менш актуальною й енергоефективною в системах охолодження продукції. У зв'язку з цим назвемо одну цифру. Так, на пивзаводі охолодження кожної тонни звареного сусла від 
$98 \ldots 100^{\circ} \mathrm{C}$ до температури бродіння $\left(6 \ldots 12^{\circ} \mathrm{C}\right)$ супроводжується п’ятикратними витратами питної води.

3 метою оцінки співвідношень між енергоматеріальними втратами і можливостями їх обмежень звернемося до особливостей технологій пивоварної галузі. В узагальненому вигляді структура матеріальних втрат пивзаводів наведена на рис. 1, а теплові втрати відображені схемою на рис. 2.

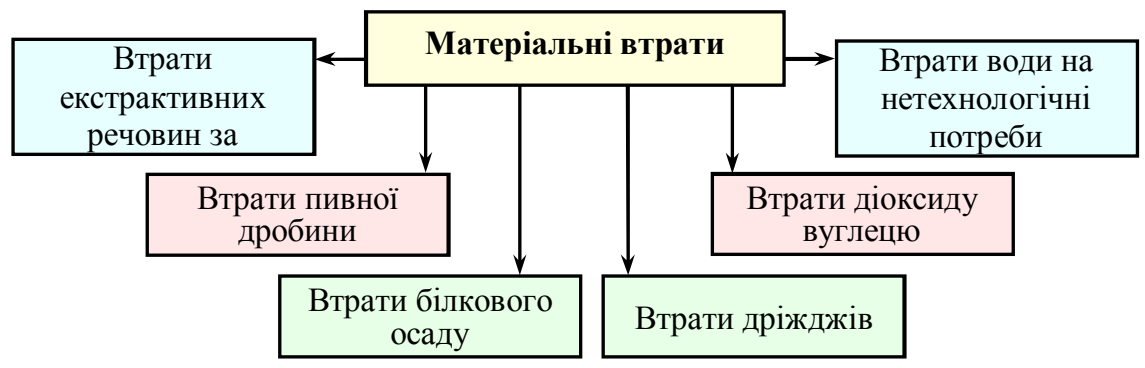

Рис. 1. Структура основних втрат, що стосуються матеріальних та енергетичних потоків пивзаводів

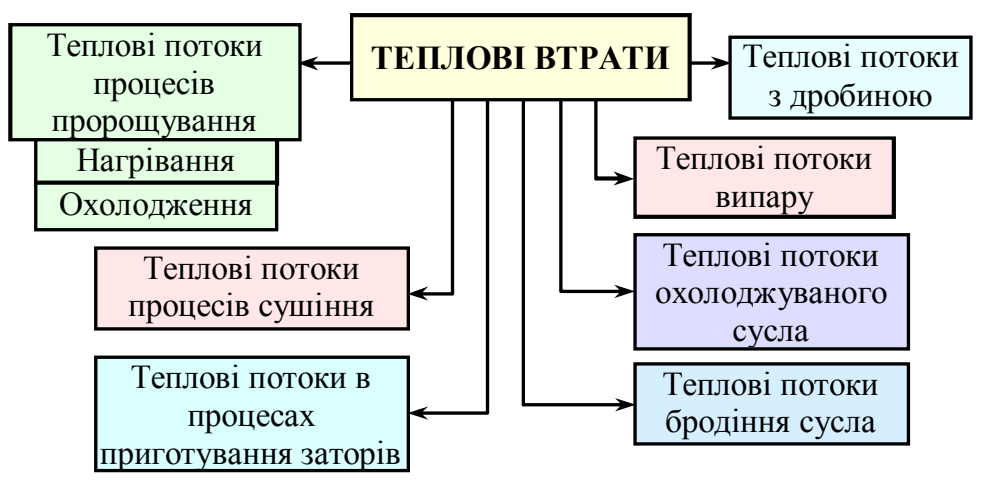

Рис. 2. Структура теплових втрат пивзаводів

Сучасні світові технології, що стосуються матеріальних втрат за позиціями по рис. 1 і теплових втрат за позиціями рис. 2, на високому рівні звертаються до можливостей їх обмежень [1-3]. Однак і за таких умов залишаються значні можливості удосконалення технологій і обладнання виробництва солоду і пива.

Відповідно до наведених структур втрат на підвищену увагу заслуговують як етапи виробництва солоду, так і безпосередньо виробництва пива. В цьому аналізі звернемося до першого з них.

У процесах аерації пророщуваного солоду і його сушінні виникає потреба в організації теплообміну між двома значними потоками газів. Розв'язання такої задачі можливе за рахунок використання двох повітряних калориферів (рис. 3), об'єднаних контуром проміжного теплоносія [4]. Роль останнього може виконувати вода 3 варіаціями безпосереднього використання або з фазовими переходами за рахунок відповідних тисків. В останньому випадку замкнутий енергетичний контур виконує роль теплової труби і забезпечує локальну роль теплообміну між зустрічними газовими потоками або в складі системи для пророщування солоду 
(рис. 4) [5]. В цьому випадку вхідний потік повітря подається на калорифер 1 і в результаті теплообміну з теплоносієм замкнутого контуру 7 отримує термодинамічні параметри, наближені до номінальних, а в калорифері 3 у взаємодії зі зволожувальною камерою 4 досягаються номінальні параметри температури і $100 \%$ відносної вологості, у тому числі за рахунок свіжого повітря і його рекупераційної частини. Підготовлена таким чином суміш подається на аерацію пророщуваного зерна. Відпрацьоване повітря подається на калорифер 6, віддає свій тепловий потенціал проміжному теплоносію і виводиться з системи. Утворення загального замкнутого енергетичного контуру досягається за рахунок додаткового енергоматеріального контуру 7.

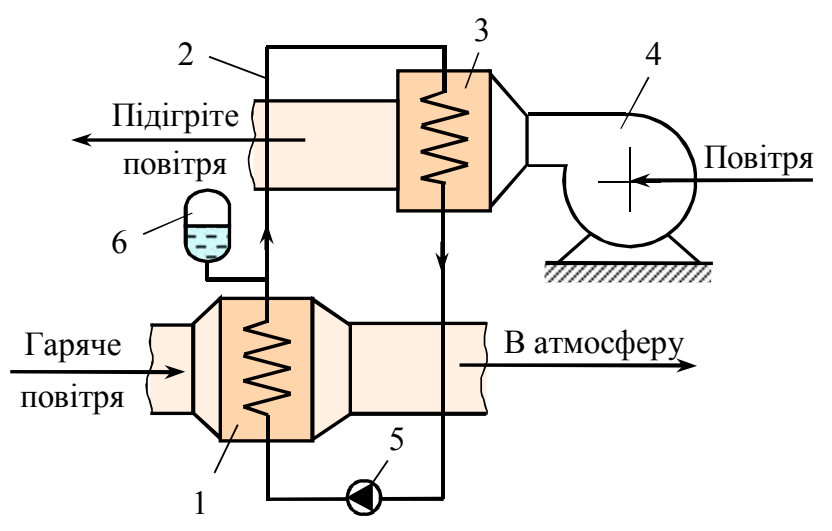

Рис. 3. Схема пристрою для рекуперативного повернення теплової енергії в системах теплообміну між двома газовими потоками (патент 14523 UA): 1, 3 - калорифери;

2 - циркуляційна система проміжного теплоносія; 4 - вентилятор; 5 - насос; 6 - компенсатор гідравлічних ударів і теплового розширення проміжного теплоносія

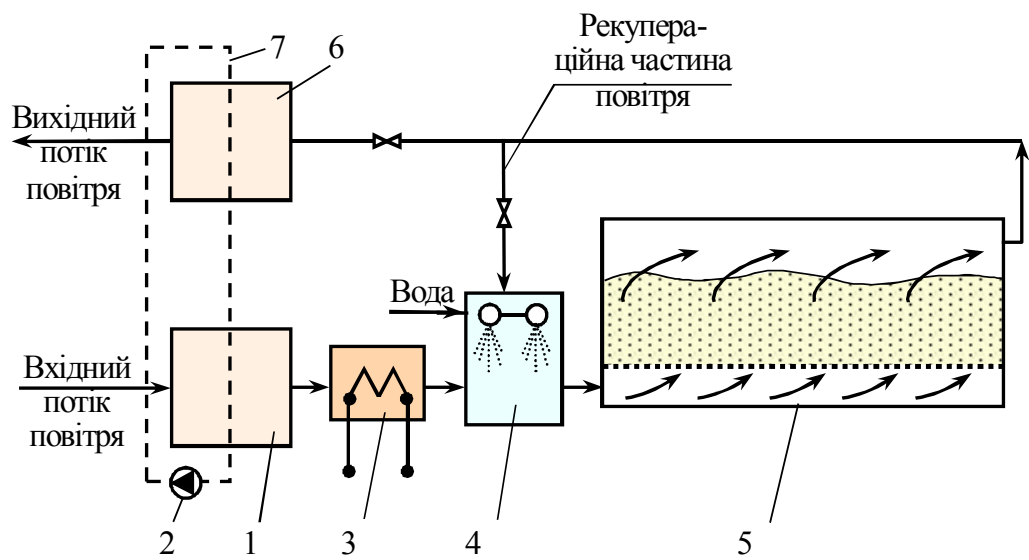

Рис. 4. Пристрій для пророщування солоду (патент 65478 України):

1 - калорифер вхідного потоку повітря; 2 - насос; 3 - калорифер; 4 - зволожувальна камера; 5 - солодовирощувальний барабан; 6 - калорифер вихідного потоку повітря 7 - система гідравлічного зв'язку калориферів, температурної підготовки вхідного потоку

Обмеження кількісної частини рекупераційного потоку повітря в системах аерації пророщуваного зерна пояснюється наявністю в ньому діоксиду вуглецю. 
Зниження частки останнього сприяє можливості збільшення рециркуляційного потоку й ефективності системи. Цей напрямок відображується патентом України 58827, за яким камера кондиціювання повітря виконана 3 зоною десорбції вуглецю $з$ рекупераційної частини повітря (рис. 5) [6]. Рециркуляційна частина повітря 3 надходить в зону десорбції 7, контактує з водою, яка розпилюється форсунками 6 і яка абсорбує $\mathrm{CO}_{2}$. Змішані в кінці зони десорбції потоки свіжого і рециркуляційного повітря подаються в підситовий простір-повітропровод. Контур у цьому випадку має бути напівзамкнутим у зв'язку зі зниженням концентрації кисню у рециркуляційній частині повітря.

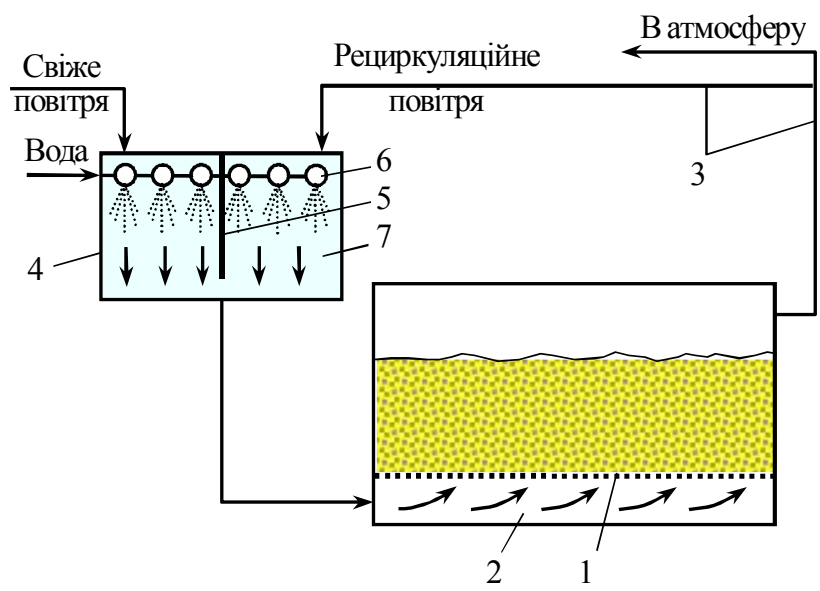

Рис. 5. Пристрій для пророщування зерна (патент 58827 України): 1 - несправжнє ситове днище; 2 - підситовий простір-повітропровод; 3 - система відбору рециркуляційної частини повітря; 4 - камера кондиціювання повітря; 5 - вертикальна перегородка; 6 - форсунки 7 - зона десорбції діоксиду вуглецю з рециркуляційної частини повітря

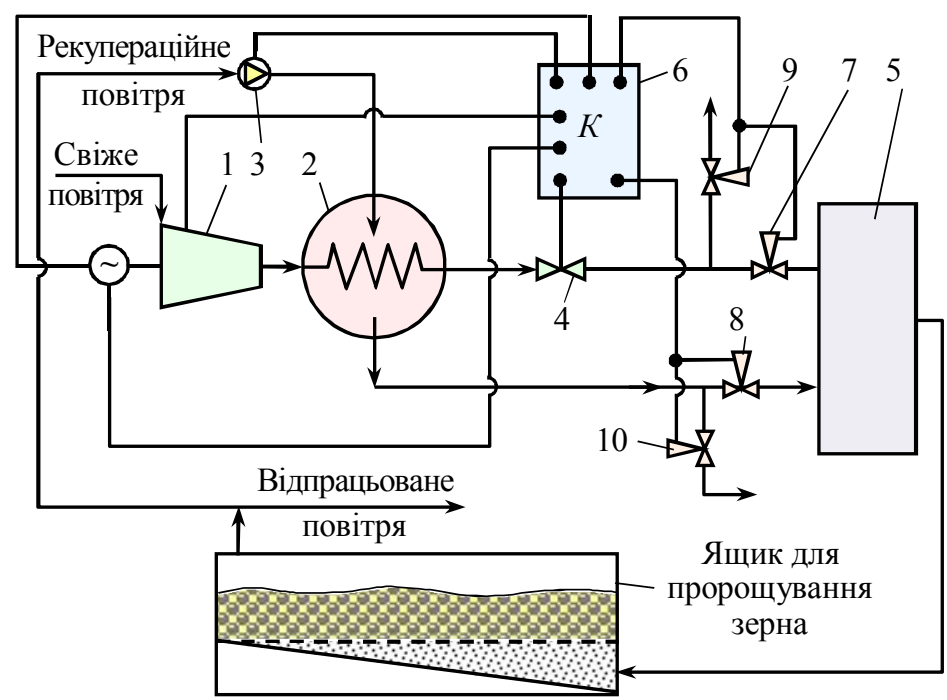

Рис. 6. Схема системи підготовки аераційних повітряних потоків при пророщуванні зерна (патент 58899 України) 
Термодинамічні протиріччя процесів аерації пророщуваного зерна пов'язані 3 добовими і сезонними змінами температур і вологості повітря. В розробці за патентом України 58899 [7] ставиться завдання обмеження таких негативних зовнішніх впливів. На рис. 6 наведено систему підготовки аераційних повітряних потоків. Свіже повітря стискається у турбокомпресорі 1 з регульованою частотою обертання ротора 3 підвищенням його енергетичного потенціалу i подається на калорифер 2, в якому через теплообмінну поверхню віддає частину теплового потенціалу рекуперативній частині повітря від вентилятора 3. Стиснуте повітря з калорифера 2 в дроселі 4 знижує свій тиск та температуру i, проходячи через регулювальний вентиль 7, потрапляє у змішувач потоків 5. Сюди ж через регулювальний вентиль 8 підводиться рекупераційний потік повітря. Регулювання величин повітряних потоків здійснюється контролером 6, а їх надлишки регулювальним вентилем 9 виводяться з системи.

Ящик для

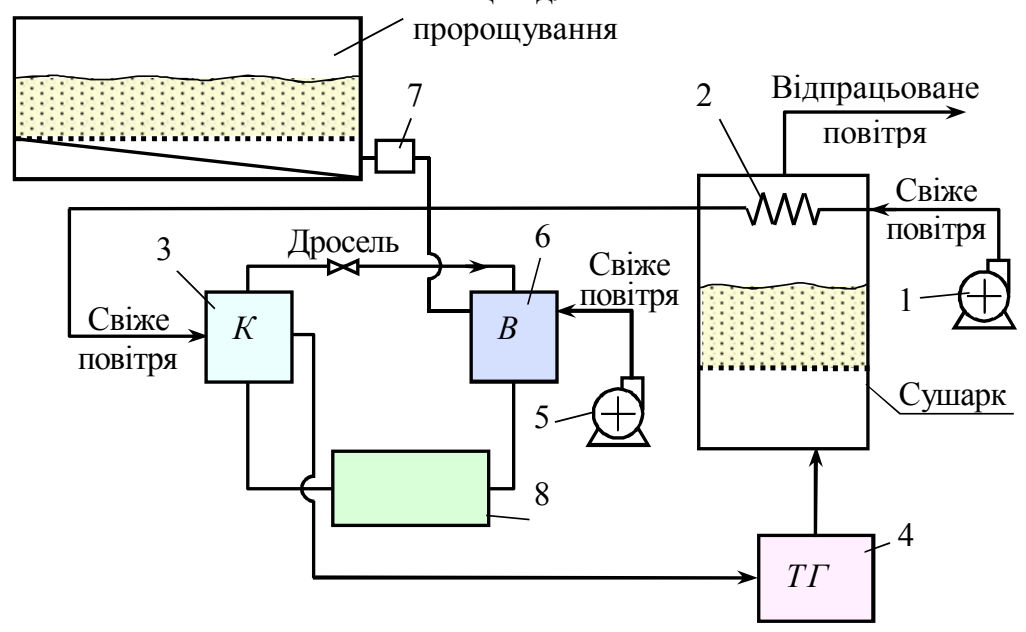

Рис. 7. Схема до комплексного використання теплового насоса у виробництві солоду:

1, 5 - вентилятори; 2 - теплообмінний апарат; 3 - конденсатор; 4 - теплогенератор; 6 - випарник; 7 - розпилювач води; 8 - компресор

Процеси пророщування зернової маси будуються як неперервні з циклом обробки, наближеним до 7...8 діб. У випадку неперервної роботи сушарки існує можливість синхронізації їх роботи. При цьому термодинамічні трансформації 3 вхідними повітряними потоками мають особливі спрямування. Так, повітря, що подається до теплогенератора сушарки (рис. 7) [8], завжди доцільно догрівати, тоді як аераційний потік щодо температури варіюється, оскільки остання має бути стабілізованою на рівні $12^{\circ} \mathrm{C}$. Тоді за весняно-літнього сезону можливим $\epsilon$ поєднання процесів аерації і сушіння застосуванням теплового насоса з утворенням напівконтурів підготовки повітря для сушарки і для аерації та замкнутого контуру теплового насоса.

Система працює таким чином: свіже повітря вентилятором 1 подається в теплообмінний апарат 2, змонтований в контакті з відпрацьованим потоком повітря сушарки, підігрівається і подається у конденсатор 3 теплового насоса 3 додатковим підвищенням теплового потенціалу. Таке підвищення температури у цих двох взаємодіях призводить до зниження його відносної вологості, а досяг- 
нення необхідних кінцевих параметрів сушильного агента відбувається у теплогенераторі 4. Після контактування 3 теплообмінною поверхнею у теплообміннику 2 потік сушильного агента скидається у довкілля.

Вентилятор 5 подає свіже повітря у міжтрубний об'єм випарника 6, охолоджується 3 підвищенням відносної вологості і через розпилювач повітря подається у підситовий простір ящика для пророщування солоду.

Сполучення двох напівзамкнутих контурів 3 контуром теплового насоса супроводжується подвійним ефектом у формі номінальної температури аераційного потоку повітря і повітря, що подається на теплогенератор, 3 доведенням його параметрів до рівня сушильного агента.

Висновки. Виконаний аналіз стану інноваційних розробок щодо використання вторинних енергоматеріальних ресурсів на підприємствах харчової промисловості дає змогу зробити такі висновки:

1. Логістичну побудову енергозбереження в технологіях з дискретними режимами роботи доцільно організовувати в рециркуляційних режимах матеріальних потоків енергоносіїв.

2. Показано можливість і доцільність створення замкнутих контурів енергокористування на основі трансформацій вторинних енергетичних ресурсів для більшості харчових технологій.

3. Найбільші рівні трансформацій енергетичних потоків пов'язані з фазовими переходами та ізоентальпійним процесами. Останнє означає доцільність створення замкнутих енергетичних контурів.

У результаті проведеного дослідження запропоновано схеми апаратурного забезпечення для стабілізації термодинамічних параметрів в процесах пророщування і сушіння солоду.

\section{ЛIТЕРАТУРА}

1. Кунце В. Технология солода и пива / В. Кунце. - С.-Пб. : Профессия, 2001. - 912 с.

2. Енергетичні трансформації і енергозбереження в харчових технологіях: монографія / А.І. Соколенко, А.А. Мазаракі, В.А. Піддубний та ін. - К. : Фенікс, 2012. - 484 с.

3. Інтенсифікація тепло- масообмінних процесів у харчових технологіях: монографія / за ред. д-ра техн. наук, проф. А.І. Соколенка. - К. : Фенікс, 2011. — 536 с.

4. Пристрій для рекуперативного повернення теплової енергії в системах теплообміну між двома газовими потоками: пат. на корисну модель 14523 Україна: МПК F25B 1/10 (2006.01) / Соколенко А.І., Шевченко О.Ю., Рєзнік В.Г., Піддубний В.А.; власник НУХТ. № u200511369; заявл. 30.11.2005; опубл. 15.05.2006, Бюл. № 5 .

5. Пристрій для пророщування солоду: пат. на корисну модель 65478 Україна: МПК С12С 1/00 / Піддубний В.А.; власник НУХТ. № u201105542; заявл. 29.04.2011; опубл. 12.12.2011, Бюл. № 23.

6. Пристрій для пророщування зерна: деклар. пат. на винахід 58827 Україна: МПК С12C 1/00 / Соколенко А.І., Українець А.І., Яровий В.Л., Шевченко О.Ю., Піддубний В.А.; власник НУХТ. № 2002118775; заявл. 05.11.2002; опубл. 15.08.2003, Бюл. № 8.

7. Система підготовки аераційних повітряних потоків при пророщуванні зерна: пат. на корисну модель 58899 Україна: МПК F25B 1/100 (2006.01) / Соколенко А.І., Шевченко О.Ю., Піддубний В.А., Максименко І.Ф., Шевченко А.О.; власник НУХТ. № u201012391; заявл. 20.10.2010; опубл. 26.04.2011, Бюл. № 8 .

8. Система рекуперації енергетичних потоків у виробництві солоду: пат. на корисну модель 15647 Україна: МПК С12C 7/00, F25B 1/00 / Соколенко А.І., Шевченко О.Ю., Бут С.А., Піддубний В.А., Рєзнік В.Г.; власник НУХТ. № u200512657; заявл. 27.12.2005; опубл. 17.07.2006, Бюл. № 7. 


\title{
ПРЕДЛОЖЕНИЯ К ИСПОЛЬЗОВАНИЮ ЗАМКНУТЫХ ЕНЕРГОМАТЕРИАЛЬНИХ КОНТУРОВ
}

\author{
А.И. Соколенко, К.В. Васильковский, А.И. Степанец, М.И. Юхно \\ Национальный университет пищевых технологий
}

Статья касается физических и термодинамических основ для создания контуров замкнутого энергосбережения в пищевых технологиях. Приведена инфрормация о нетрадиционных подходах в оценках возможностей использования вторичных энергетических ресурсов в четырех направлениях, а именно: в направлении воздействия на перерабатываемые среды с концентрированными энергетическими потоками повышением энергетических потенциалов сред за счет насыщения их легкорастворимыми газами; интенсифрикации массообменных процессов в газожидкостных средах; комбинаций изменений внутренних потенциалов сред и внешних энергетических потоков, с сочетанием процессов рекуперации и регенерации. На примере пивоваренной отрасли приведена структура материальных и энергетических потерь и примеры синтезу замкнутых энергетических контуров на этапе производства солода, показаны возможности и целесообразность трансформаций вторичных энергетических ресурсов для большинства пищевых технологий.

Ключевые слова: замкнутые контуры, массообменных процессы, энергетический потенциал, технология, промышленность, вторичный ресурс, схема, аппарат. 


\section{ДО ВІДОМА АВТОРІВ}

\section{Шановні колеги!}

Редакційна колегія журналу «Харчова промисловість» запрошує вас до публікації наукових праць.

Засновник і видавець журналу: Національний університет харчових технологій.

Журнал затверджений наказом МОН України (постанова № 241 від 09.03.2016) як наукове видання з технічних наук.

У журналі висвітлюються результати науково-дослідних робіт 3 технології харчових продуктів, хімічних, біохімічних, мікробіологічних процесів, апаратів, обладнання, автоматизації харчових виробництв та економіки харчової промисловості.

Обсяг статей - до 10 машинописних аркушів (до 10000 друкованих знаків).

\section{ВИМОГИ ДО ОФОРМЛЕННЯ СТАТЕЙ}

Статті мають бути підготовлені з урахуванням Постанови Президії ВАК України № 7-05/6 «Про підвищення вимог до фахових видань, внесених до переліків ВАК України». Друкуються наукові статті, які мають такі необхідні елементи: постановка проблеми у загальному вигляді та іiі зв'язок із важливими науковими чи практичними завданнями; аналіз останніх досліджень i публікацій, в яких започатковано розв'язання певної проблеми і на які спирається автор; виділення не вирішених раніше частин загальної проблеми, яким присвячується означена стаття; формулювання цілей статті (постановка завдання); виклад основного матеріалу дослідження 3 повним обгрунтуванням отриманих наукових результатів; висновки 3 цього дослідження і перспективи подальших розвідок у цьому напрямі.

До публікації приймаються не публіковані раніше статті, що містять результати фундаментальних теоретичних розробок та найзначніших прикладних досліджень викладачів, наукових співробітників, докторантів, аспірантів і студентів. Усі статті підлягають обов'язковому рецензуванню провідними спеціалістами у відповідній галузі харчових технологій, яких призначає науковий редактор журналу.

Рукопис статті надсилається у двох примірниках, українською мовою, включаючи таблиці, рисунки, список літератури.

Статті подаються у вигляді вичитаних роздруківок на папері формату A4 (поля з усіх сторін по 2 см, шрифт Arial або Time New Roman, кегль 14, інтервал 1,5) та електронної версії (редактор Microsoft Word) на електронному носії. На електронному носіїі не повинно бути інших версій та інших статей, у тексті статті - порожніх рядків. Між словами допускається лише один пробіл. Усі сторінки тексту мають бути пронумеровані.

На першій сторінці наводяться: у лівому верхньому куті - шифр УДК (напівжирним шрифтом), нижче ініціали і прізвища авторів (напівжирним шрифтом), наукові ступені авторів, назва установи, де працює автор; далі - назва статті великими напівжирними літерами, під назвою анотація українською мовою 3 ключовими словами (5-6 слів/ключових словосполучень) набрана світлим курсивом; фраза «Ключові слова» — напівжирним шрифтом.

У кінці першої сторінки, під короткою рискою, ставиться знак авторського права, ініціали, прізвища авторів, рік.

Матеріали, представлені у статті, мають буги розділені на основні змістові розділи, такі як: постановка проблеми, огляд літератураи, мета досліджень, матеріали та методи, результати досліджень, висновки. Кожен із наведених розділів статті починається з нового абзацу («Постановка проблеми», «Огляд літератури», «Мета досліджень», «Матеріали і методи», «Результати досліджень», «Висновки» - напівжирним курсивом).

Після тексту статті в алфавітному або порядку згадування в тексті наводиться список літературних джерел (кожне джерело 3 абзацу). Бібліографічні описи оформляються згідно 3 ДСТУ ГОСТ 7.1:2006 «Система стандартів 3 інформації, бібліотечної та видавничої справи. Бібліографічний запис. Бібліографічний опис. Загальні вимоги та правила складання». У тексті цитоване джерело позначається у квадратних дужках цифрою, під якою воно стоїть у списку літератури. Бібліографічний опис подається мовою видання. Не допускається посилання на неопубліковані матеріали. У переліку джерел мають переважати посилання на роботи останніх років.

Прізвища зарубіжних авторів у тексті статті треба наводити в українській транскрипції. 
Після списку літератури наводяться: анотація та ключові слова російською мовою; ініціали і прізвища авторів, назва статті великими напівжирними літерами, анотація та ключові слова (Summary) англійською мовою (розмір анотації не менше 1800 знаків, має містити коротку інформацію по кожному із основних змістових розділів); фрази «Ключевые слова» та «Кеу words» напівжирним шрифтом.

Усі анотації мають містити коротку інформацію щодо об'єкта та методик досліджень 3 наведенням основних результатів роботи та рекомендаціями щодо сфери їх застосування.

Після тексту анотацій та ключових слів наводиться фраза «Одержана редколегією (дата)» (набраним світлим курсивом). За дату одержання статті вважають дату надходження їі до редакції.

Роздрукований варіант статті підписують усі автори.

У разі одержання статті, оформленої з порушенням запропонованих вимог, редакція статтю не реєструє. За необхідності доопрацювання статті відповідно до зауважень рецензента авторам направляється екземпляр рукопису, який разом із рецензією, відповіддю рецензентові, двома екземплярами виправленої статті та електронним носієм з виправленим текстом слід повернути до редакції.

Таблиці виконувати у Microsoft Office Word в форматі DOC. Кожна таблиця повинна мати тематичний заголовок, набраний напівжирним шрифтом, і порядковий номер (без знака №), якщо таблиць кілька. Якщо таблиця одна, то дається тільки заголовок (без слова «Таблиця»). Слово «Таблиця» і номер - курсивним шрифтом, заголовок - напівжирним. Таблиці мають бути закритими - 3 боковими, нижньою і горизонтальними лінійками у полі таблиці.

Ілюстрації мають бути виконані ретельно, в програмі CorelDraw або будь-якому іншому графічному редакторі, на білому папері й розміщені в тексті та в окремих файлах (формати CDR, TIF, JPG; роздільна здатність не менше 300 dpi).

Фотографії друкуються лише у разі крайньої потреби, вони мають бути чіткими, контрастними, виконаними на білому фотопапері, розмірами $6 \times 9 \mathrm{~cm}$.

Підписи до рисунків набираються на окремій сторінці або безпосередньо під рисунками прямим шрифтом.

Повторення одних і тих самих даних у тексті, таблицях і на рисунках не допускаються.

Формули вставляються прямо в текст за допомогою редактора формул. Нумерація формул арабськими цифрами у круглих дужках біля правого поля сторінки.

Використовувані в статті фізичні, хімічні, технічні та математичні терміни, одиниці фізичних величин та умовні позначення мають бути загальноприйнятими. Скорочення позначень одиниць фізичних величин мають відповідати Міжнародній системі одиниць (SI).

До статей додаються: виписка 3 протоколу засідання кафедри (підрозділу) з рекомендацією роботи до друку; відомості про авторів (прізвище, повне ім'я та по батькові, науковий ступінь, місце роботи, номери контактних телефонів, адреса), кафедральний висновок/експертний висновок (для статей сторонніх організацій), заяву з підписами автора(-ів) про те, що надіслана стаття раніше не друкувалася і не подана до будь-яких інших видань

Головний редактор журналу: доктор технічних наук, професор Анатолій Іванович Соколенко.

Відповідальний секретар журналу: кандидат технічних наук, доцент Сергій Володимирович Токарчук.

Контактні телефони: міський - (044) 287-92-45, внутрішній - 92-45

E-mail: tmipt_xp@ukr.net 


\title{
ХАРЧОВА ПРОМИСЛОВІСТЬ
}

\author{
Науковий журнал
}

№ 23

Журнал «Харчова промисловість» затверджений наказом МОН України (постанова № 241 від 09.03.2016) як наукове видання з технічних наук. Реєстаційне свідоцтво: серія КВ № 6890 від 23.01.2003.

Засновник і видавець: Національний університет харчових технологій.

Журнал $є$ продовженням міжвідомчого тематичного збірника «Харчова промисловість», заснованого в 1965 р. Виходить двічі на рік.

\section{Статті друкуються в авторській редакції.}

Відповідальний редактор журналу: А.І. Соколенко

Відповідальний секретар: С.В. Токарчук

Комп'ютерна верстка: А.В. Стамбол

Підп. до друку 22.06 .2018 р. Формат 70 × 100/16.

Гарнітура TimesNewRoman. Друк цифровий.

Ум. друк. арк. 11,45. Обл.-вид. арк. 12,32.

Наклад 100 прим. Вид. № 07/16. Зам. № 23-16

НУХТ 01601 Київ-33, вул. Володимирська, 68 Свідоцтво про реєстрацію серія ДК № 1786 від 18.05.2004 